Historic, archived document

Do not assume content reflects current scientific knowledge, policies, or practices. 



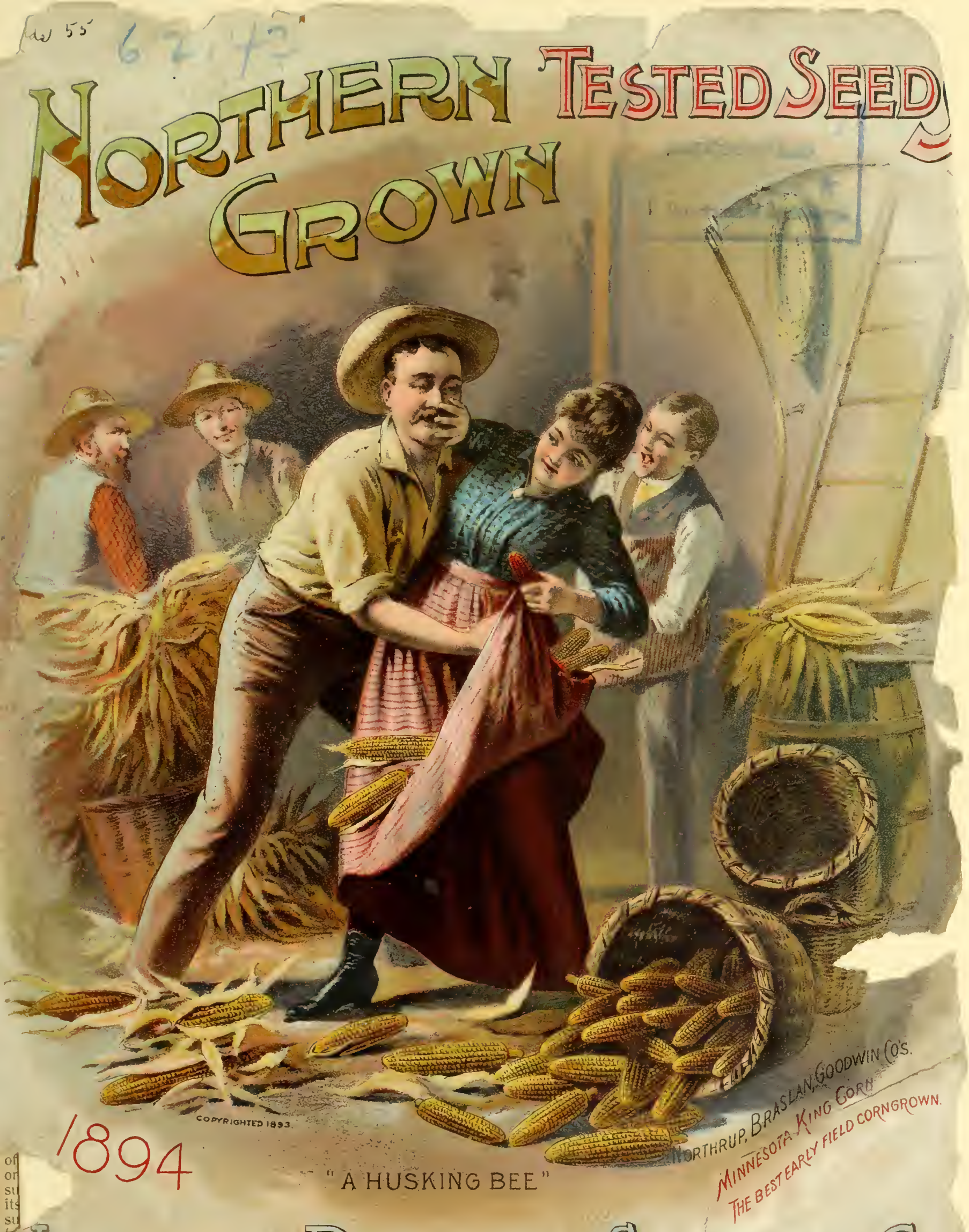
N
(2)mpip

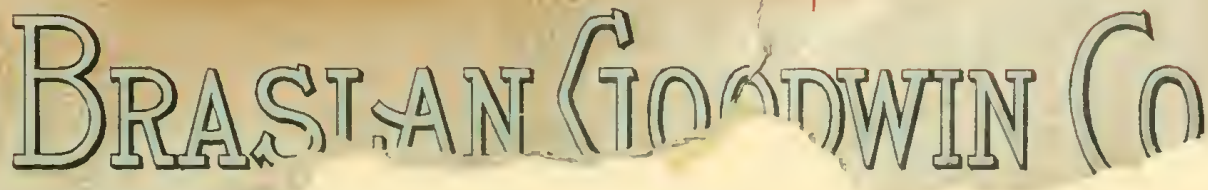 $10 \& 12$ BRIDGE? 


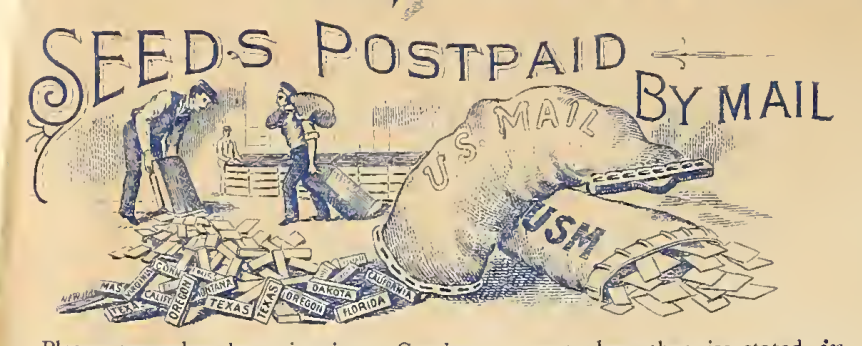

Please remember that prices in our Catalogne, except when otherwise stated, inche prepayment of postage by us on ail Seeds ordered by the packet, ounce, pound, pint or queart; also on plants and Bulbs.

Deduct \& cents per pound from post-paid prices on Seeds ordered scnt by express
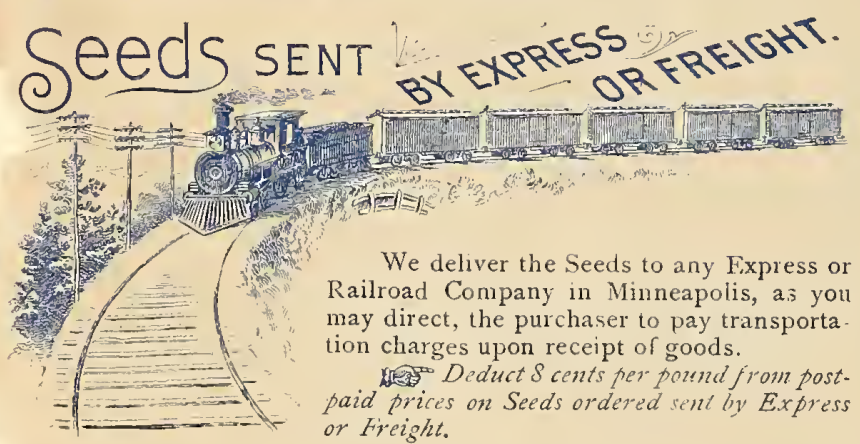

We deliver the Seeds to any Express or
Railroad Company in Minneapolis, as you
may direct, the purchaser to pay transporta-
ion charges upon receipt of goods.
paid prices on Seeds ordered sent by Express
or Freight.

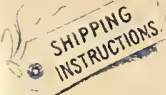

When possible, give full shipping instructions. In the absence of these particulars, we will use our best judgment.

DiscounT on Seeds by the Packet.

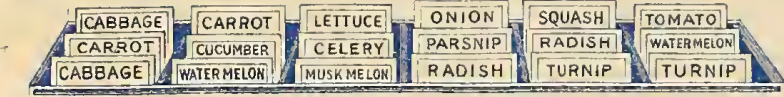
On all orders for Seeds in packets, the purchaser may select 30 cents worth extra for each
$\$ 1.00$ sent us. This discount applies only on A Seeds in packets, and cannot be allowed on Seeds by weight or measure, collections, bulbs or plants.

SPECIAL Market Gardeners, Truckers, and Clubs - SPECIAL. who buy Seeds in large quantities will save money TO LARGE by witing us for special prices. Make out your list
PURCHASERS FURCHASERS.; of requirements from the cataiogue, and send it to us. We will attach prices and return for your approval. 44s. Always glad to give estimates or information.

\section{VEGETABLE and FLOWER SEEDS}

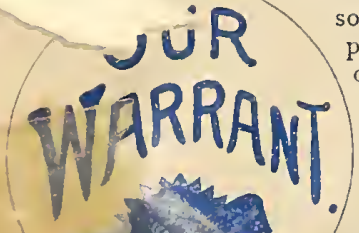

sold from this Catalogue are warranted to prove of strong growth and of satisfactory quality and purity, in so far:- - that, should the contrary prove the case, through any defect in the seed, we will refill the order for such defective seed free of charge, or refund the money paid us for it. GRASS and FIELD SEEDS.- With our improved machinery we are enabled to clean these seeds so thoroughly that we sell them on the following conditions: If upon arrival and prompt test they do not A develop a hirh percentage of growth, or fail to prove of satisfactory purity under nicroscopic examination, they are to be returned at our expense.

Beyond these plainly expressed innditions, we give no warrant whatever, as the outcome of a crop is beyond human control; but as these are the strongest warran's made by any Seed House, they should satisfy the most careful purchaser of the confidence we have in our ability to supply good Seeds.
NO GHARGE FORPACKINGN SHIPPING

\author{
Ful( We make no charge for bags, barrels \\ (con or baskets containing goods sold at catalogue \\ prices, unless by special agreement.
}

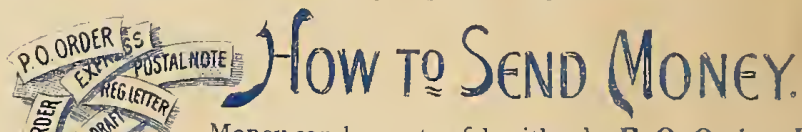

क्ञा aney can be sent safely either by P. O. Order, B Draft, Express Order, Registered Letter or Posta. Note. If your order amounts to $\$$ I.00 or more, always senc by one of the above methods. Postage Stamps receivec the same as cash. Every Postmaster is obliged, upon the paymen of 8 cents, to register a letter. You will then receive our receipt for the letter by return mail.

\section{- Durchiasing BY EXPRESS}

Express Offices have now purchaising departments in all their offices. If you wish to order goods from us to be sen by express, ask for a purchasing order blank at any Expres: Office, and it will be supplied and forwarded without extra charge, other than the usual rates for returning goods.

\section{When \\ YOU ORDER}

dan't farget to give

$$
\text { fIDDRESS. }
$$

\section{THIS IS VERY IMPORTANT.}

\section{SIGH YOUR HAME AKD ADDRESS,}

Many orders reach us every season in which the fair pr Name or Post-office Address is lacking. It is of course be igno impossible for us to fill these orders until they arif lor such h identified.

$$
\text { GS ORDER EARLY }
$$

Customers, by purchasing their Seeds early, w be sure and have them on hand when wanted. Th heaviest rush in the Seed business occurs during th months of March and April, and while we at all tim endeavor to fill orders promptly and accurately, it w accommodate us and greatly relieve our employo having the orders in hand at as early a date sible. It will also insure to our patrons grem curacy and better service generally.

Addiless

$$
\text { (5) }
$$$$
\text { D) A SLAN, }
$$

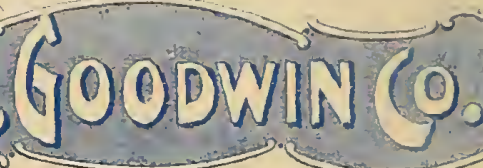

INNESOTA. 


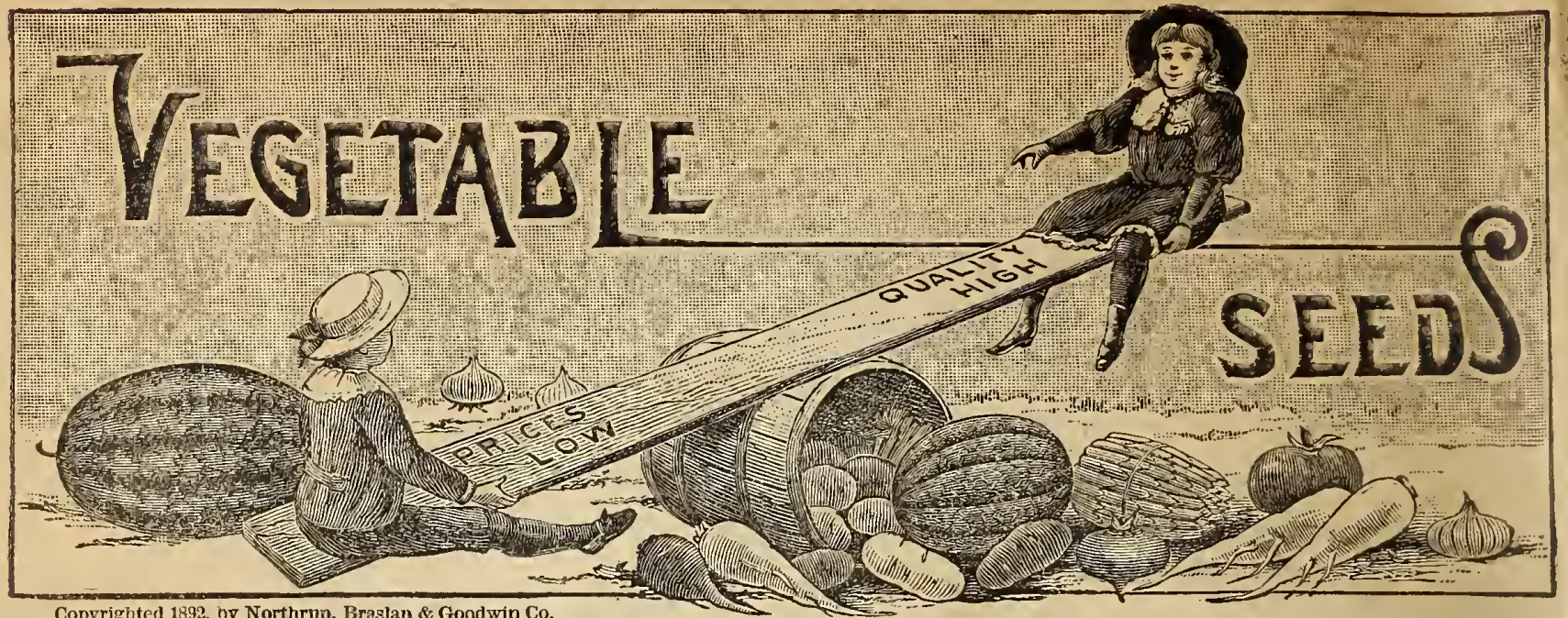

IN YOUR OWN INTEREST. Please note, that our prices, except where otherwise goods are to be sent by Express or Freight, at Purchaser's Expense, 8 cts. per lb. sliould be deducted.

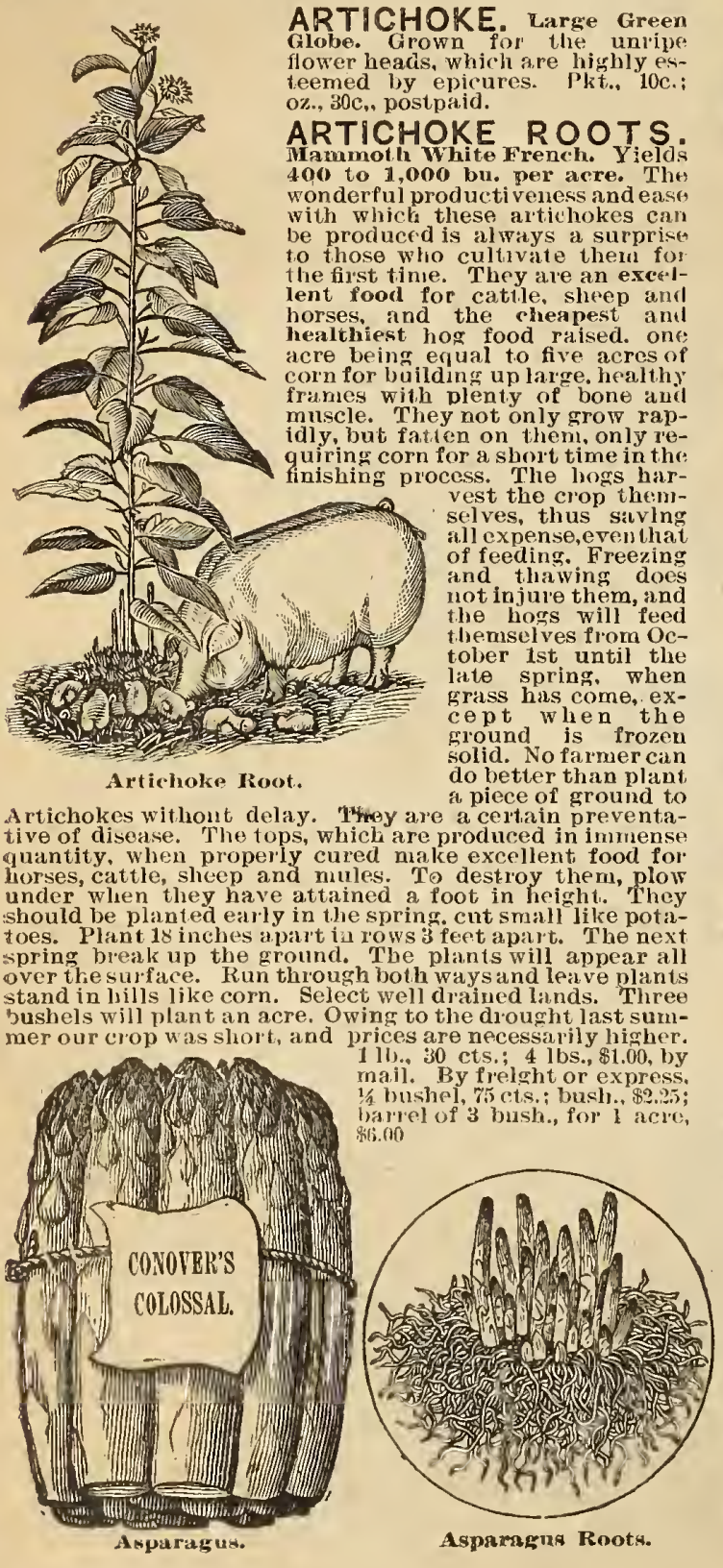

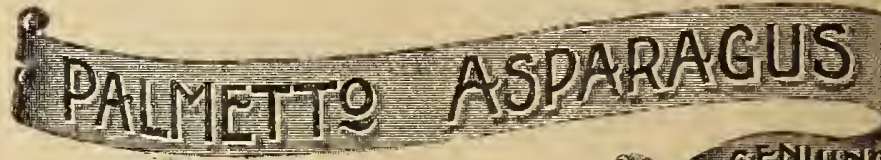

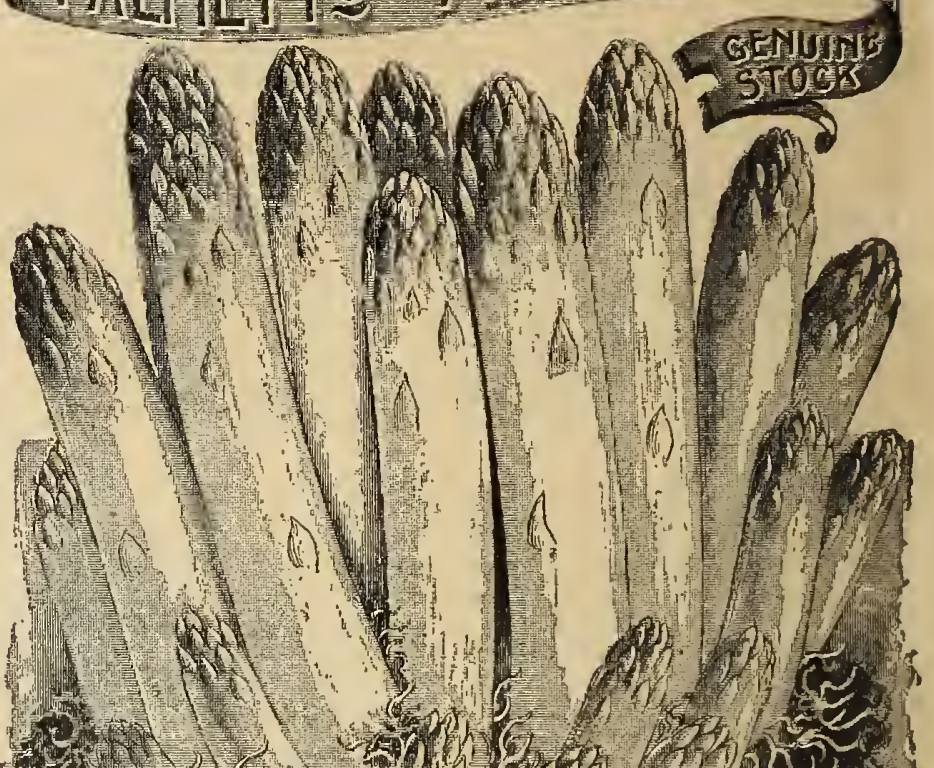

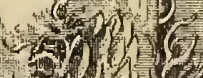

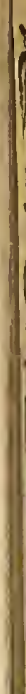


BEANS. Our sales of GARDEN VARIETIES for $189: 3$ were $9,18(;$ I3ushels. This quantity would plant in the neighborhood of $(\mathbf{i , 0 0 0}$ ACRES. A fair average yield of lods would be about 300 bushels to the acre, or ONE MILLION, E:(iHT HUNDRED THOUSAND $(1, \$(M),(O)())$ BUSHELS; worth, at Sixty Cents a bushel, something over ONI: MILIION DOLI.ARS. This DOES NOT INCI.UIDE: [IELD) IBEANS, raised for use in the dried state.

\section{EARLEST}

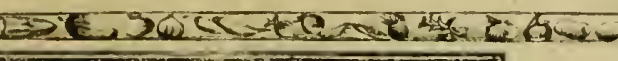
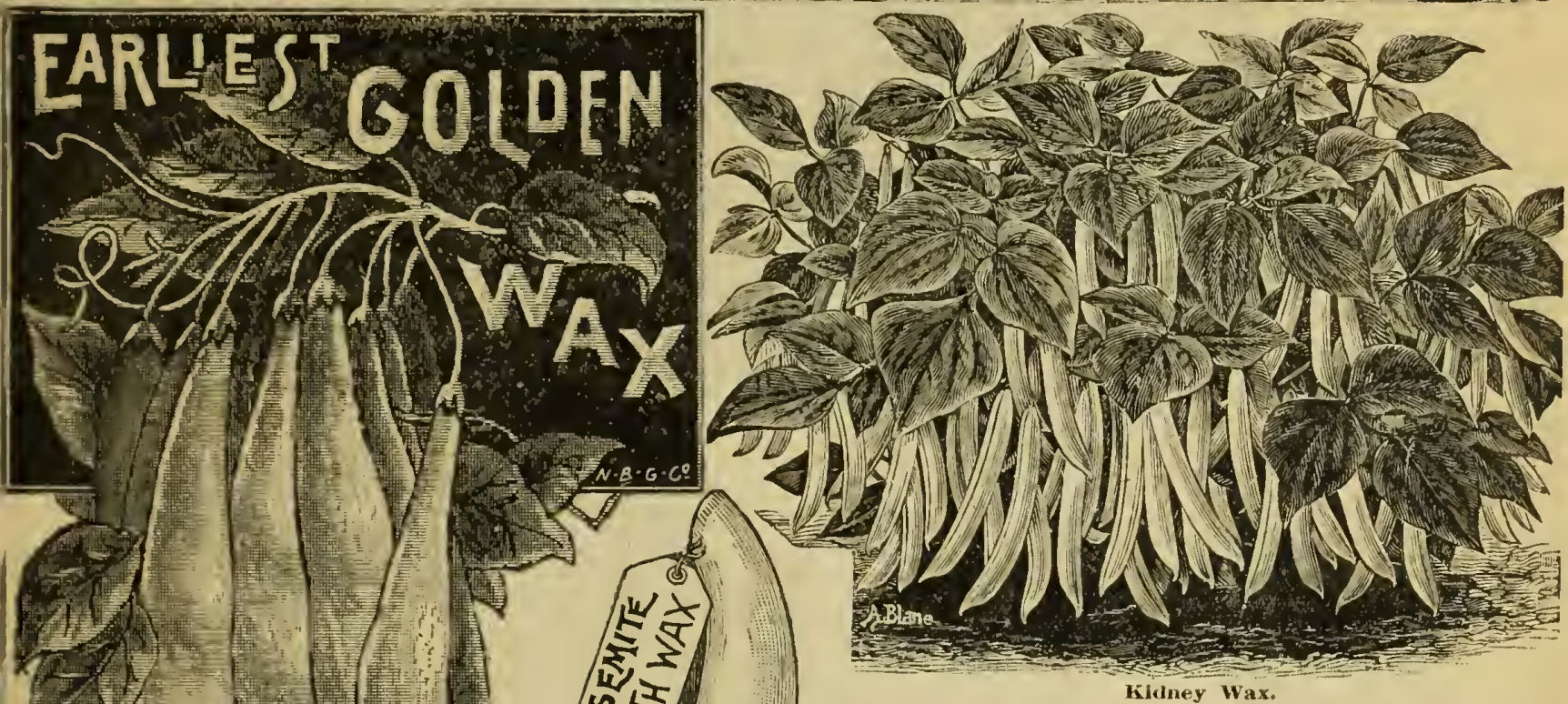

KIDNEY WAX. of reddish purple more or less visible, and a distinct kidney destined to become a leadiug sntap bean, as well is a strongly en-
dorsed winter shelled sort. Pkt.. 5 ets.; 4 t., 60 et s. postpaid. By

DWARF BLACK WAX.
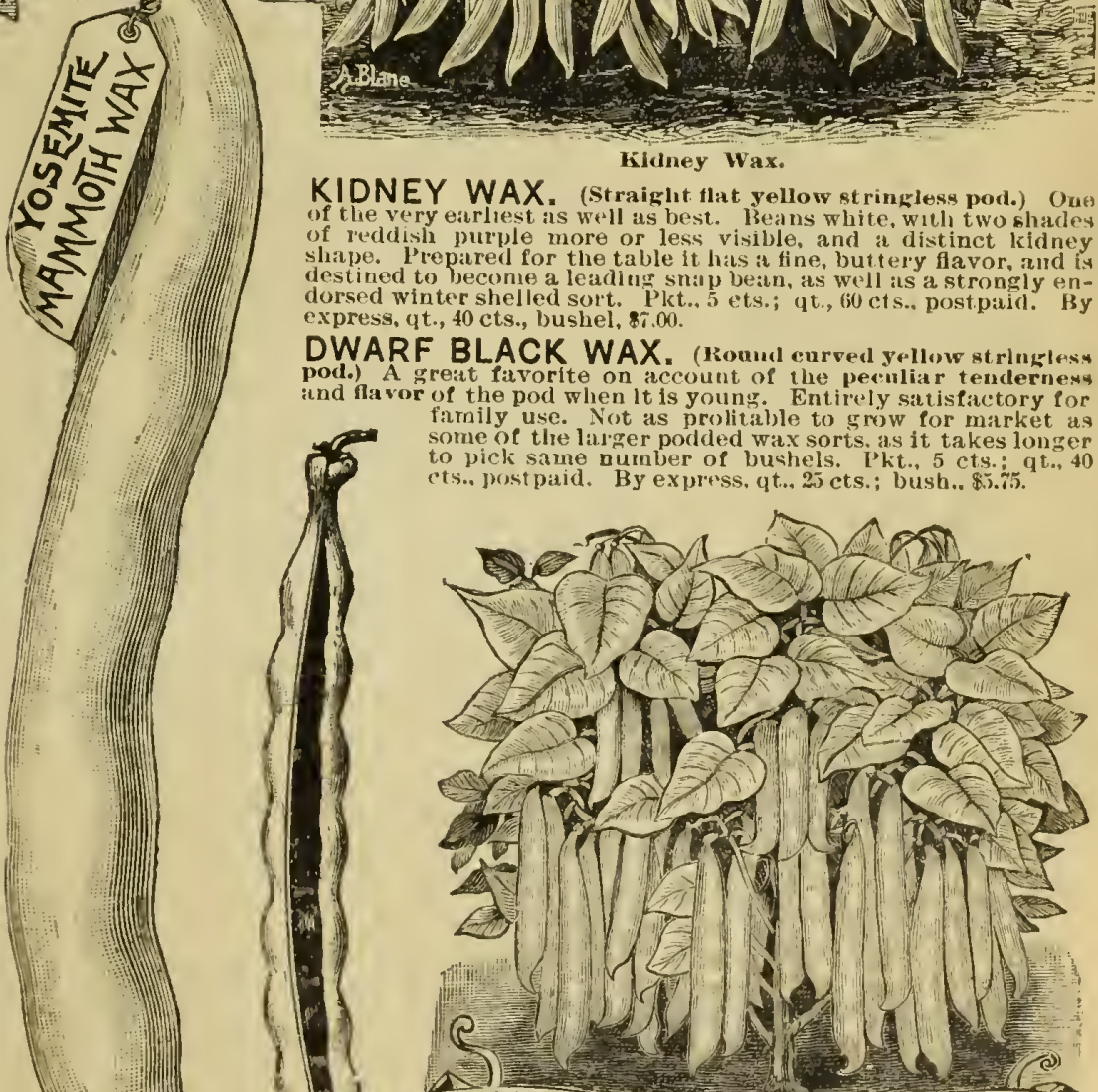

EARLIEST GOLDEN WAX. Stral'5h, flat yellow. Al rimglosw pollo) This varjuly hardly need ies his ol of execllent quality. Our stock is caresully se

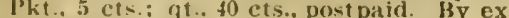


BEANS.-Dwarf Varieties for the Garden.

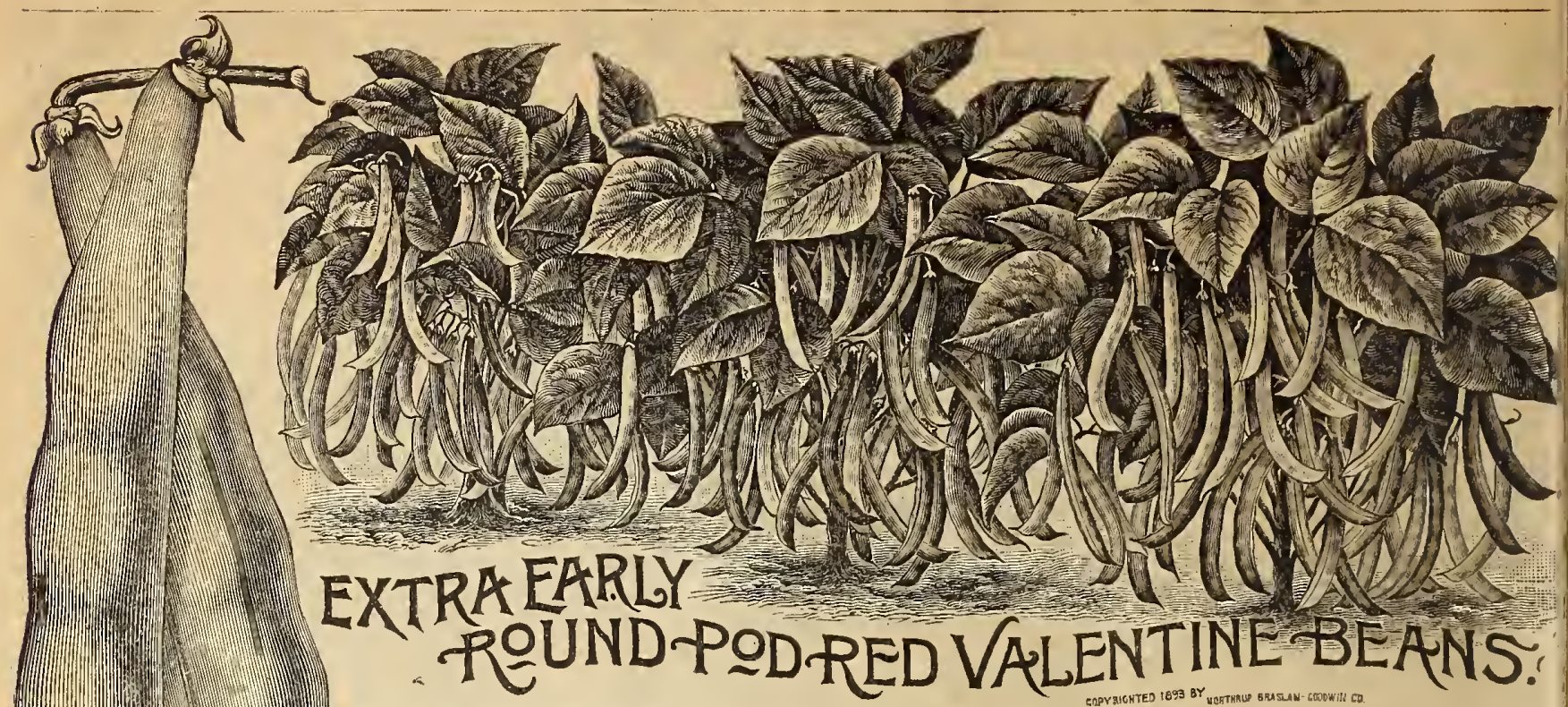

Der g yax

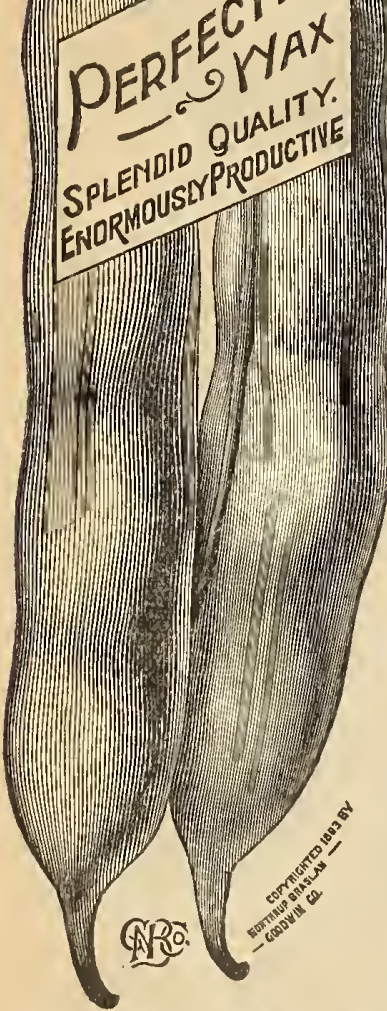

REDVALENTINE.(Extra
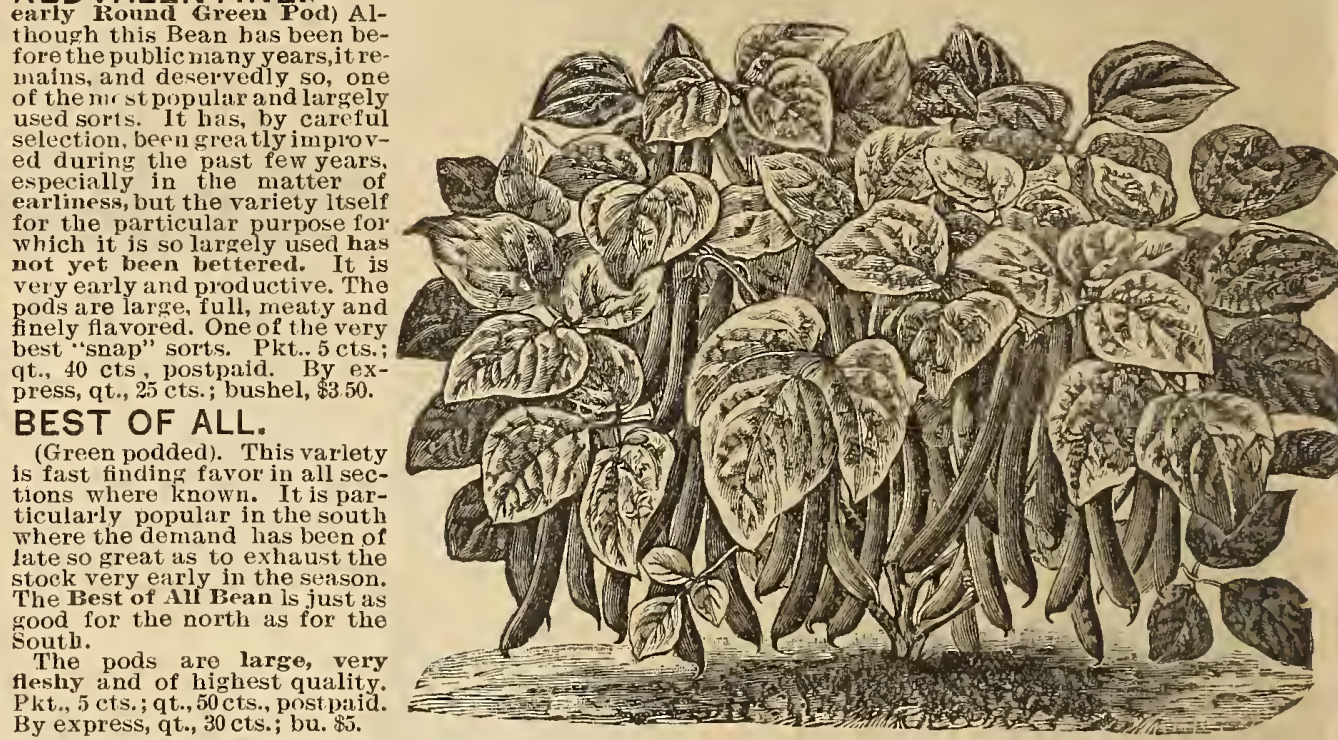

CANADIAN WONDER.

Der.

though the sales have been very satisfactorly, we feel

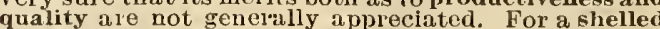

it possesses a richness and delicacy of flavor found in no

very thrifty and bears in great profusion straight pod
from eight to fifteen inches in length. The bean itsel

when ripe, ls, in color, a beautiful dark crimson. We
feel very sure that those of our custoners who are now

$\mathrm{Pk}^{+}$., 10 cis.; qt.,50 cts., postpaid. By express, qt...30

PERFECTION WAX.

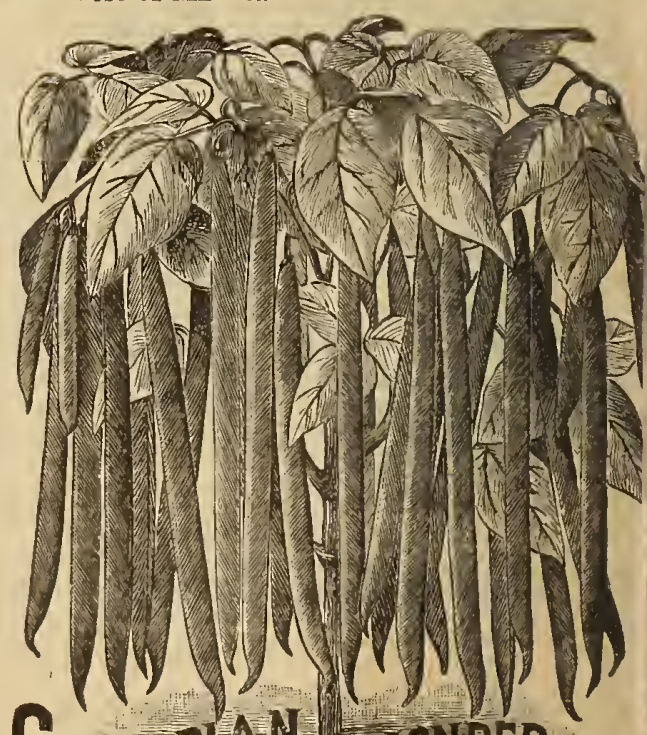

Canadian m aonoer 


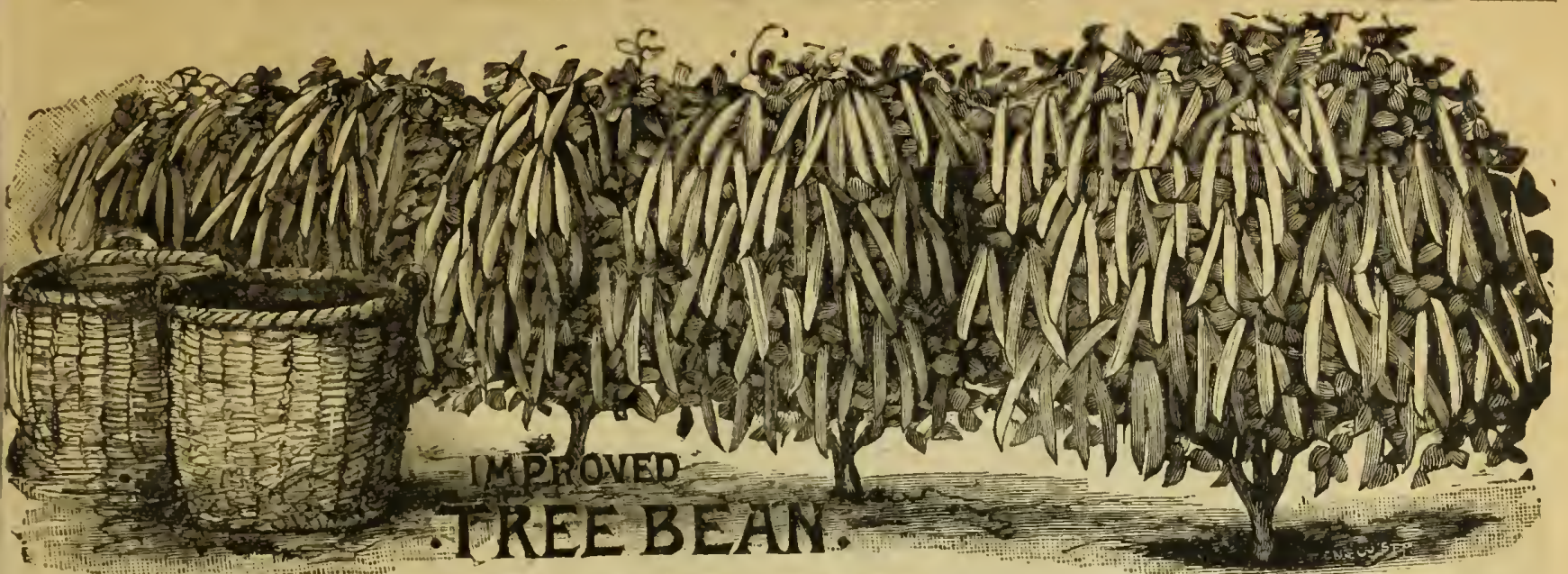

IMPROVED TREE BEAN.

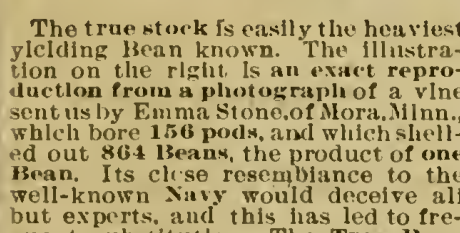

but experts. and this has led to frequent substituton. The Tree Bean mature. Ten to twelve quarts will for the cenuine Tree Bean. Pkt., 10 cts. . 9t., 50 cts., post paid. By express Bagsinelinded.

der the us a source of constant wonteliigent should plant mixed seed.

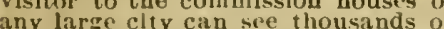
bushels of Beans, clean. bright and of cood sample, but haariy mixed as to the grower, as any varicty of Bean. price muxt be st ralght stoek. Let ils

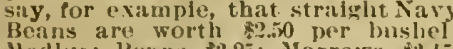
If mined with each ot her they would sell at a dischunt of rom on cts. $t$ farmers would gialn by plinting por crop: Additional price
bu-h.. 30 bucli..

Net gain

Can farmets a frord to lone $\$ 10.00$ to \$ 0.00 per acrewlich they can watin fron nvestment lyy planting

sis.

\section{\%}

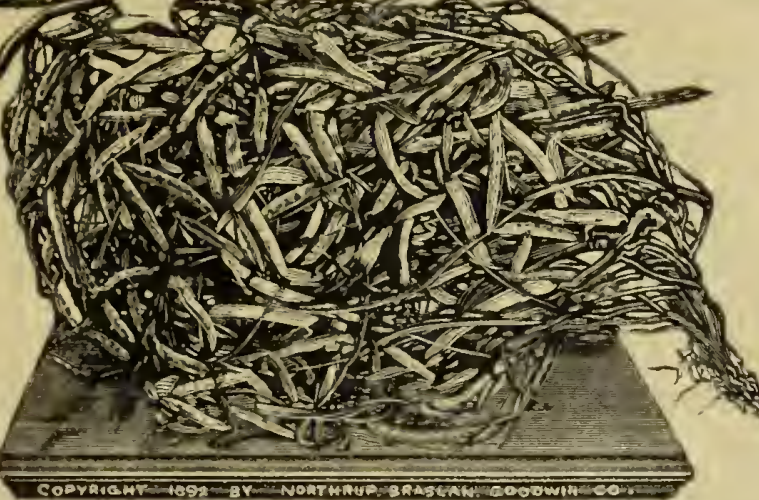

THE PHOUUCT OF OXE TKEE ISEAN

(From a Photograph of a Dricd Stalk.)

156 PODS, 864 Beans from a Single Bean.

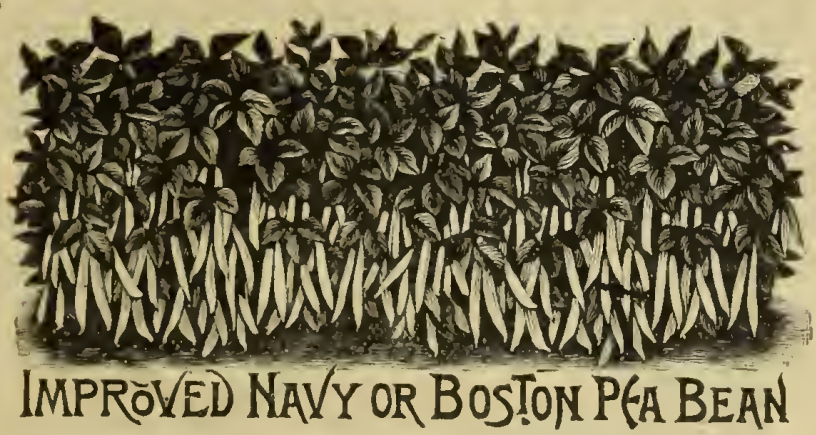

FIELD BEANS. He sure that youphat pire geed of whatever varlety of field beans you may many times over pay the fourcased prlce always paid in evcry market N., 13., G. Co.' Choice Navy paid. By express, gt.. 25 cts. ; pk., N., 13., G. Co.'s Choice Mrediam pald. By express, qt., 25 c ts.;peck, Beans. Pkt., 5 cts.; qt... $40 \mathrm{cts}$, postSWEDE BEANS. There has during the past few years, but unable to offer them. They are a ling a high price in the northng nearly always exceeded the The Beans, when dry, are brown in color, mediurn slze and a most ostpaid. By Express, qto, 30 cts.; English or Broad Windsor Bean. The are well-known in England owing to the frequent calls our cus-
tomers have made upon us for E. .J. Willince, of Willamaburg,
Iowa. Co. lowa, writes:-I purrhased seeds of you in 1891 and
they an

Price List of Standard Garden Varieties of Bush Beans, Not lllustrated.

$$
\text { PRICES INCLUDE BACS. }
$$

WHITE WAX.

CRYSTAL WAX.

IVORY POD WAX.

RUST PROOF BLACK WAX.

DETROIT WAX. Large, stralrlit, llat, whow strlurless poul

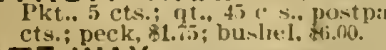

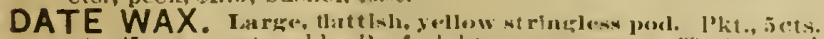
91..5 5 .5 cts., post

WHITE VALENTINE. Early snn?. roond, green pod, l'kt. EARLY, 150 : bushei, AR
EARLY YELLOW, SIX WEEKS. Narly map, large,green,

CHINA RED EYE.

EARLY REFUGEE karly NMap round,

MARBLEHEAD HORTICULTURAL. Warly map,large,

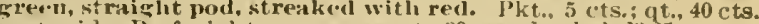
HORTICULTURAL.

BOSTON FAVORITE. Early map, large, greent, wt traight pord. or cxpressi, at., 3i cts.; peck. 11.00 ; butshel, 23.50 .

LOW'S CHAMPION. Warly snap. large, green, st ralght pod. 


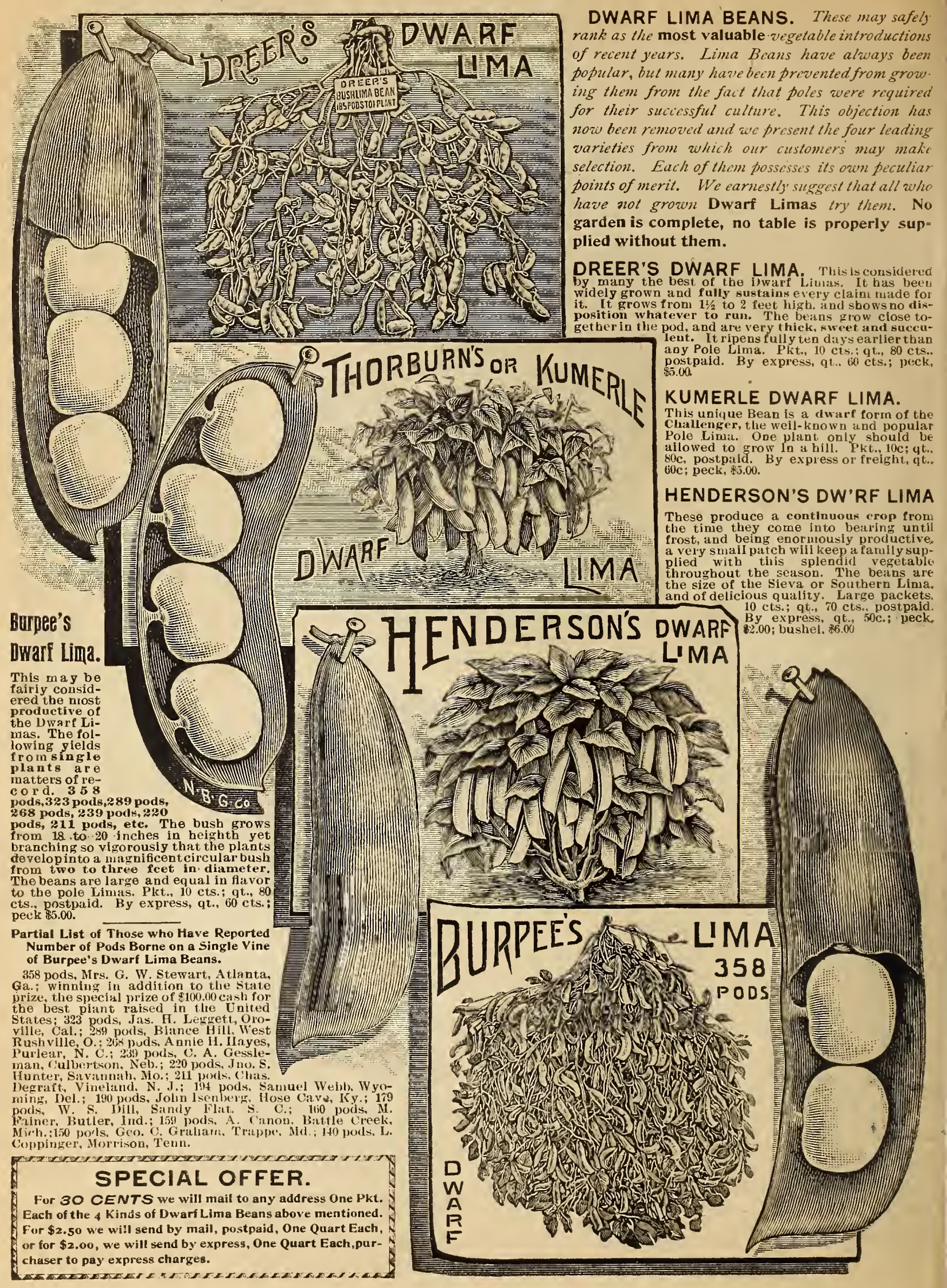


BEANS.-POIE VARIETIES.

\section{SEWLIETRUNNERBEANS, S) 2 BEAUTIFUL IN FOLIAGE} A 20 JANDBLSSOM" 1 - ESURPASSINGINGUALITY T. 27. 1 .

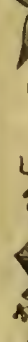
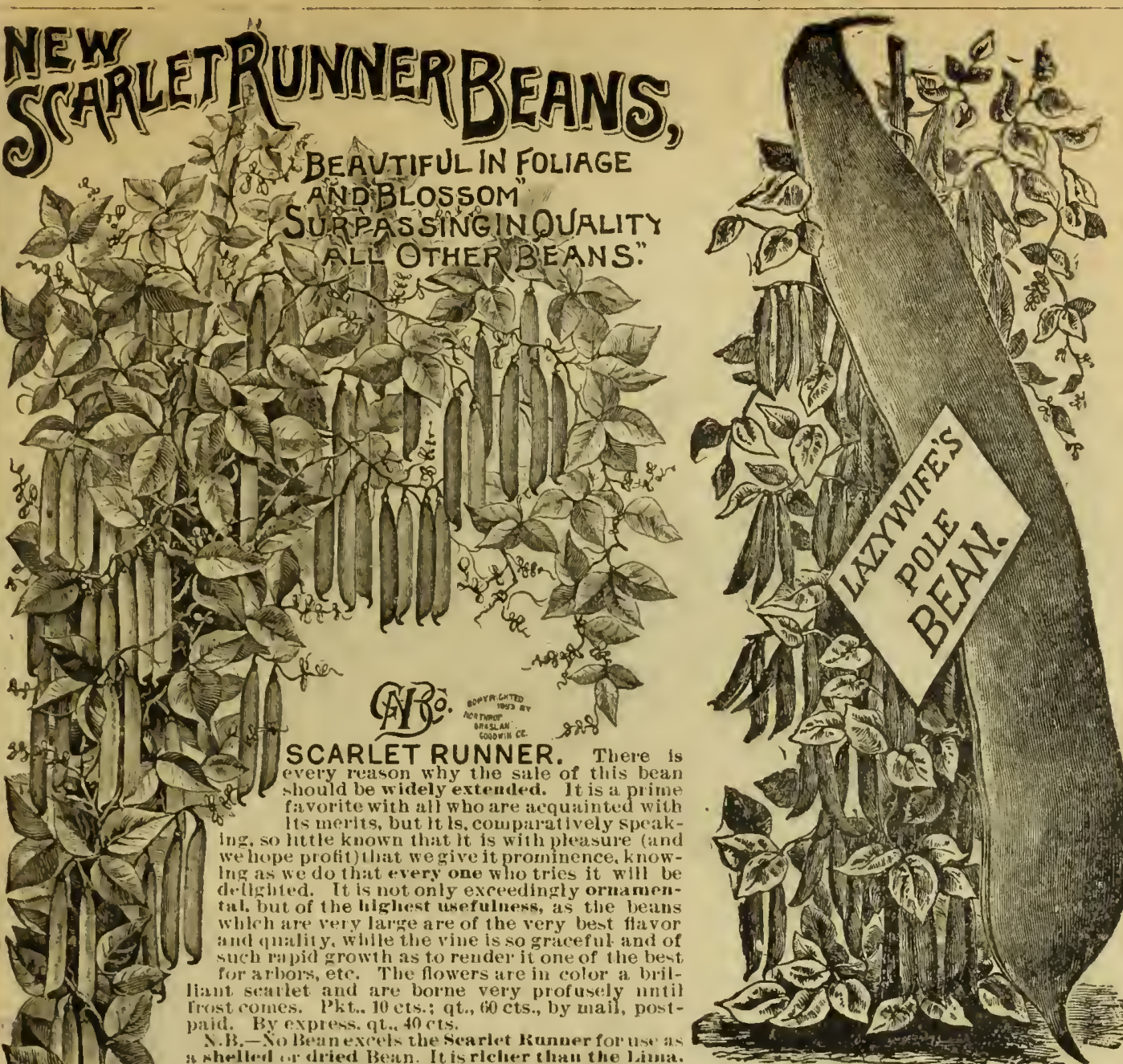
BeEt, garden SORTS.-For Mangel Wurzel and Sugar Beets, see. Farm Seeos, Page 46.
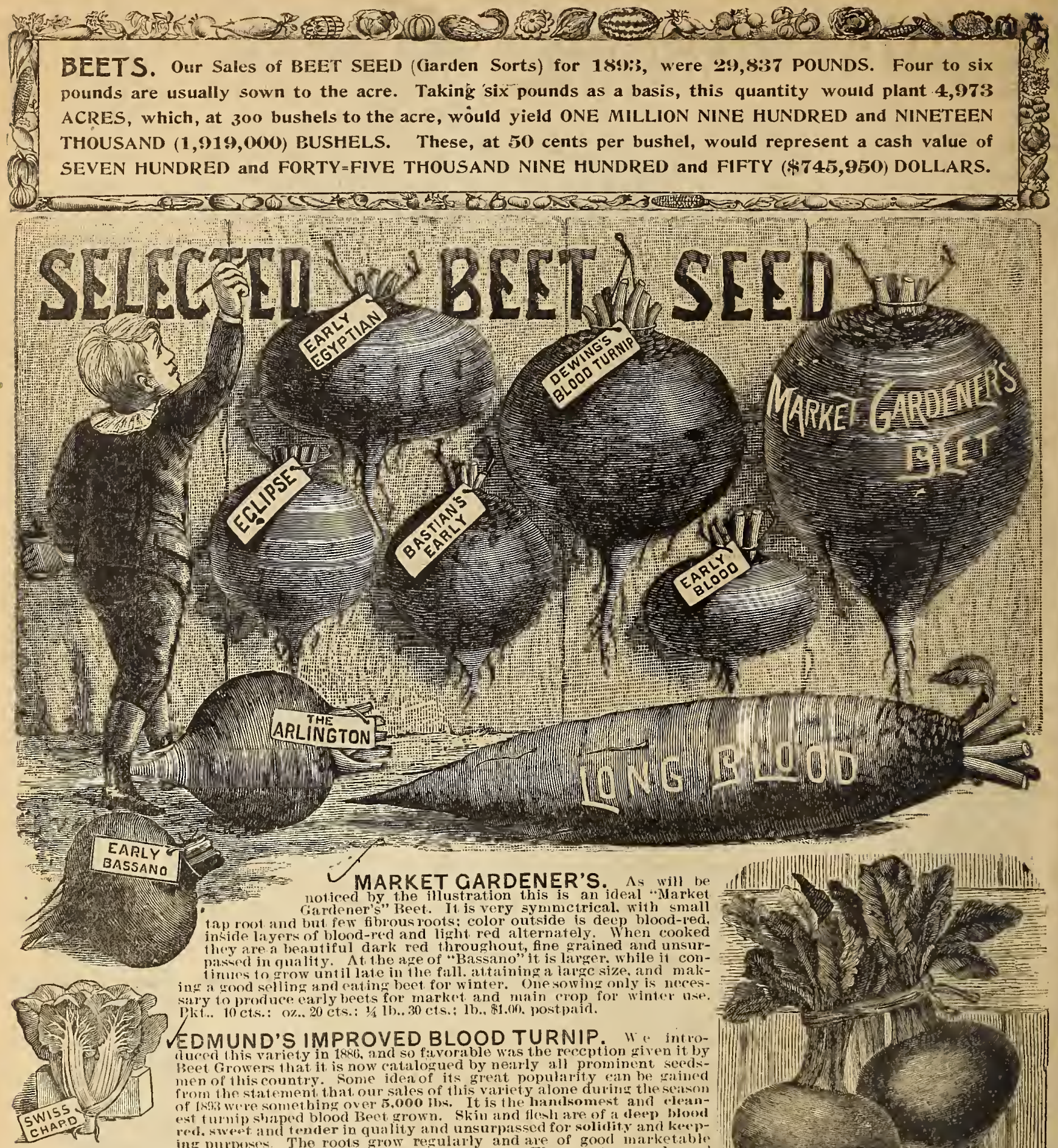

gCLIPSE Flly as early its the Bastian's and of better quality; loots round and smooth,

BASTIAN'S BLOOD TURNIP. Ilighly esteemed by market gardeners. Plit.. 5 cts.

DEWING'S BLOOD TURNIP. One of th

EARLY BLOOD TURNIP, Roots turnip-

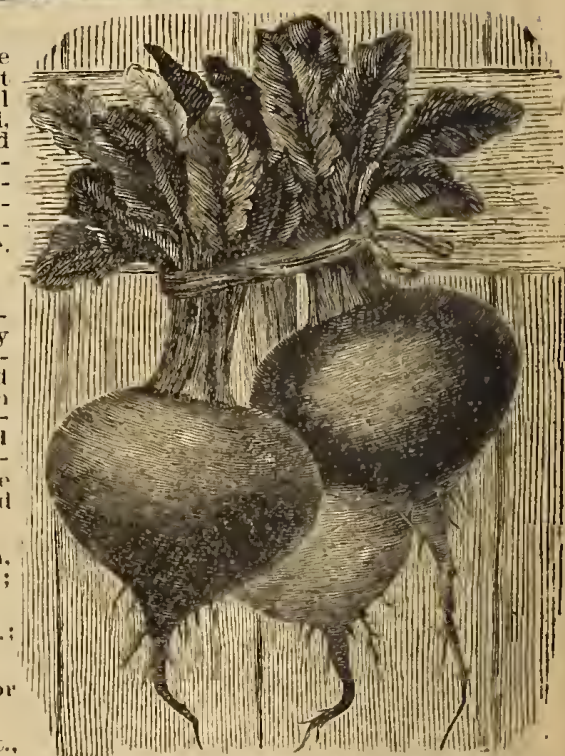
EARLY EGYPTIAN. The earliest sort., and

Edmund's Blood Turnip Beet.

EARLY BASSANO. One of the earliest viris

THE ARLINGTON. This is a very popular variety in the Eatstern markets, being some what larker than the luewing, and of very fine LONG SMOOTH BLOOD-RED. One of lire hest and most popular table beets especlally for autumn and winter use cour seed SWISS CHARD, OR SILVER BEET, Much superior 10 the common beet for greens, and if wown at the sime time will be fit. for 

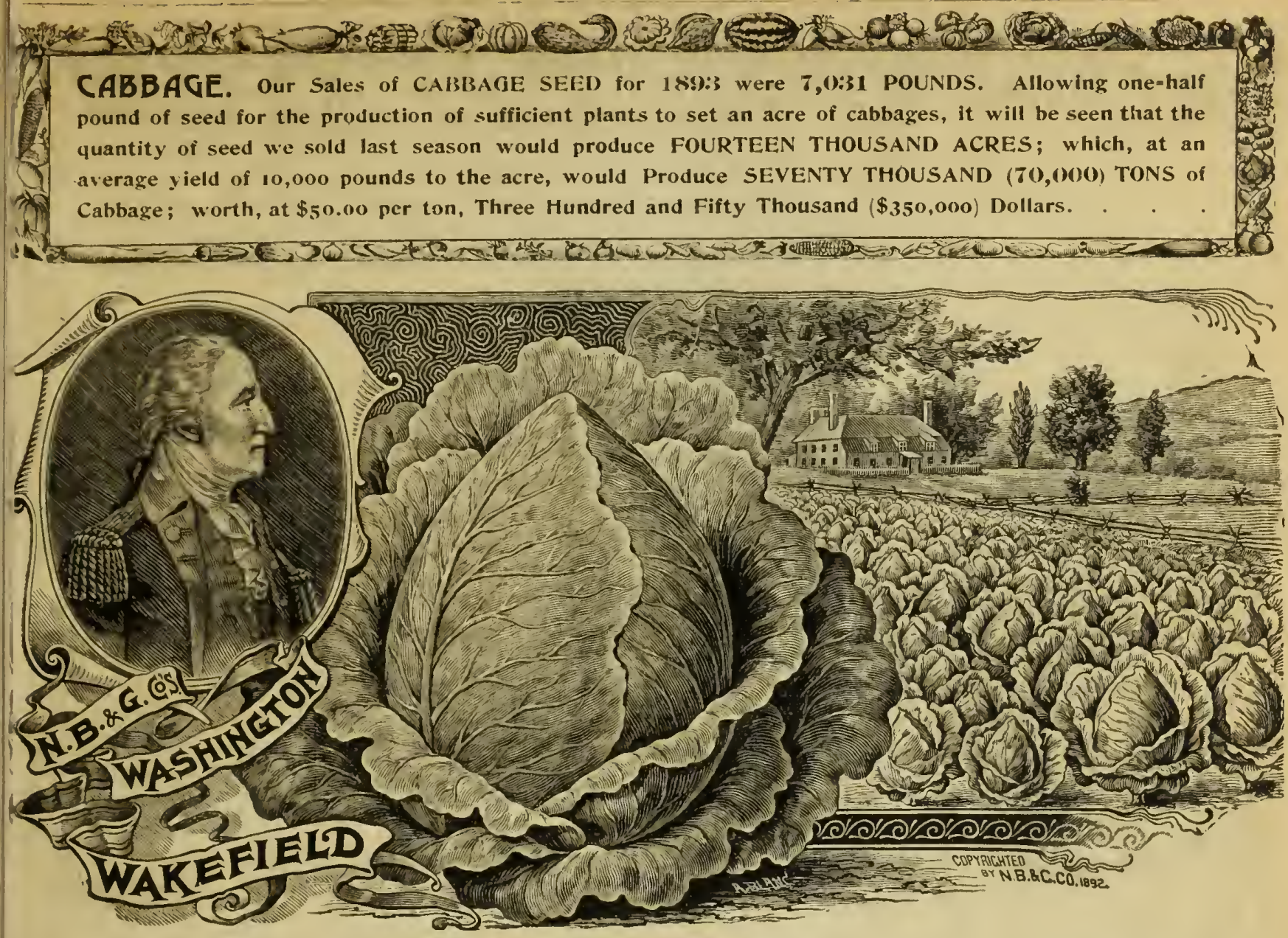

WASHINGTON WAKEFIELD CABBAGE. (Early.) We introduced thingrald Cabage in 1893, at which time our stork was very limited. We lave received so many letters of praise and congratulation regarding it, that it seerns as though every one who tried it must have written to make known their sitisfaction. Such expressions afford us great ploisire, ind it is with renewed confidence that we again offer this splendid Cabbage -

“First in Mead! First in Market! First in the Hearts of Gardeners!"

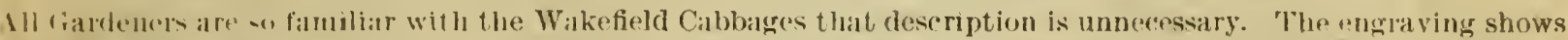

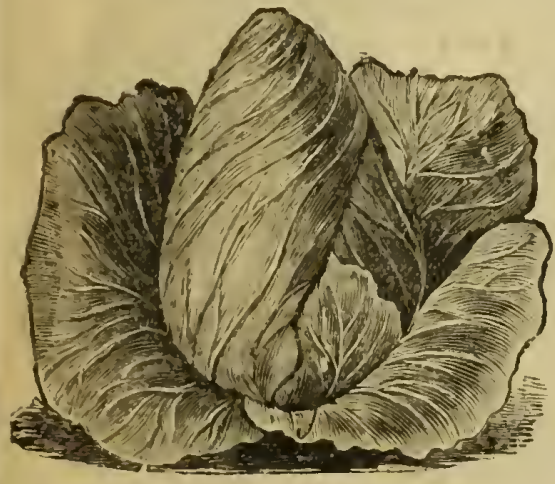

Larly Jorsey Waketielol.

\section{EARLY JERSEY WAKEFIELD.}

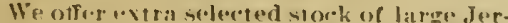

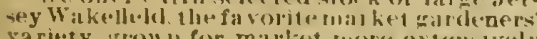

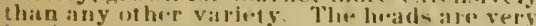
hard. compalet. solid. and of coniral shape. as shown in the illmatration frw ontside

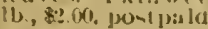

Cer Wo do met molonit that this whek haw any superior eregt the Wistivitis WI KH:FIEI,IS.

the character of the Washiugton Wakeficld, and it is perhaps sufficient

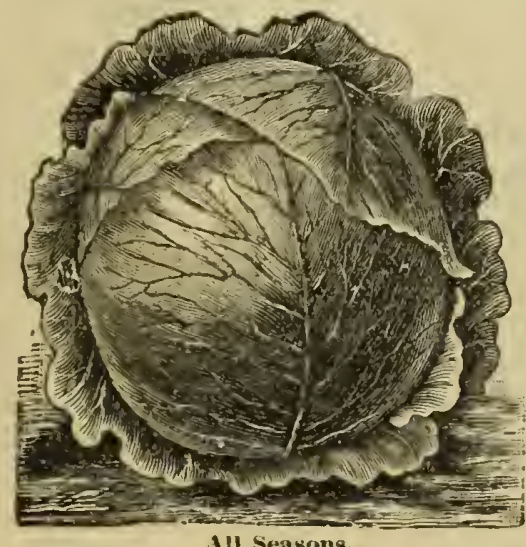

ALL SEASONS.

The hearls are very harel and solld, round, Mattened on the toj), of thi. virey best quat-

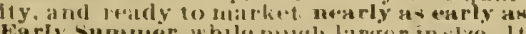

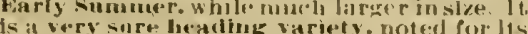

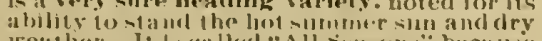

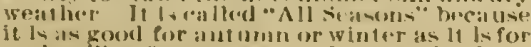

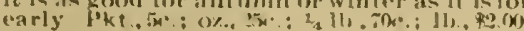

earliness, size of houd and purity of stock. Pkt., 1ic cts.; o\%, 50 cts.; t $11, . \$ 1.00 ; 16 ., \$ 3.00$, posi paid.

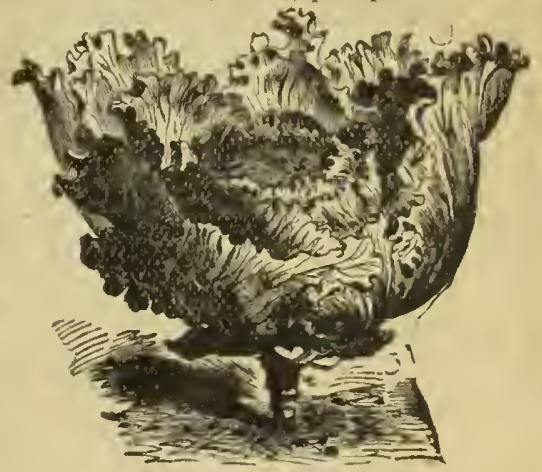

Munmotil Rock Find.

MAMMOTH ROCK RED. Very unch lioger hoirls tlatu the old Red Dutall Nine'y-five per ("cul, of the plants solid piokling or 1 inble use there ls no better varicty of red culshase l'kt.. 10 ets: 07.., 30 
CABBAGE.-Two Good New Ones.

\section{TWO SPLENDIDNEWCABBAGES}

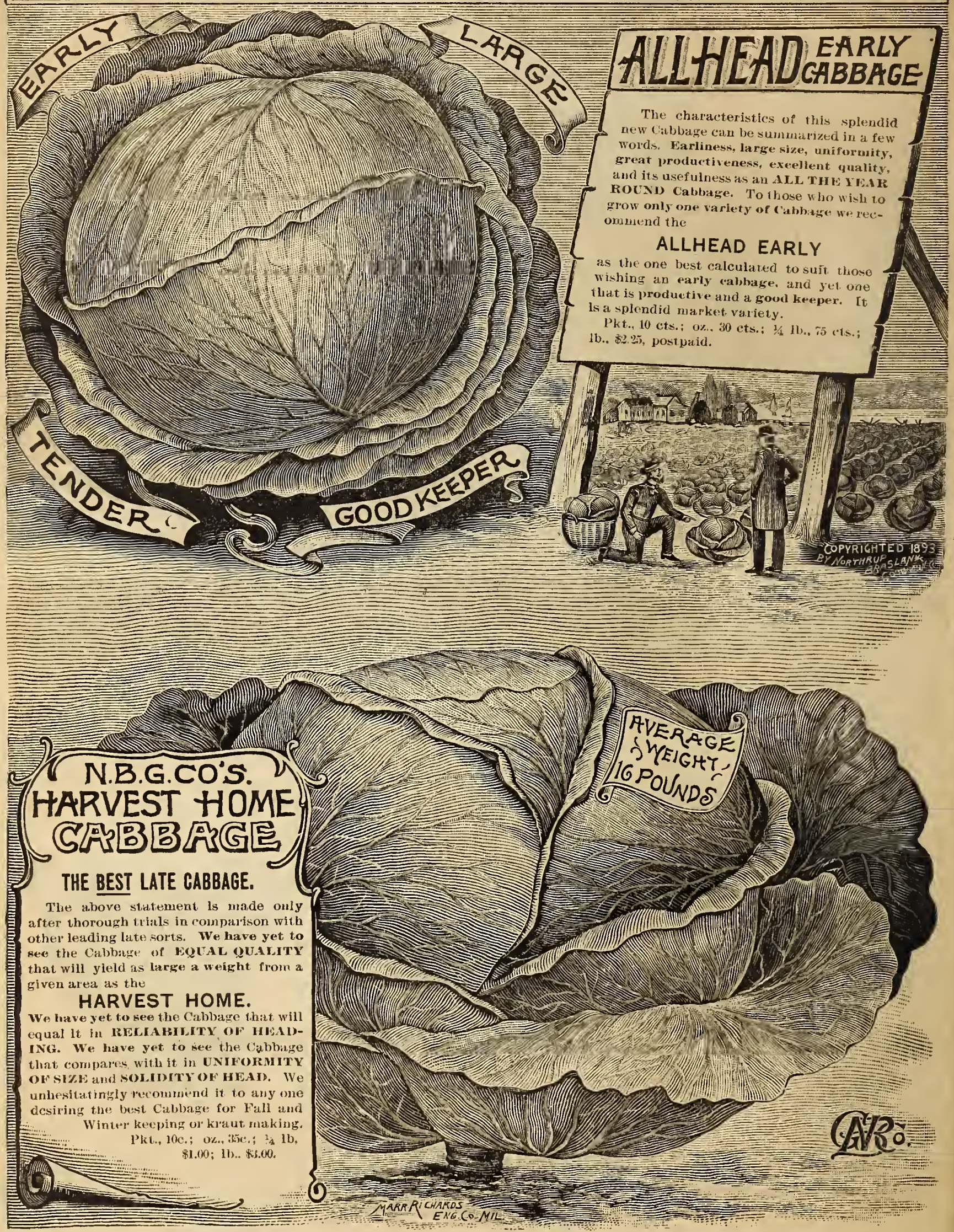


CABBAGE.-STANDARD SORTS.

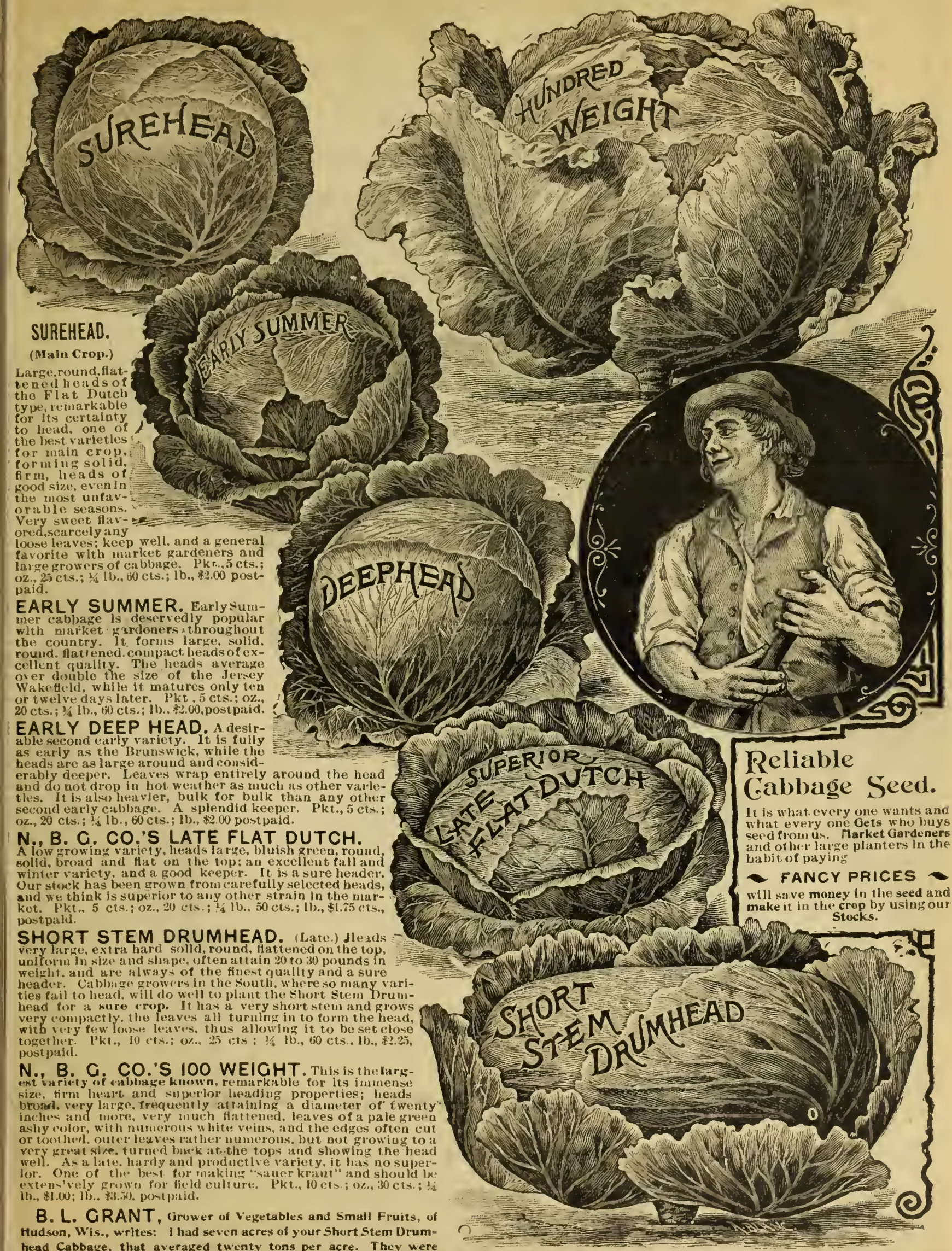

pronounced by all who saw thein the finest lot of Cabbages they liad ever sceen. Numerous single heads, trimmed close, weighed as high as twenty four Ibs.., and averaged ten Ibs. each, field run. I strongly recommend it to any one desiring the best Cabbage for Fall and Winter keeplng. 


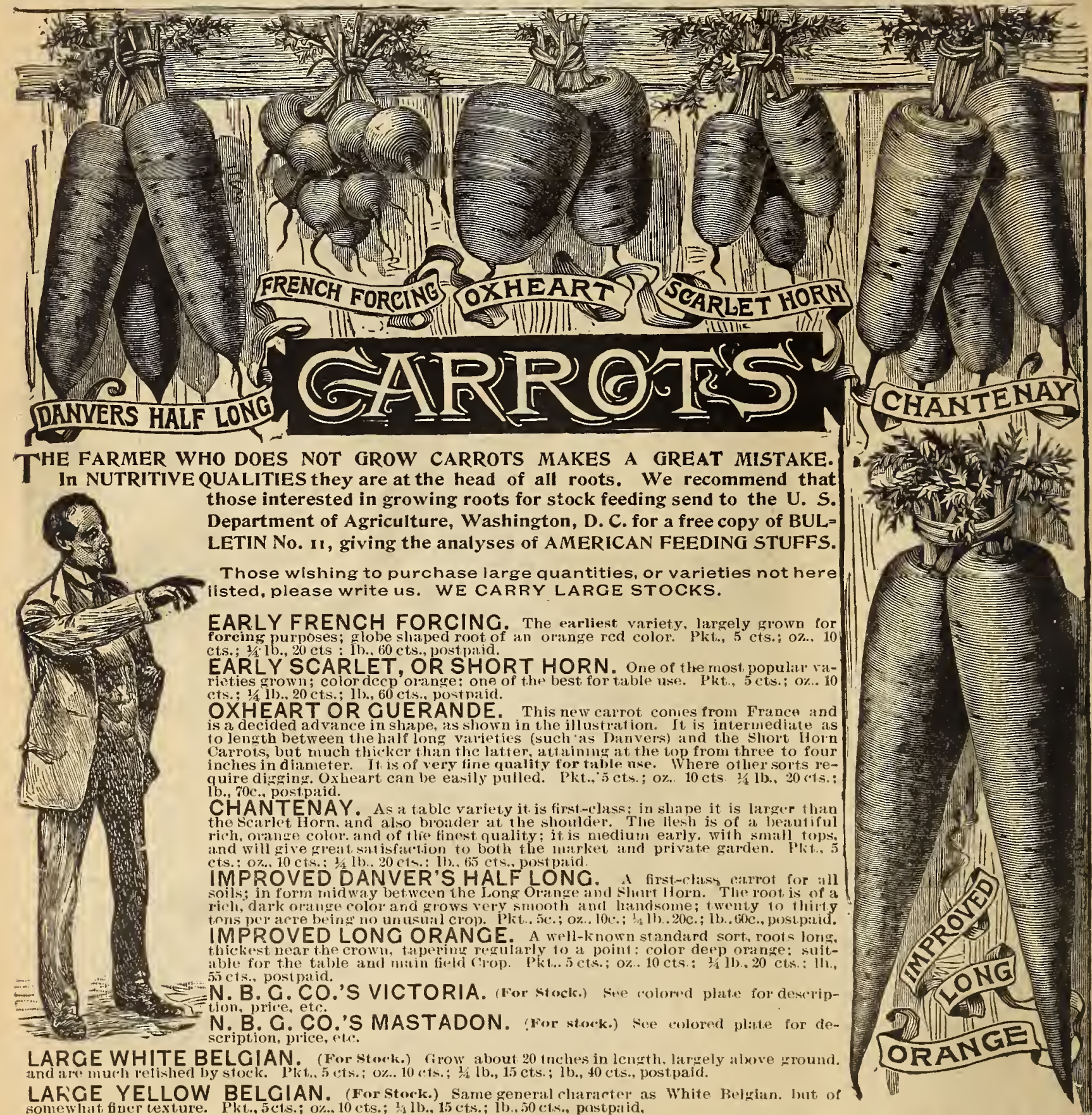

John Fkiof, Cokato, Minn, writes:- "Receive my thanks for the seed vou sent me, It arrived in due tinie, the weight or measure being very libera! and the prices low compared with what I get from others."

J. B. Harter, Morrill, Kansas, writes:-"We can't think. of doing without your seeds. We have got seed of you now for three years and we have good success with them.

J. C. Carlton, East Concord, N. H. writes:- "I was well pleased with the seeds I got from you last spring, and shall give you a good order for next spring as soon as I hear from you. 


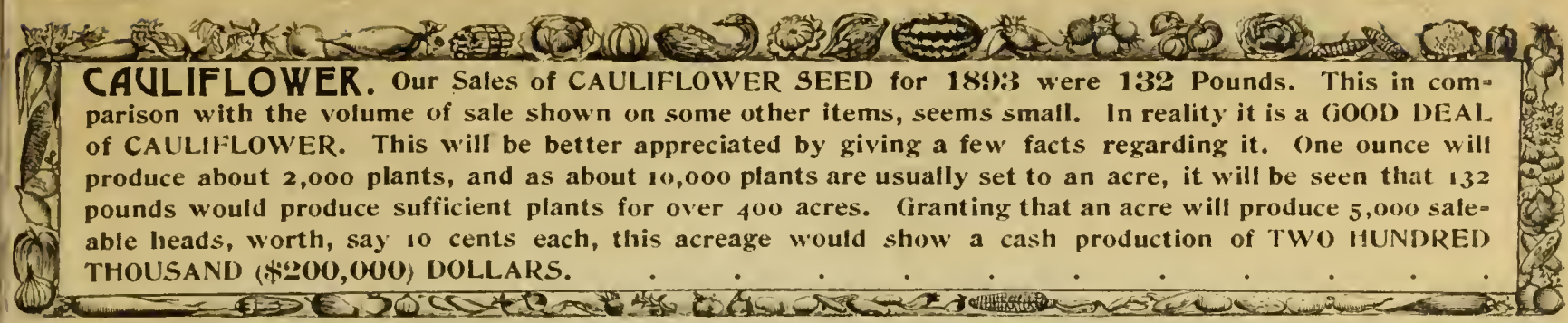

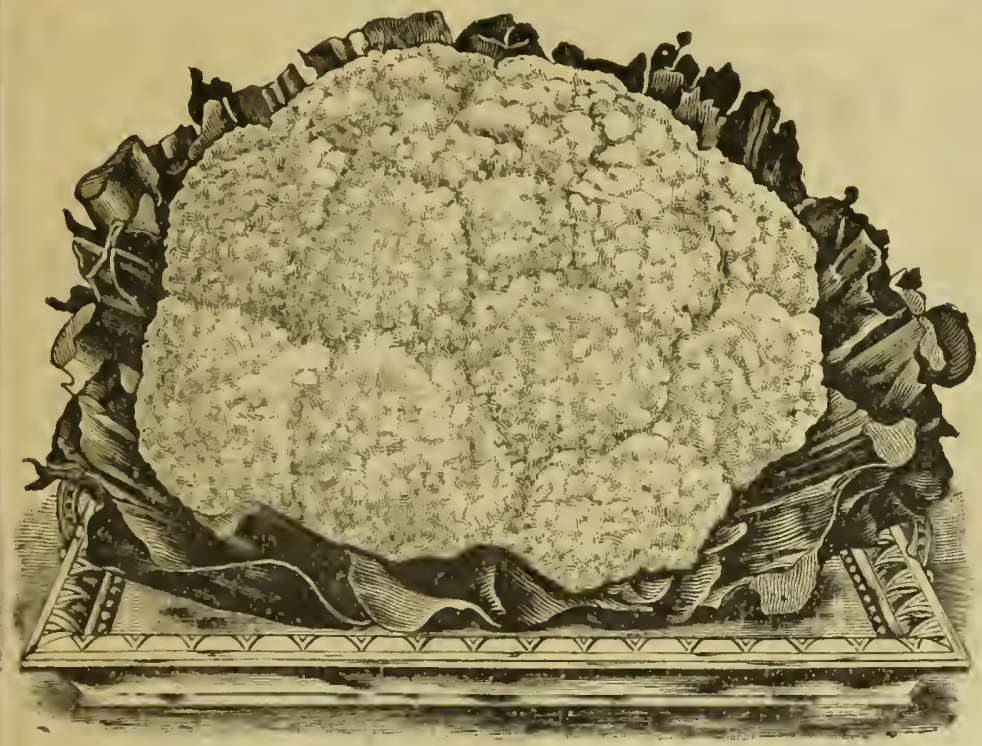

C., I3. C. Co.'s Model Caulillowe.

CAULIFLOWER. The increase in popularity the cheerfulness with which all growers pay, sonetimes, an UNREASONABLE PRICE for the seed, hes led us to devote a good deal of attention to this importunt article. We invite tho attention of those who want the EARLIEST and FINEST Cauliflower to the NEW MODEL, and to the very reasonable prices we place on all varieties.

N. B. G. CO.'S MODEL.

(a) acconumying it elaimen it to be ary We planted this iu our trial grounds, and after comparing it carefully with all other tarly varietires, we concluded
that it wis fairly entitled to be called ille brot sauliflower me the groming. sacessive trials have proven it to be as early as any "anlithower not the very carliest, while in equal. We at once arranged with the party in Denniark. who originaly sent us the seed, for a llberial quantity, aud plowe for early plinting, best also for late plinting on account of its close growing habit, which allows many more plants to HENDERSON'S SNOWBALL. Too well knowu

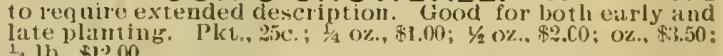
EXTRA EARLY PARIS Good for forcing; ib., $\$ 7.50$.

HALF EARLY PARIS.

LARGE EARLY ERFURT TH a laree ind vigrorons growing vuriely, with Plit. 10 cts.; 0z., \$1..5.

AUTUMN GIANT. (Late.) hieads large

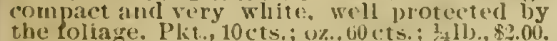
ALGIERS. One of the largest and best forlate use; forms litge, solid and very white

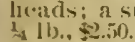

Lenormand's Short Stem Mammoth. (Late.) Producing large fince Ireads of good substance. WALCHEREN.

CELERIAC. Turnip Rooted Celery. Grown exclusively for its roots; excellent for salads, for seasoning meats and flavoring soups. LARGE ERFURT, Root-1arge. smooth

GIANT SMOOTH PRAGUE. Short

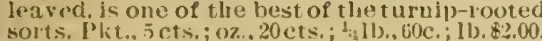
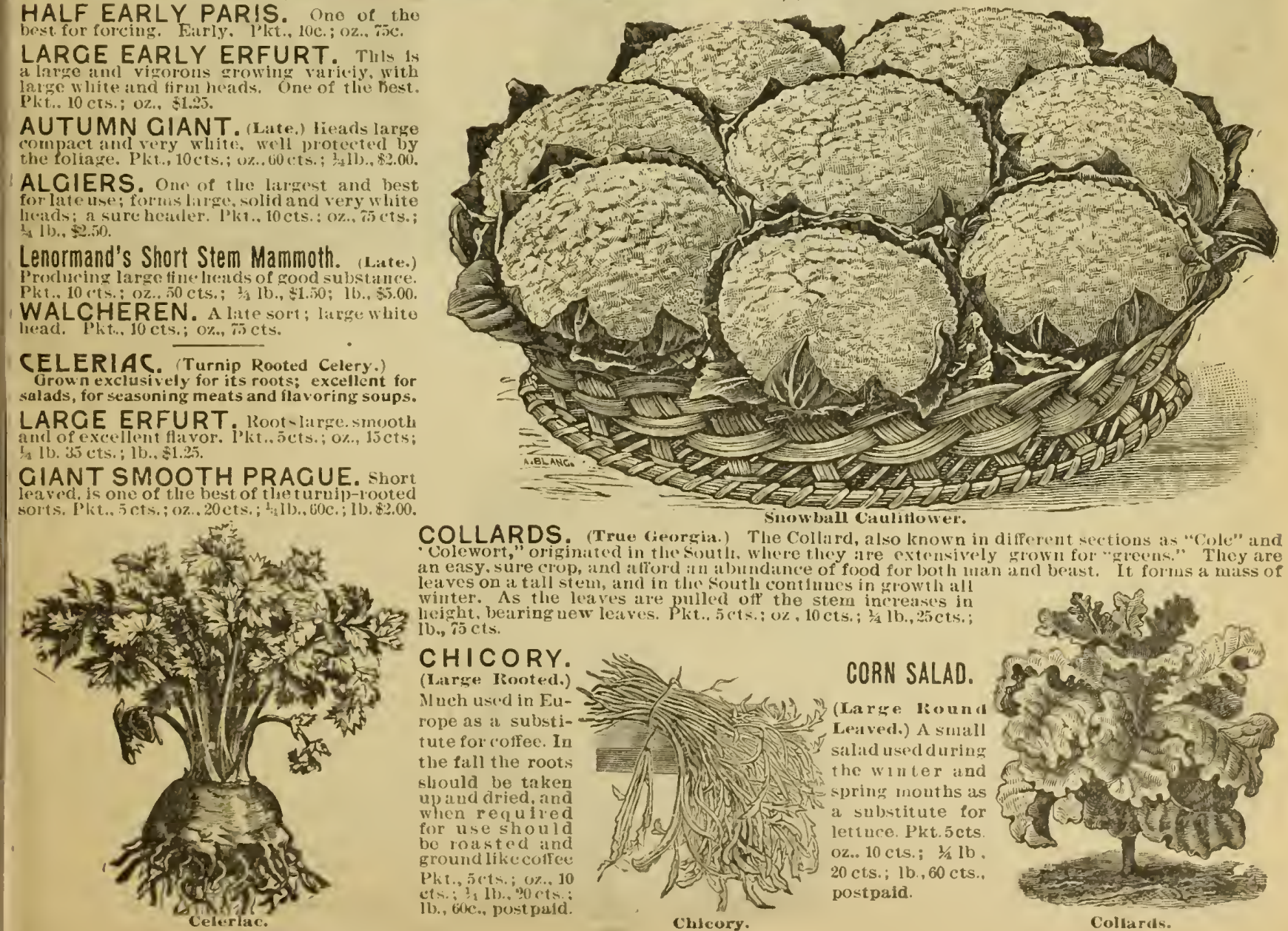

COLLARDS.

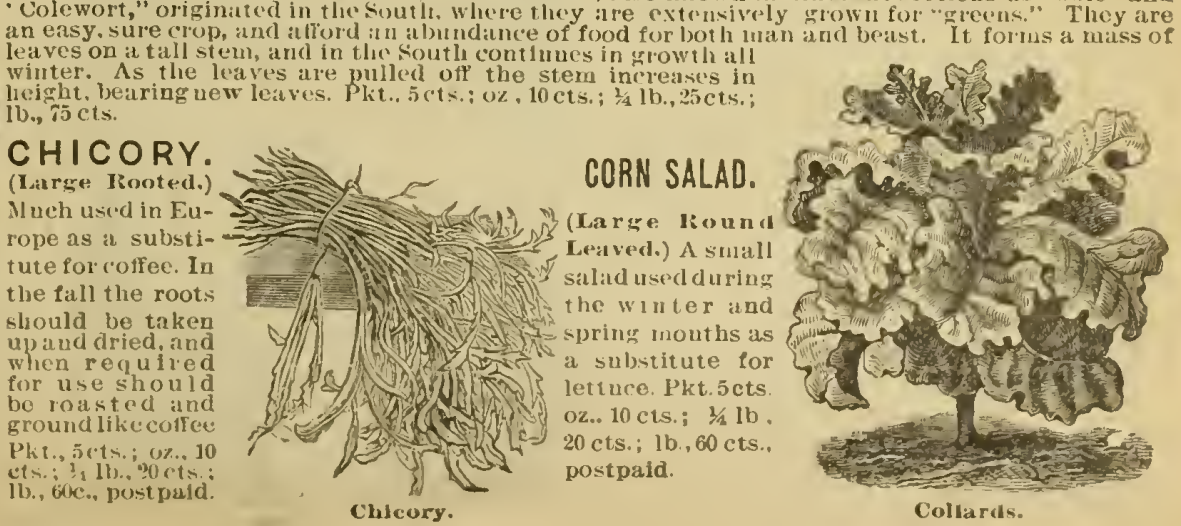




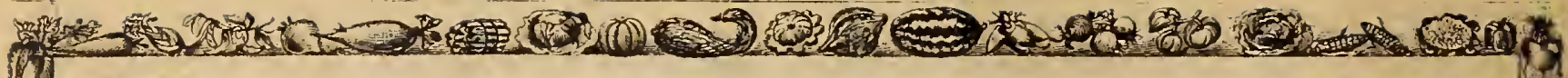

CELERY. Our Sales of CELERY SEED for 189 ):3 were 1,6n9 POUNDS. It requires about one-half pound of Celery Seed to produce plants for one acre of ground. 1,(559) Pounds would, therefore, seed

s. about 3,300 ACRES. Five Hundred Dollars is not a large sum to receive for an acre of Celery; at this

1. value the crop from the acreage, above given, would be worth over ONE and ONE=HALF MILLION

(1) $(\$ 1, \overline{500}, 00)$ DOLLARS.

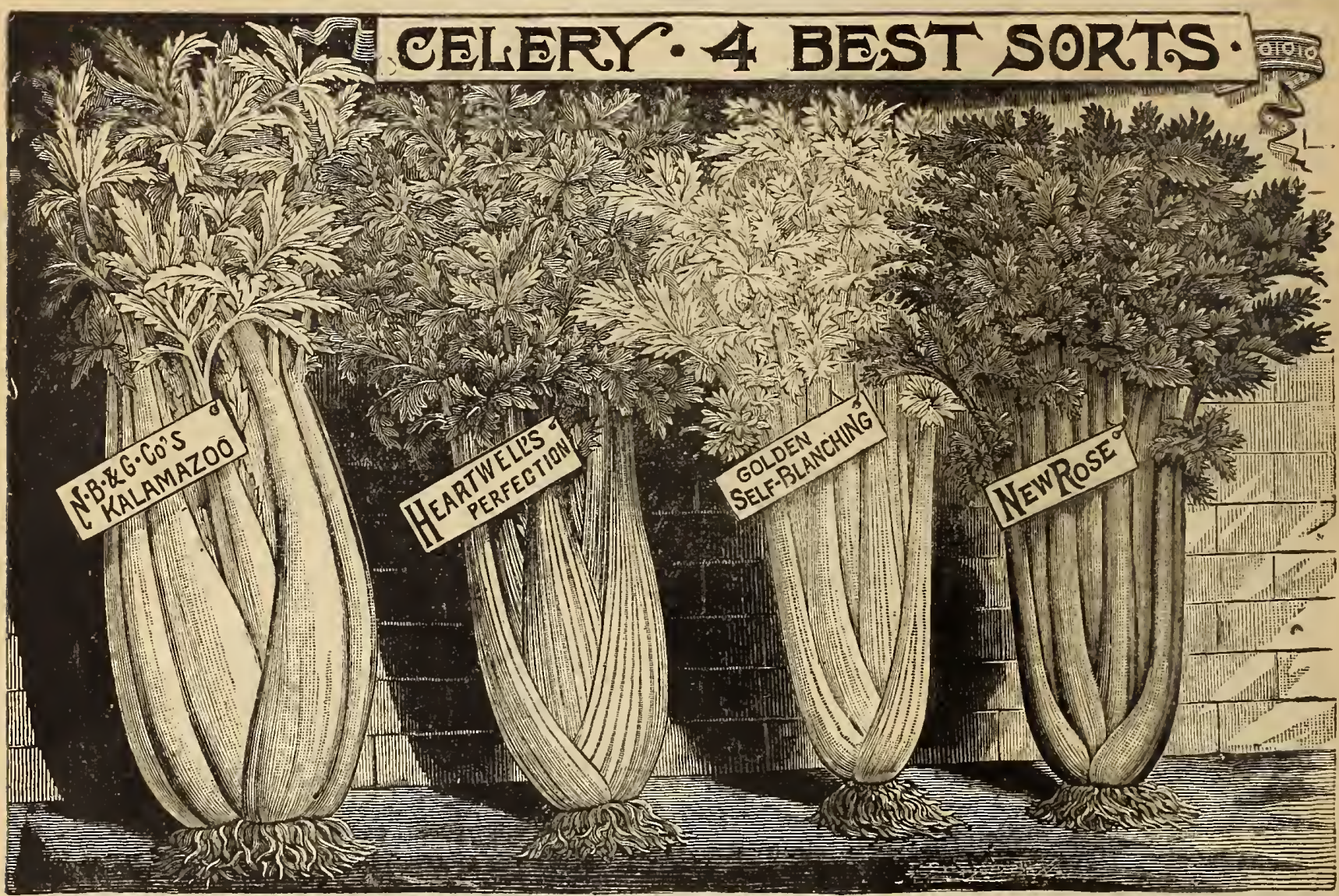

N. B. G. CO.'S KALAMAZOO CELERY. (True.) The most solid, crisp-eating and delicious flarored variety, one remarkable

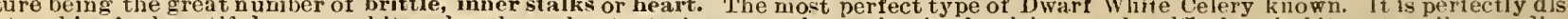
tinct and is of a beautiful cream white color tliroughout, attains a very large size, is of qulck growth, stliti, close habit (outer ribs standing arre establishments, it is unequaled, there be

\section{CAUTION}

their supplies fron
(x. Co.'s kialamazoo.

HEARTWELL'S PERFECTION. On

rreat keeping qualities. Very solid and neve

GOLDEN SELF-BLANCHING.

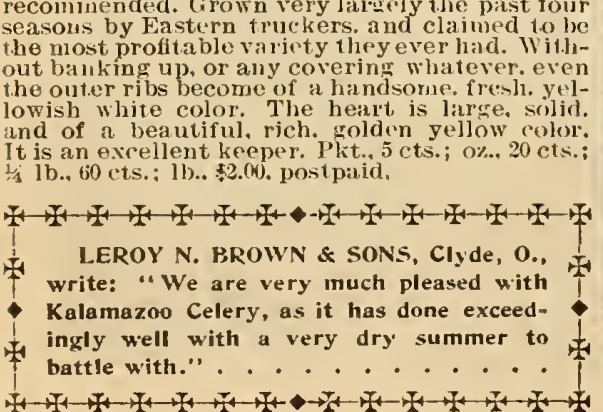

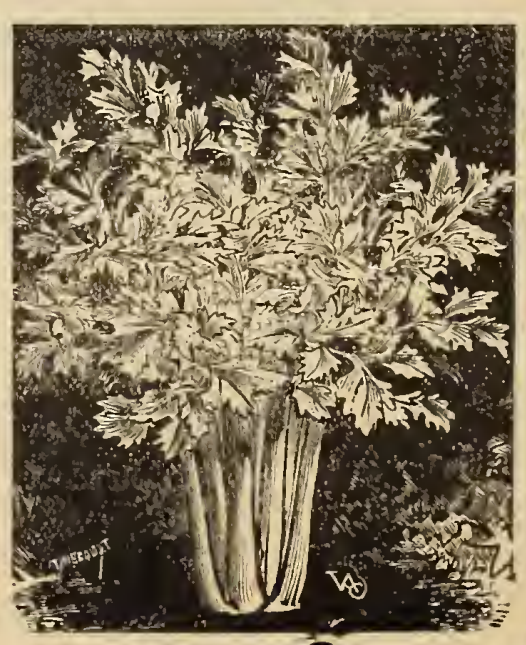

White Plungerelery.

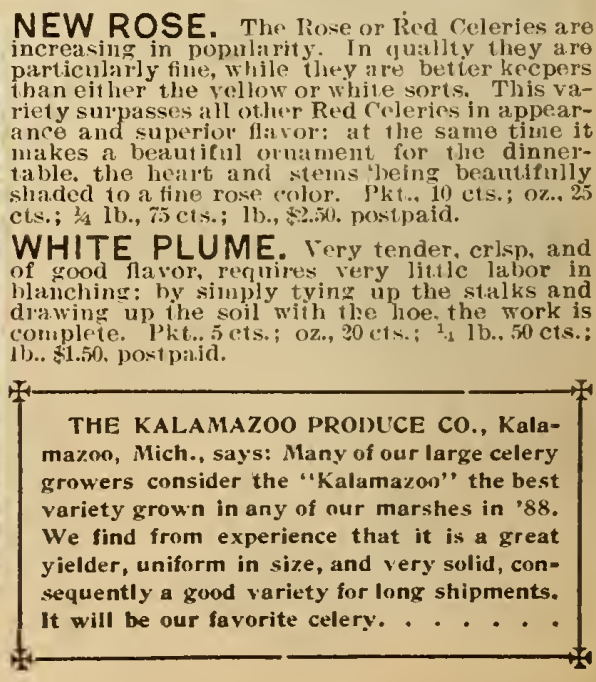




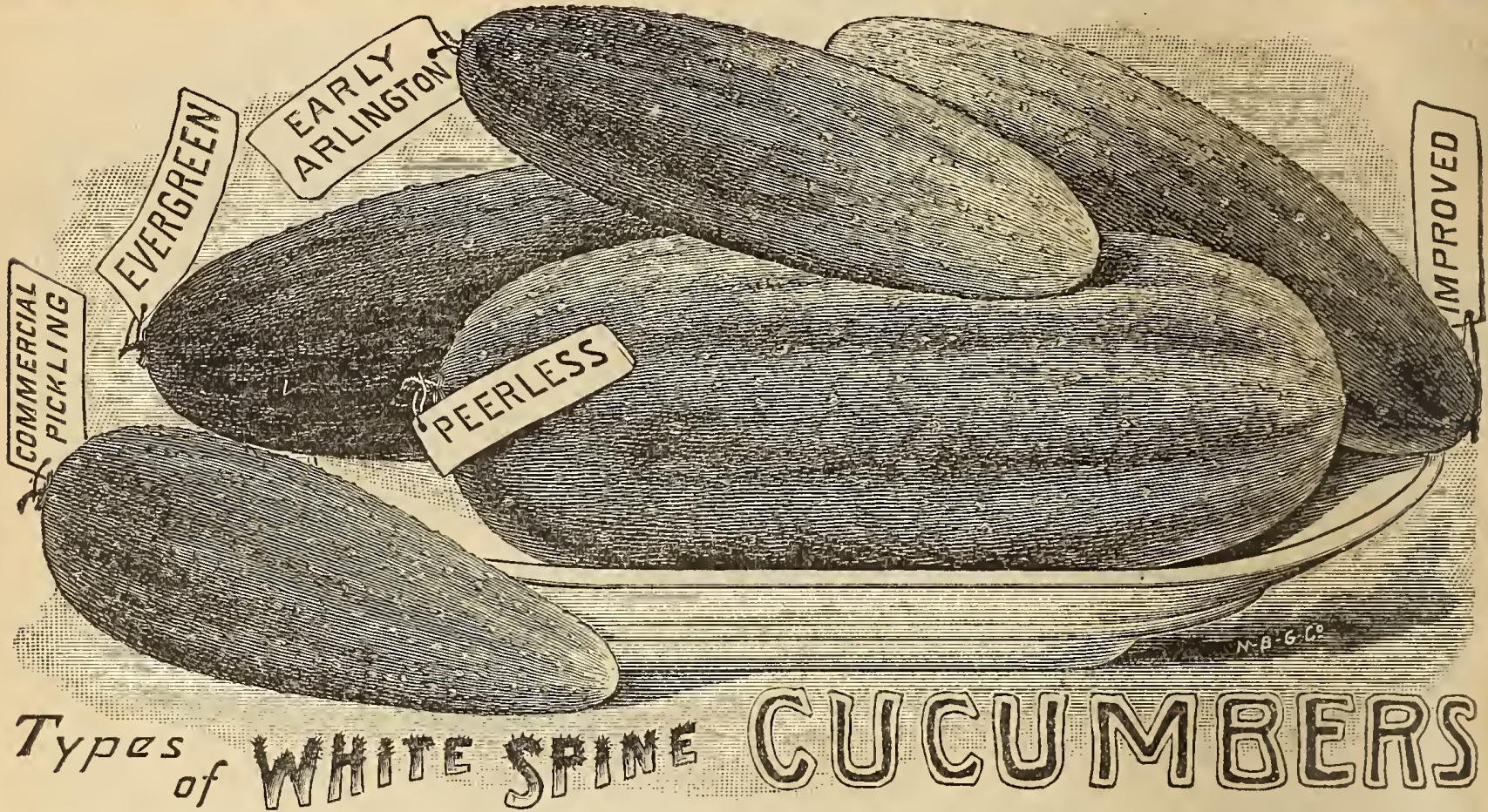

EARLY ARLINGTON WHITE SPINE. Color, deep green, shiadno 10 white at tip or blossom end. Shilpe aniform, somewhat tapering at both ends. This is the smankst of the White spine

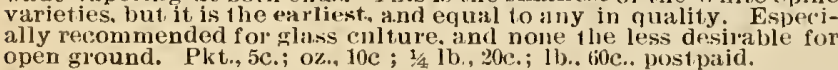

IMPROVED WHITE SPINE. The description for this variety is similar to the above. as it, is the parent stock front which the Arlingtoll was selected; about the only diference crasisting in what larger. Quality excellent. The old standard variety. None
better, or more generally and favorably known. Pkt., 5 cts.; oz., 10
cts.; 1/4 lb., 20 cts.; 1 b., 60 cts.. postpaid PEERLESS WHITE SPINE. Following the Improved white spine in point of eirliness. but atitaining a larger size. Very at either stem or blossone ends. Color, a beantifnl green. and in all

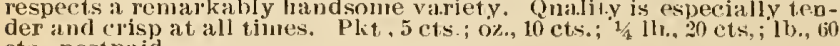
EVERGREEN WHITE SPINE. ety, and which is exceedingly at inactive wherever in any oit "catche the eye." Quality especially brittle and crisp, and devold of that peculiar bitter flavor often noticed in Cucumbers. In form it, is vely while in length it compares filvorably with the Peerless White Spine, tapering, instead of being blunt, or full. One of the best varieties for Snuthern Gardeners' trade. Owing to its deep dark green eolor it
stands long distance shipuents very satisfactorily and invariably reacles the Northern market in an apparently much presher conditconsiderable inportance to both the seller and the producer. Pkt.

blossom end. This churacteristic is particularly marked when the fruit is small and of pickling sire, and it is entirely made up of spines from one and to the other, a feature that pleases he pickle niker
pully as nutuch as the color, shape and size of the Cucumber. Pkt..

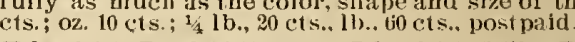

EARLY FRAME OR EARLY SHORT GREEN.

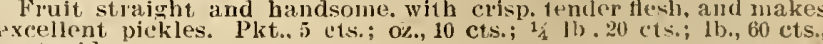
EARLY GREEN PROLIFIC OR BOSTON PICKLING Fruil short. nearly eylindrical, but poirted at each elid, ad distinet bin cts popular

N. B. G. CO.'S PICKLING. Very early and productlve, thesh crisp and tender, fruit of dark green color, whlch they re-

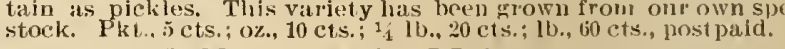

NICHOL'S MEDIUM GREEN. Very productive, of mediumsize, and alwiys struicht and sulothi color clink oreen flesh tender and crisp: inlogether a splendid cucumber. unsurpassed as a oz., 10 cts.; '1 1b., $20 \mathrm{cts}$; ; lb., 60 cts., post paid.

IMPROVED LONG GREEN. The vines of thls well known and favolite solt. form fruit for the table nearly as "arly as the

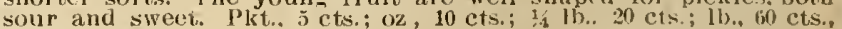
poustpaid.

WEST INDIA GHERKIN. (Tine.) Used exclusively for

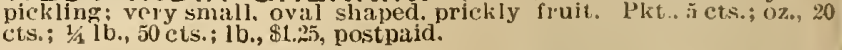
N. B. G. CO.'S SIBERIAN. Intwoluced by us ñears ago Commercial Pickling White Spine.

Color very dark green, but without the deep blue fint or bloom so noticeable in the Evergreen White the color of the Commercial Pickling is considered by far the best never was created in moro beantiful strain of Pickling Cncumbe than the Commercial Pickling. or blunt at the stem end. gradually tapering to a point at the

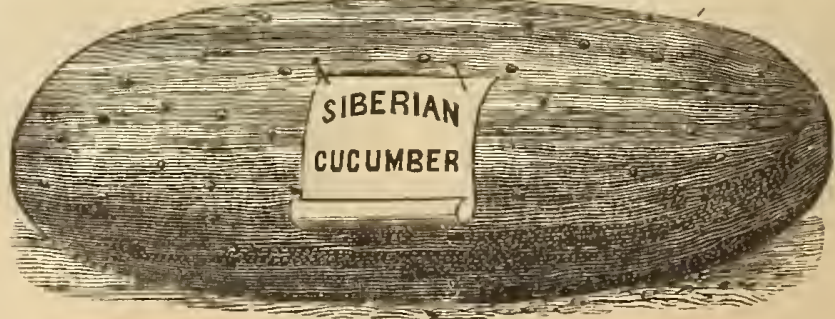

in this partleular. It produces fruits five inches long, in the oyen ground, from swed in 25 days It is
without guest ion a l'enarkable varicty, and will be a surprlse for market gardener's and truckers, Filo beretofore havo grown the the "New Siberian" medium, what it critical gasdener would call jnst right. $\AA$ splendid free bearer, fruits straight aud smooth, flesh tender and crisp. Pkt., 5 cts.; oz. I0 cts.; $3 / 4$ lb., 20 cts.; $1 \mathrm{~b} .60$ cts. 


\section{WHAT GARROTS AREWORTH}

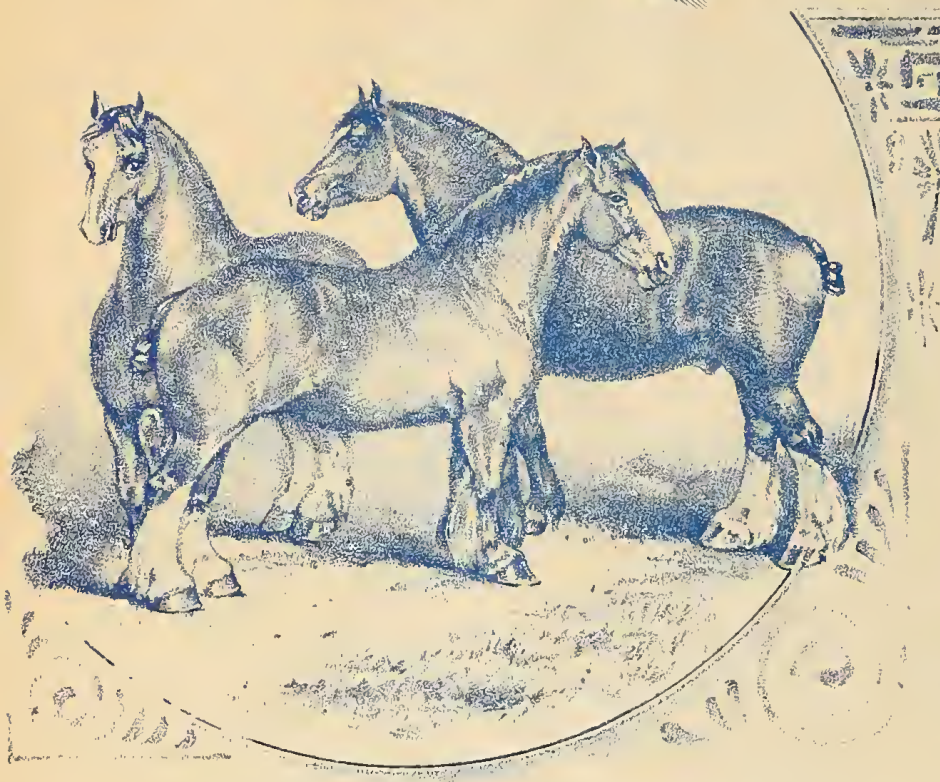

The above group (taken from lifa) show's Vill he MacGregor and her two colts, The Governor and hiss Stanley, as exhibited at the World's Fair by their cwner, N. P. Clarke, of St. Cloud, Minn.

hillie MacGremor took sweepstakes as best Clydesdale mare in America, also First Prize as mare with two colts. Miss Stanley took First Prize in her class. The Grovermor Second Prize in his class.

SPECIAL OFFER, In order that our customers may test United States, one pound each of the MASTADUN and VICTORIA Carrots for $\$ \mathbf{I} .80$. Our five pound price, viz.: $90 \mathrm{cts}$. per lb., is absolutely the lowest price at which it will be sold in any quantity. Eight cents per pound can be deducled if sent by express or freight at purchaser's expense.

NOTE. Owing to the large size which these Carrots attain, less seed is required to the acre than of other sorts - $2 \mathbf{l b s}$. to the acre being sufficient.

N. B. G. Co's MAS'TADON Carrot. This is the heaviest cropping Carrot grown, yielding more tons to the acre than any other sort. The fiesh is white, crisp, solid and very sweet in flavor. It is a vast improvement on the white and green Belgian sorts which have been such favorites in the past, as it is not only much more productive but vastly easier to handle. The roots are short and very heavy at the shoulder, rendering them easily harvested. An important feature, also, is that they do not easily break in pulling or storing. Too much can scarcely be sald of their size and great productiveness. The roots frequently measure 15 to 20 inches in circumference, and 18 to 25 tons to the acre is not an extravagant statement as to the yield.

Price: Pkt. 15 cts., $1 / 4$ lb. 35 cts., $1 / 2$ lb. 60 cts., I lb. $\$ 1.00$, 5 lbs. $\$ 4.50$, by mail, postpaid. Deduct $8 \mathrm{cts}$. per $1 \mathrm{lb}$. if sent by express or freight at purchaser's expense.

N. B. G. Co's VIC'rORIA Carrot. This is the largest and unquestionably the heaviest cropping and most nutritious Yellow variety in cultivation. It is the largest and best form of Orange or Yellow Carrot known. The roots are remarkably fine, very symmetrical and of excellent quality, possessing high feeding properties. It is a heavy cropper on all soils, but especially adapted for strong or rich land. It grows fully half as much weight again per acre as the ordinary varieties, and as the roots grow more above the ground, it is much easier to gather the crop. This grand variety is sure to suit every one who grows it.

Price: Pkt. 15 cts., $1 / 4 \mathrm{lb} .35 \mathrm{cts} ., 1 / 2 \mathrm{lb} .60 \mathrm{cts} .$, I lb. $\$ 1.00,5$ lbs. \$4.50, by mail, postpaid. Deduct 8 cents per lb. if sent by express or freight at purchaser's expense.

\section{Meadow Lawn Stock Farm.}

N. P. CLARKE, Proprietor, IMPORTER AND BRRHDER OF

Clydesdale Horses, Short Horn and Guernsey Cattle. ChOICE Young STOOK For SALE.

ST. CLOUD, Minn., Oct. I 2, I 893

NORTHRUP, BRASLAN, GOODWLV CO. Minneapolis, Minn.

GENTLEMEN:-You ask me to express my opinion as to the value of Carro for feeding stock. In reply, would say that no one who feeds stoel can afford to be without them. I feed each year Mange Wurzel, and Tuta Haga, and regard them very highly; but Carrot I comsider imdispensable. I increase my acreage of Carrots eac year; and believe I secure better proportionate results from the use than from anything else f feed.

As to varieties, mothing cam be better in point of quality an rreat productivemess, than your VICTORIA (yellow), an NASTADON (white). I do not yet know which of these Carrots is the bes and so use them both, but I have never yet seen them equalled.

In this connection I am glad to express the unqualified satisfaction yo seeds have given me in the many years I have traded with you. Very truly yours,

N. P. CLARKE.

\section{"FIRST PRIZE IN NORWAY."}

"My cousin in Norway, to whom I sent some Carrot Seed fror your house, writes me that he took first prize at their fair with th Victoria Carrot, and that they attracted great attention on accoun of their size and solidity." - NiLs Michelet.

\section{"THE FINEST CARROTS I EVER SAW."}

Jaсов Gintz, Huntington, Ind., writes: “You sent me Mastadon Carrot Seed last year. They are the finest Carrots I ever saw. I had several weighing $3 \frac{1}{2}$ lbs."

"Yielded Double the Crop of any other variety.'

H. E. Butrers, East Exeter, Me., writes: "Last Spring you sent me $1 / 4 \mathrm{lb}$. of your White Mastadon Carrot in place of Victoria. I gave then ordinary field culture and planted them side by side with White Vosges Long Orange, and Oxheart. The Mastadon yielded at least double the crop of any other variety. Most of them grew a foot long or more, and measured $31 / 2$ to 4 inches in diameter, and weighed $21 \%$ lbs. or more They are far ahead of any Carrot I have ever tried, unless it be the Victoria. I took first premium on a bushel of them at our County Fair. Every one says they are the finest Carrot ever seen here. They pull without a fork, and come up clean and handsome. Your other seeds have always given good satisfaction."

\section{"TOOK FIRST PRIZE."}

"I received First Prize on the Mastadon Carrot from the Seed purchased of you last Spring." - R. U. LEwis.

NOTE we introduced the VICTORIA CARRO'T N 1 . in 1890 , and it met with a most extraordinary sale Since that time, we have never been able to supply over 25 per cent. of the demand, being obliged each year to return money to hundreds of disappointed customers.

The same statement applies to the MASTADON CARKOT excepting that having been more recently introduced, it has not becom so widely known as the VICTORIA amongst those who annually sow large quantity of Carrots for feeding stock. We had sold ever pound of these two Carrots last year before th first day of February.

Those who wish to engage Seed should apply early in order to prevent disappointment. 


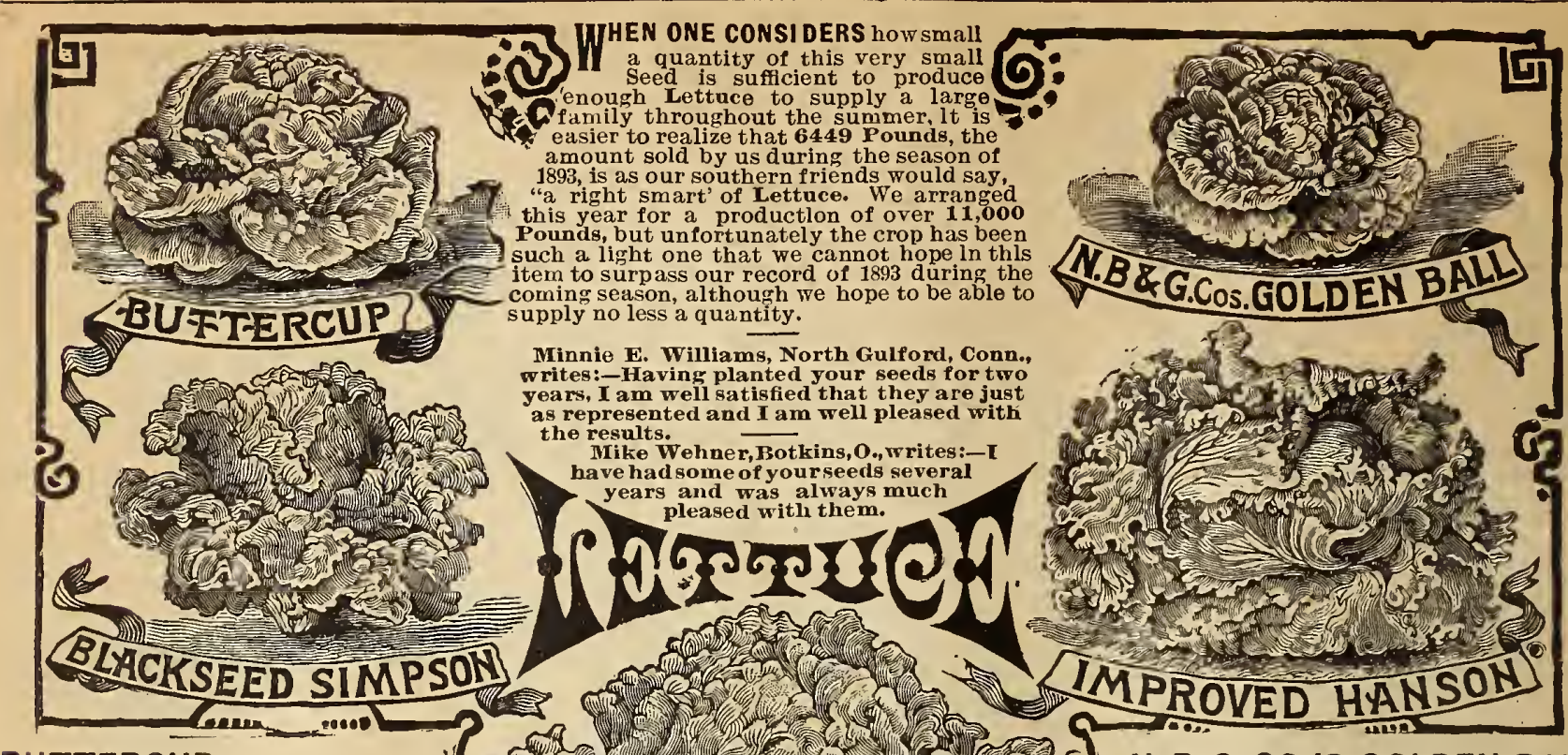

BUTTERCUP.

This new lettuce is equally fine for

winter and summer use, as well as for
forcing; it forms very solid heads, is quite early, and for tenderness and will hold a foremost place among the
newer lettuces. Pkt., 5 cts.; oz., 15cts.; BLACK-SEED SIMPSON.

One of the best varieties either for
forcing or for early showing out of doors. Very popular with market ib., 25 cts.; $1 \mathrm{~b}$., 75 cts., postpaid. WHITE-SEED SIMPSON. Pkt., 5 cts.; oz., 15
lb., 70 cts., postpaid.

\section{TILTON'S WHITE STAR.} This variety will commend itself market gardeners on account of its
very large loose heads which are oo
most excellent flaver. It is a splendid keeper and shows to great advantage
on the marketstand. One of the very
best for forcing under glass and for early planting in the open ground.
Pkt., 10 cts.; oz., 20 cts.; $3 / 4 \mathrm{lb}$., $3 \mathfrak{3} \mathrm{cts}$;

\section{DENVER MARKET.}

It is an early variety of head lettuce, either for forcing or open ground. It wo to seed. The leaves are beautlfulIy marked and bllstered (like the tender, and of excellent flivor. By
these blistered leaves it distingulshes
itself from any other kind of lettuce resembles somewhat the "Hanson." 20 cts.; $1 / 21$ lb., 40 cts.; ib., $\$ 1.00$, postpaid

Miss Lydia Bailey, Romeo, Mich., writes: -1 wish to say to you that the appreciated here as much better for baking or soup than the White Beans usugood as Limas.

Jane Foster, Corning, Kansas, writes: - "This is my thirdvear of buying seed of you and I have always had good success with them."

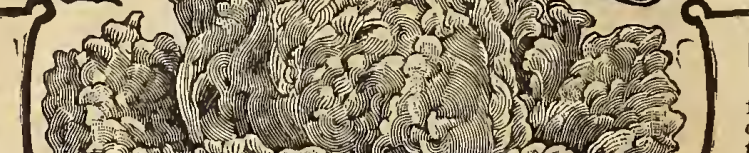

N.B.G.CO.'S GOLDEN BALL N., B., G. Co.'s Golden Ball is a novelty color assia, distinct from all other sort the same beautiful color throughout the season, which enhances its value as a seller is the acme of perfection in the list of lettuces, and a variety that we can especially recommend for forcing or early spring crop. It is long stunding, remalnvariety. Pkt., 10 cts.; oz., 20c.; $1 / 2$ 1b., 35 cts.; lb., \$1.00, postpaid. IMPROVED HANSON.

We have a very fine ptock of this varlety, and can recommend it as one of the iety of the largest size; solid, sweet, tender and crisp throughout, and entirely free from any bitter taste; for home use, 15 cts.; $1 / 4$ lb., 25 cts.; 1 b., 75 cts., postpald. GRAND RAPIDS.

This ls a new varlety, orlglnated near Grand Rapids, Mlich. Forms a fair sized, quality, and so far as known, free from rot, and will keep from wilting longer while exposed for sale than any other variety crimped and frilled thin but of a very upricht and habit it may be planted very closely. It is of extrenely rapid growth. These gualities have enabled the market garare now about 50 large greenhouses engaged in ralsing it for market at that and New York and dispose of it at profitable figures over all competitfrom the orlginal seed. Pkt.., $10 \mathrm{cts}$. oz., 25 cts.; $2 / 1$ lb., 40 cts.; lib., $\$ 1.00$ postpaid.

Mr. J. W. Emery, Loveland, Ohio, writes:-Your seeds are fine. Must try them again. The peas were splendid.

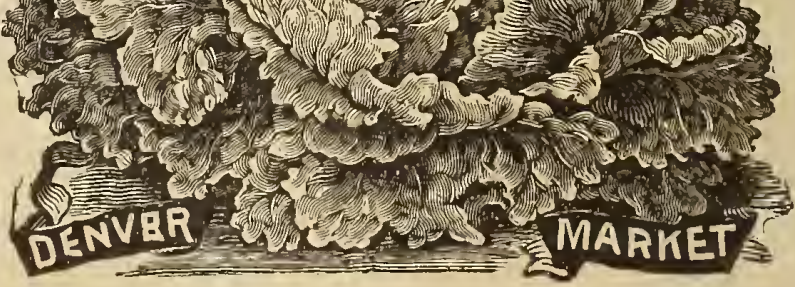

Mrs. Louise Ecklor, Pepin, Wis., writes:-This is my third order for seed from you and 1 hope 1 shall be as well pleased in the future as in the past. find I have better success with your seeds than with any other I ever tried.

If you have a small patch of ground, no matter how small, there is no way in which you can get as much satisfaction out of it as by growing Lettuce, Radishes, Etc. Their greatest merit consists in being Fresh and Crisp. 


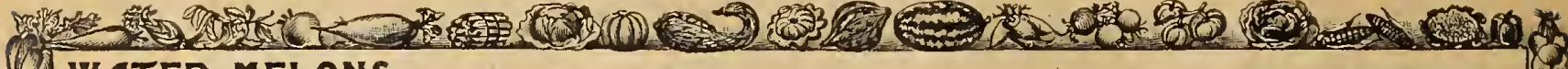

W W ATER MELONS. Our sales for $1893 ; 3880$ lbs. As from 4 to 5 lbs. are used to the acre in seeding, 3880 lbs. would 5 . 1. plant about 000 acres, which acreage produced a good many water melons. Although 3880 lbs, is a good deal of water melon seeds, we

5. freely acknowledge that considering the enormous consumption and popularity of the fruit, that our sales on this item do not seem as large

1. as they should be, when compared with the business done by us in other important items. We cannot account for this in any other way,

(7) than that water melons being so largely a product of the South, large planters think that the seed from such a Northern point as Minne-

apolis would not produce as large and fine melons as they desire. If such an impression exists we want to correct it by saying that while

(fi we can grow as fine melons of any variety in Minnesota as can be produced in any state, the greater part oi this seed is grown in another (1) state where the soil is lighter and the seed can be more economically saved.

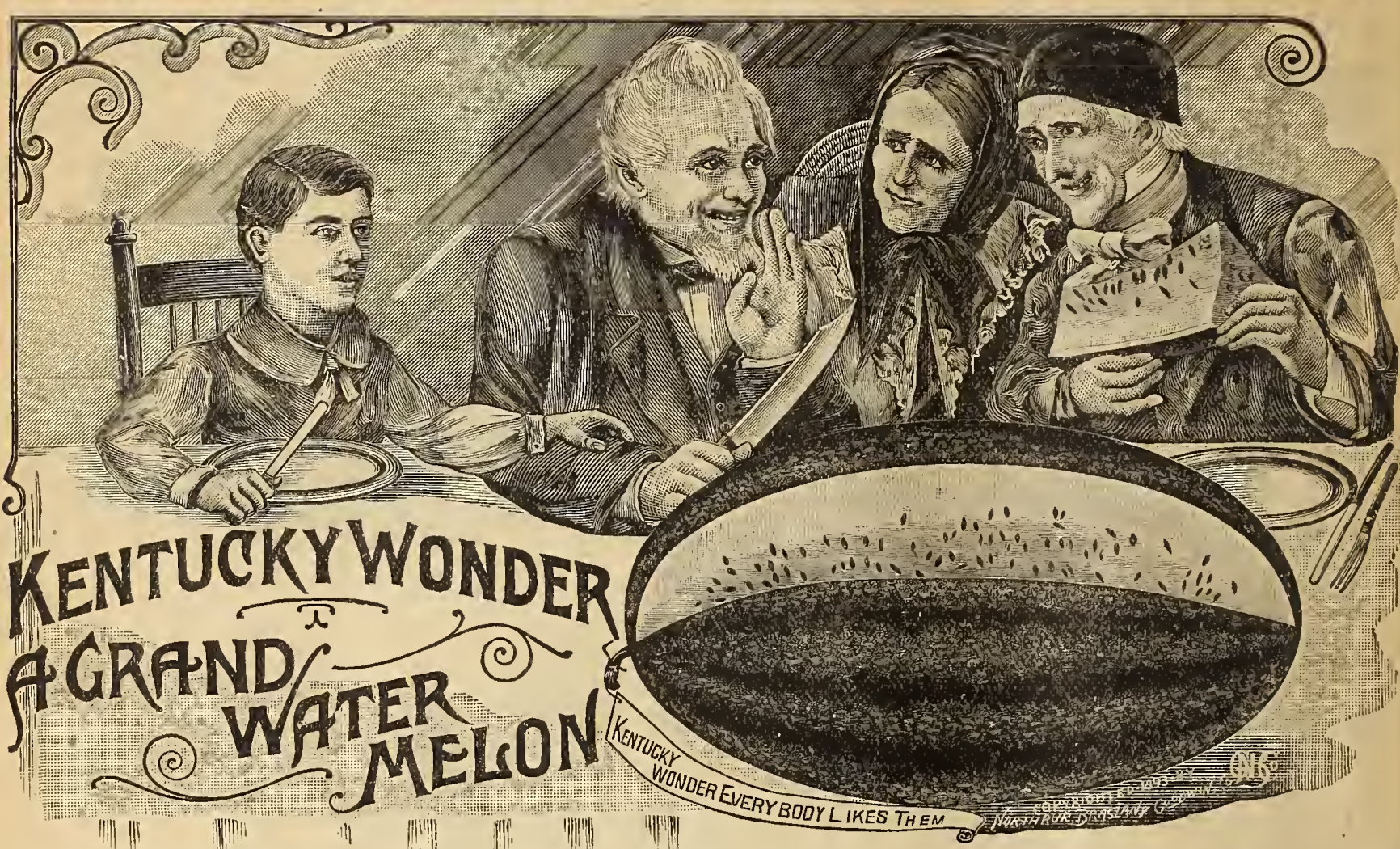

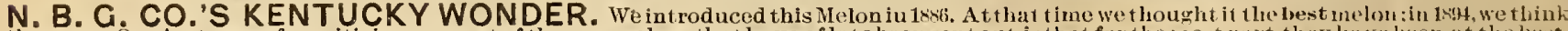

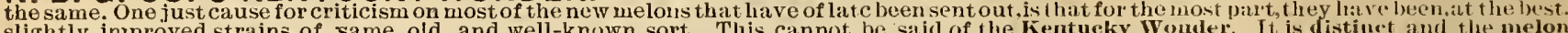
slightly inrproved strains of same old and well-known sort. This cannot be salid of the kentueky Wonder. It is distinct and the melon itself proves it. In shape, it is oblong, attaining a good size, skin dilrkgreen and heallifully marked. Flesh, a beautiful rich searket color. crisp, rich, sugary, always firm and solid, never mcaly or tough. Kentuck y Wonder has won first prize over such well-kinown itnd popular

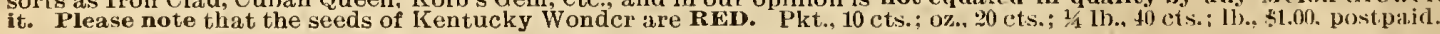

MAMMOTH IRONCLAD. Of oblong shape; with skin handsomely striped, and flesh of most deliciously rifh. surtry liaror; the heart is very than any other, producing under ordinary cultivation, melons averaging fifty to sixty pounds in weicht: have been wrown fo weigli orer 100 pounds with extra cultiv

KOLB'S GEM. Melon dealers say that as a shipping melon it has hardly au equal. It is in early varnety that is lampely rrown. par-

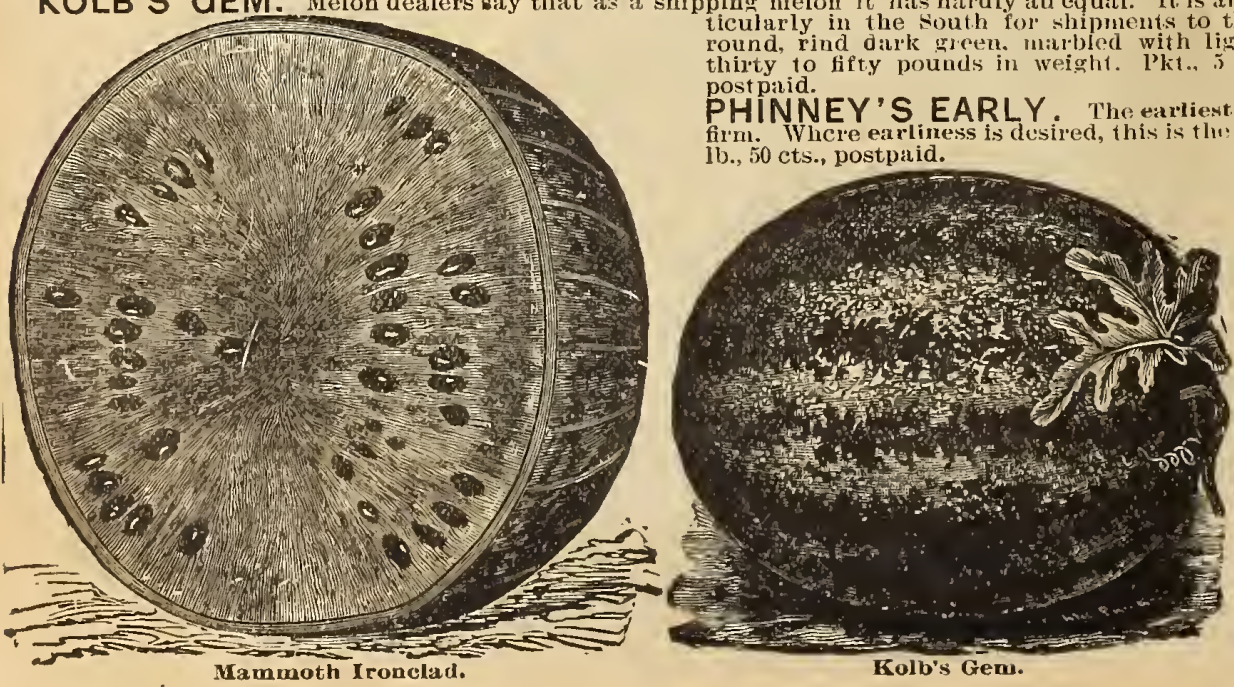

ICE CREAM OR PEERLESS. of medium sime e:arly (true white seedind), a very popular vilriety, and one of

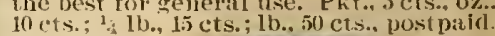


MELONS, MELON PEACH, MUSTARD, MUSHROOMS.

THE DIXIE. Thls now waterinelon has excelle ni merls and we cál (1) hlp ing melon grown, being eve larger, eartier and Parmore productive than the Kolb's Germ, which lias heretotor best meloul for shipplng. lit is of a very tine appearance, be lag much darke than kolbs Gem and more be a tifully striped; it is longer nd extremely hat dy y is unexcelled. beIng sweet, juley and tender. Another very mportant polnt ist prodnctiveness, hav Ter tho tren il in tock int the folldwoz, $10 \mathrm{es} ; 1 / 111$.. $20 \mathrm{c}$. Velon, Colorado Preserriu lakes beautlful clear, nearly 1 ransparent preserves of pare entery citron; vely produe15 cts. $131 \mathrm{~b}, 0$. $\mathrm{Ib}_{\text {i. }} 60 \mathrm{cts}$, post paid. wh ofter por ed at the same prier. cealesl preSOUTHERN GIANT CURLED MUSTARD This mustard is very highly esteemed che south, whrest fall. and the plint whlch grow nbout. reet high and for slx of whlch will fil an ordinary balrel 2w.: ilb. 90c.,post pait
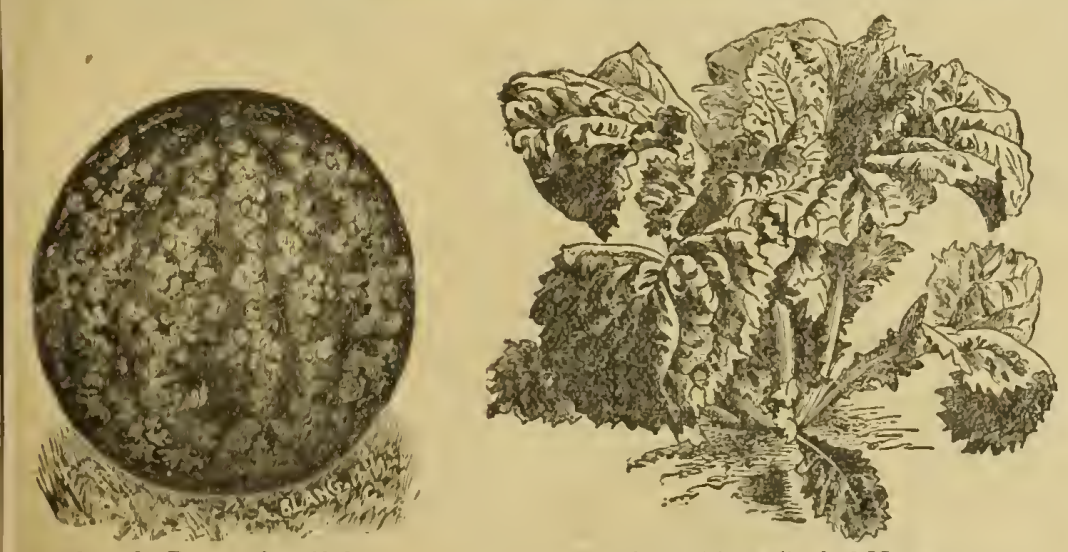

\section{VALUE RECEIVED, WITH USE.}

\section{atch of}

sort.

a portlon of it every day and pay Full Market Price in EGiG.
SEM I NOLE.

Flesh abrlllant car-

mine, very solid, of a

rlnd thln, but so

nugh as to make lt a

most superior ship

melon. In slze, pro-
ductiveness and do-

all the fine quiallities

that go to make up a

cts.; $0 \%, 10 \mathrm{e} \mathrm{s.;} 1 / 1 \mathrm{~b}$

DARK ICING.

True, Rlud very thln but strong. mirly shipping sort. Oul seed his been oz., 10 ets.; $1 / 41 \mathrm{lb} .15 \mathrm{e}$. THE MELON PEACH.
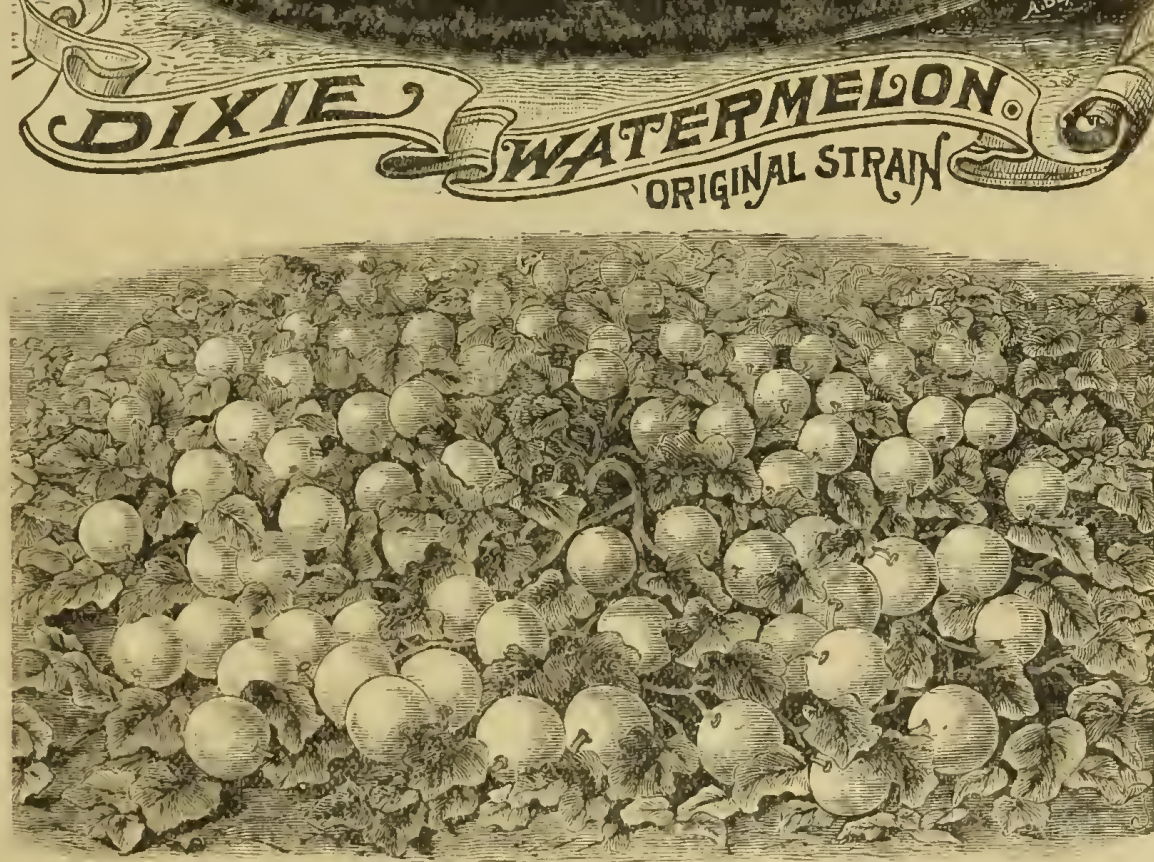

The pruit is about

the size of a large

and of a bright or

first ripen they are

uite hard and have

pich flavor. When

ipe the fruit Palls le li is very firm with enter, ind when aken out they much or sweet pickles. hey are superb; a or $i$ itte semtheir flavor, and is us-

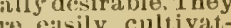
. wonder cully prosed in every way ln the hey are not usually cellent simply to cts. postpaid

MUSHROOMS. With lntelligent care and miny lo made to paly hand

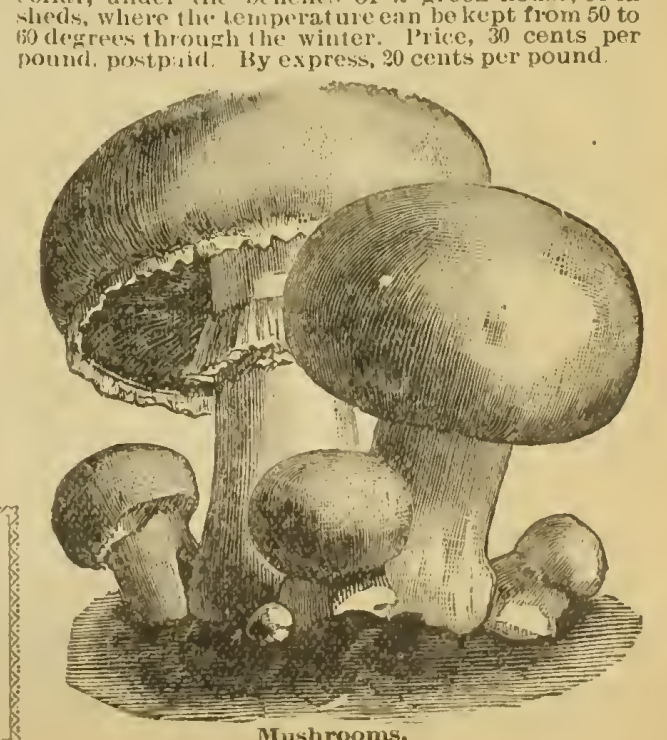




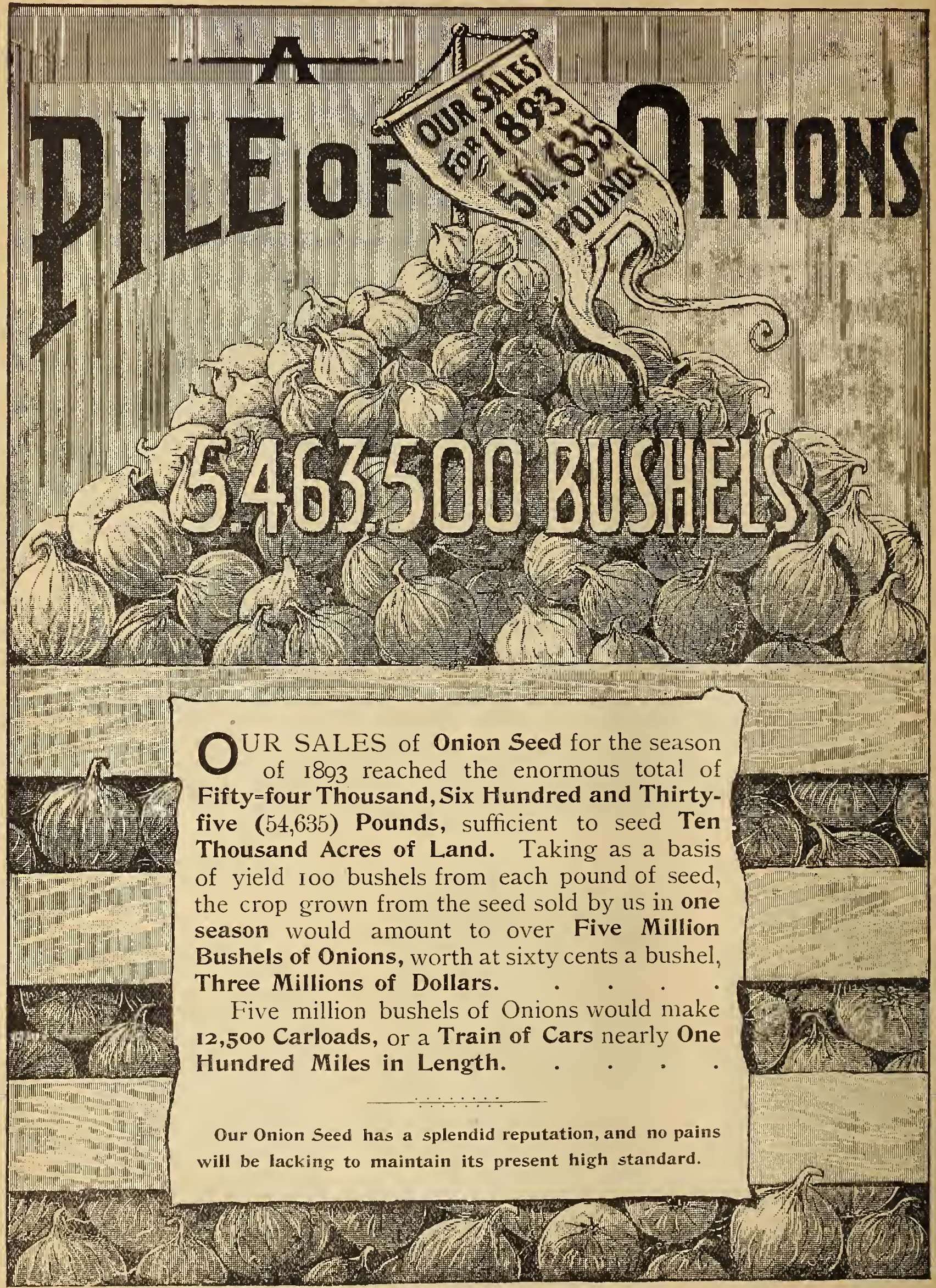




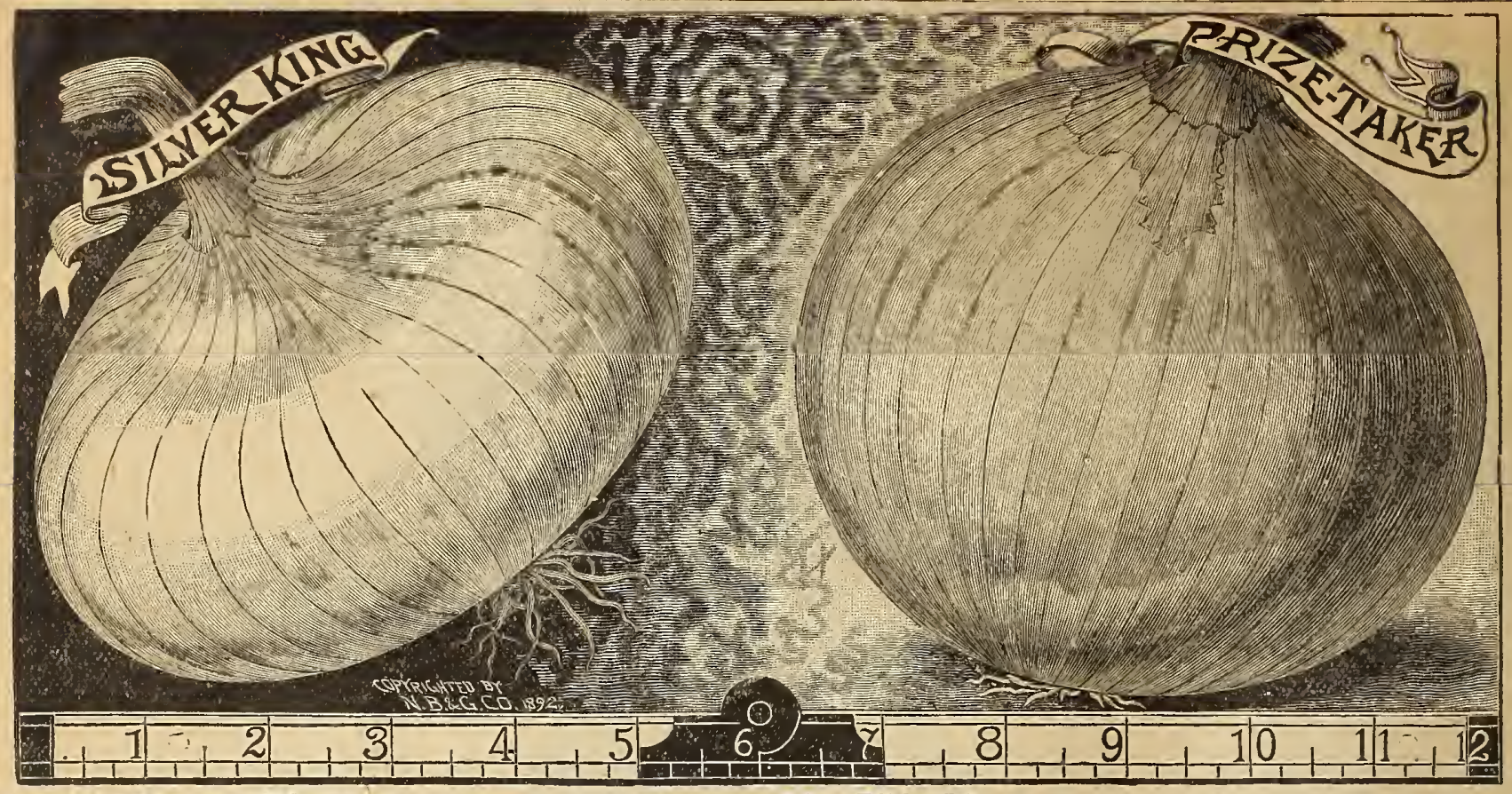

MAMMOTH SILVER KING. In appearance this is the most siriking onion grown. We hardy know which to commend the most its sweetness, tenderness and mild flavor. These quallties miake it the home table it is unsurpassed. Although the euliest of the large Italian sorts, its size precludes its satisfactory niaturity in the exBERMUDA ONIONS. These onions grow to an immense size grained, of mild and pleasint flavor. It will grow an onion from one to one and a hale pounds from seed, but to attain the full size the GIANT ROCCA. A fine globe shaped val.iety, growing to immense size, often at
taining a weight of 3 lbs skin light brown
Pling SPANISH KING. This handsome vaOnion, the flesh is remirkably firm and of tures carly. The skin is of a transparent. WHITE QUEEN. Remarkable for 1ts small. iluch used for pickling Pkt., $5 \mathrm{cts}$. WHITE BARLETTA. This variety 1 ncss. It is earlier than the White Queen. It $11 / 4$ inches in diameter and $3 /$ of an inch thick, with fincly formed bulbs, slightly fattened at its use as a substitute for onion sets. An ex-

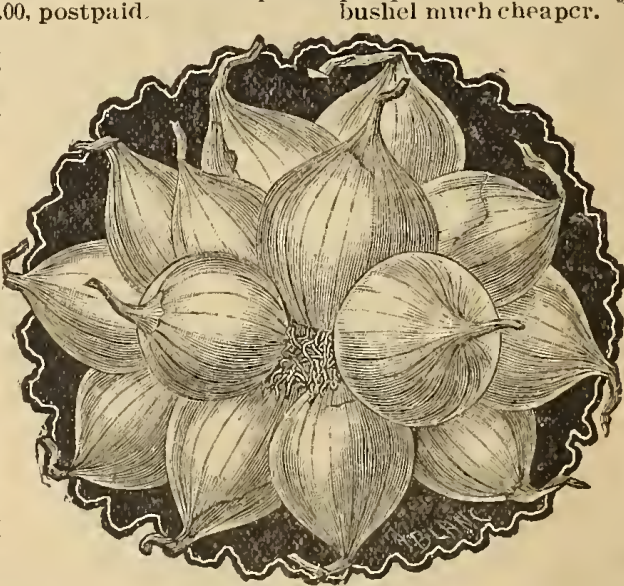

PRIZETAKER. This onion is very closely related to the Spanish King, but is really in improrement on thit favorite sol t, owing here has resultcd in such increased size and greater solidity as really to entitle it to be classed as a new val'iety. It is perecty globe the onions always ripen up hard. An excellent keeper, exceedingly fine Havor, grows to an enornous si\%e. Onions weighing five pounds having been grown froll seet the iirs $y$. ONION SETS. They furnish large onions EARLY, as well as lirst greell omions for table use. At prices quoted we send by mall, Write for special rates before placing order.
wh WHITE MULTIPLIER ONION SETS These have been in existence miny years in wintered in the cellar, but never grown in cently. The lirgest of the sits if allowed to through the summer makes an onion of all, multiplying liberally for a nother year. are very early. Pint, 20c.; qt., 40c., postpaid. WHITE BOTTOM SETS. lint, 20 YELLOW OR RED. Pint, 20 cents; TOP SETS OR BUTTONS. Produce large onions earlier tlian froin EGYPTIAN OR PERENNIAL. When once set out, they come up year after year. 15 cts.; quart, 30 ct

POTATO ONION. Valuable for early

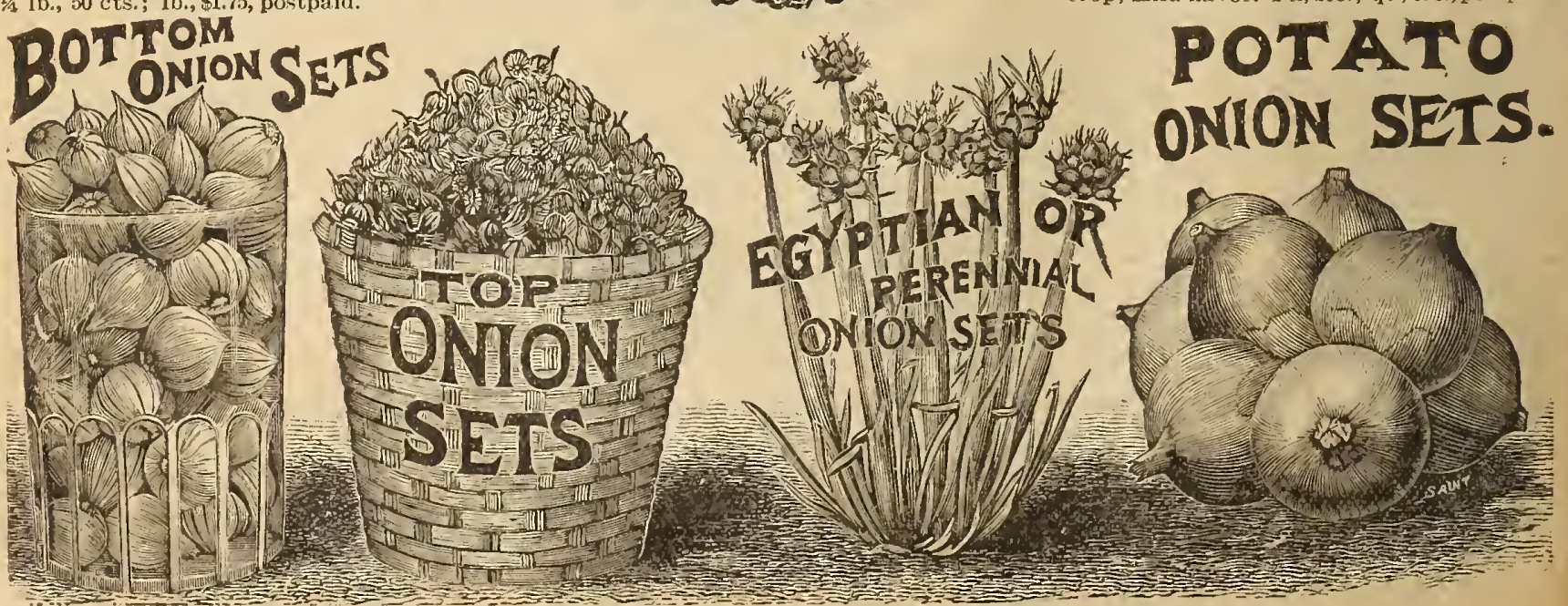




\section{MOSS CURLED PARSLEY}

CEs? thos.

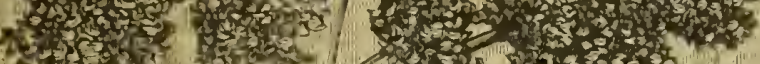
$100 \%$

(3) 3) OST 3 CHAMPION 30. 30 . औh $\frac{1}{60}$

PLAIN OR SINGLE

and for garnishing; for flavorlug, the creen leaves are used, or

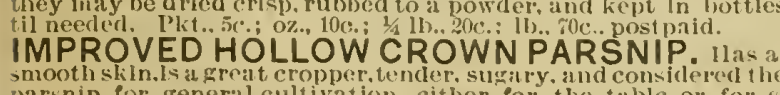

PROCOPP'S GIANT PEPPER.

formy to an very large size. of

CORAL GEM BOQUET.

of coral

pods

CARDINAL.

CELESTIAL.

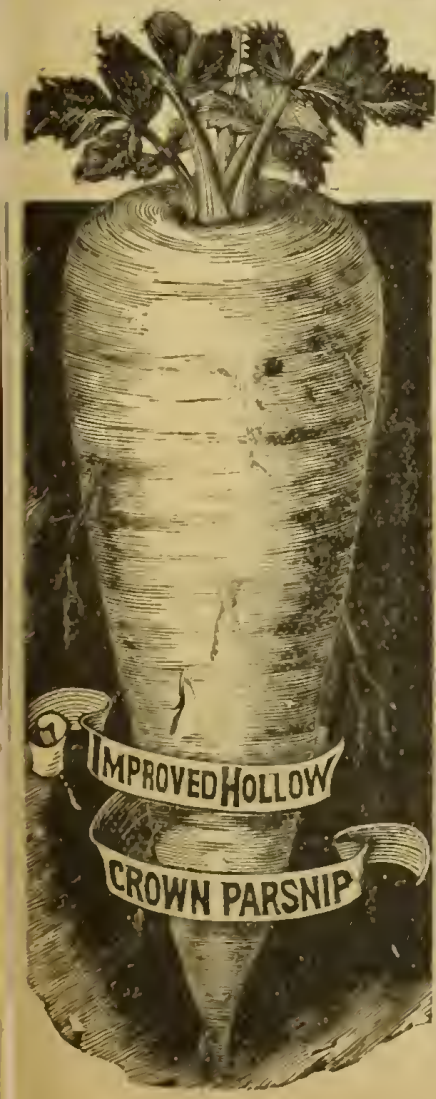

BLACK NUBIAN

GLDEN DAWN
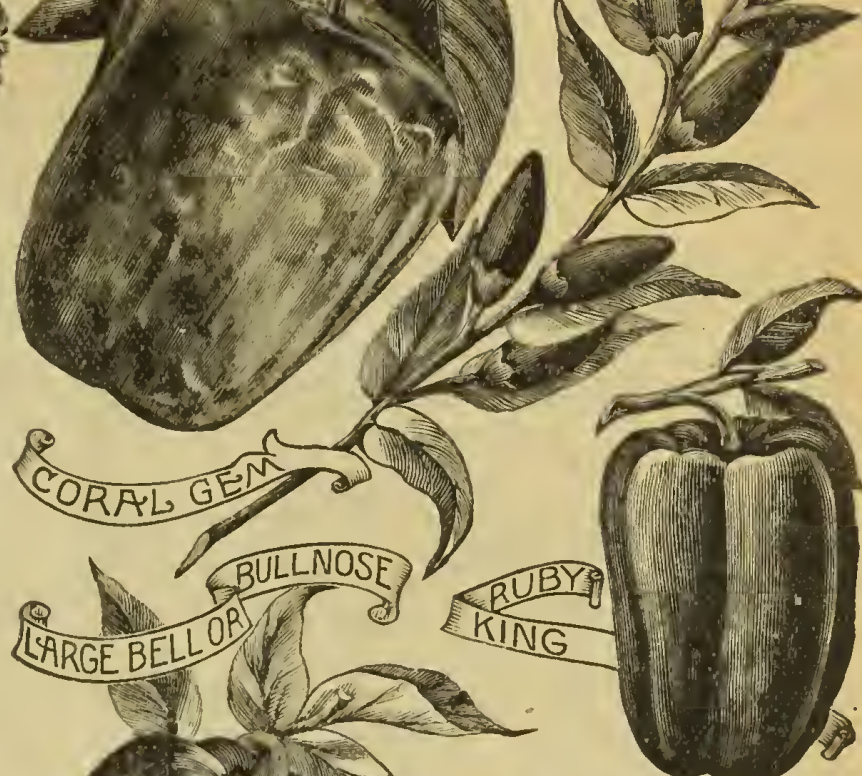

LARGEBELLO KKING
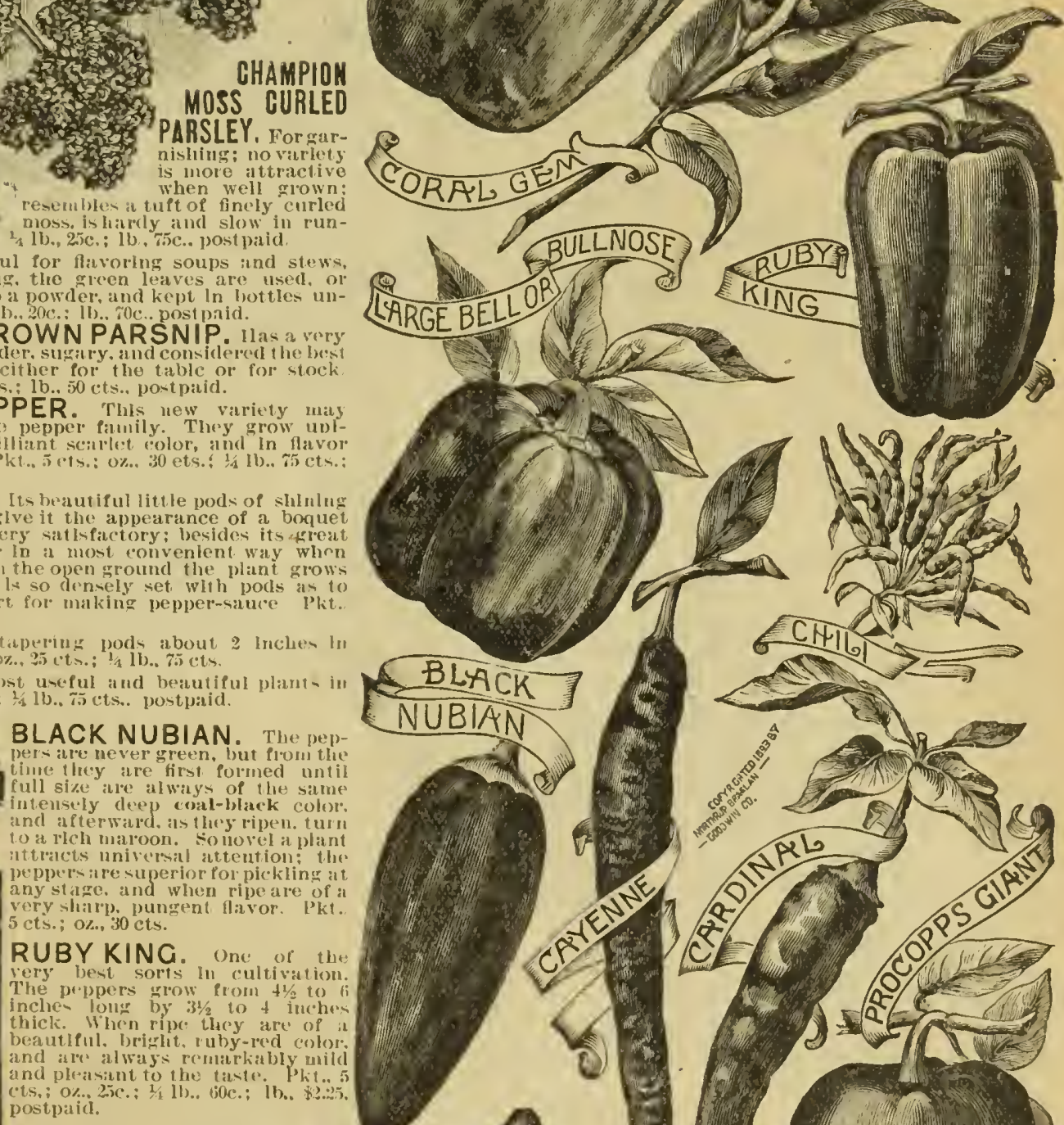

LARGE BELL OR BULL NOSE

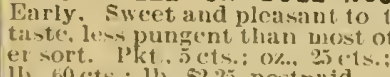

RED CHILI.

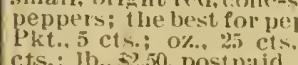

CAYENNE.

GOLDEN DAWN.

his is arimht golden yellow, coler

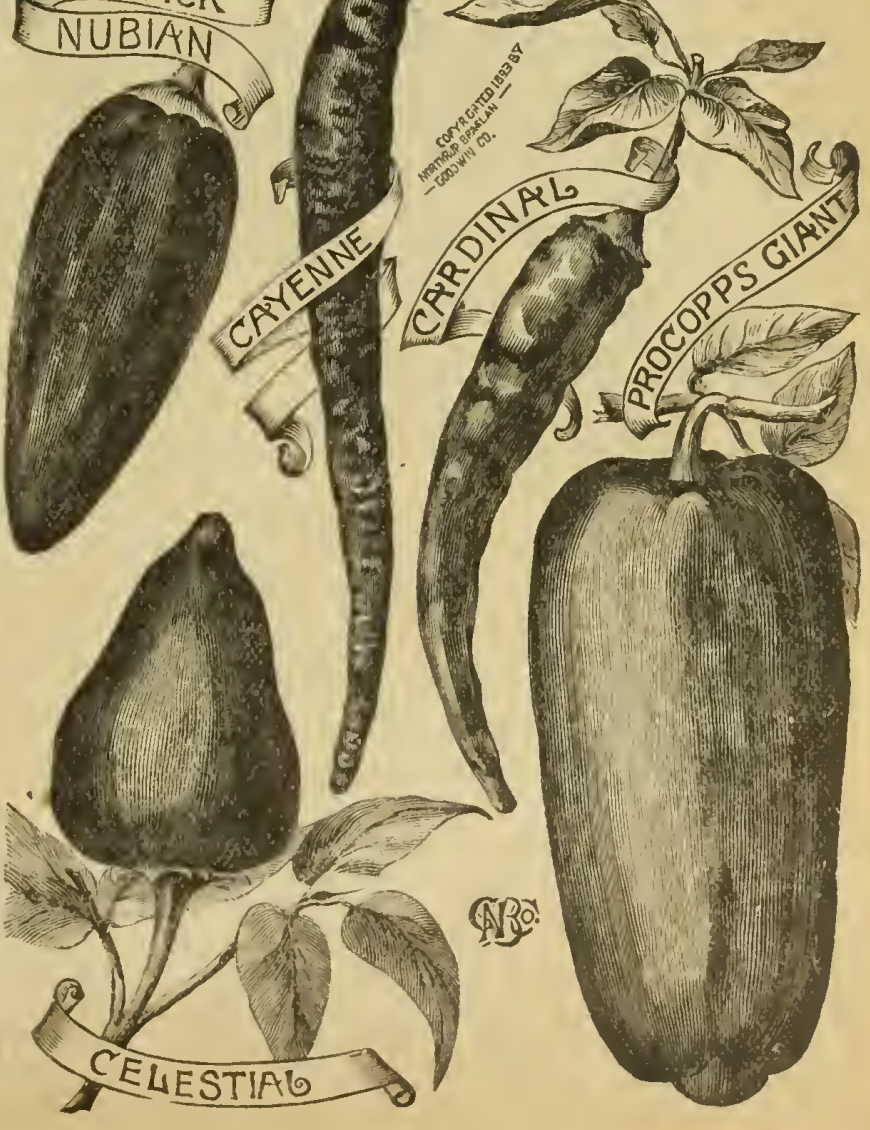



PEAS. Our Sales for 1893, 14,166 Bushels. At two bushels to the acre, the above quantity would
plant, say 7,000 acres. The product of this acreage should not fall far short of One Million Dollars in value.
We should have been able to report much larger sales on Peas but for the heavy rains of 892 which
totally destroyed many of our best fields. This year, drouth has done even greater harm, with the result
that the Pea crop is the lightest known for many years. Prices are sure to rule high, and planters will do
well to secure their Seed Peas before good stocks are exhausted.

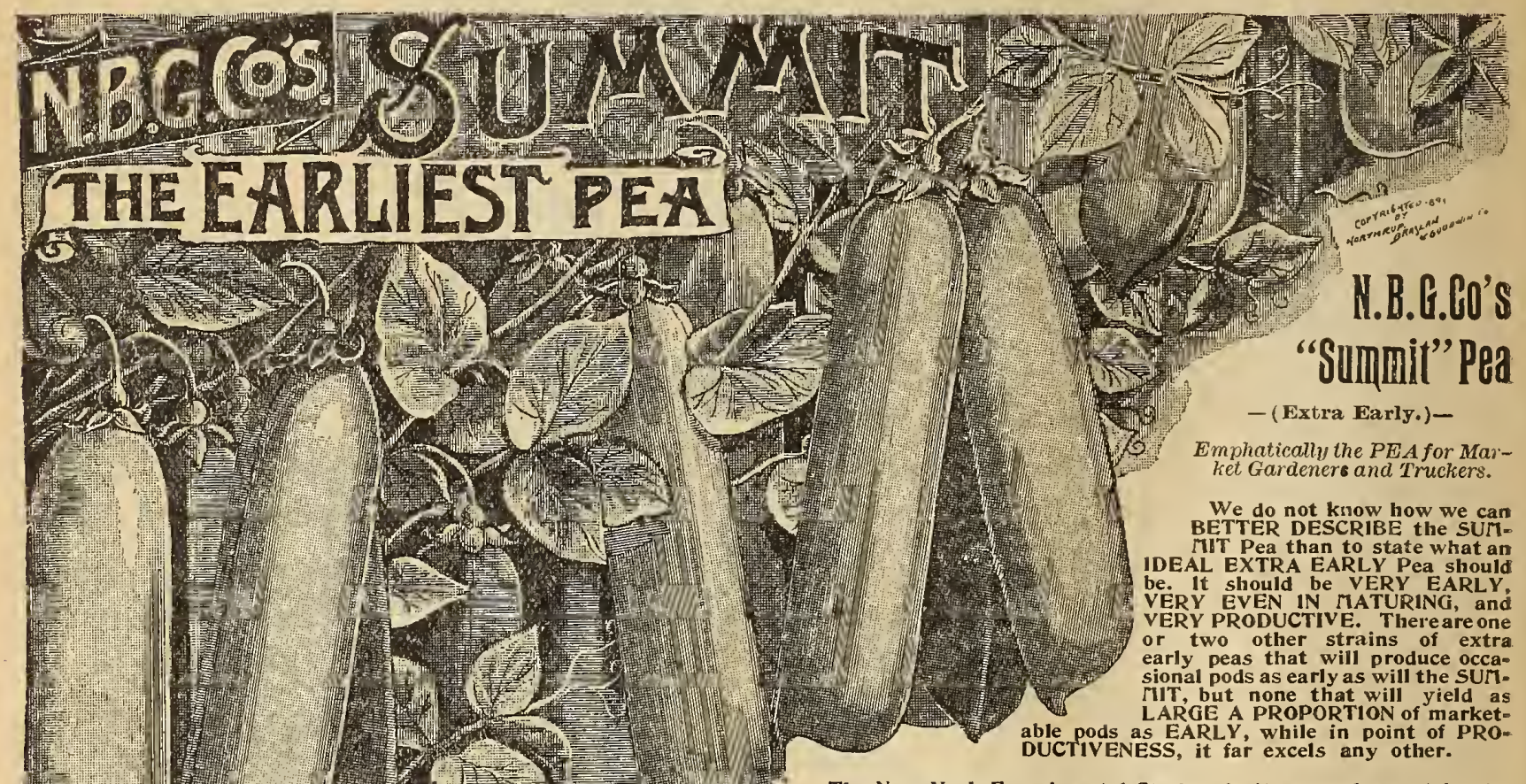

The New York Experimental Station, in its annual report for the year 1889 , characterizes the SUMMIT pea as "ENORMOUSLY PRODUCTIVE" (see page 318 ), and in its comparative table shows that or 48 more Peas to the 100 Pods Than Any Other Variety Tested,
Early or Late.

Since the first year we introduced the SUMTIT Pea, we have never been able to supply the demand for them; our orders for one season being over Five Times the quantity we could furnish. On account of the unfavorable growing season, our crop this year is very limited; but we hope that as many as possible may try them, so that another year they may have personal knowledge of their merits by actual test. We will fill orders as received as long as stock lasts. Pkt., 10 cts.; Pints, 25 cts.; Quarts, 40 cts., postpaid. Ey express or freight, Quart. 25 cts.; Busliel, \$5.00. ALASKA. First Early; Height 2 Feet; Seeds Blue. Early and very uniform in growth.
The dark green color of the pods makes it extremely desirable, as it can be carried long
distances without losing color, which quality, combined with itsearliness and uniformity
of ripening, makes it one of the most desirable extra early peas for nairket gardening. AMERICAN WONDER. (GENUINE.) Second Early; Height 10 inches; Seeds H AMERICAN WONDER. ( GENUINE. ahout 50 days. It is the first early among the green wrinkled sorts: needs no brushing; very productive and
wine flavored. An excellent variety to plant for succession. Pkt., 5

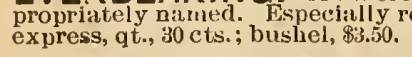

FIRST AND BEST. First Early ; height $2 \frac{1}{2}$ feet; seeds white. One of the earliest. A standard sort. Pkt., 5 cts.; qt., 40 cts., postpidid. By express, qt.. 20 cts. bushel $\$ 3.00$.

LAXTON'S ALPHA. Second warly; height $21 / 2$ leet; seeds rreen, wrinkled. The earliest Wrinkled pent known; seeds iruch indented, very tender, and of delicious fiavor; produces tine, respect. In our opinion the sweetest ind tinest liavored early pea grown. Plat., 5 cts.; qt., 50 cts.,
postpaid. By express, qt., 35 cts.; bushel, $\$ 4.50$. MAUD S. First Early; height 2 feet; seeds white. A Canadian extra early, of great merit. Even in maturing; productive. Pkt, 5 cts.; qt., 45 cts., postpaid. By express, qt., 25 cts.; bu., $\$ 4.00$.

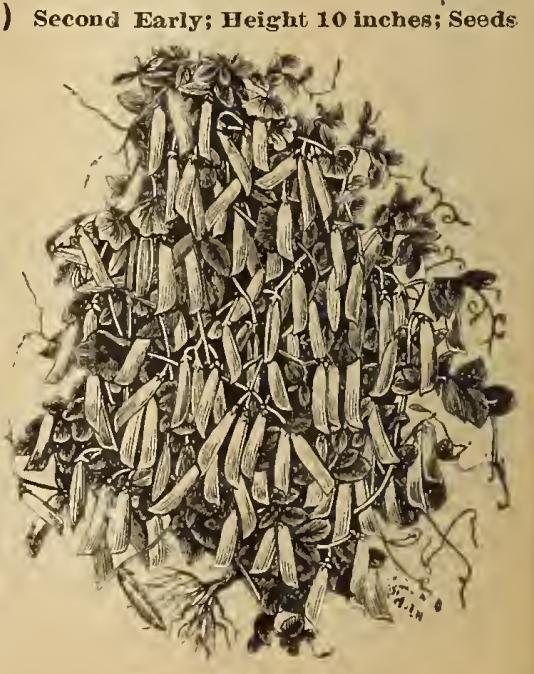

Preminn Gem Pea. 


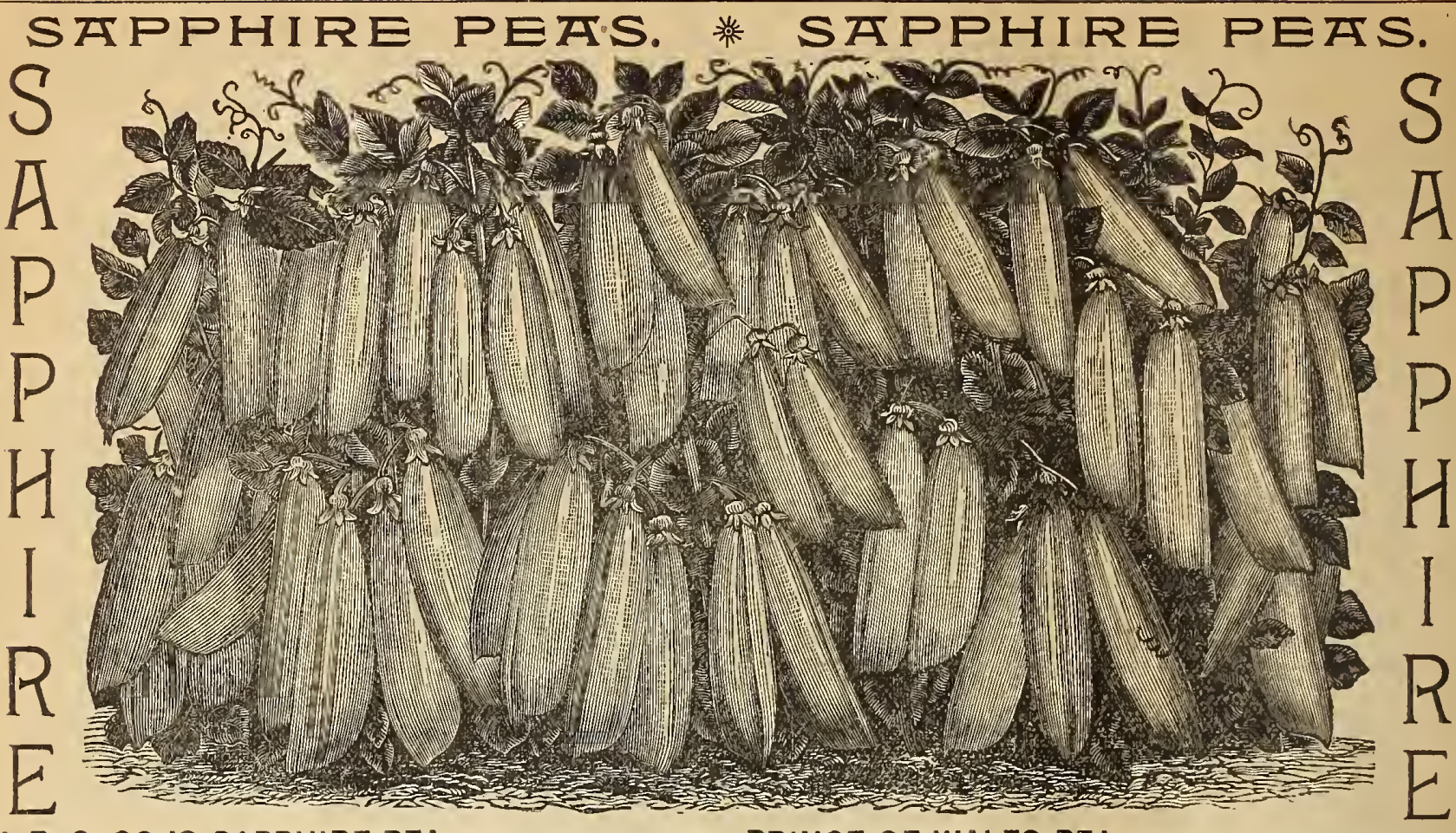

N. B. G. CO.'S SAPPHIRE PEA, We can unhesitatingly

PRINCE OF WALES PEA. Several years ago one of our

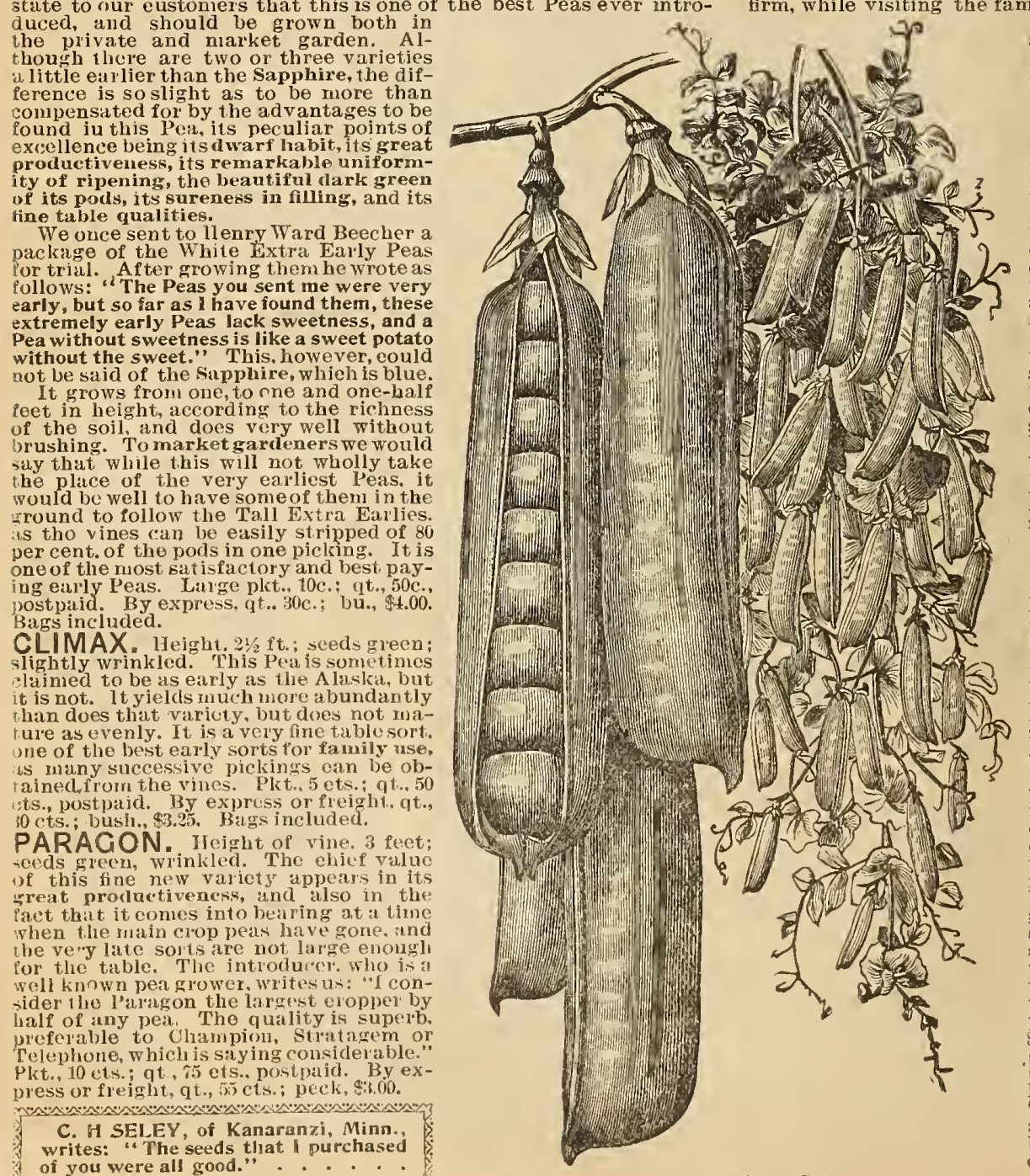

Was struek by the fine appearance of somie of the Peas being brought in by the al ways met with a rapid sale. On inguiry they were found to be the PRINCE of vestlgation showed them to be the most popular of any variety, both to the prolucer and to the consumer. To the producer beeause of the large pod, immense. productiveness, freedoun from mildew. and to the peeuliar quality of holding exposed in the open market for several days; to the consumer on account of amount of slielled peas and the large a given quantity of pods. We purchased a quantity of the seed, feeling sure that seized upon by the trade. Since that time we have anlually grown eonsiderable quantities, but we are free to say that the seed has not net with the ready sale we had expected, or that the variety merits: to England.where itstill usually been sent popular market garden Pea, as it was ten yeurs ago. We have from tine to time sold these peas tomarket fapdenursand privat planters to Those a ttention we were able to personally bring the merits of this pea. an Pea, that they hive not demunded it again This leads us to believe tlat it failure this leads us to believe tliat, its the consumers of this country has been because it had not been properly brou to their attention. We hope throu this year each one of our customers who plant peas will give it a trial, as we know they The Prince of wales is what might properly be called a main erop pea, comephone ind Stratagem. A verage height of vine, $21 \%$ feet; seeds very la rge helght wrinkled. The pods are large, yellow, mot arge as the two sorts just nanied. a will produce more pods from a Gen quantity of seed than any othe herer anmer of thus rendering it alike valuable to both the consumer. Try postpaid. By plit., 10 ets.; qt., 6 cts., HORSFORD'S MARKET GARDEN Second ' Those who want a good early Pea, sweet and productive, cannot do better thin to ets.; qt., 45 ets., postpaid. By oxpress, 

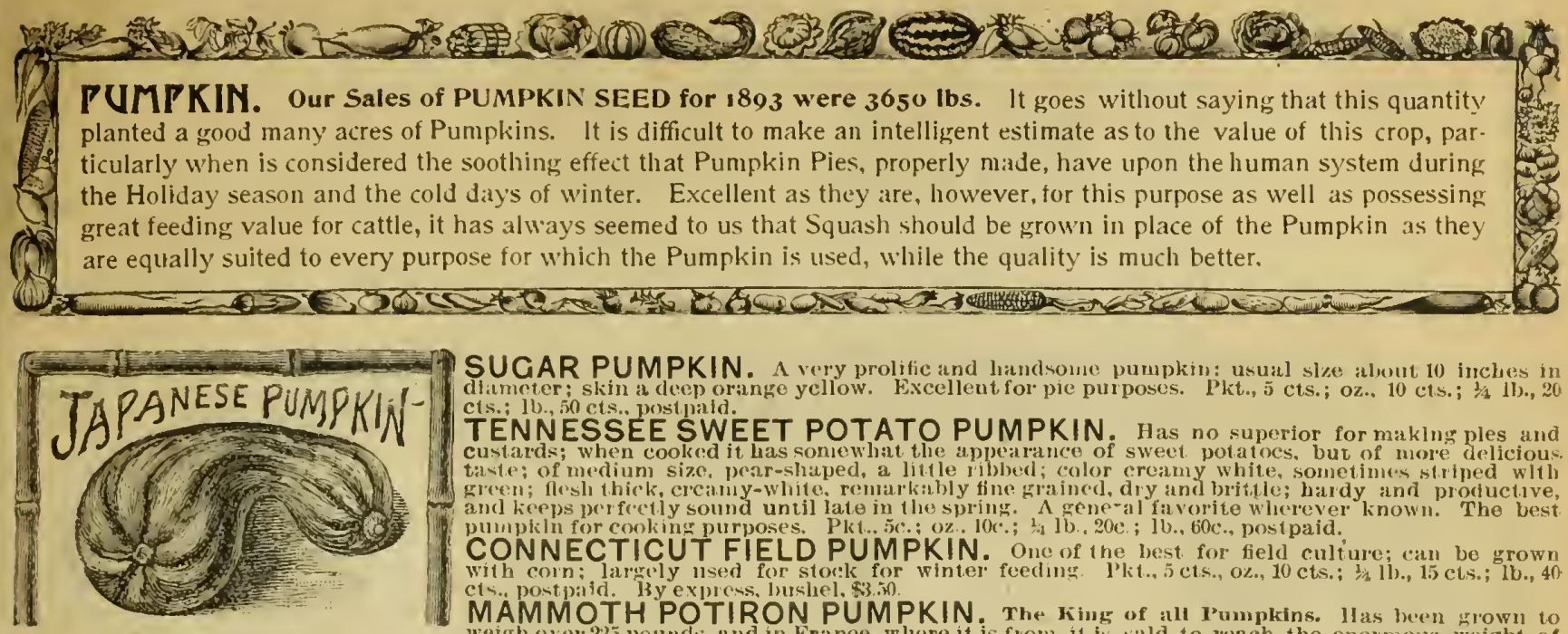

SUGAR PUMPKIN. $\Lambda$ very prolitic and landsome pumpkin: usual slae alvout 10 inches in

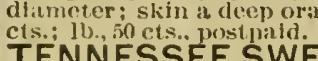

ENNESSEE SWEET POTATO PUMPKIN. Has no superior for making ples and tavte; of mediun sized it has conewhit the appearance of sweet polatocs, but of more delicious

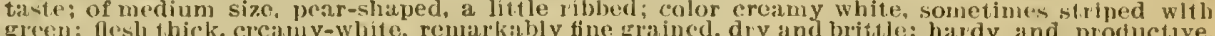
and keeps perfectly sound until late in the spring. A gene-al fivorite wherever known. The best CONNECTICU Furposes. Pliti..5

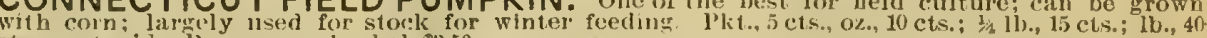
MAMMOTH POTIRON PUMPK

Has heen grown to Wen Japanese l'umpkin.

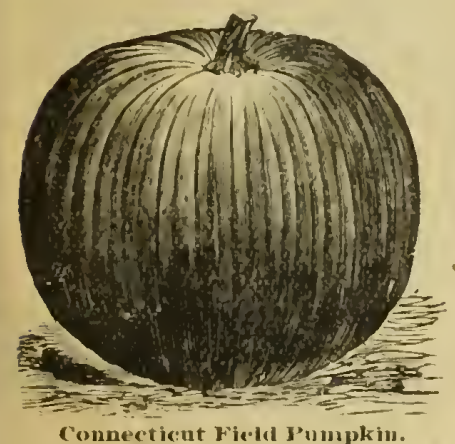

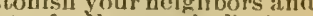

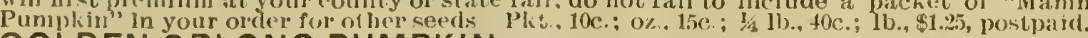

GOLDEN OBLONG PUMPKIN, The fruit when young is dark green, and changes to a rich folden yellow as it ripens The flesh is lisht yellow in color. rich and fine guility lis is very prolifie LARGE CHEESE PUMPKIN.

JAPANESE PIE. This remarkah
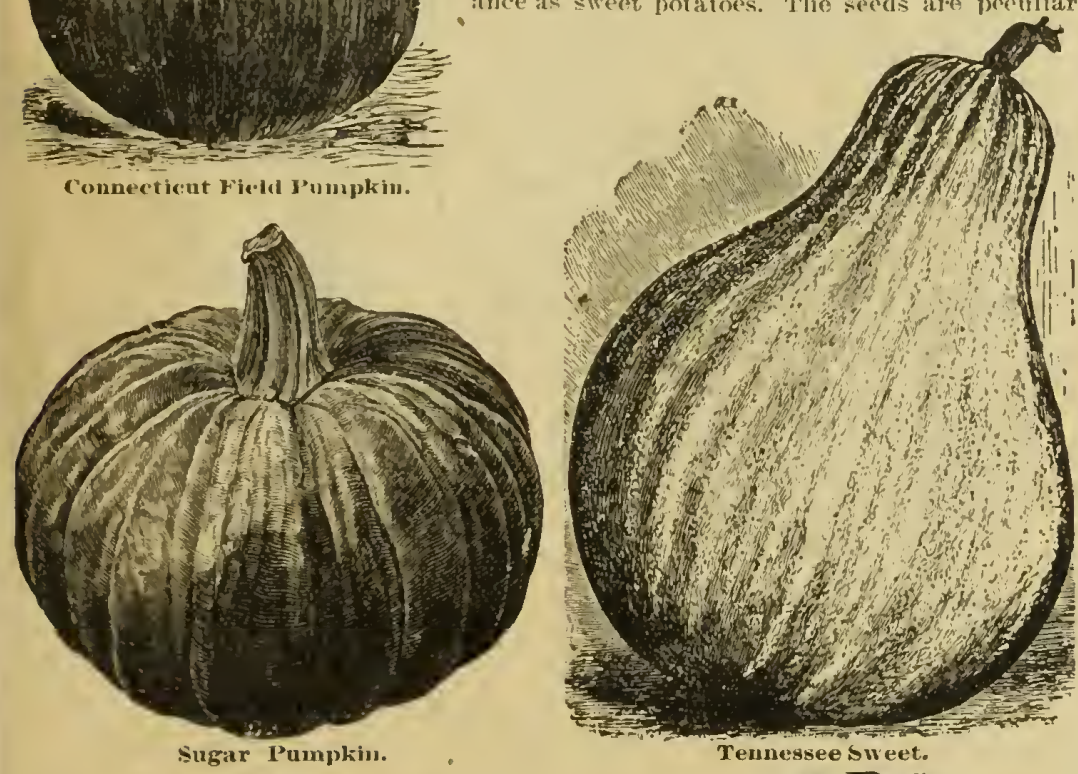

MAMMOTHREDETAMPES. skinsmooth

bright glosiy rea. Hesh deep orange, vory thin avd

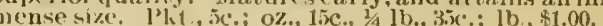

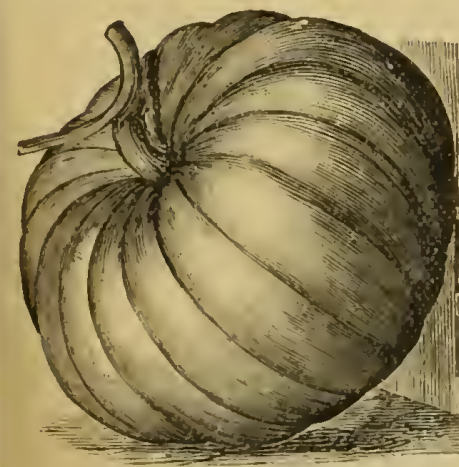

Largo ('lueene J'ungkiu.

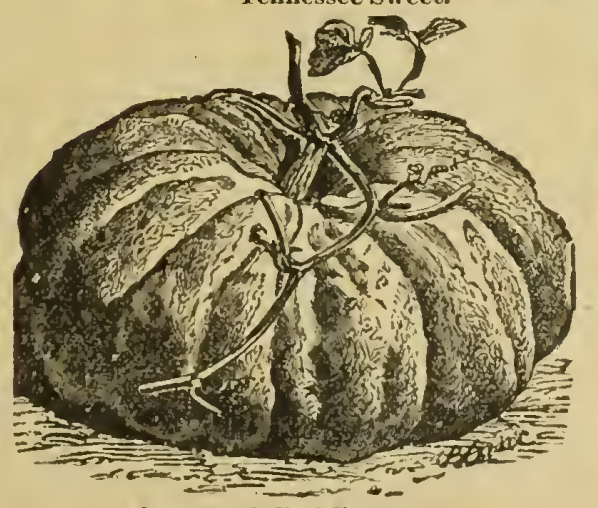

Iammoth Led Hitumpes.

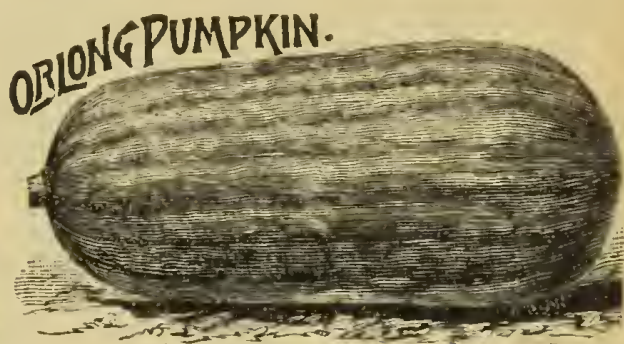

Golden Oblong l'umpkin.

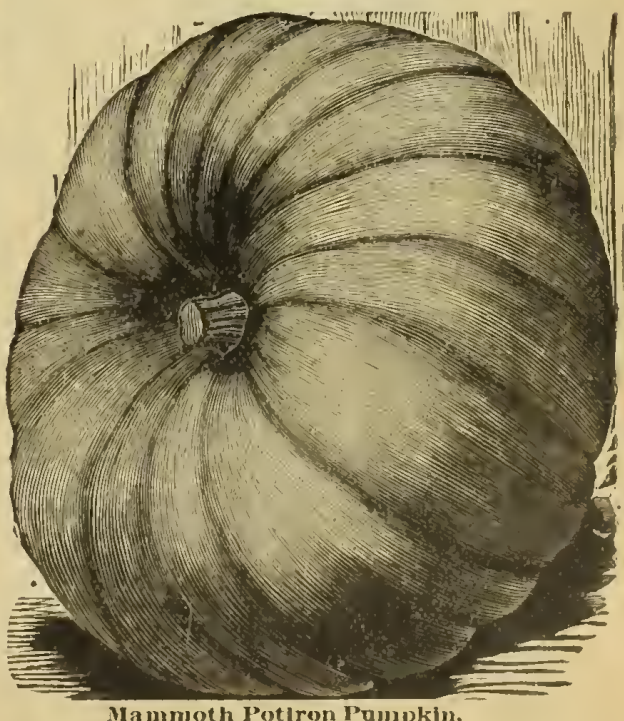

CALHOUN. Wherever heard trom, this varlety gives the highest satisfaction, every one speaking of its sisperior quality. The ontside

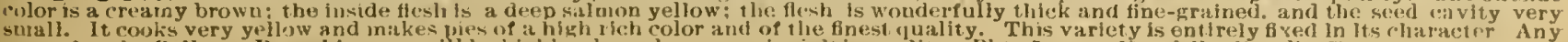

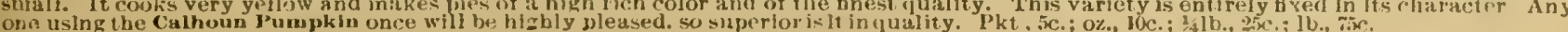



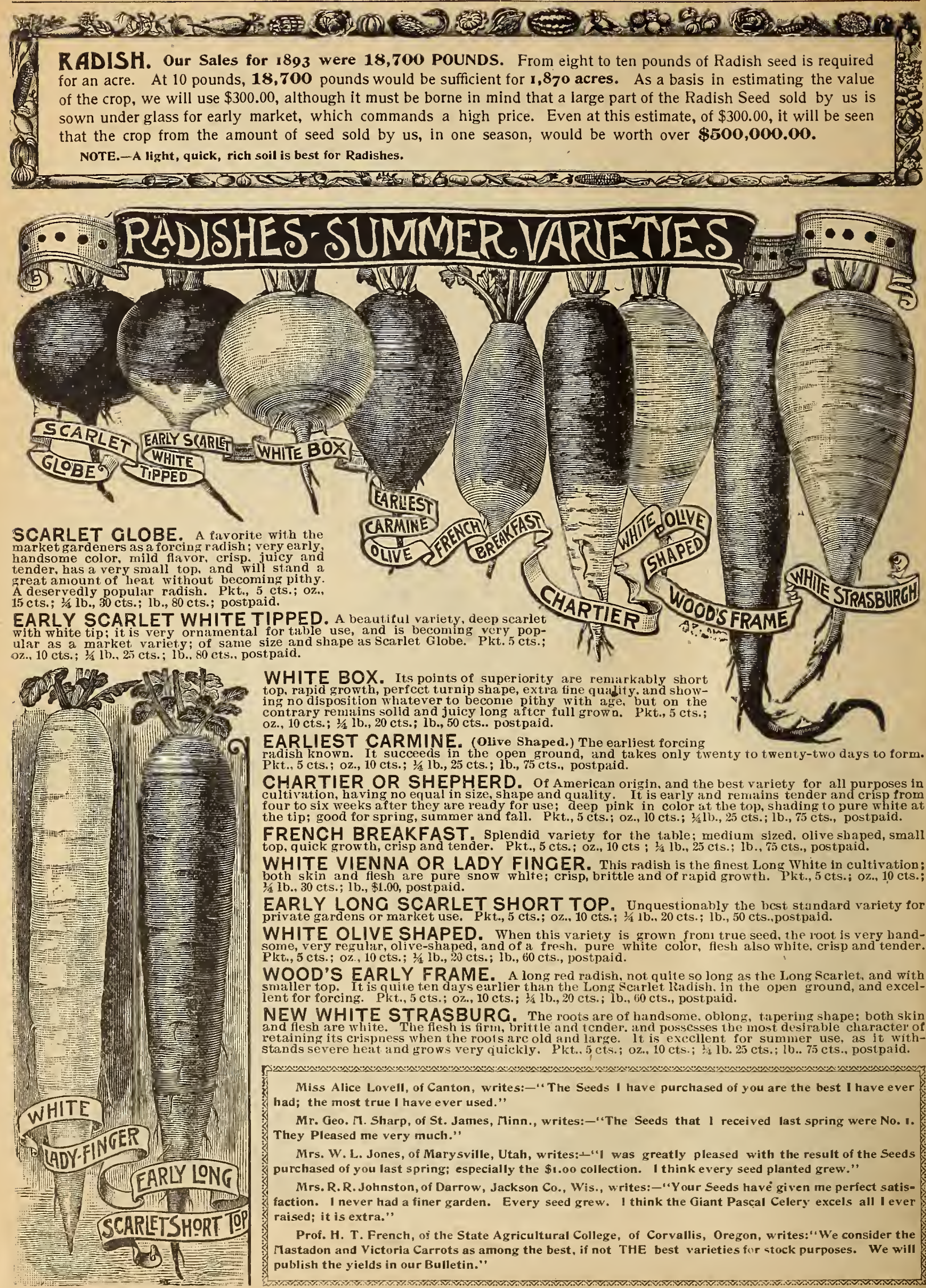

SCARLET GLOBE. A lavorite with the marketgardeners as a lorcing radish; very early, tender, has a very small top, and will stand a great anount of leat without becoming pithy. $15 \mathrm{cts}$; ; $1 / 4 \mathrm{lb}$ 30 cts.; lb., $80 \mathrm{cts}$.; postpaid.

EARLY SCARLET WHITE TIPPED. A beautiful variety, deep scarlet

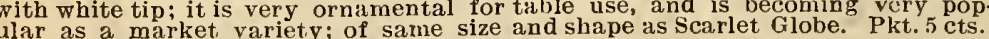

WHITE BOX. Its points of superiority are remarkably short top, rapid growth, perfcct turnip shape, extra fine quillity. and showcontrary remiains solid and juicy long aftcr full grown. Pkt., 5 cts. oz., 10 cts.; $1 / 1$ lb., 20 cts.; lb., 50 cts.. post paid.

EARLIEST CARMINE. (Olive Shaped.) The earliest forcing

radish known. It succeeds in the open ground, and takes only twenty to twenty-two days to form. CHARTIER OR SHEPHERD. Of American origin, and the best variety for all purposes in cultivation, having no equal in size, shape and quality. It is early and remains tender and crisp from our to six weeks after they are ready for use; deep pink in color at the top, shading to pure white at FRENCH BREAKFAST. Splendid variety for the table; medium sized, olive shaped, small top, quick growth, crisp and tender. Pkt., 5 cts.; oz., 10 cts ; 1/4 1 b., 25 cts.; lb., 75 cts., postpaid.

WHITE VIENNA OR LADY FINGER. This radish is the finest Long White in cultivation; both skin and flesh are pure snow whlte; crisp, brittle and of rapid growth. Pkt., 5 cts.; oz., 10 cts.;

EARLY LONG SCARLET SHORT TOP. Unquestionably the best standard variety for

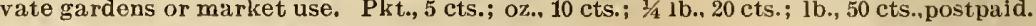

WHITE OLIVE SHAPED. When this variety is grown front true seed, the root is very handPkt., 5 cts.; oz., 10 cts.; 14 lb., 20 cts.; lb., 60 cts., postpaid.

WOOD'S EARLY FRAME. A long red radish, not quite so long as the Long scarlet, and with maller top. It is quite ten days earlier than the Long scarlet kadish. in the open ground, and excel-
ent for forcing. Pkt., $5 \mathrm{cts}$.; 0 z., $10 \mathrm{cts}$; $1 / 1 \mathrm{~b}$., $20 \mathrm{cts}$; ; lb., $60 \mathrm{cts}$., postpaid. NEW WHITE STRASBURG. The roots are of handsome, oblong, tapering shape; both skin

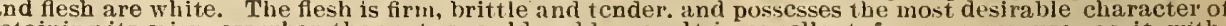

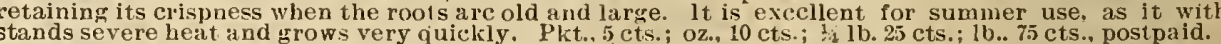

Miss Alice Lovell, of Canton, writes:-" The Seeds I have purchased of you are the best I have ever
had; the most true 1 have ever used."
Mr. Geo. M. Sharp, of St. James, Minn., writes:-“"The Seeds that I received last spring were No. I.
They Pleased me very much."
Mrs. W. L. Jones, of Marysville, Utah, writes:-“I was greatly pleased with the result of the Seeds
purchased of you last spring; especially the $\$ 1.00$ collection. I think every seed planted grew."
Mrs. R. R. Johnston, of Darrow, Jackson Co., Wis., writes:- "Your Seeds have given me perfect satis-
faction. I never had a finer garden. Every seed grew. I think the Giant Pascal Celery excels all I ever
raised; it is extra."
Prof. H. T. French, of the State Agricultural College, of Corvallis, Oregon, writes: "We consider the
Mastadon and Victoria Carrots as among the best, if not THE best varieties for atock purposes. We will
publish the yields in our Bulletin." 


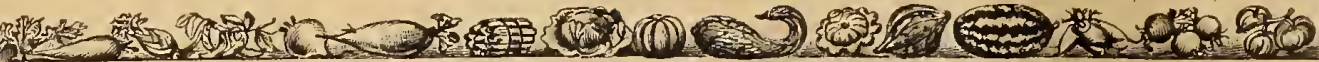

SQUASH. Our Sales for 1893 were 3,700 POUNDS. Like Pumpkins, this is a difficult crop to estimate,

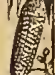
although its value is by no means uncertain. A well known writer on vegretables, says of them: "A class of vegetables

3

We are glad to call to the attention of our customers, a new squash, THE FAXON,
striking merits (see description and cut) and which bids tair to become a most popular sort. embracing more marked distinctions in sorts, fitted for more varied uses and to be found, during the extremes of the seasons, in a better state of perfection, than perhaps any other product of our gardens."

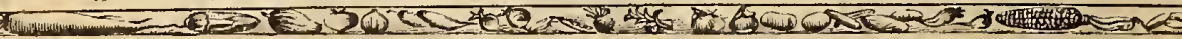

उद्य
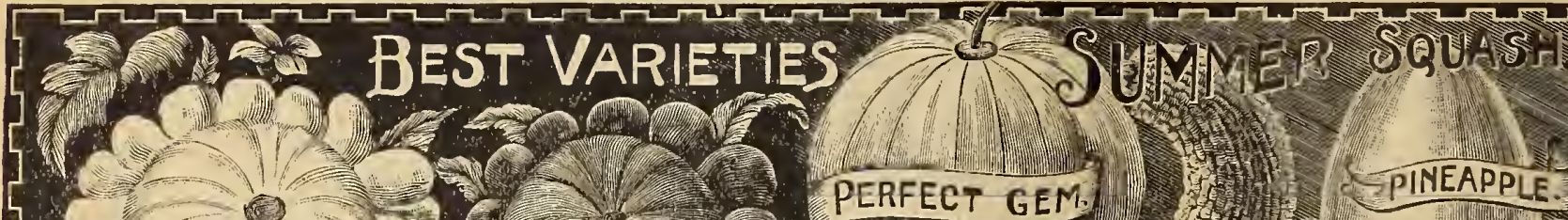

(a)

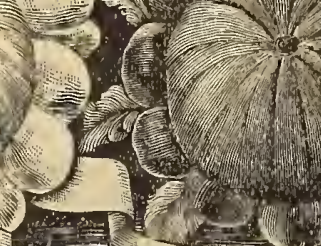

PERFECT GEM.

11) SPINEAPPLE

1. WHHITE BUSH.

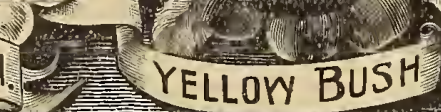

SUMMER SQUASHES.

WHITE BUSH SCALLOPED.

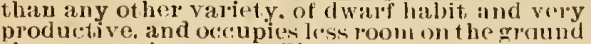
this any oriher wort. Pkt.. . ct.

YELLOW BUSH SCALLOPPED yerion

PERFECT GEM.

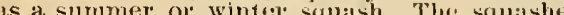

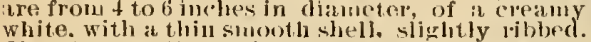
SUMMER CROOKNECK.

PINEAP cts.., posipaiti.

and fatl use, ifie flesh is thick boum white

WINTER SQUASHES.

HUBBARD, (N. 13. G. Co.'s selected Stork.) The eontinu(d popularity of the Hubbard has led us to pay particialar attention to our

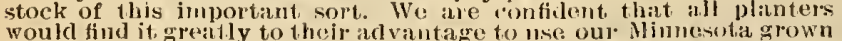
seed. and by so doing not
earliness in mat a rity.

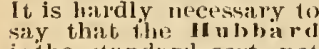
is ihe stiandiard sort, not
only as a lout keper. but on aceount of its quility,
which is unsururpissed. Pki

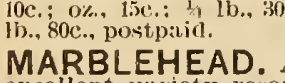
excellent valrety resem-
bling the Ilubbard. The flesh is riatlele lighter in

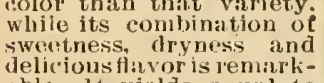

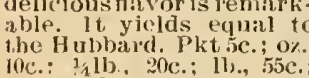
postpaid.

EARLY ORANGE MARROW Bosion Man'ow, but has and much more produc deep orituge. Iniking the
squash of very hind thone

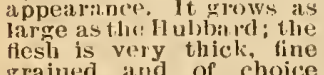
grained ind of choice
quality. The squaslies are
in prime condition from September to Januiary. jb.. inc., post pa

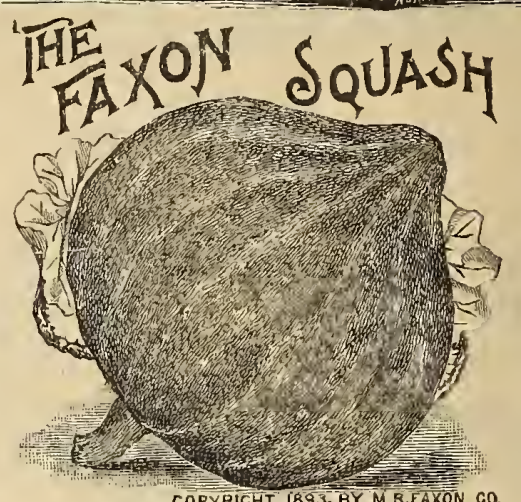

WINTER SQUASHES.

THE FAXON. (New) The in troducer is a deep orange yellow, cavity very small and seeds few; the special peeuliarity, however, is like any squash, when cooked there is practically none, the sbell or inedible pirt being only about as thick as a sheet of writing paper. It is the and for squash pies, it must be tried to be appreciated. We know a trial will convince all of its asa snmmer soluas. It is the best winter variety we know of, being a, very late kecper, we have condition in A pril and llay. It is the only squash that we ever saw that every specimen is of superiol quality without reg ax d 20 size or whether

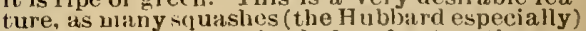
must be thoroumbly ripe before frost, or the crop CORYRICHT. I893. BY M. B.FAKON CO. is lost. 1t, is not so with "The Faxon squash: prery specimen can be gathered and used. productive, of niedium size that this new viliety is destined to becone a stiandar mon: squashes, both for home use and marhet purposes. hesquash specialist. writes us: "I have no personal interest in this new squash whatever, but l earnestly advise you to catalogue it. Your cimatoners will ili thank you for it."

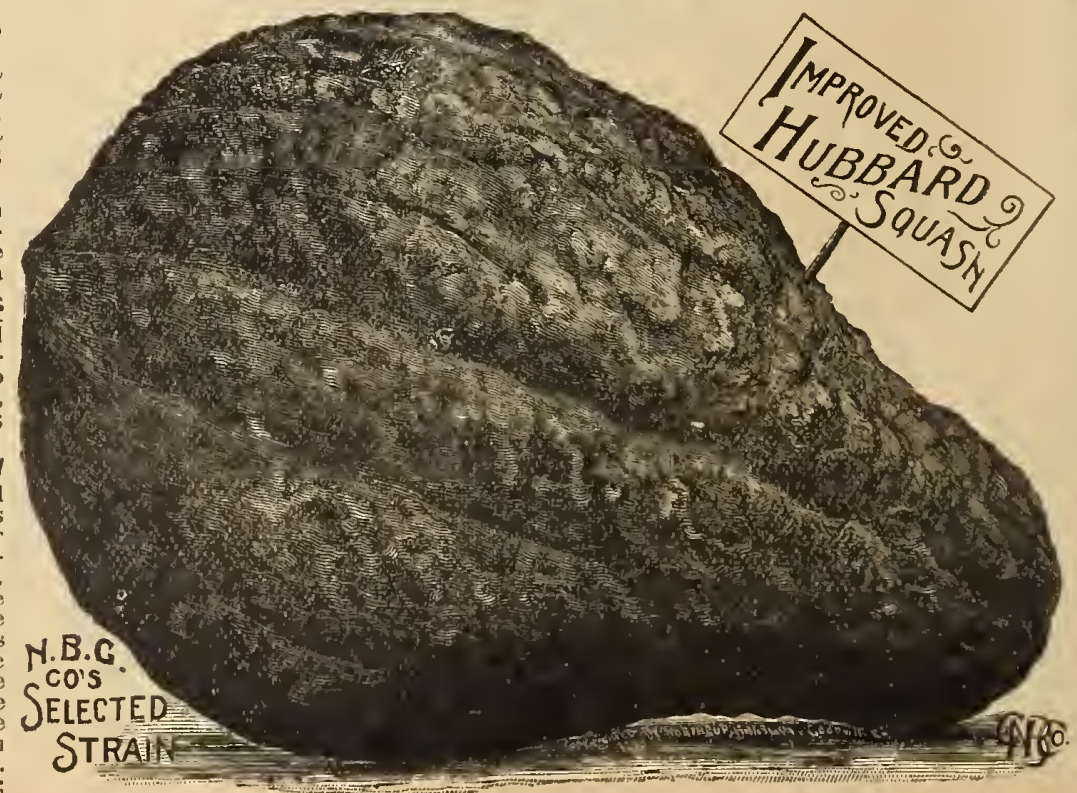
2.ic.: 10 pkts., 81 ; oz..,

ESSEX HYBRID. A very productive squash of the finest quality, and inens lining been kep until tune is sound an good as when gathered. It is of early, quick growth. sucesesfully as a secon crop, following early potators. peas. etc. Pkin, $5 \mathrm{c}$ postipaid.

MAMMOTH CHILI Giow: to enorlous size. having attained th and ninety-two pounds. They are niost profitabit to grow for stock feeding. particularly when roo grown. 'The outer color is a rich orange yellow, the skin is quite smooth, witls side fissures; flesh is very thick, and is rich, yellow cliur huaitity only mo It is the "I umbo" of the squash fizmily. Pkt., 10c.

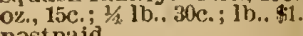
postpaid. 
DWARFCIHAMPION ENA TOMATO

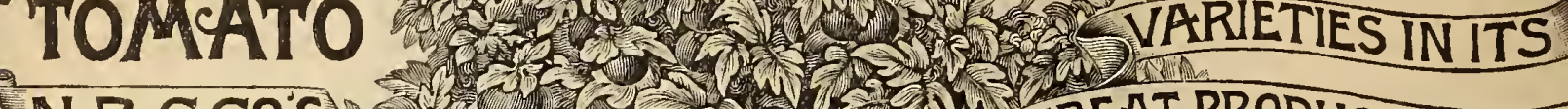
(N.B.G.COS 2 S SELECTED STOCK

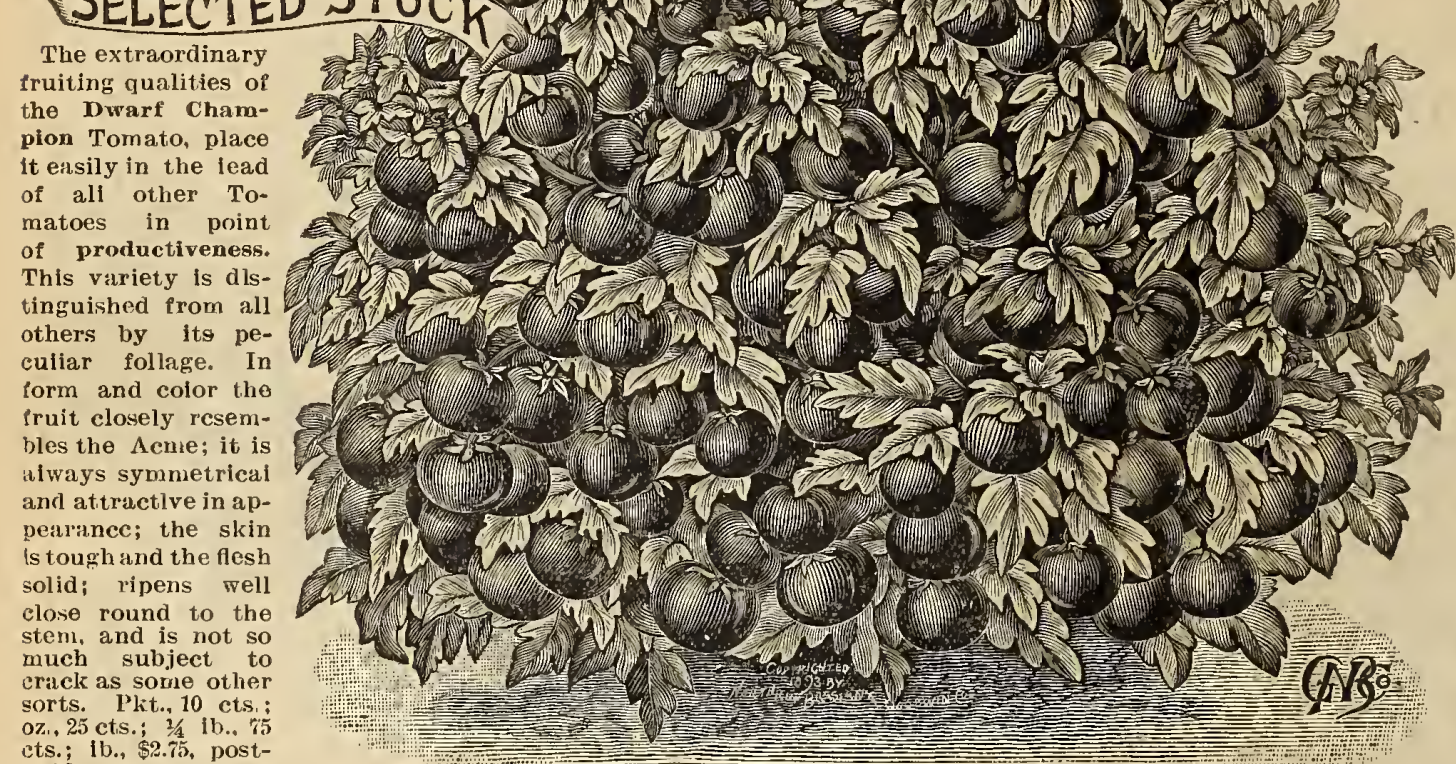

Leroy N. Brown \& Son, Ohio, growers of Tomatoes, Celery etc., writes: "The seed of New Dwarf Champion you sent us is a daisy, a dandy, the most perfect type of Dwarf Champion we have ever grown. It has been pronounced by many growers who have seen the plants, the prettiest they have ever seen."

STRAWBERRY OR WINTER CHERRY TOMATO.

This, unlike other varietics, grows in a husk or pod, and may be kept
ail winter if the husks are not removed, the fruit has a pleasant strawberry-like flavor, and is much relished raw, but is generally most any dry soll, are easier rais
bearers. Plkt., $10 \mathrm{cts}$; postpaid

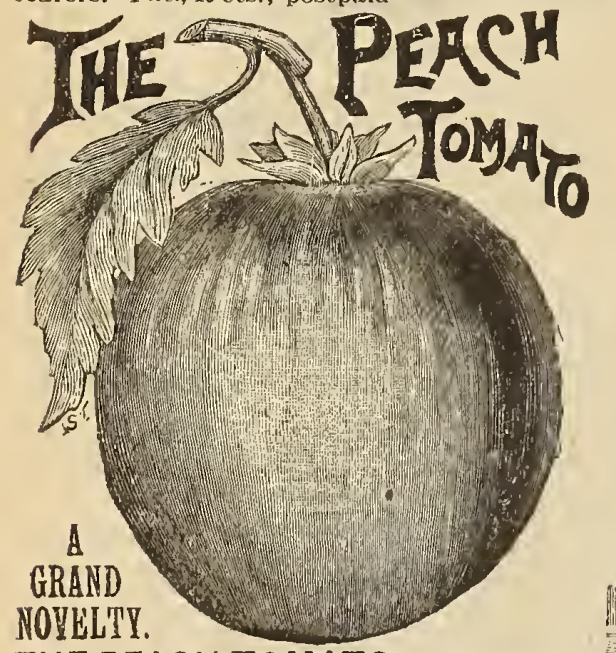

THE PEACH TOMATO. The fruit re-

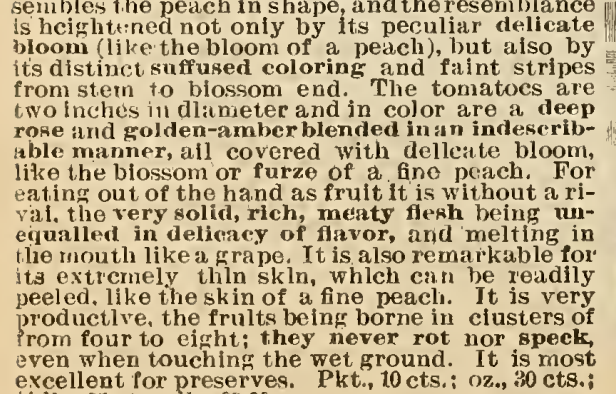
ib., 85 cts.; 1 b., 93,00
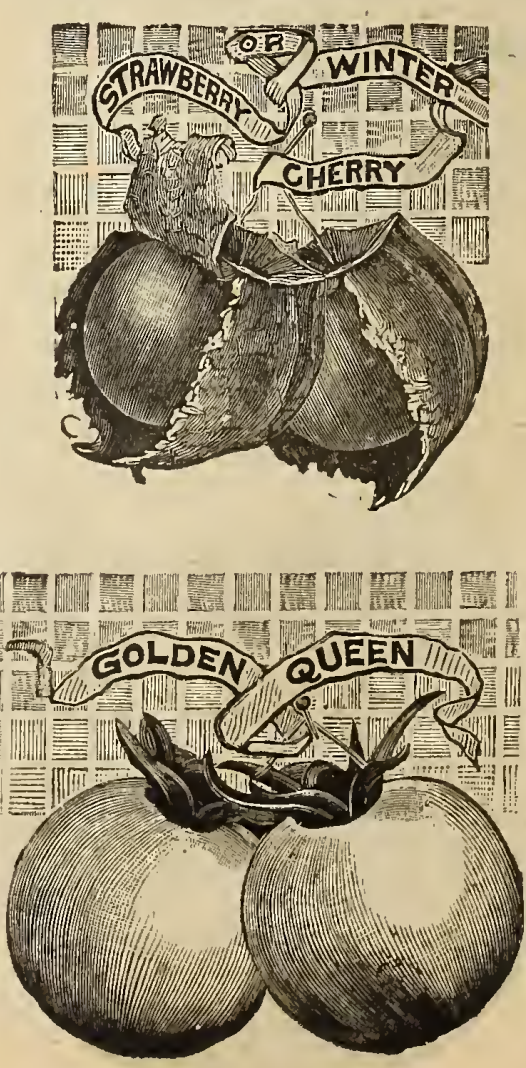

GOLDEN QUEEN TOMATO. The superlor flavor of the yellow varieties is bringing them into fitvor as table fruit, and those who think of a yellow tomato as the rough fruit of the old yellow smooth as the best of the red varieties, and of a fine and distinct flavor. Pkt., 5 cts.; oz., 25 cts., postpaid.

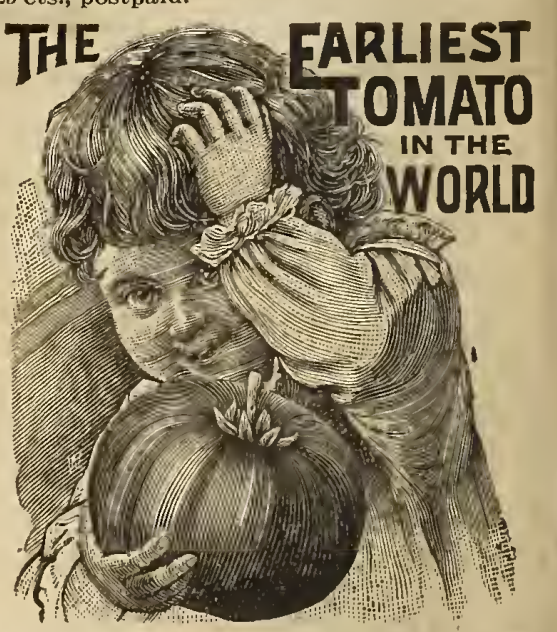

ELECTRIC. The earliest romato. We introduced this Tomato some year's ago, but from being somewhat ridged, we ceased offering it however, from those who are wliling to overcount of its extreme earliness, that we have deeclded to again cutalogue it, believing that in so dolng we will not only please many old cus-
tomers, but new ones as well. Pki.. 5 c1s.; n...

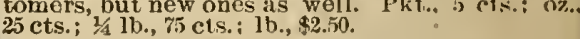
E. A. Rhinehart, Bird City, Kansas, writes: I have had your seeds for two years and like them very much. 
TREE TOMATO. Thls tomato has been before the public for some years, but stlll may be called a novelty, as its appearance is so dis. tinguished as to excite expressions of surprlse, no ulatter how frequently seen. Its chlef characteristic, is its wonderful productiveutsis, although in eating qualities it is first-class. Large, and of it peculiar bright red color. pkot as smooth, perhaps. . .

HERBS - POT, SWEET AND MEDICINAL. Save a corner for a few Pot and Swect Herbs (for flavoring sonps, meats, etc.): indlspensible to every garden, whlle Mediclnal Horbs will be found useful. Thrive nicely MARJORAM, Sweet. The leaves and ends of the shoots are highly

PENNYKOYAL. Agreable odor and flavor. Plit., 10c.; 3 pkts., 25c. DILL. The seeds have an a ronatic odor and pungent taste. They SAGE. Mlost used herb for seasonin. l'kt., 5c.; oz., 15c.;

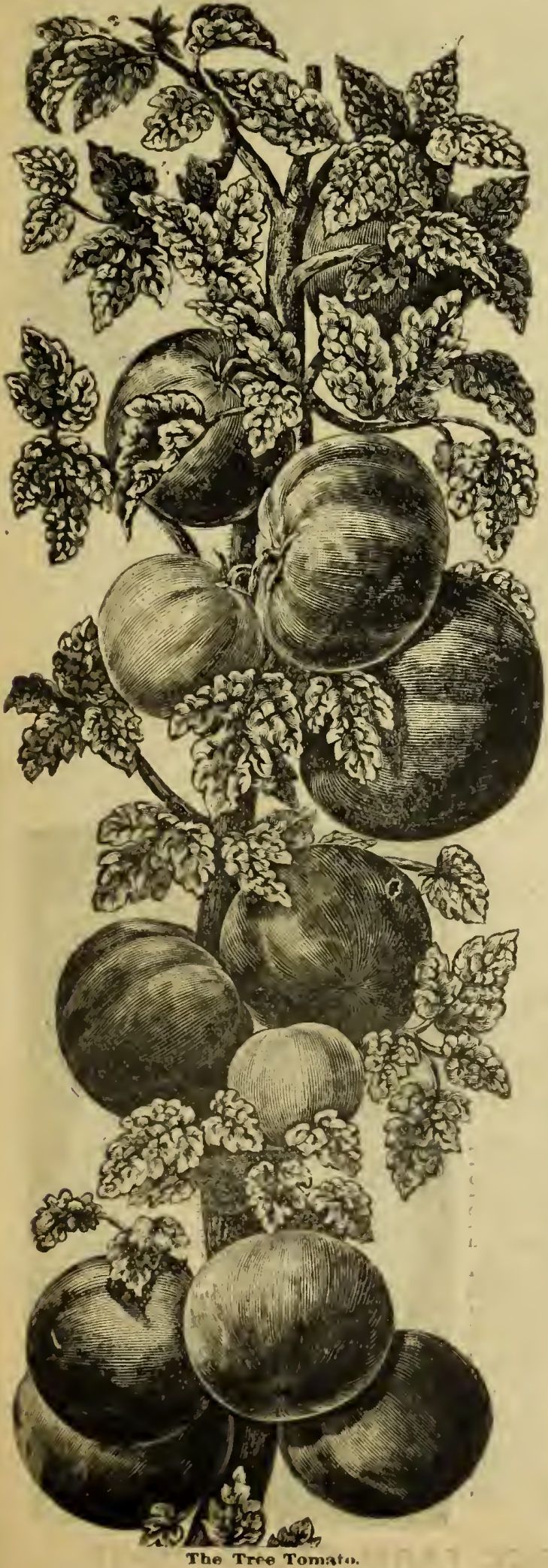

Busic, Sweet. The leaves

SAMENDER. An ar

Axisis

BORAdw. Leaves used for flavorinu and finwers furnish bee pusture

CORIANDER.

ENNEI, SW Q⿱⺈

TOBACCO. $\begin{aligned} & \text { Oar TOBACCOS are from the celebrated RAGLAND } \\ & \text { TOBACCOFARM, and sur patrons may be assured of }\end{aligned}$

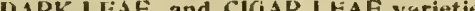
作 ERN or NORTHWESTERN St, tes, please note remarks about the fir:STCR it is

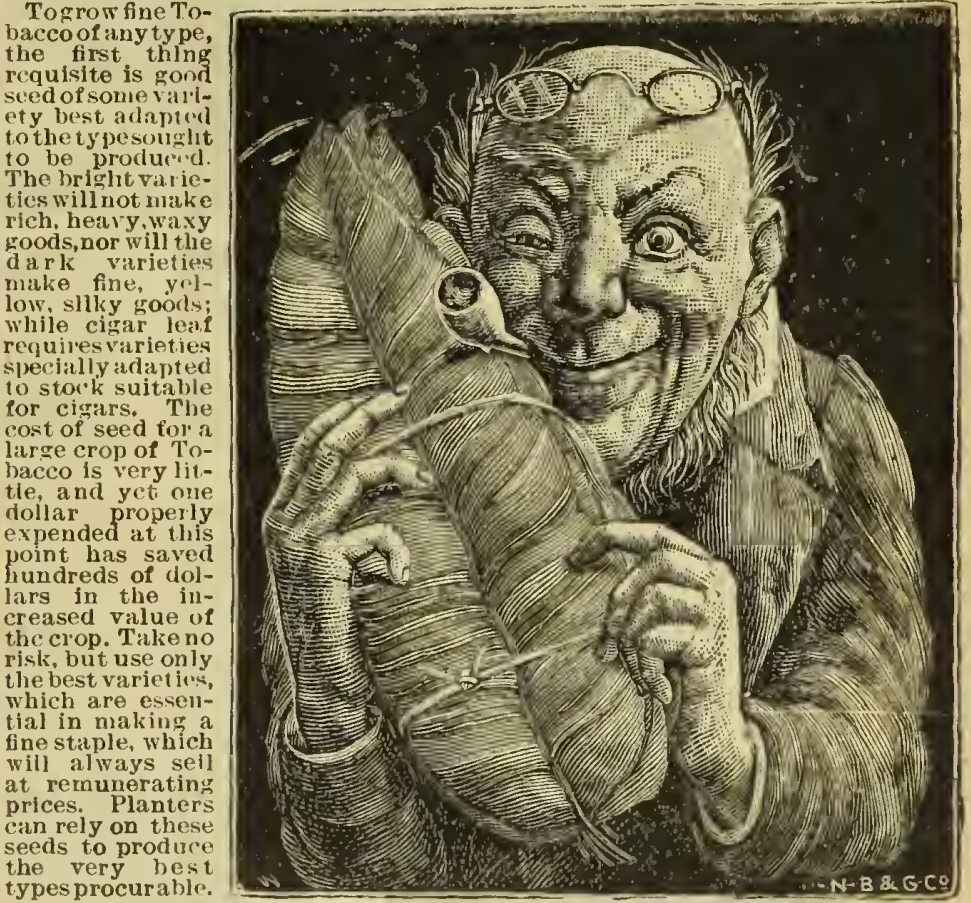

BRIGHT YELLOW LEAF VARIETIES.

HESTER.

BRIGHT YELLOW LEAF VARIETIES.

for their section, that we were fed the past

tion as to the
in this cone
a large num

hese varieties: "The

Trom

tly in the

(

RAGLAND'S CONQUEROR

CLIMAX.

\section{DARK LEAF VARIETIES.}

YELLOW MAMMOTH. A new Western varlety of the Export type TENNESSEE. Excellent for dark strips and wrappers. Pkt., 5 ets. : oz.,

\section{CIGAR LEAF VARIETIES.}

CONNECTICUT SEED LEAF. The largest. finest and best virlety PENNSYLVANIA SEED LEAF. The best grown in the famous BIG HAVANA. A hybrid Havana or Cuban Sead Lear. A l, per; delightful fiavor; very early. This ls the best 
TURNIPS.-TABLE SORTS. ( (see Farm Seeds, , Fage 4i. )

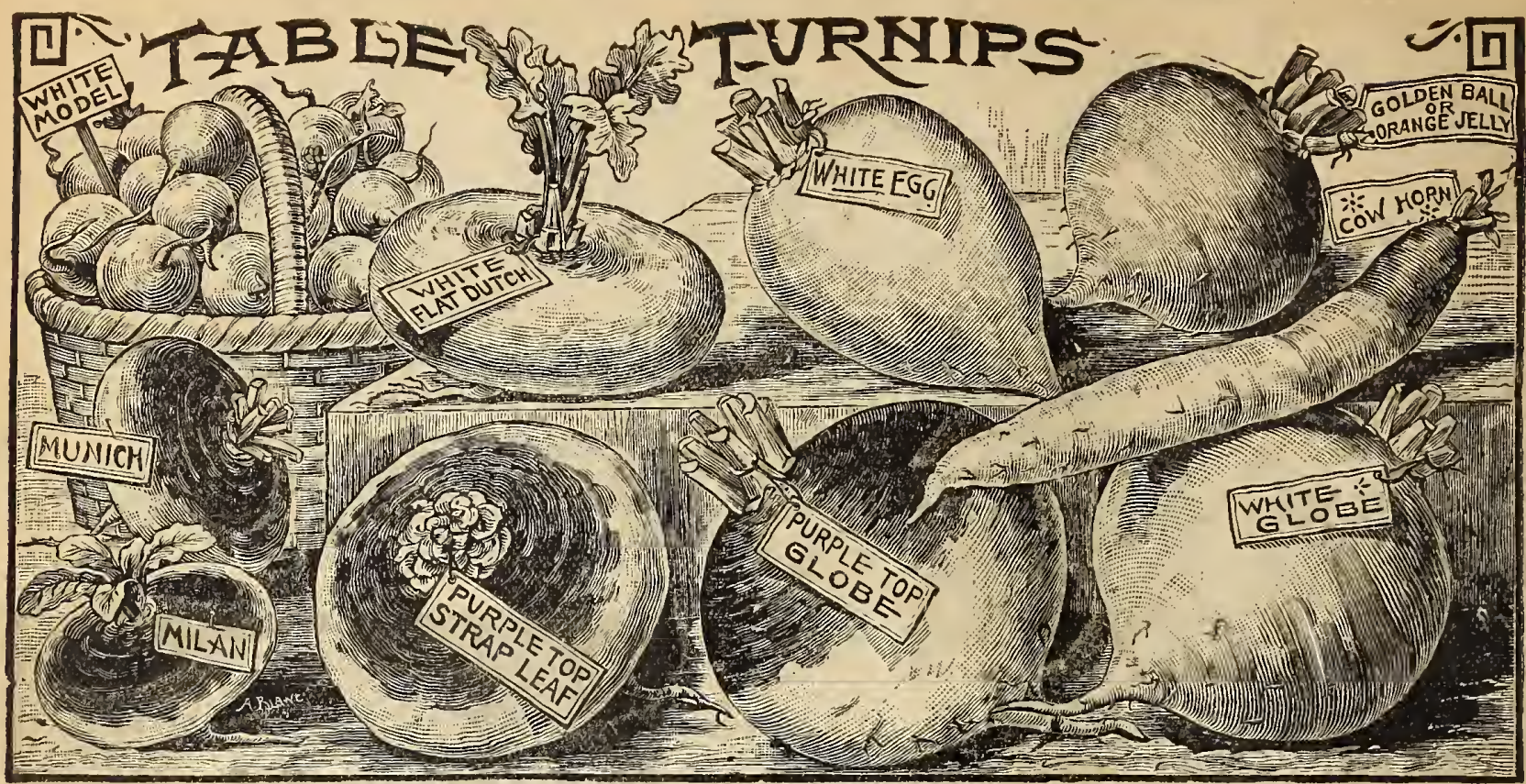

EXTRA EARLY PURPLE TOP MILAN TURNIP. The carliest variety. The tops are very small, distinctly strapwhite, with clear purple top. The nost desirable sort for forcing.

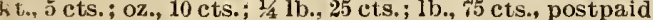

EARLY WHITE MODEL TURNIP. This is one of the ams beautirul ntte turnips possible to obtain. It is a clear pure talyle. It is not as good a keeper, however. as some of the other sorts.

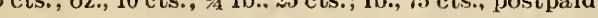

WHITE NORFOLK TURNIP. Our trial grounds afford u app'tunity of thoroughly testing the merits of different vegetafolk his the are not awites hat it is catalogued by any seedsmen in America. In Europe, at justly remains one of the most favorite sorts. It is white, of good favor it, is unequaled. On this account and its long keeping qualities, we strongly recommend it not only for family use, but for sale. want as mitny of our customers as possible to try this splendid turnip. Pkt., 5 cts.; oz., 10 cts.; 1/4 1b., 20 cts.; $1 \mathrm{~b}$., 50 cts., postpald.
EARLY PURPLE TOP MUNICH TURNIP. A very handsone early turnip. forming bulbs six inches in diameter within three months, It is one of the best for first crop, but after attaining for winter use. Pkt.. 5 cts.; oz., 10 cts.; $1 / 1$ lb., 15 cts.; lb., 50 cts.. GOLDEN BALL OR ORANGE JELLY TURNIP. One of the most delicious and sweetest yellow-fleshed Turnips. Not

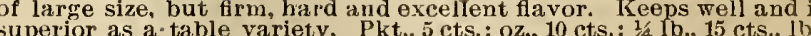
50 cts., postpaid.

PURPLE-TOP WHITE GLOBE TURNIP. of a per lect globe shape, about six inches in diameter, with smooth whit cts.; oz., 10 cts.; $1 / 4$ lb., 15 cts.; 1 b., 50 cts., postpaid.

Early Red or Purple Top Strap-Leaved Turnip. a general favorit with all, and more largely grown than any other turnip; will do wel to sow either broadcast or in drills, and will form good sized bulb in seven or eig

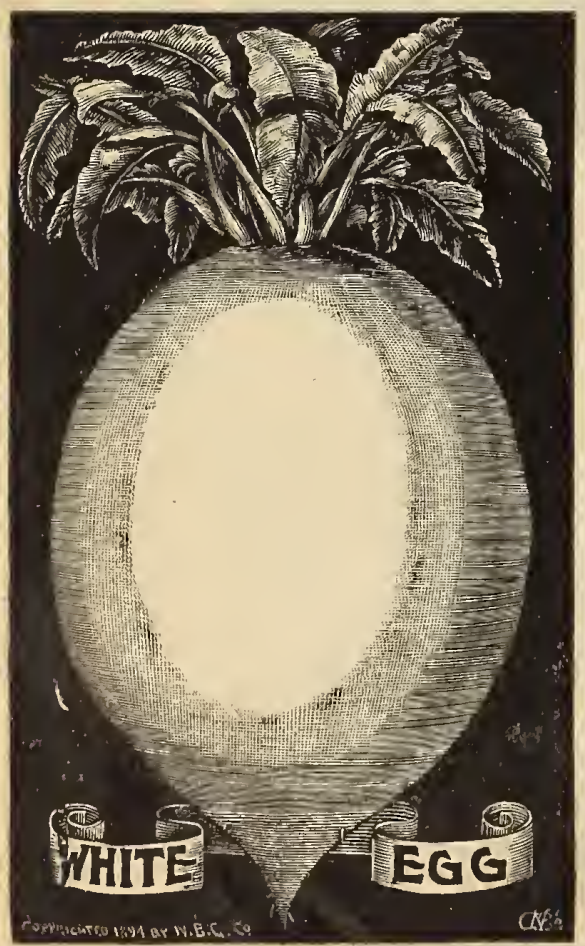

Early White Flat Dutch Turnlp, A very popular sort for either table use or for market; grows quickly, comes early; flavor and excellent quallty; produces 年 Pkt., 5 cts.; oz., 10 cts.; $3 / 4$ lb., 15 cts.; $1 \mathrm{~b}$. Cow-Horn, or Long White Turnip. This variety iscar Wlike Turnip. The variety is carrot like in form, growgenerally slightly crooked. It is pure White except a little shade of green at
the top. It isdelicate and well favored. the top. It is delicate and well tavored. 50 cts., postpaid.

White Egg Turnip. We have called especlal attention to this Turnlp by giving lt a double lllustration. Owing to the great popularity that thls little turalp has attained, the purchase of the able risk as poor stocks have been abundant and pure seed scarce. Our seed has been grown wlth great pains, and we believe it will satisfy the White Egg is one of the best for a prlvate garden and meets with a ready sale ln all large markets. It is not quite As handsome or as snlooth as the Nev Model, but it holds its quality better. In our estimation it falls littie short of the White Norfolk in quallty, but 1t is earlier than the Norfolk and is better known in the leading markets. All in all, it is one of the most useful Turnlps $20 \mathrm{cts}$; $1 \mathrm{~b}$., $50 \mathrm{cts}$., postpald.

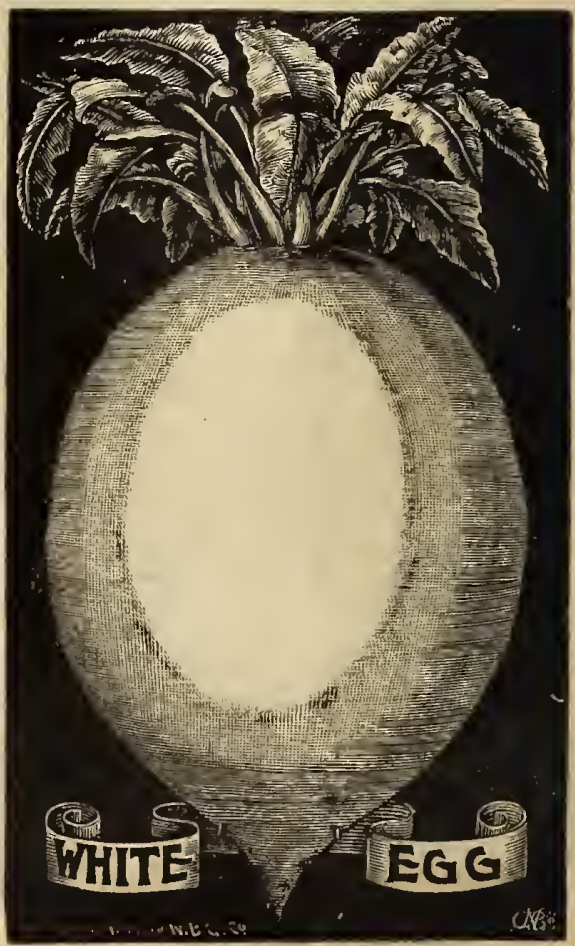

FOR STOCK TURNIPS, (RUTA BAGAS) SEE FARM SEEDS, PAGE 47. 
Y OUR VEGET ABLE SEED COLLECTIONS (For Flower Seed Collections see Page 75) have become such a teature of our Annual Catalogue, and have proven so popular with our customers, that we are glad to again give them the usual space, especially as they have been the menis of introducing our seeds to many who might
not otherwise have tried them. Tlıe expression of Mr. Lowell, Canton, S. D., who writes: "I never received so much satisfaction from One Dollar's worth of seeds in all my farming experience," is an illustration of the many gratifying reports we have received to the same effect. Our collections are made up from the best varieties.

\section{OVR ${ }^{\text {}}$ IOO COLLECTION OO 30 BEST VEGETABLES}

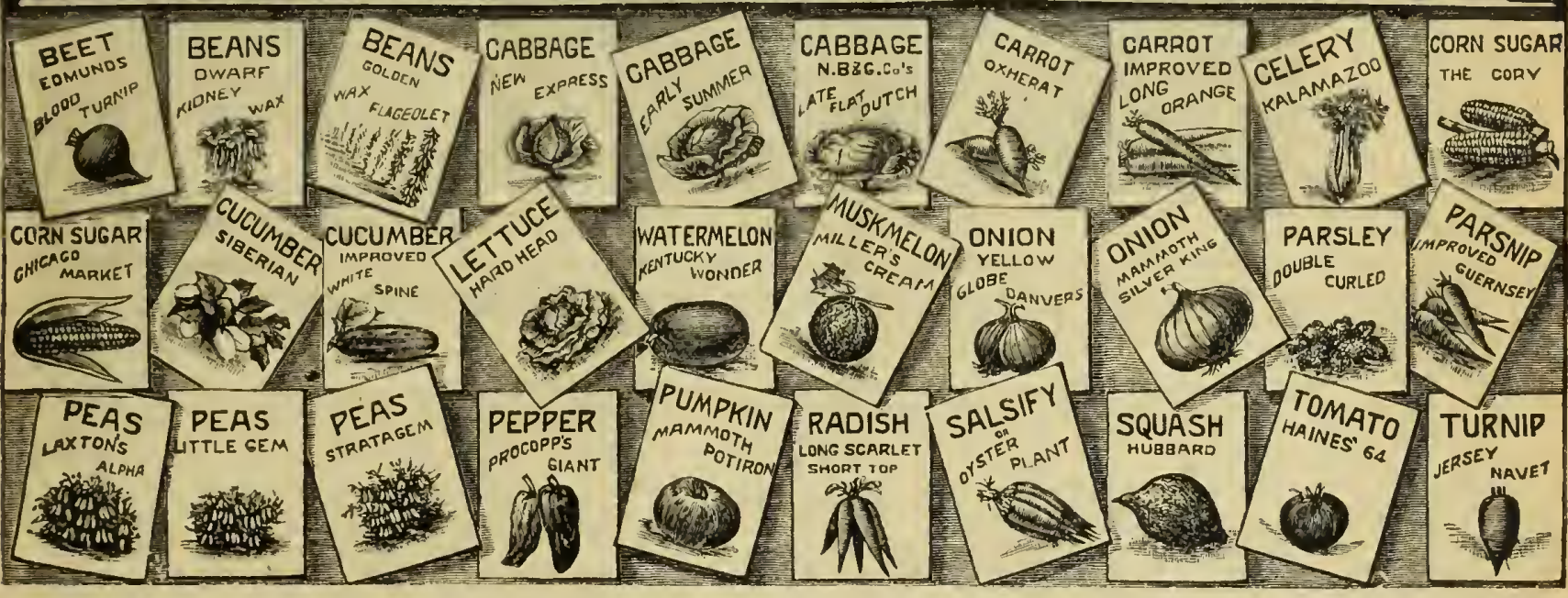

\$2.00 WORTH OF SEEDS AT CATALOGUE PRICES FOR \$1.00.

For $\$ 1.00$ we will send, postpaid to any address, one full size packet each of the 30 choice vegetables above illustrated, sufficient to make a complete kitchen garden for a small family. We make this liberal offer particularly with a view of introducing our seeds to those who have not been in the habit of using them. Six Bollections, \$5.00.

\section{OUR \$2.00 COLLECTION OF BEST VEGETABLES. Many purchasers find the work of making up} Def time or want of knowledge as to which are the best sorts for a family garden. To such, our \$2.00 Collection will prove a great convenience. It is just such an assortment as should be planted in a kitchen garden, and farmers especially will find it well suited to their wants. Please note, also, that the same varieties and quantities, if selected from this catalogue at our regular prices, would cost over $\$ 3.00$.

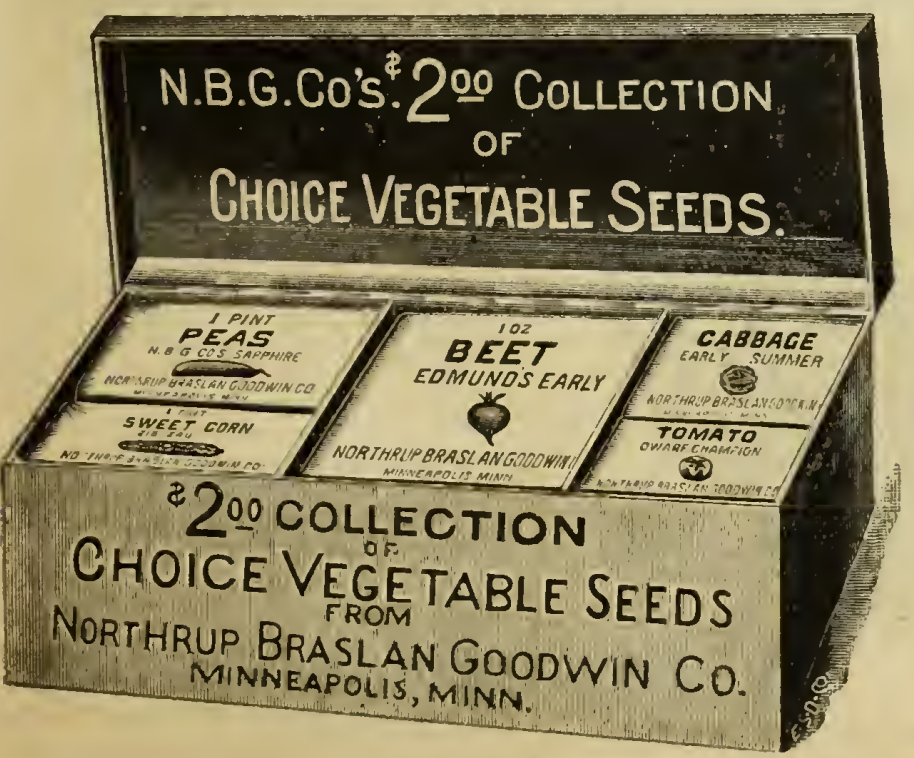

CONTENTS OF OUR $\$ 2.00$ COLLECTION

Which wlll be sent, postpaid, to any address for $\$ 2.00$ or by

express, at purchiserers expense, tor $\$ 1.75$.

1. pikt. Beans, Scarlet Runner. 15 cts.

1 oz. Beet. Ed luundel's Turnip. Blood, -

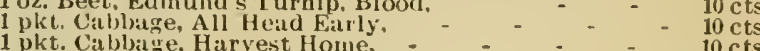

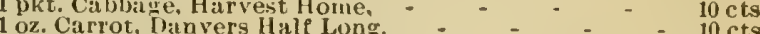

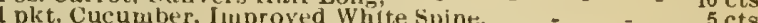

1/2 pint Corn, Portland Furly, -

10 pint Corn, yone such, - - $10 \mathrm{cts}$

1 pkt. Let tuce, White St:ir, - - - - $5 \mathrm{cts}$

1 pkt. Lettuce, Hanson llead, - - - - $5 \mathrm{cts}$

1 plit. Witter Melon. Kientucky Wonder, - - - $10 \mathrm{cts}$

1 oz. Onion, Yellow Globe D:
1 pkit. Parsley, Mloss Curled,

1 plnt

1 pint Pe:is. Teleplione,
1 plnt Pets. Chatuipion of

pkt. Pepper, Larye Bell or Bull

1 oz. Ritdish, Fitrly Seitrlet Turnip.

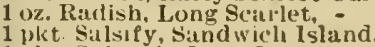

1 pkt. Spinach. Long Standing.

1 pht squash, The Fuxon.

1 pit. Tomato. Ruyal led,

1
1 pkt. Tomato, New Stone,
1 pkt. Tomato, New Peach,

1 pist. Turnlp. White Egg.

\section{0 cts.}



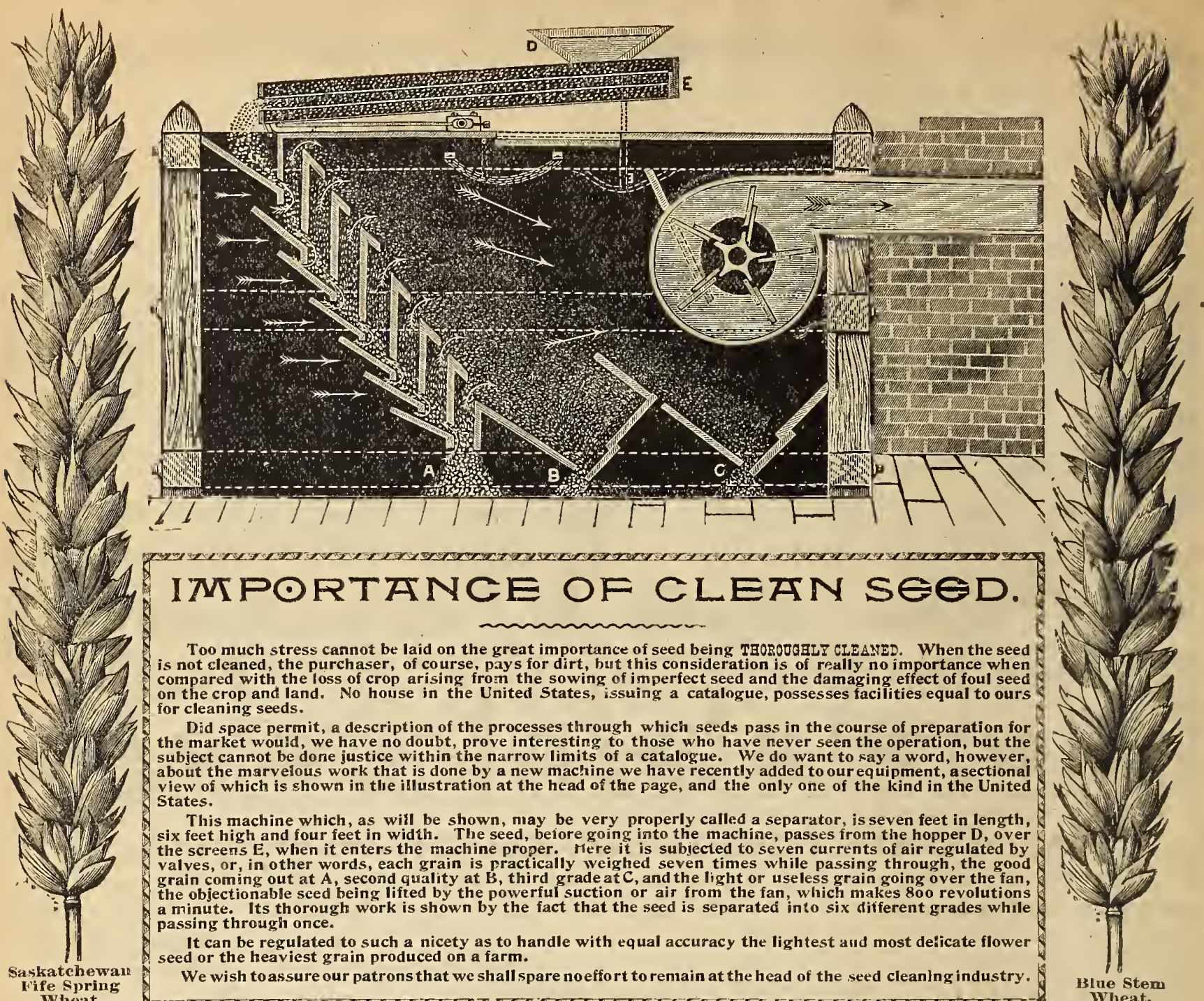

Too much stress cannot be laid on the great importance of seed being THOROJGHLY CLEARE. When the seed is not cleaned, the purchaser, of course, pays for dirt, but this consideration is of really no importance when compared with the loss of crop arising from the sowing of imperfect seed and the damaging effect of foul seed
on the crop and land. No house in the United States, issuing a catalogue, possesses facilities equal to ours for cleaning seeds.

Did space permit, a description of the processes through which seeds pass in the course of preparation for the market would, we have no doubt, prove interesting to those who have never seen the operation, but the subject cannot be done justice within the narrow limits of a catalogue. We do want to kay a word, however, view of which is shown in tlie illustration at the head of the page, and the only one of the kind in the United States.

This machine which, as will be shown, may be very properly called a separator, is seven feet in length, six feet high and four feet in width. The seed, before the screens $E$, when it enters the machine proper. Mere it is subjected to seven currents of air regulated by vain coming out at $A$ recond quality at $B$, third grade at $C$, and the light or useless rrain going over the fan, grain coming out at $A$, second quality at $\mathrm{B}$, thictul a minute. Its thorough work is shown by the fact that the seed is separated into six different grades while a minute. Its thoroug

It can be regulated to such a nicety as to handle with equal accuracy the lightest and most deticate flower Wed the heaviest grain produced on a farm.

We wish to assure our patrons that we shall spare noeffort to remain at the head of the seed cleanlng industry.

wife spring

VELVET CHAFF BLUE STEM SPRING WHEAT, A distinct varlety from all other sprling witehts, velvet-like surface, peculially distinct frons
other wheits. Also the stem, just below 1 he head, when green, has a beautiful blue bloon on it, just similar to the bloom on a gi"ape, and over the stem. This bloom disappear's as the wheat ripens, and the stem and straw ascume free from rust The kernel is of the hiard varfety, similar to Scotch Fife, more productive, one of the best spring wheats for nulling. Lhi peck, $50 .$. bush., $\$ 1.50 ; 2$ bush. 52.75 , bass included.

\section{SASKATCHEWAN FIFE SPRING WHEAT.}

Noted for its great productiveness, earliness. vigor and freedom from smut and all diseases. This whieat has beconie so well known as to render exiended deccription of it unnecessary. trade in $18 \times 4$, and it lias well sustained the claims then made for it, as the eirrliest and healthiest Spring Wheat. p1.5t; 2 bu., $\$ 2 . \tau 5$, bags lncluded.

\section{PILLSBURY SPRING WHEAT.}

A few year's ago, Mr. C. A. Plllstury of the Pllisburv-Washburn Flour Mills Co.. of Ninnelizlng the serlous injury that was being done to the grain and milling interests of the Northwest by the deterioratinn of whent throngh sinall quantitles of a wheat that had been especmers of Minnesota with a vlew lo restoring the Hard Fife to its old time purity.

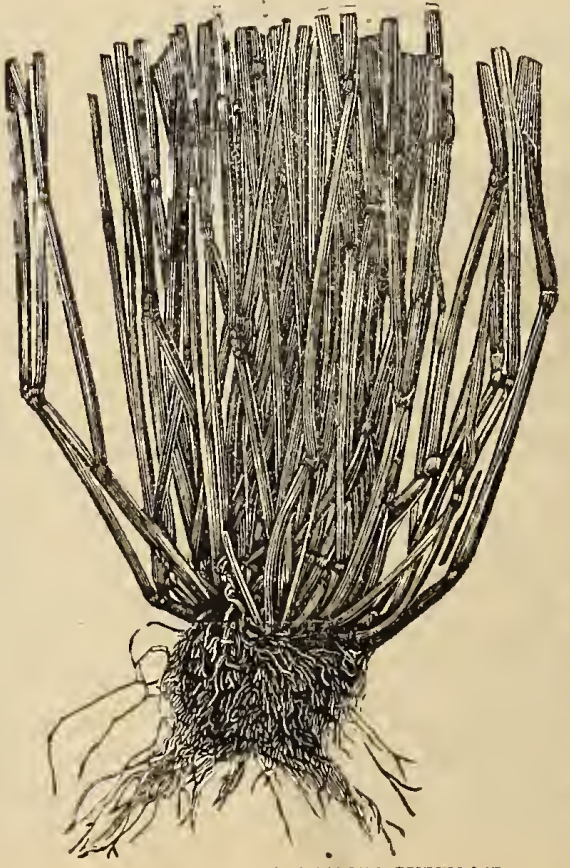

SASKATCHWWAN FIFE WHWAT. single Root.
Orue of these samples was recelved by a wellknown farmer in Clay County. Minnesota, who worked up the stock, and with whom we negotiated for the crop of 189\%. Ml r. Staliey, the Grower in the course of our correspondence with him stated: "Thls wheat was drilled ln Hay $4 \mathrm{th}$ and 7 th, and was cut A ugust 16 and $171 \mathrm{~h}$ I find it earlier than white Russian and Blue siem in adjoining flelds, and yieldlng rulu heiter than either, apparently one-third ing in on which thls whent was produced has been in wheat or oats very year since it was broken in 1882 , without «st. rotation, or manure. It lias ripenedmuch The evenly than either of the above naned The quautity we secured last year was not firce, and as we wished to reserve seed for planting this past spring. we ners unable to of ic and while the low prices of wheat at the of li and while the low prices of wheat at the prese wribt ailo we nif whenters to sow at least a sufficient yuanilty of this improved stock to be able the thing year to plant their own fields. with $\$ 1 . i_{i} ; 2$ bu., $\$ 3.25 ; 10$ bu., $\$ 14.00$, bags included.

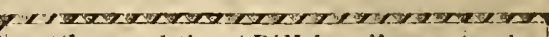

"I regard the "Pillsbury" as not only" the most froructive, but the best and purest Spring Wheat in existence." CHAS. A. PILLSBURY.

- Stephen Catt, of Deloraine, Manitoba, writes:-"Anybody that sends to you for seed has the best garden. I can justly say that they are just as you represent them to be every time." 


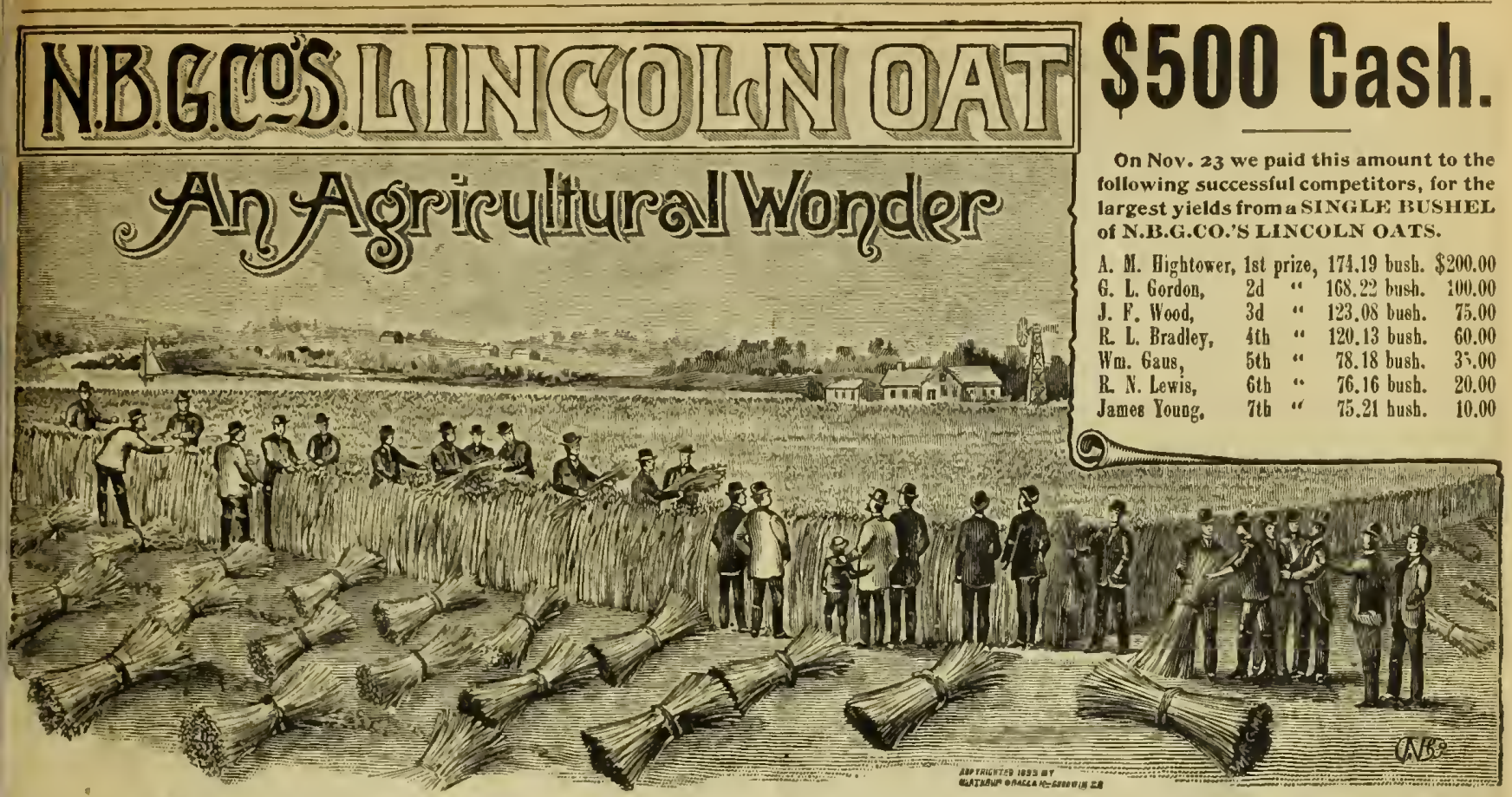

\section{N} or an average of over 116 bushels from each bushel sown, In introducing this Oat last year we made the following claims, and offered seven cash premiums amounting to $\$ \mathbf{5 0 0}$ for the largest yields from a single bushel of seed:

First-That the Lincoln Oat has produced one=third more than any other variety grown in the same localities. Second-It is very early. Third-It has thus far proven itself entirely rust=proof. Fourth-It stands up better than any other sort. 'Fifth-It is best for feeding on account of its thin hull, heavy meat and soft nib. Sixth-It is best for oatmeal or grinding for the same reasons.

How well our claims were substantiated is shown by the many flattering expressions received from those who bought the seed. Perhaps the strongest testimony lies in the fact that out of the many who grew them in all parts of the United States we have not received one unfavorable opinion or adverse criticism. The premiums were awarded by a committee consisting of the editors of the leading newspapers of Minneapolis, who examined the certificates and submitted the following report:

\section{REPORT OF COMMITTEE OF AWARD LINCOLN OAT COMPETITION.}

\section{Messrs. Northrup Braslan Gomblum Co.. Minnoapolis, Minn,} GENTLimEN:- Below find a itatenicnt showing the names of those who secured the largest yi

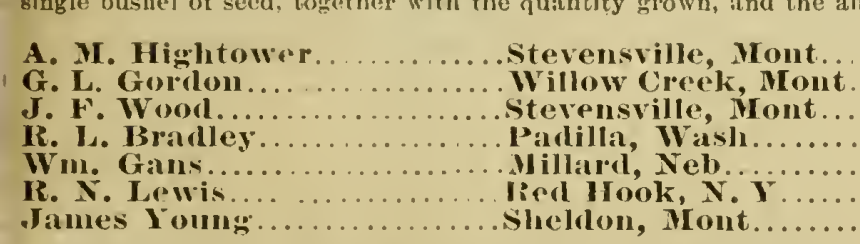

Machino Mleasure
149 bush.
132 bnsh.
103 bish.

$\ddot{79}$ bisisi.

(is $1 / 8$ bus.

(it bush.

$\begin{array}{cr}\text { Measnre by Weight. } & \text { Amount. } \\ 174.19 \text { bush. } & \$ 210000 \\ 168.22 \text { bush. } & 10000 \\ 1 \% 3.08 \text { bush. } & 7500 \\ 120.13 \text { bush. } & 6000 \\ 78.18 \text { bush. } & 3500 \\ 76.16 \text { busll. } & 2000 \\ 75.21 \text { bush. } & 1000\end{array}$

$\begin{array}{rr}174.19 & \text { bish. } \quad \$ 20000 \\ 168.22 & \text { bush. } \quad 10000\end{array}$

123.08 bush. $\quad 7500$

120.13 bush. $\quad 6000$

76.16 bush. $\quad 2000$

35.21 bush. $\quad 1000$

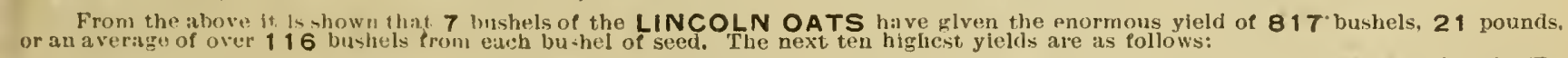

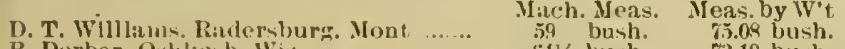

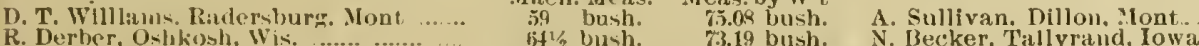

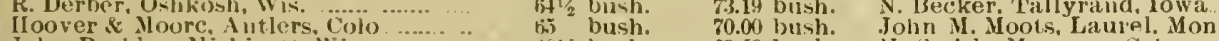

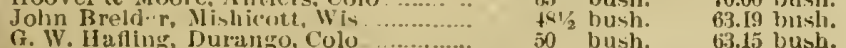

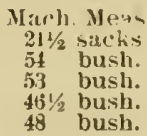

11. Smith. Manassid. Colo

Ieas. by Wht
$62 .+2$ bushl.
60.24 bush. . 18.08 bush. 56.21 bush.

We also note that you have verifled by careful inqulry the statements made by these partles, and that the successful competlors are eully and fisiry entitfed to these awaris is apparently beyond question. We have examined with interest the expressions of satisfaction

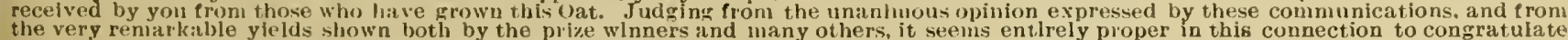
you on having been able to disceminiate a variety of Oats that hals alrearly proven itself so valuable.

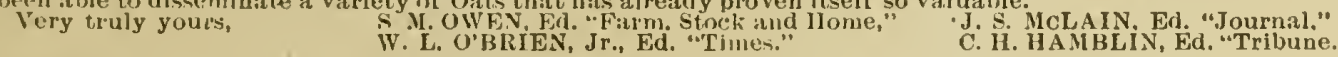

On the same day we mailed our checks for $\$ \mathbf{\$ 0 0 . 0 0}$ to the parties designated by the Committee.

Note the Important Fact that the Oats Weighed nearly 100 Bushels More than they Measured.

\section{HOW THE OATS WERE GROWN.}

As space does not admit the printing of the great number of letters we have received foom those who have grown the Lincoln Oat, we have prepared a pamphlet giving the experiences and opinions of mally who have tested them. Also letters from the prize winners telling "How They Grew the Oats that Won the Prizes." This interesting and valuable pamphlet will bo sent to every one ordering Lincoln Oats, and should be read by every farmer.

Price of Lincoln Oats. $-\$ 1.50$ per bu. of $32 \mathrm{lbs}$. delivered to R. R. Minneapolis; sacks included. 

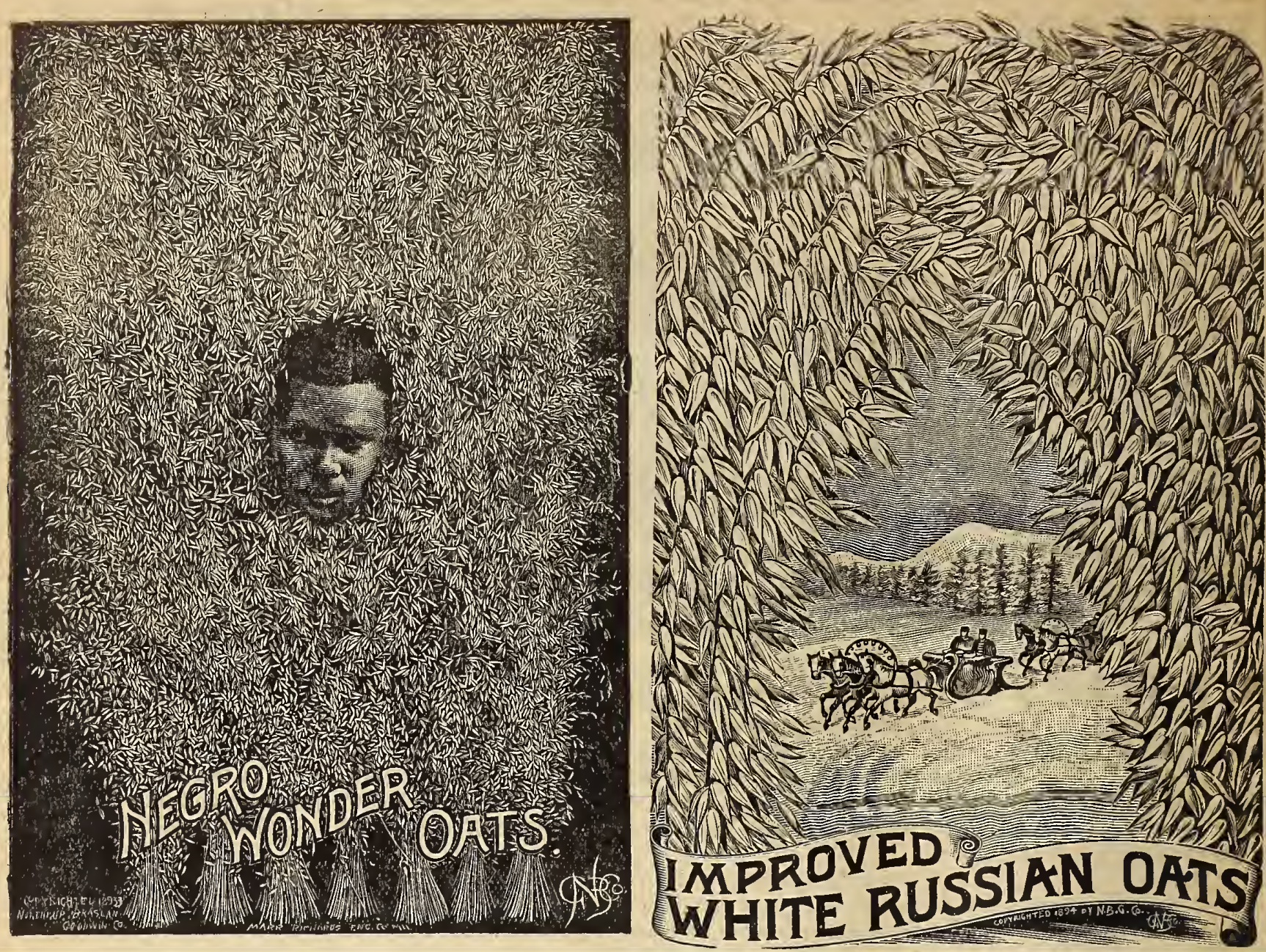

We submit as a straight, plain, business proposition to which all thlnking, intelligent farmers will accede, that a change of seed from the proper source is not only a true principle but an absolute necesslty in successful farming. Another principle equally well established is, the further North seeds can be grown In their full development, the better tiney are. The Northwest is famous for lts cereals, and we have taken such advantage of our location as to become the Iargest growers in these lines of any house in the United States. We ask our customers to consider these facts, examine our prlces, and to remember that If any seeds recelved from us are not found satisfactory on receipt and examlnation, they may be returned at our expense and money that has been paid for same will be refunded.

THE NEGRO WONDER OAT. Thele has of late years out by the trade generally have not given the best of satisfaction, owing to the fact that, as a rule, Black Oats seem to be defieient in come in the Negro Wonder Oat, originated by Mr. Beagley, the Illi-
nois Corn and Oat speelalist, from whon we have secured control of the entire stock. Mr. Beagley nlakes the following statements a bout crop fully matures before the hot suns affect it. Second. It has der ordinary farm cultivation. For several years it has yielded from us, and we have grown all the old varieties and nlany of the newer us, and we have it gave the largest yield in experlnients with sixtyeigit other varieties. Third. This Oat will stand up on any soil, make for this sort. Nothing short of a tornado or a cyelone wlll
lodge then. The straw is fine, but very strong; stools a great deal. lodge thenl. The straw is ane, but very strong; stools a great deal.
Average height 42 inches: about 2.000 lbs. straw to the acre. It was
ane of the very few that gave $\mathbf{1 0 0}$ per eent standing grain when harvested. My mainclain is that the Negro Wonder oat has a larger percentage of kernel in the berry than any other in the market. we have no doubt that the Negro wonder is a first class variety. The Negro Wonder may properly be called a Gray Oat, and to purchase. Price, $1 \mathrm{~h} .25$ cts.; post paid. Peck, 50 cts.; bushel, $\$ 1 ., 5 ; 2$
bushel, $\$ 3.00 ; 10$ bushel, $\$ 12.50$. Bags included. IMPROVED WELCOME. This has become a standard variet y: and is valuable for its earliness and productiveness. It is not
th goor for feeding as sonie other sorts. owlng to the thickness of hull. etc. Nevertheless, its other excellent qualities entitle it to
ploninence. Large pkt., 10 cts.; lb., 20 cts., by mail. postpaid. By express or Preight, lh., $10 \mathrm{cts}$; peck, 40 cts.; bushel., $\$ 1.10 ; 2$ bushels
\$1.75; 10 bushels at $75 \mathrm{cts}$. Bags lncluded.
WHITE RUSSIAN, The original stock of White Russian Oats was really a capital Oat, and sprung immediately into great through not botn customer of ours in Dakota, we are able to offer the Wiite Russian White Russian is as ne. It is a well established fact that the true are confident that niany will hail its re-introduction with satisfaetlon.

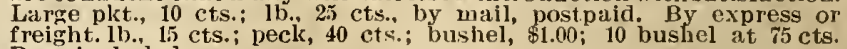
Bags EA ARCHANGEL: Note. This Oat has fully sustained very claim niade for it. It has never failed to give perfeet satisfaction. The original stock of this Oat was obtained from Archangel, eountry has been grown with great suceess. It has proven itself to eountry has been grown with great suceess. It has proven itself to does well on light soil. and is a most satlsfactory $O_{a t}$ in all respects. Its prlncipal attraction is lts extra eariiness; and by this quality it escapes many of the ills which Oats ale heir to. The straw is stlff, well glazed, and erect. The grain itself is plump, heavy, exceedingown glowth from the original stock. Larte pkt., 10 cts.; 11 ., $25 \mathrm{cts}$., by majl, postpaid. By express or freignt, lb., 15 cts.; peck, 40 cts.; GOLDEN GIANT SIDE OATS. Excite wonder wherever then. Note. This is not an early Oat, but in other respects is one of these Oats growing wants snne of then. We again bring this Oat to the notice of our patrons with the assurance that those who test it Will find it in some respects the most remarkable oat of recent in troduc. 18 ine fies in length, and usually contain fonditons vary from 3 a to actual count. They stool freely, and while they are not an early, variety. for size of grain and head and enormous ylelding quality, they Ly far surpass any other variety with which we are aequainted. cts.; peck, $50 \mathrm{c}$.; bu., $\$ 1.50 ; 2$ bu,, 20.50 ; 10 bu. at $\$ 1.00$. Bags inciuded. 
BARLEY.

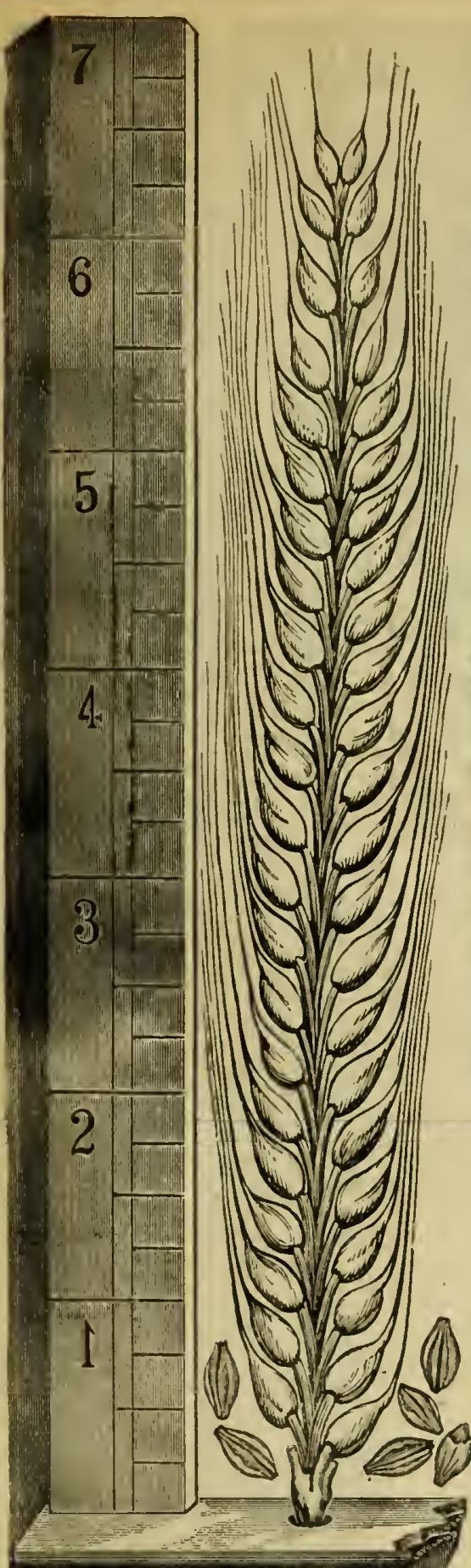

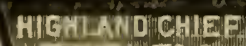

A.MPROVED BLACK BARLEY.

pose conchually recelr Ba pous do to the imeasured bushel.

larger quantlty of any other barley.

ts. by where le has ralled to lully satisy the

\section{MANSHURYBARLEY}

Earliest, Strong Strar, Heavy Gropper.

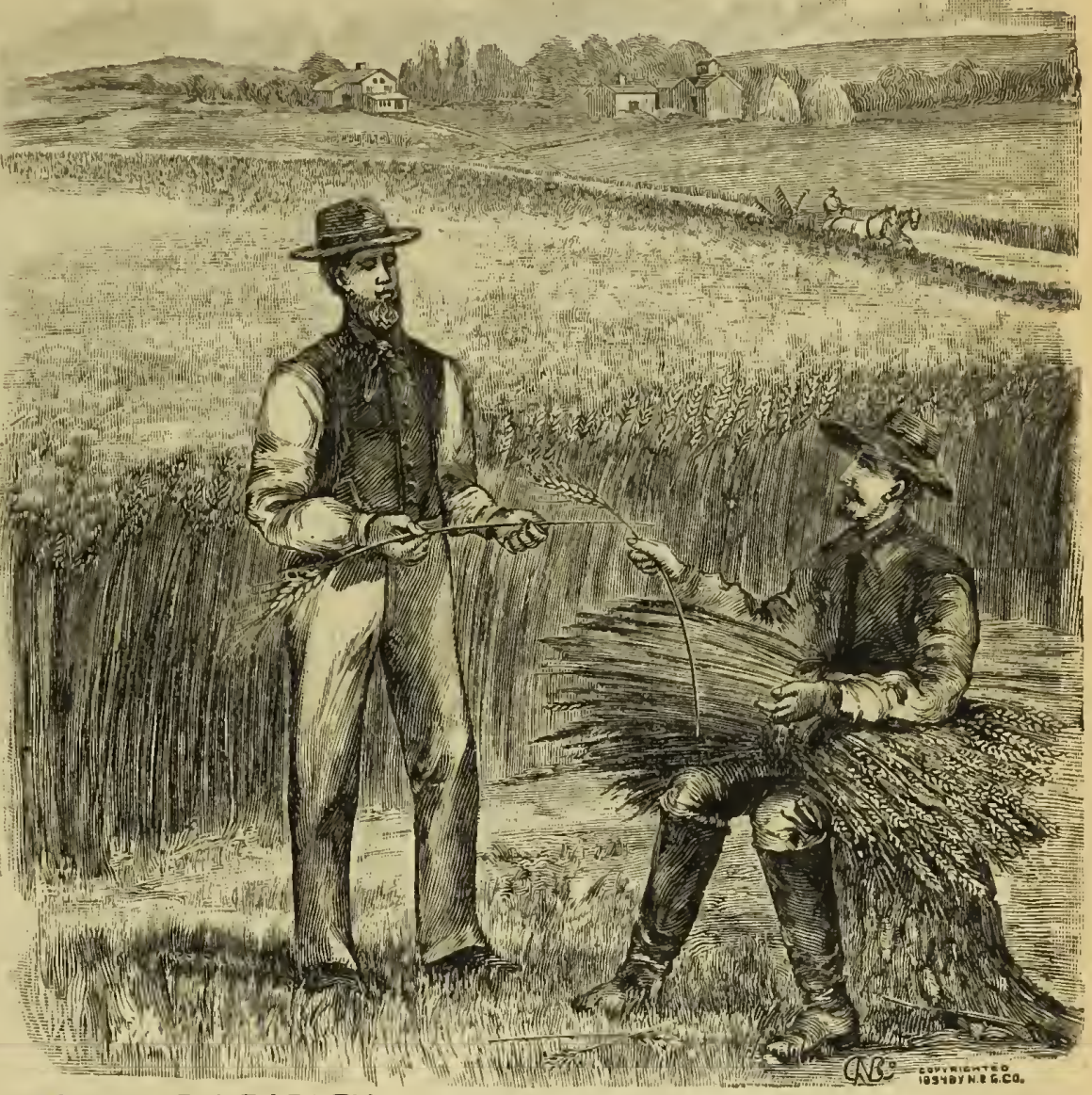

MANSHURY BARLEY. ThIs Barley was first disseminated in smatl quantities

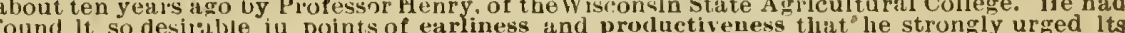
use. At hls suggestion. we some yeirs ago secured usmall quantity of the seed, and have

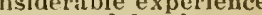
in growing Balley, and froin the favorable opinions that have been expressed by those to or ever saw. We hive intended for the list two or three years to brini it more particularly to the attention of our customer's, but we have been unable to do so through lack either of

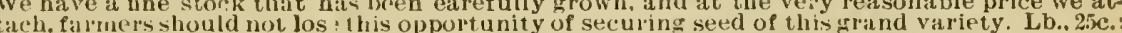
HIGHIAND CHIEF BARIEY. years ago and lt has excited more remark than any Fietd seed we ever offered for sale, parrols ts other merits, for it is not only several years ato sent a sample to the head of the largest firm of Malsters in the Unlted ness, he had never son such a handsome sample of Barley." The IIIGHLAND CHIEF is a vighely 10 be dimiared by wet than inost other klnds, as it is much more clnsely covered wlth productive, and usually weirhoruite $50 \mathrm{lbs}$. to the measured busliel. Large pkt., 10c.; 1b., 25c. postpaid. By express or freight, peck, 60c; ; bu., $\$ 2.00 ; 2$ bu., \$3.00; 10 bu.. \$12.50; bags Included. ing as we do each year a great variety of seeds, we are in a position to judge from the reports proving of greatent value to the growers. We are thoroughly convinced that for Feeding purcustoner, One and one-lialf to two bushels should be sown to the acre. Pkt.. $10 \mathrm{cts}$; ; $1 \mathrm{~b}$., 25

L. H. PATTEN, Forman, N. D., writes: "The bushel of LINCOLN OATS that I purchased of you last spring was the best investment in the line of seed grain that I ever made. I consider the LINCOLN OATS superior to any other va. riety 1 have ever grown, or seen grown, in three respects: First-The LINCOLN OATS will yield more to the amount of ground than any other oats that can be raised. Second-The LINCOLN OATS will yield a better quality of oats than any other variety that can be grown in Wisconsin, Minnesota or the Dakotas. Third-The LINCOLN OATS will yield a better quality and give a heavier yield of oats in the Northwest simply because they will stand more drouth and are especially adapted to the Northwestern climate. Being deep rooters, they stand heavy drouths. 


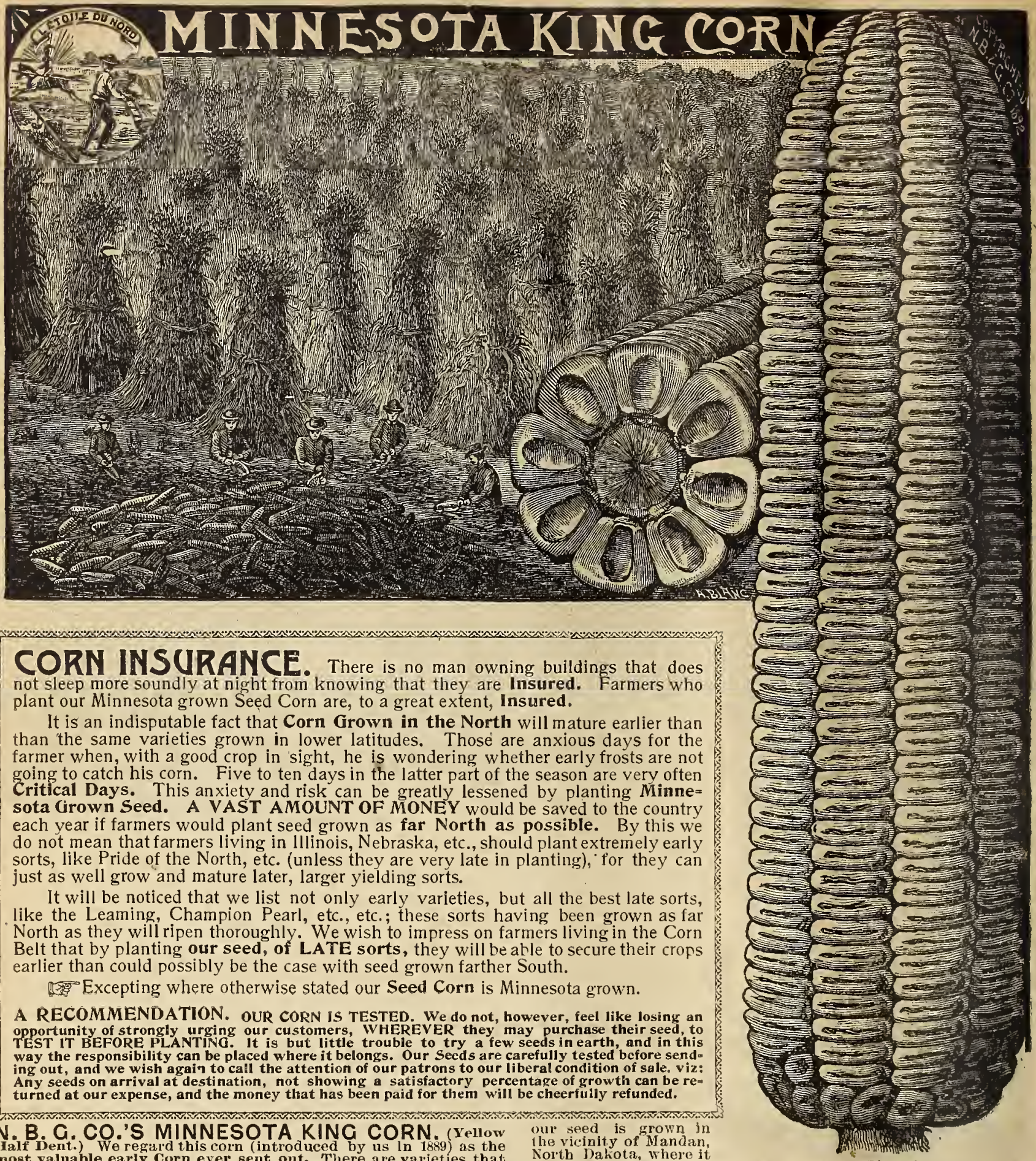

N.B. G. CO.'S MINNESOTA KING CORN. (Yellow most valuable early Corn ever sent out. There are varieties that year in and year out, through fat years and lean years, there is. we believe, no sort that will do as well. It seems to possess a taculty of
growing riglit along and making a crop during weat ther and under conditions that would ruin other varicties. We do not lnow of any good reason why this should be so. but not only is this our own experience, but we have received llke testimony from hundrcds to whom
we have sold it; the unlversal expression being that for ability to endure extremes of heat and cold $₫$ fiood and drought it has no equal. In appearance the Minnesota King is remarkably distinct, being a rich yolden color. The ear is of good size, eight rowed, cob stnall.

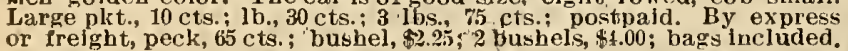

NOTE. -Thls corn was introduced by us several years ago, and although each season we have anticipated the large sale which it has met by what we consider liberal provisions, we have never as yet been able to supply the demand, having returned money yearly to late purchasers.

SQUAW CORN. (White.) Early Flint Varietles (in order of earllness.) This is not a satlsfactory variety to grow where other corn will mature, but it is invaluable for extrenie northerly points. A good idea of its earliness can be gained front the statement that
The vicinity of Mandan,

matures perfectly. 'Tile stolk is very dware. Pkt $10 \mathrm{cts}$, th $20 \mathrm{cts}$ posipaid. By express or freight, peck, 75 cts.; bushel, $\$ 2.00$; 2 bushels, MERCER. (Yellow.) Early, prollfic, good size ear and-small cols Has been grown in this state for the past tye years with great succes and complete satisfaction. Very prolific, laving ylelded 164 bushels
of good sound ears, to the acre and wcinhs biths to the shelled bushe Ear's average from nine to eleven Inches in length. twelve to fourtee rowed, well filled out to the tips, and of a rieh golden yellow color has natured in 75 days from the time of planting. Many stalks have

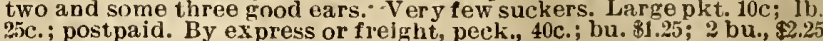
LONGFELLOW. (Yellow.) This is an elght rowed corn of the Canada type, the ear cyllndrical. about nine inches long, the colo

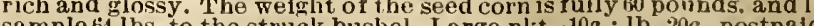

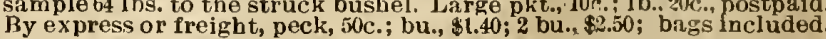
MINNESOTA WHITE. (FInt.) This is an cight to ten-rowed white flint corn, wlth short well shapdd ears a nd small cob. The stalk bear from 3 to 5 ears, the ears are small in size, kernels are hart an compactly placed on the cob. Large pkt... 1nc. Ih.; 20t.. postpald. B 
CORN.

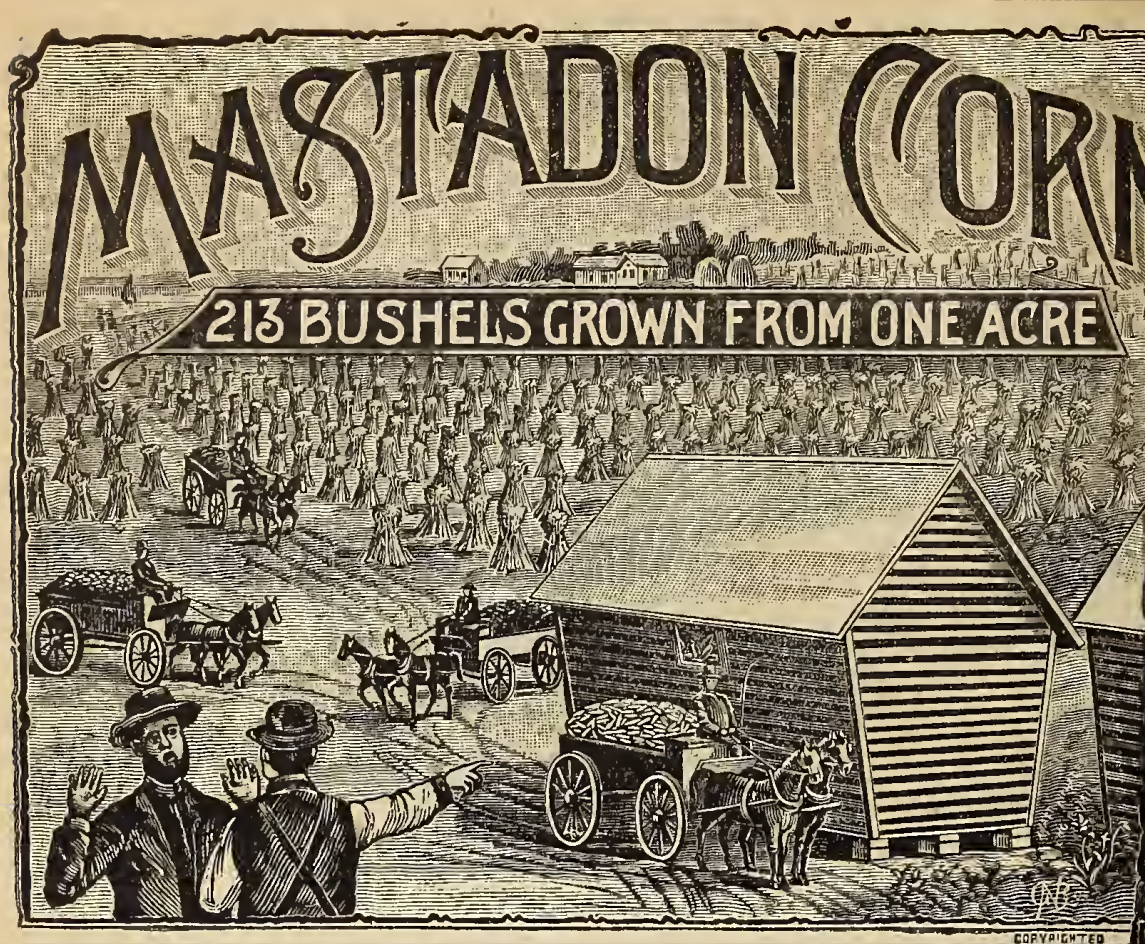

A PERPLEXED FARMER is not a rare sight, but this condition of mind does not often arise through having such a large crop that he does not know how or where to house it. There would be many such cases however, did all have the same good fortune as that experienced by Mr. Alfred Rose, of Yates county, N. Y., who raised on ONE ACRE of MASTA= DON CORN 15,898 POUNDS OF CORN ON THE EAR which made 213 BUSH. ELS of shelled corn.

The originator states: "The Early Mastadon Corn, named Mastadon because of its large ears, is a cross between the Wlite Cap and the Early Roe Dent Corn. and has been of field corn have for many years been anxiously inquiring for a large-ealed, yet early Dent Corn, and to supply their wants I have for years been studying it up, and until I got the Mastadon your custorrers will find a high-bred corn, of beautiful color, and one Which will please them. I claim for this corn the largest number of rows on cob, and the
deepest, longest grains of any corn ever originated, making the finest appearing shelled corn l ever sidw, being a cast of two colors, and such corn as brings the highest price in strong and rank, ata medium height, and will out-yield any corn ever grown in this section. To convince your customers of its earliness, tell them lt was grown and ripened in
irom 96 to 100 days within eirht miles of Lake Erie. Fields planted J une 1st we re september 15th. You cannot too highly recominend this corn to your customers. My reputan as the largest grower of seed corn in this country is at stake. When I say to klze and number of rows on the cob. I have grown thousands of bushels of Golden Beauty and now have many tields under contract; the Mastadon is from three weeks to Corn is flom one week to ten days earlier than the J.S. or any other Leaning Corngrown, erwise, when lt is crossed with two of the earliest corns ever grown in the North-the 81.09 postpaid. By express or freight, peck, $60 \mathrm{cts}$; bushel, $\$ 200 ; 2$ busliel, $\$ 3.50 ; 10$ bushel.

Our readers will notice the claims made for earliness. Mastadon is very early as compared with Golden Beauty, Leaming, and other standard sorts so largely grown in the corn belt. It is not as early of course as Minnesota King, Huron, Dakota Dent, etc.

\section{STANDARD LATE VARIETIES.}

GOLDEN BEAUTY. Yellow Dent. The largest graln yellow dent corn in cultivatlon; the ears are large, of perfect shape, and in every respect present as perfect a type cob; grows eight to ten feet high; matures medium early. Not recommended for the our nwn growth, and is the handsomest yellow dent corn ever seen. Sunple sent on refreight, peck, $40 \mathrm{cts}$; bu., $\$ 1.25 ; 2$ bu., 2.25 . Bags lincluded.
IMPROVED LEAMING. Yellow Dent. Ear's of good size, cob red and small, with a deep, large grain of bright yellow. It is an early vilriety, ripening in 90 to 100 ditys from time of planting; a strong grower, and producing well on light or heavy land where other
varieties of yellow dent would not thrive. Large pkt.. $10 \mathrm{cts.}$ ib., 20 cts., postpicid. Ry CHAMPION PEARL. White Dent. A white pure dent corn, exceedingly henvy. very compact, very prolific; will grade No. 1 white in any inarket; cun be plinted tlileker than large corn, and bear full sized ears. The stalk ls short and thick, roots deeply, ear

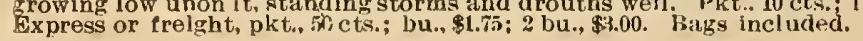

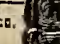

\section{(5)}

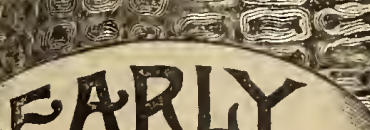

EARLY TU:

The

2 MASTADO

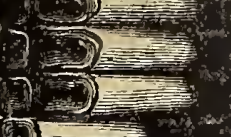

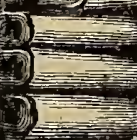

3

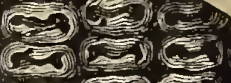

$\Rightarrow 30$

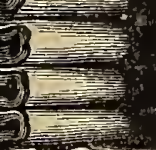

(3) 1 -

(a)
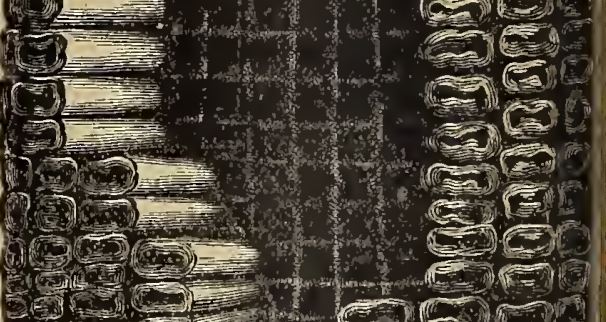

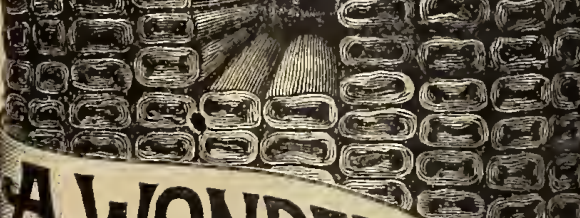

AWONDER

AT:

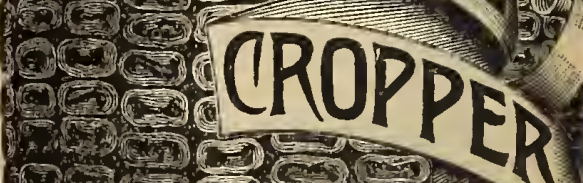

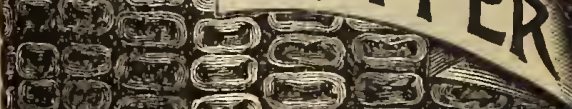

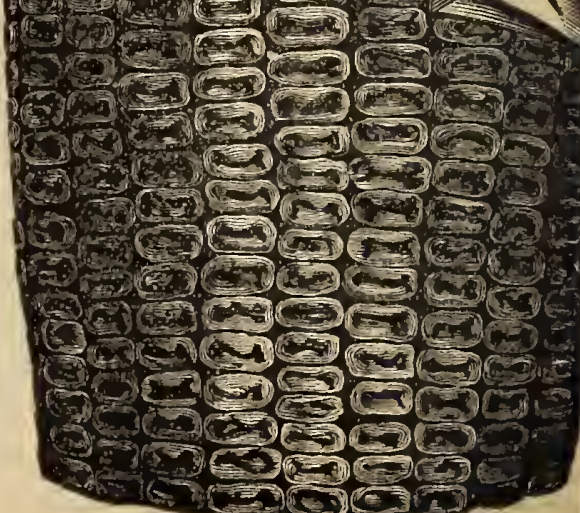




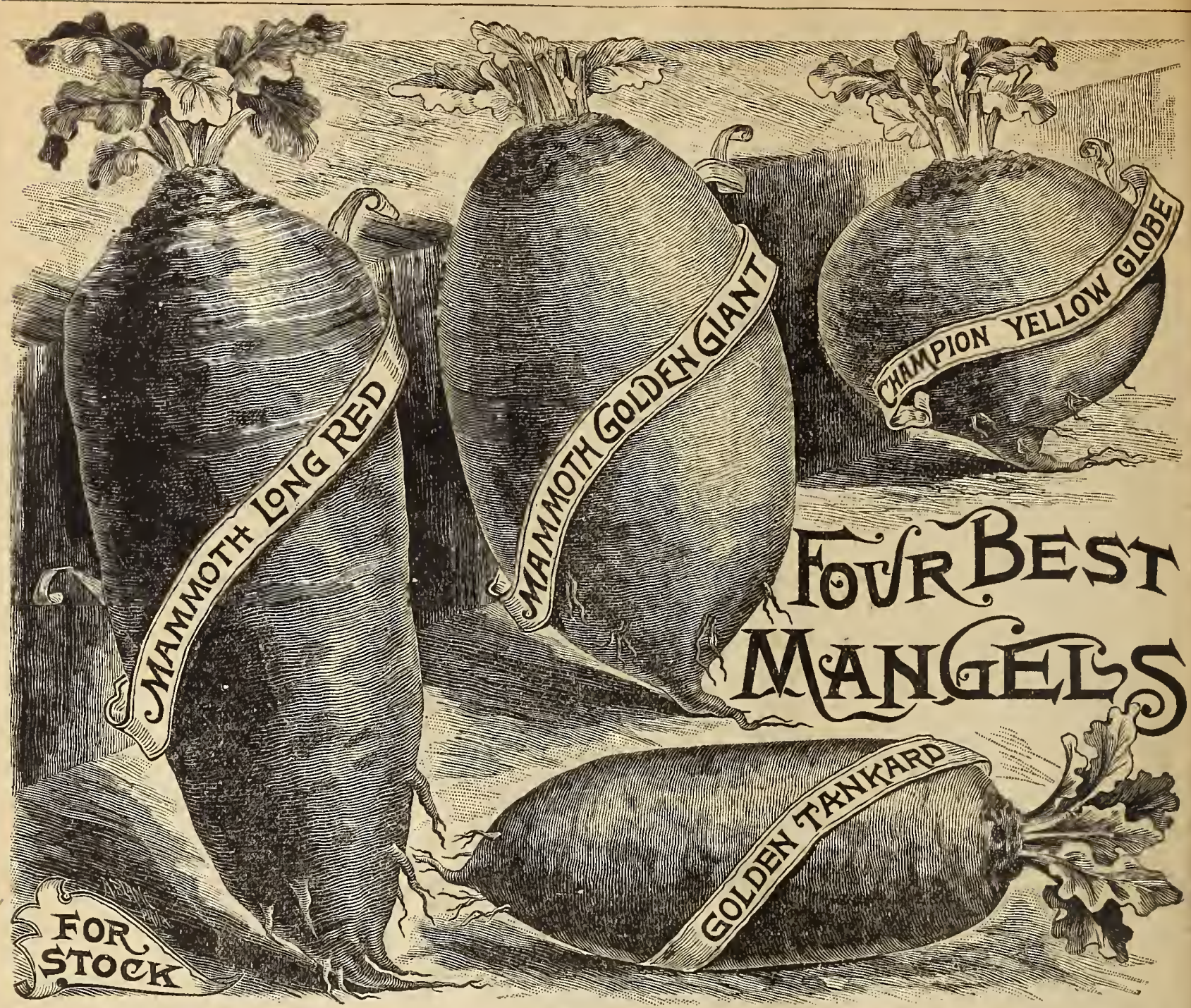

\footnotetext{
The following statement from one of the most prominent authorities on Agriculture in the Northwest speaks volumes in show'ing the superior quality of Our MANGEL and other ROOT SEEDS:

"For the past eight years I have used your seeds with the greatest success. I wish especially to commend your MANGEL and RUTABAOA SEED as the BEST I EVER USED. My experience in farming covers a period of over 20 ycars, during which tume 1 have rarely cultivated less than TEN TO TWENTY ACRES OF MANGEL WURZEI. AND SWEDISH TURNIP. As a stock breeder, I have always considered them my most important crops. Thave bought seed from nearly every prominent house in the United States and Canada, and sometimes have imported it direct
from England, but NEVER HAVE I HAD THE UNIFORMLY GOON RESULTS THAT YOUR SEED HAS GIVEN ME. In North Dakota, where I had from England, but NEVER HAVE TAD THE UNIFORMLY GOON RESULTS THAT YOUR SEED HAS GIVEN ME. In North Dakota, where I had the largest herd of thornughbred cattle, I AVERACED FROM TWENT TO THRT TONS OF ROOTS TO THE ACRE. Later, AS manager of Mr. J.J. Hill's stock farm at North Oaks, my tonnage was not quite as heavy, owing to the lighter character of the soil, but in SHAPE, SIZE and UNI
FORMITY the roots have always been as nearly perfect as any man could wish."

NOTE. - We value very highly the above expression from Dr. Alloway, who was State Veterinarian for North Dakota for tliree years; for a ong time President of the Fine Stock Growers' Association of North Dakota; Lecturer to State Agricultural College, at Brookings, S. Di; Director in Grand Forks County Agricultural Society, and one of the largest, most progressive and successful stock breeders in the United States.
}

- MAMMOTH GOLDEN GIANT MANGEL. An improvement on all other Yellow Mangels, being of considerably greater size growth; it has a fine neck and a very smooth skin. Flesi, white, firm and sweet, much liked hy cattie. 1n short, a, magnificent root. easily F́ cts., postpaid. By express, $1 \mathrm{~b}$., 45 cts.; 5 lbs.. at $40 \mathrm{cts}$. per lb.

RED GLOBE MANGEL. Similar to the Yellow Globe in general character, and like it, well adupted to shallow soils. Oz., 10 cts. Ab., $20 \mathrm{cts}$; lb., $40 \mathrm{cts}$. By express, 1b., $30 \mathrm{cts}$.; 5 lbs. at $25 \mathrm{cts}$.

- NEW GOLDEN TANKARD MANGEL. This is a distinct and superior strain of the Yeliow or folden-fleshed Mangel. On ac.

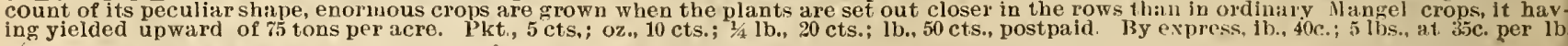

- UMPROVED MAMMOTH LONG RED MANGEL. Growing to an immense size, has produced 65 tons per acre. 0z., $10 \mathrm{cts}$.

VCHAMPION YELLOW GLOBE MANGEL. A favorite variety, very productive, easily pulled ind a good keeper, It is spherical in shape. orange-yeliow color, top tinged with green; flesh of the root white, firm and sugary. Oz., 10 cets.: 2/4 lb.. $20 \mathrm{cts}$.: $1 \mathrm{~b}$.., $50 \mathrm{cts}$., post-

\section{SUGAR BEETS.}

N.B. G. CO.'S CHAMPION SUGAR, This is an improved variety from firance, and allords the laryest percentage of sugar tons to the acre. Roots very symmetrical,being about three to four inches in giameter at, the shoulder, tapering graduaily to a point, growing slighty above the sulface; white, washed with red at the top; flesh fine By express, lb., $50 \mathrm{cts}, ; 5 \mathrm{lbs} .$, at $40 \mathrm{cts}$.

LANE'S IMPERIAL SUGAR. Has yielded to tons per acre: the most popular sugar beet. for feeding. Oz., 10 cts.: $3 / 1 \mathrm{lb} ., 15 \mathrm{cts}$; $1 \mathrm{~b}$. 40 cts.. postpaid. By express, lb., 30 cts.; 5 lbs.. at 25 cts. 


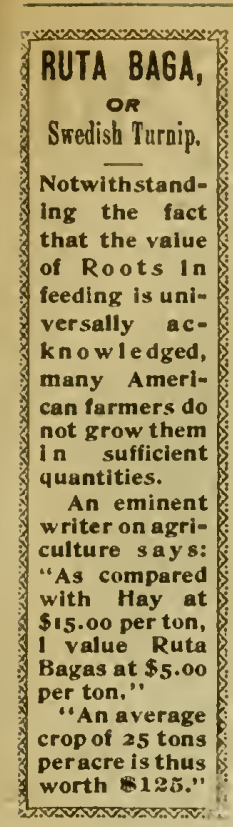

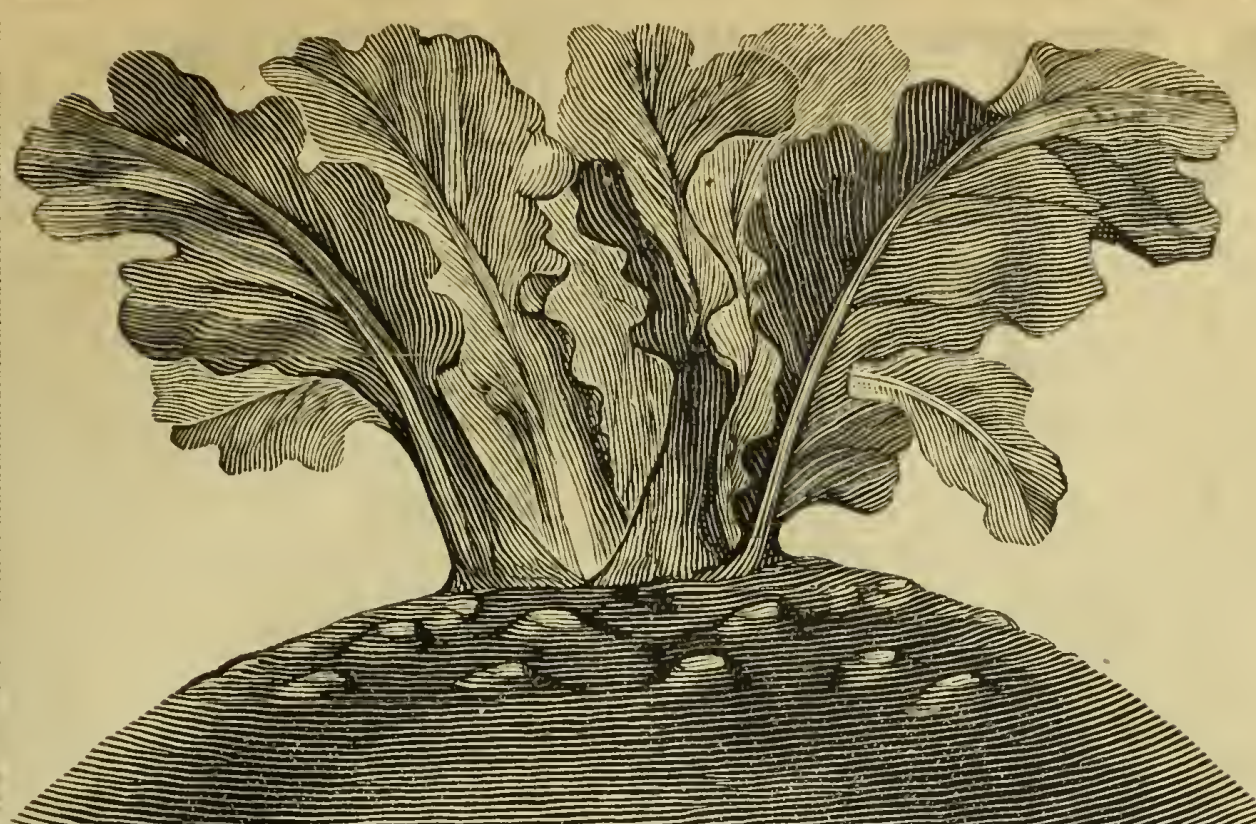

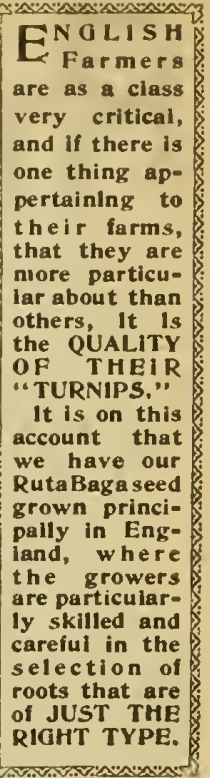

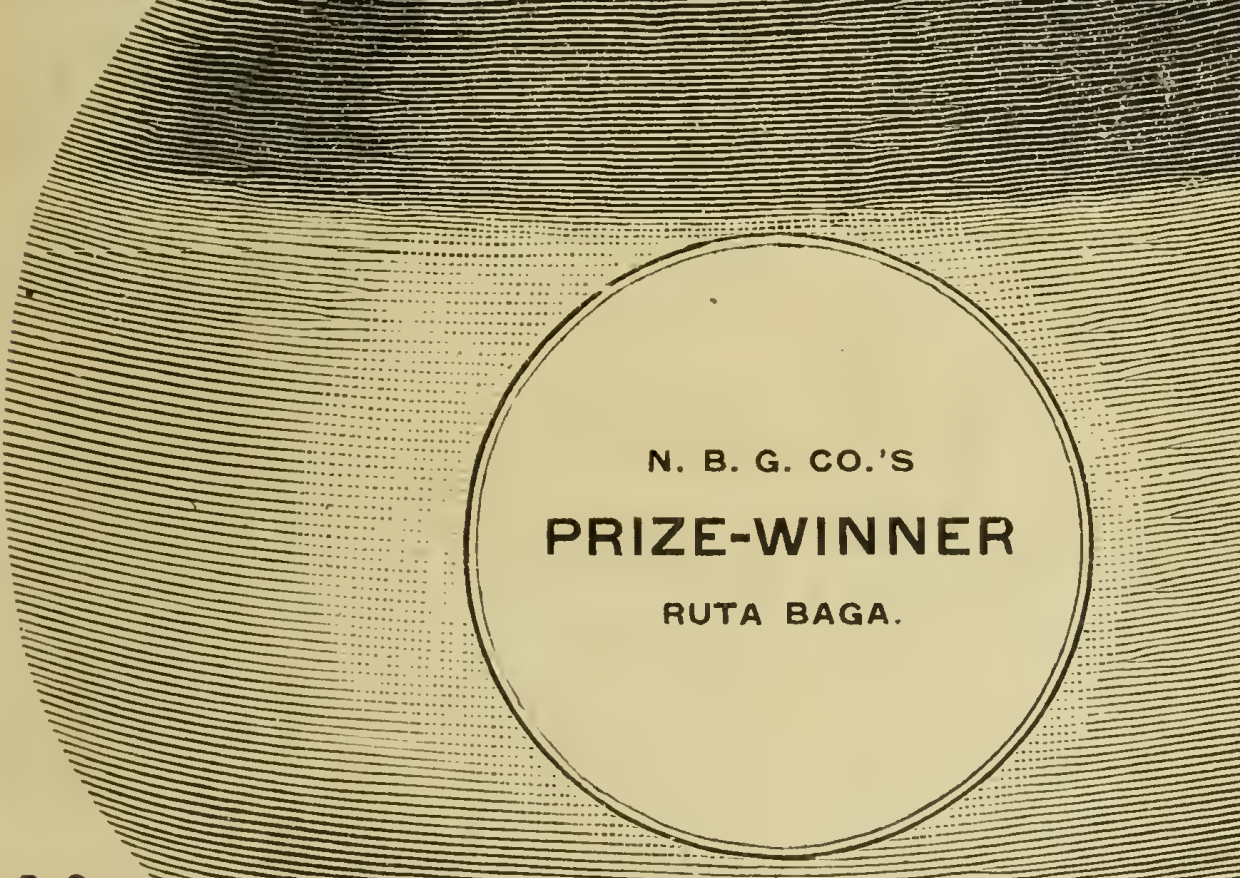

N. B. G.

CO.'SPRIZE.

\section{SWEET}

GERMAN

\section{WINNER RUTA}

\section{BAGA. Prize-Winner}

is a purple-topned varlety.

yrowing to a large size, with a

single tip root and very small

and fine top, shurt neck, smooth and

symmetrical. It has a remarkably ro-

bust coustitution, is a certaln cropperi and

where left in the ground has stood the severe test of tho hardest winters better than any other "iricty. It produces is very heavy weicht per aere, and kreps sound and good untll late ln the spring. From reports recelved from those who have grown

our I'rize-Winner, wo do not hesitate to sity that we cousidker thls the Ilandsomest and Best stock of purple-top Ruta

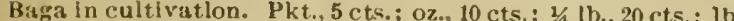

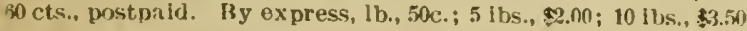

CARTER'S HARDY SWEDE. A standard variety. a favorlte sort in England. Highly reconmended as producing extraordinary crops. Pkt., 5 cts.; oz, $10 \mathrm{cts}$; $1 / 4$ th., 15 cts lb., 50 cts., postpald. By express, 1b. 40 ets ; 10 lbs.. 33,00 his conslderation should coun trongly with stock growers, all ity of the understand that the qual lty of the product. Pkt, 5 cts,; oz ide. lbs. at 40 cts. per ib.

HURST'S MONARCH SWEDE.

We first saw this splenclid variety ln Eugland and wele the first to bring lt to the attention of the merican tracie. It is very distinct in type. being of tankarcl shape. On account of the slze It attains. It wlll yleld from two to seven tons more to the acre than any other variety. The Hesh is very firm and fine. Pkt.., 5 cts.; oz. 10 cts.; 1/6 lb, 20 cts.; 16., 60 cts., postpald. By express or frelght .0 cts; 5 lus, at 45 cts, per th.

STODDARD BROS., of Hunter, la., write: "The seeds purchased of you lust spring were just as you represented them to be and all came up. 

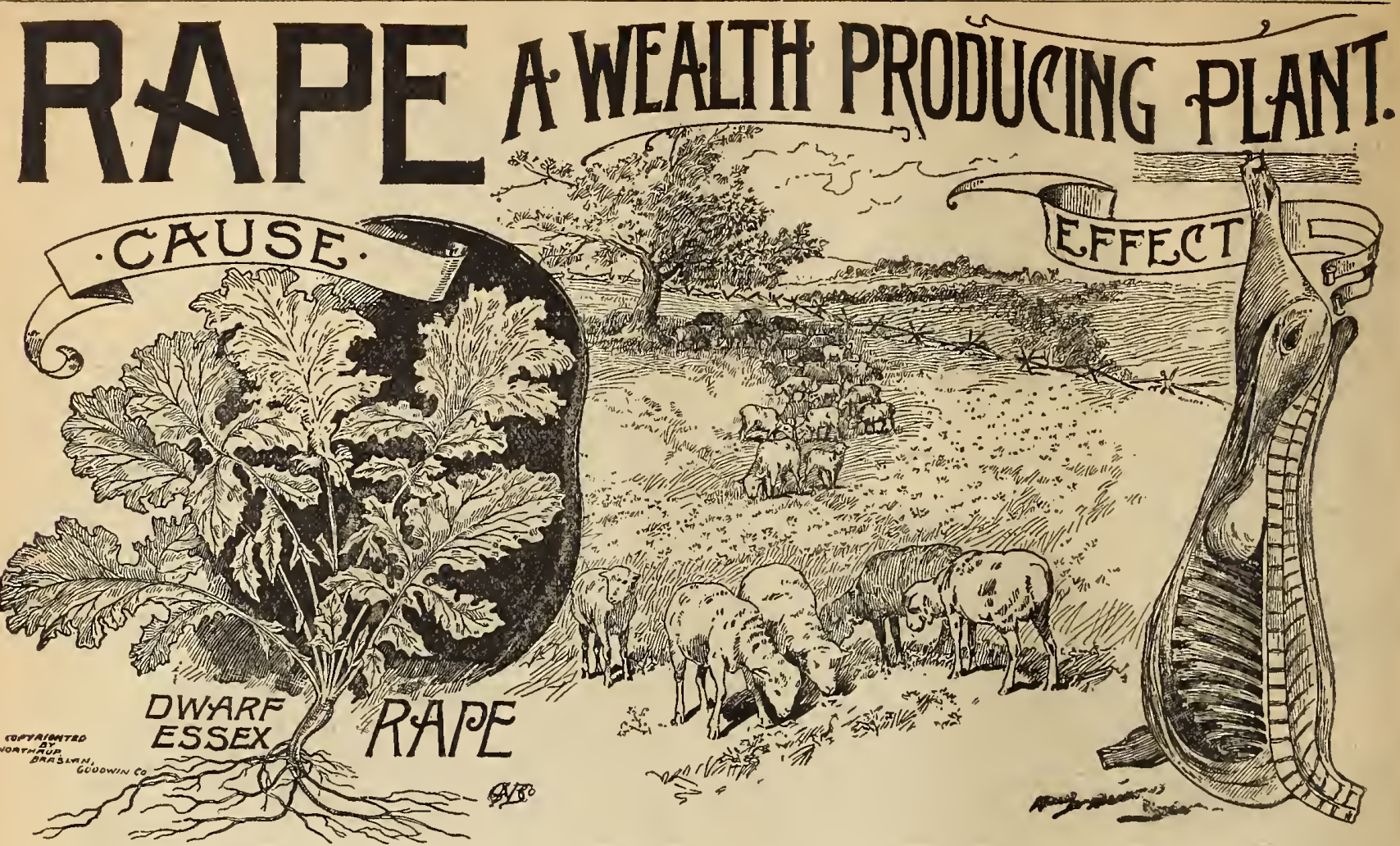

NEED OF THE RAPE PLANT IN THE UNITED STATES.

After corn ho Reen harvested, and before the setting in of winter. there is a season dur'ing whicin farnucr's are obliged to depend sojely upon grass as a source of food for their flocks and herds, unless winter siores are drawn upon to feed them. The ncerl of sonre useful fodder plant that will furnish abundant suppiies of nutritious fodder at that season has long been reesgnized. This want has becn more sequence many millions of sleep and Laubs are put upon the market during the aut.1mm months in an nnfinished condition, to the
great loss of the owners and, in the end, to the great loss of the nation. Shaw, reccntly Professor of Agricul1ure in the Ontario Agricuitural Coilege, but now connccted with the Mlinnesota Agricultural Collcge. as well as by thousands of farmers who have experimentcd for themeasily grown in nearly all portions of the United States and that it Will furnish abmndant supplies of succulent, rich and nutritious pasture at the season of the year when it is sorefy necded. The Rape plant is possessed of lemarkabe fiattening properties. When sheep

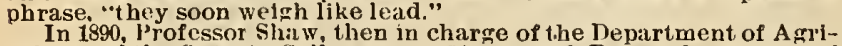
culture of the Ontario College, Grew 54 acres of Rinpe after a crop of Rye. In the autinnin of tilat year, 5.37 sheep and Lanibs were fat-
tened upon the Rape; elghteen head of Stecrs fed upon it for 59 days and several acres were still left uneaten when winter cilne. In 1891 , 40 acres of Rape were grown; it aiso came after $k y e$, wlich had been cut about June 1st and cured for fodder. No fewer than 666 Lambs fattened upon it from two to two and one-half months. Profcssor" Shaw further stat ces: First, "that one acre of Rape can pastiule 10
to 16 head of Lanns from two to two and one-half month, when Rye, grown for fodder, his preceeded the Rine the same season. Second, that wilen grown on giound that his not becn cropped plcviousiy the same season, one acre of Rape will pasture 36 to 37 head

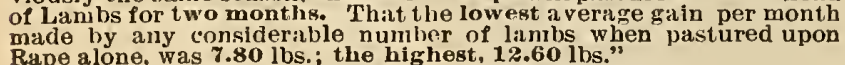
mape alone, was 7.80 lbs.; the highest, 12.60 lbs."
THE GROWTH OF RAPE.

Rape will grow in any soil that wlll produre an abundant crop of Turnips or Corn. Muck swamps, particularly, when drained, are PREPARATION OF THE SOIL.

Three methods of drills, in drills on the level, and lroadeast. the object sought, as to which of these methods are preferable in specific cises. as with Corn. The growth is stinulated in proportion to the anount

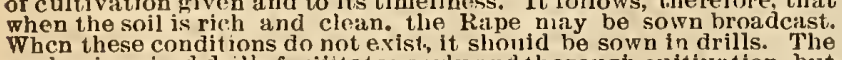
sowlng in raised drills faciiitates early ind thorough eujtivition, but the seed is more certain to germinate when it ls sown in drifls on the
level. The amount of secd to use should be ginged by the condition of the soil and the nature of the weathier. The quantity shoudd be gown brondcist. from three to five pounds are required to the acre; in drills, from one to two pounds. The time for sowling the seed will vary wlth the ohject sought ind
the climate. For soiling purposes, it nlay be sown in May in the more northerly portions. and cut or eaten off when it is sufficiently advanced. It wili grow up again and may be used a second time in the during ther, but, ordinarily the best resulis are obtimed when sown earlier, the hot suns of August seem to unduly hasten its maturlty.

\section{CULTIVATION.}

The cultivation of Rape should commence as soon as it is well started in the rough leaf. and siould be repeated as frequently as possible until the leaves of the lape have so far extcuded over the space between the rows that they would

\section{RAPE AS PASTURE.}

Rape is unequalled is a pasture for Sheep in the autumn; as a fattening food in 1he field it is without a rival in point of cheapness the most effective nanner, and with but little cost to the owner. When Rape is established as a pasture, the necessity for sending When Rape is established as at pasture, the necessity for sending Catile may also be pastured upon Rape, but through treading, they destroy and waste it in a considerable degree. Because of this, it is bet ter to remove then to an adjolning pasture when they have satlsfed their wants. Tle resuits are usuilly very salisfactory when they are pestured upon it in the day only and fed in the stable or shed in the parning before going to the rape pasture. This is an excellent way of nuaking Christmas beef. Rape will keep a long time in early winter in heaps like shocks of hay. When cut and thus put up at the approach of wintcr, it may be drawn and fed as desired.

\section{RAPE AS A CATCH CROP.}

Rape is particularly adapted for belng grown as a catch crop as. like the Turnip, it grows better late rather than earlier in the season, When in grain crop, therefore, has failed from any cause whatsoever, there ls anple time to piow the land and to sow kape upon it. It niay also be sown antong Corn, just before the last cultivation which is to is given to the corn. ground is not sown with Grasses at the sanie time. Ordinarily, the growth of the Rape will not interfere with that of the Gratn crop, and it wlll grow vigorously and furnlsh cxcellent pasture after the graln .

Space does not pernit enterlng as fully into detalls as we could wish. We iave emphasized more particularly its use as a pasture. It is very valuable, however, as a green mauure, and as a cleaning crop, and pronises to be one of the most valuable plants ever introduced into this country. Its uses in the oider countries are well known. and it is a marvel that, it has not been more give it a personal trial the coming season will do so. We anticipate a large s"le of thls seed during the coming season, and to meet it have imported a large quantity of the genuine tand fact ESSEX RAPE. W are several other valleties of Rape sold, but their cultlvation has neve been satisfactin'y. lb., $30 \mathrm{c}$.; $10 \mathrm{lbs}$., at $25 \mathrm{c}$.; $100 \mathrm{lbs}$., at $20 \mathrm{c}$. (25 lb. lots, at $100 \mathrm{lb}$. price.)

ACKNOWLEDGMENT, - in the above description we have quoted freely from the valuable pamphlet, entitled, "The Rape Plant," written by Prof. Thomas Shaw, and published by authority of the Secretary of Agricuiture. Those wishing further information should send to the U. S. Department of Agriculture, Washington, D. C., for a free copy of the Farmer's Bulletin-"The Rape Plant. 


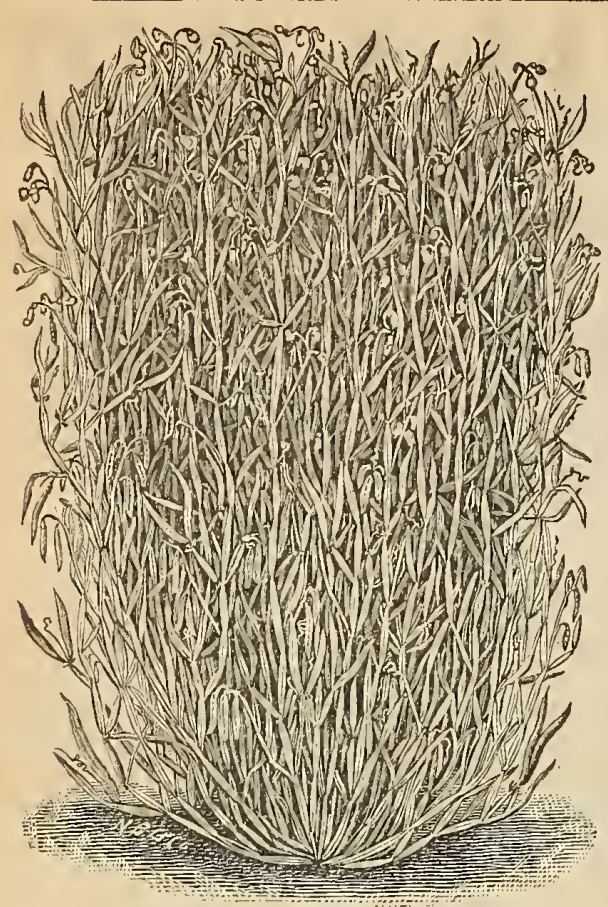

The Lathy rus Plant.

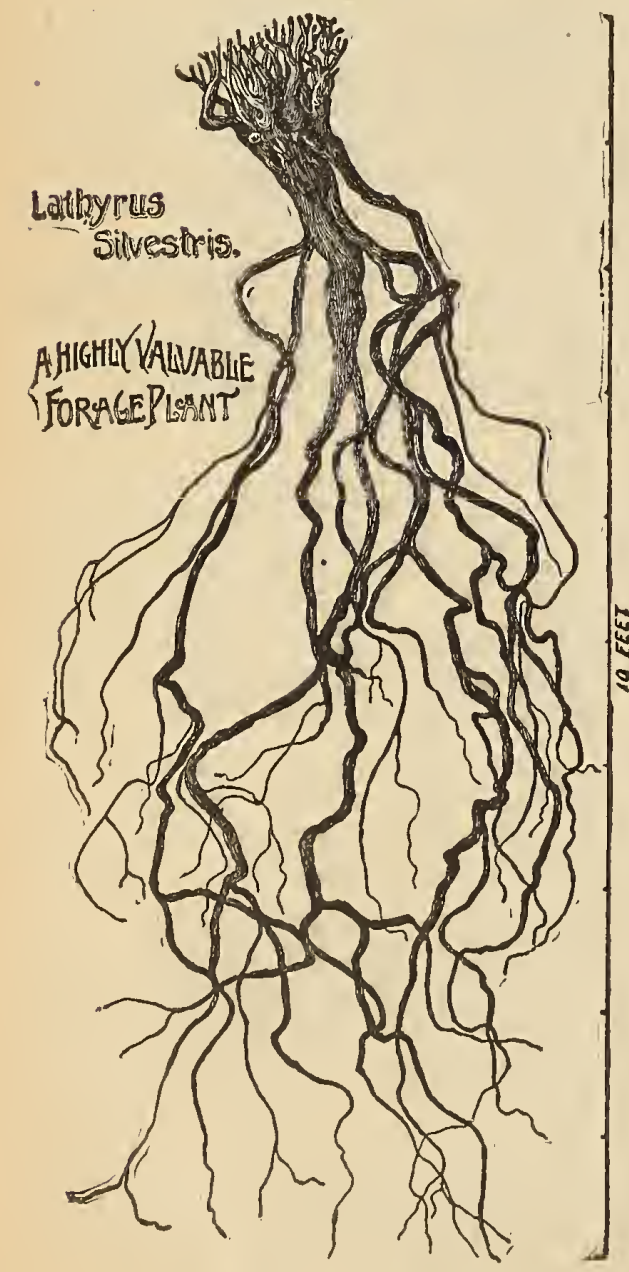

Root of Lathyrus.

\section{LATHYRUS SILVESTRIS.}

THS plant, which is described as an Everlasting Pea, has in its wild state been long known in Central Europe, where it grows luxuriantly in the forests and other unoccupied places. It has been of common observation that game would seek for it at all seasons of the year, even digging it from under the snow in mid-winter. This fact, its long life, luxuriant growth in time of drouth, and other characteristics, led Herr Wagner, of Germany, about twenty years ago, to investigate its merits as a forage plant for domestic animals. In its wild state it contains some bitter elements, which have been entirely eliminated by the careful selection and cultivation of Prof. Wagner, until to-day the improved Lathyrus is the most valuable forage plant in cul= tivation. Comparative analyses find clover hay contains 7.82 pounds of flesh formers in 100 pounds of hay; Alfalfa, 10.71 pounds; Wheat Middlings, 12.18 pounds, and Lathyrus Silvestris, 15.32 pounds.

Not only is Lathyrus the most valuable forage plant for growing stock, but it is the most valuable for enriching the soil with nitrogen. Recent investigations have proved that the power of clover to fertilize the soil exists in a minute insect in the tubercles of the roots. The roots of Lathyrus are covered with innumerable tubercules, and extending thirty feet into the soil as they do, makes it the greatest fertilizing plant known. . This great root development enables it to endure extreme drouths, making it particularly well adapted for the western prairies, or any section liable to drouths.

The plant is perennial, and wild plants are known that are 60 years old. The yield of forage is immense. Four tons of choice hay per acre has been cut at one mowing in the United States the second year from the seed. As two or three cuttings may be secured in a season from the matured plant, a large quantity of very choice hay can be harvested from a comparatively small area of land. This is a fact of great importance to dairymen particularly. As Lathyrus is so exceedingly rich in nitrogen, straw or other coarse fodder is required to be fed with it to secure a balanced ration for most stock. Farmers will readily recog. nize the benefits on this account, as it enhances the value of all their coarse byproducts.

CULTURE. Sow in drills two and one-half feet apart, four to six inches apart in the drill, and three inches deep. Cultivate thoroughly the first season, keeping the weeds down. The seed is very slow in germinating, requiring three or more weeks, and grows so slowly the first year that the young plants are in danger of being smothered out. By sowing turnips or other quick growplants in the same drill the rows can be cultivated before the Lathyrus plants are out of the ground, which lessens the labor of cultivation. After the first year the plants will take care of themselves, and will take full posession of the land, throwing out runners and covering the ground, then sending up perpendicular shoots two or three feet high and very thick and dense. The leaves are about three-eighths of an inch wide, two to four inches long, and with the suculent stems form a very sweet and palatable food for stock, of which all kinds readily eat. Once established, Lathyrus will stand $\mathbf{5 0}$ years if desired, with. out re-seeding, and will constantly add to the richness of the soil. Its fertilizing power is well illustrated by a field of it growing in Germany on the rub. bish of an old coal mine, where it has grown luxuriantly for the last 13 years. The plants may be transplanted either in spring or fall on any kind of soil, even on rocky ground, but not on wet lands.

That this plant is well adapted to America is established by the testimony of Pres. O. Clute, of the Michigan Agricultural College, who writes:

JULY, 1893.-Those who have walked through the station fields since the first of June, cannot fail to have noted the very luxuriant and beautiful plat of more than an acre in extent of the new forage plant (Lathyrus Silvestris). It started early in the spring, every root having endured the severe cold of winter without injury. The tops were uninjured last fall by severe frosts. They did not stop growing until heavy freezes came. Indeed, where there was quite a covering of tops and the snow fell early and remained on the ground, those sprouts on the under side at the surface of the ground were not killed by the freezing of winter, but remained green until the plants began'their new growth this spring. The whole field started early and made a green and beautiful appearance. Then came on a long spell of cold and windy weather, which kept everything back, hence it was not until late that the plants got down to work. Since then it has let itself loose, so to say, and grown in a reckless but determined fashion. Every root sent out numerous shoots that spread away on every side until the ground was covered with a dense mass. Then it began to climb up. The tendrils of one shoot caught on to all the neighboring shoots, and by June there was a deep garment of verdure more than three feet in depth, which yielded at the rate of sixteen tons of green forage per acre. Cured it made at the rate of four tons of choice hay per acre. The forage is eaten eagerly by all kinds of farm stock. Not only does it enrich the soil, but it is able to flourish on very poor soil. Our flat peas were sown on the most sandy soil of our farm. When one sees the
freshly dug plant, with its hundreds of tubercules, he feels sure that if any plant can enrich the soil this one can. Price of seed, large packet, $25 \mathrm{cts}$; ; ounce, $50 \mathrm{cts.;} 1 / 4$ pound, $\$ 1.50 ; 1 / 2$ pound, $\$ 2.50$; pound, $\$ 4.75$, postpaid. (STOCK LIMITED.) 
CHIS is a page of FOFA GI PI A ITTS. Stock relish a change of food as much as do human beings, and a good appetite results in better growth. Devote a small piece of ground to some of these FORAGE PLANTS. Excellent either for green or dry feed. All of them have been PROVEN GOOD. An experiment will demonstrate which is best for any particular soil and climate.

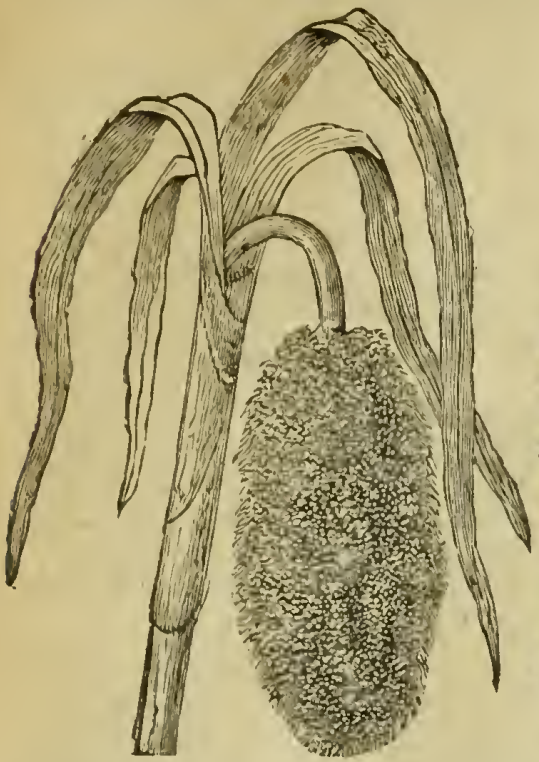

BROWN DHOURA CORN, Has yielded two hundred bushels of clean grain per acre. Thls vartety is highly valued beon poor, dry soll. 'The grain is superior food for fowls, and as good as wheat or barley for horses. As forage, the stalks are eaten greedily by cows and sheep. lb., 20 cts.; 100 lbs., $\$ 6.50$.

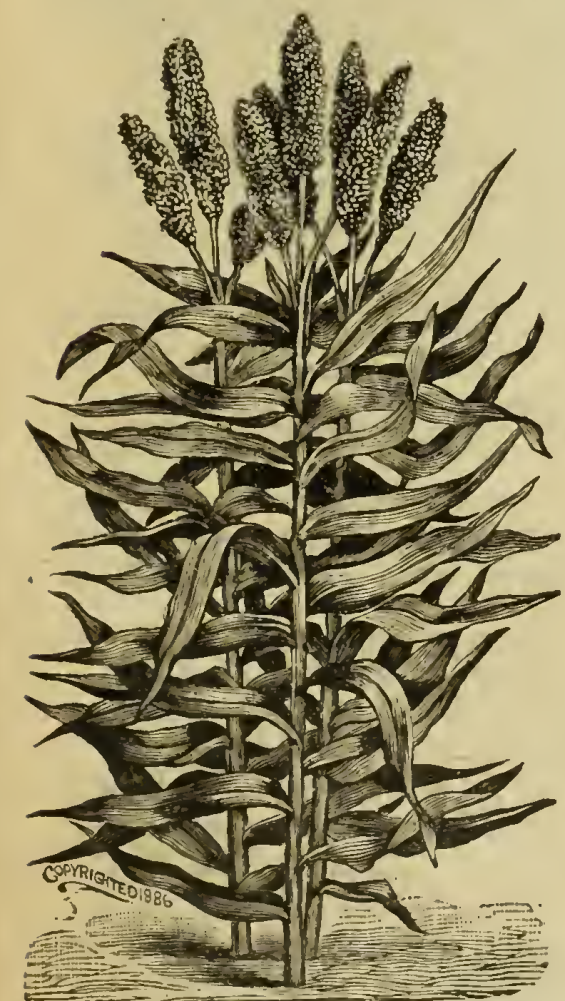

KAFFIR CORN. For a torage plant it is destined to become a valuable acqulsition in all sections of the country adapted to dry stufif, for the grain and forage. On very thin dry seasons ln which common Indian corn has utterly falled on the same lands. The whole fodder, and ln all stares.

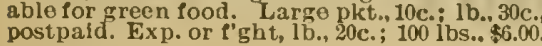

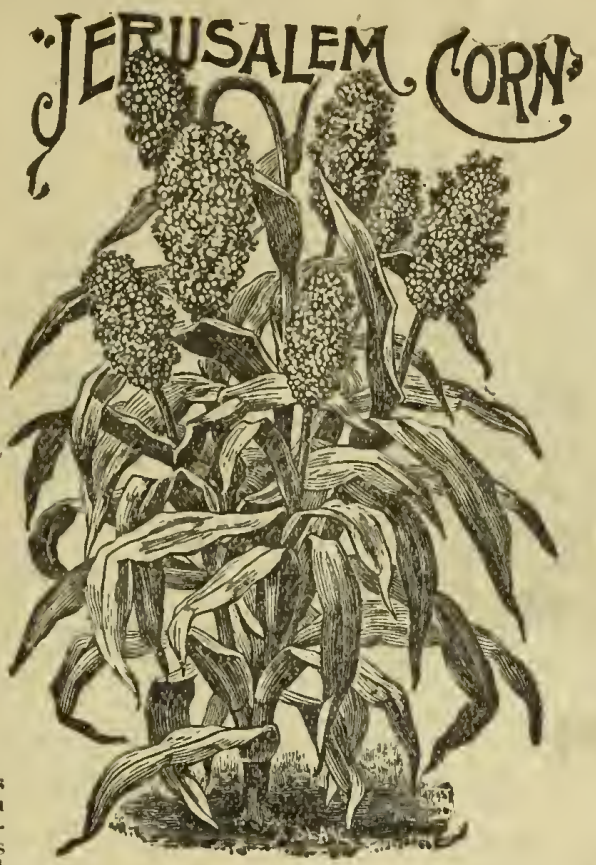

A NEW FORAGE PLANT.

The Jerusalem Corn belongs to the nonsaccharine sorghums. It grows about three
feet high, makes one large head on main feet high, makes one large head on main shoots, often as many as eight heads on one flat, three pounds of pure white and nearly plant an acre. Claimed to be one of the best seasons. Large pkt., $10 \mathrm{cts}$. $; 1 \mathrm{~b}, 30 \mathrm{cts}$., postpald. By express or freight, $100 \mathrm{lbs}$., $\$ 6,00$.

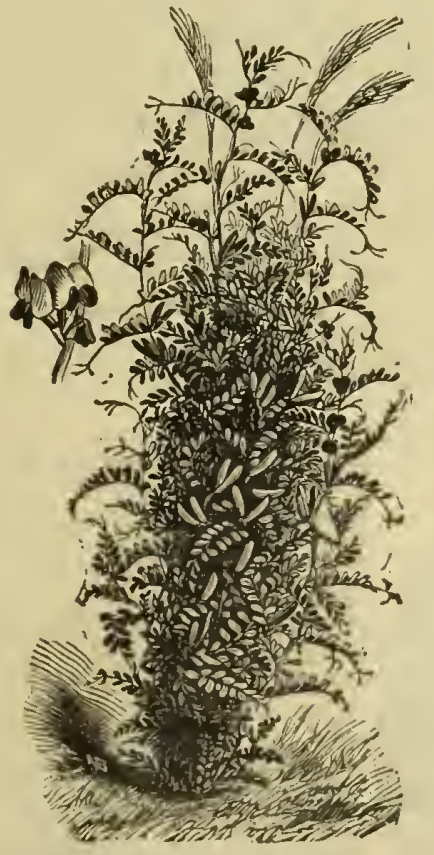

VETCHES. For Spring or Fall Sowing. Vetches are grown for a forage crop. They can be cheaply raised, red green, cured or engrown largely for this purpose, and. where pasturage is poor or costly, it wlll pay to or freight, peck, $\$ 1.00$; bushel, $\$ 3.25$.

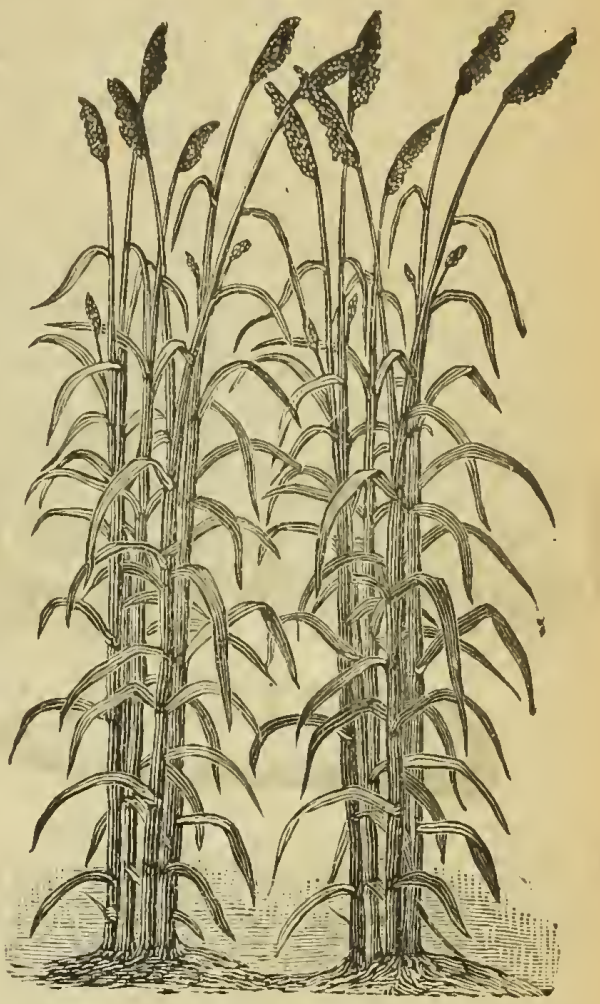

Improved Minnesota Early Amber Sugar Cane. Get pure seerl of the Improved Minnesota Early Amber. When planted between the first ripens, yielding 20 to 25 bushels of seed and 140 o 240 galons of syrup per acre. Its earlines adapts it to almost every section, having been minutes, and has given entire satisfaction Wherever lntroduced. Large pkt., $10 \mathrm{cts}$.; lb.. 2 cts., postpald. By express or reipht, 5 lbs. 1 KANSAS GROWN AMBER CANE. TWo to three pounds of seed reguired per acre. 5 lbs. (a) 8 cts.; 20 lbs. @6 cts.; 100 lbs. (6) 4 cts.

ORANGE CANE. A popular sort, excellent or sugar or lodder. Lb., 20 cts., postpaid. By express or freight, 5 lbs.@8cts.; 20 lbs.@6 cts.;

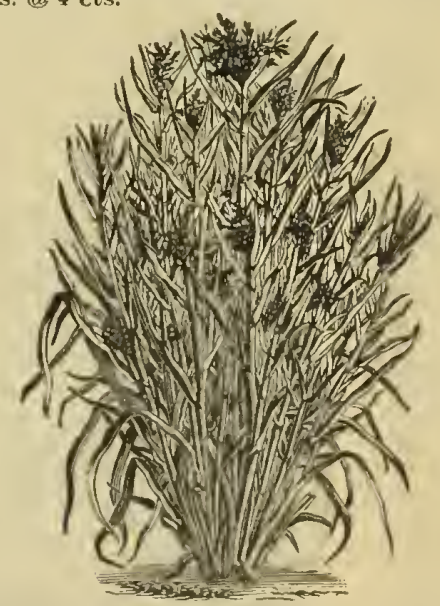

TEOSINTE. (Reana Luxurians.) A forage Ther the South western and Southern states. ith leaves, sielding such an abundance of forage that one piant is considered to be sufficient Not recommended for the Northwest. Price of eed, pkt., $10 \mathrm{cts.;} 07 . ., 25$ cts.; 1b., $\$ 3.00$, postpald. 

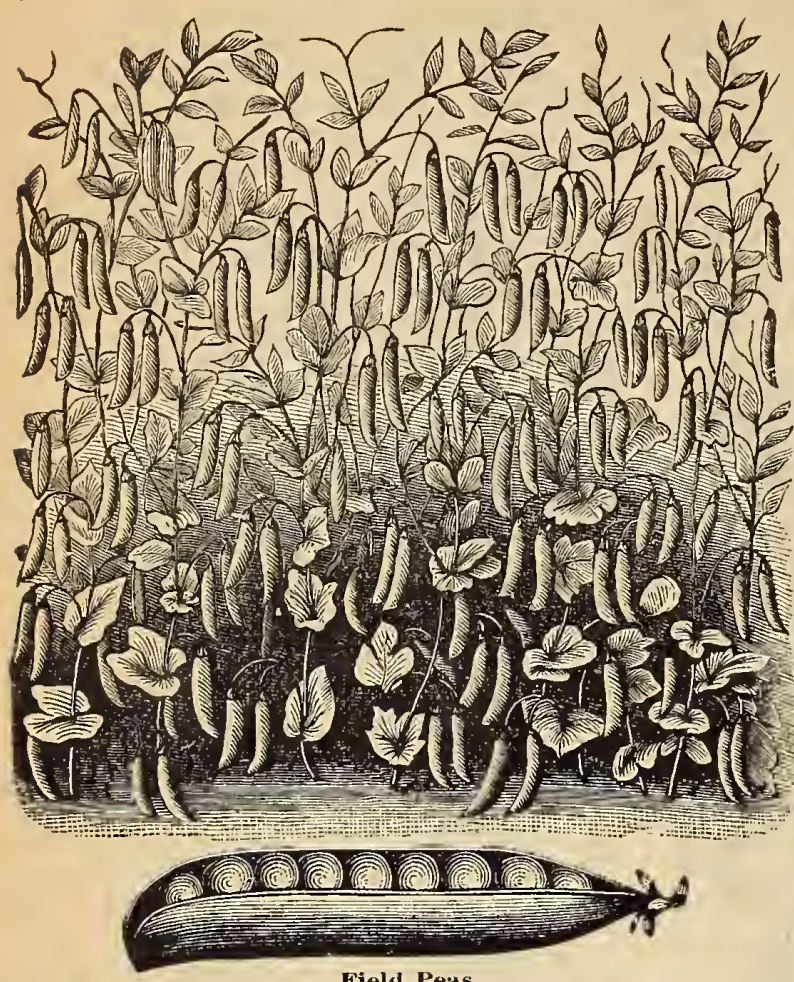

Field Peas.

FIELD PEAS. This crop should be grown much more largely than it now is all over the United States and especially throughout the Northwest. It is a PAYING crop in many Directions. ist. Peas CAN BE GROWN IN ALMOST ANY to grow, in that the peas when threshed are as STAPLE AS WHEAT and can always be marketed. 3d. They stand in the FRONT RANK as a FODDER PLANT being very rich in the elements that improve the muscle, bone and nervous system. 4th. As much of the crop as may be desired can be fed green, the balance may be used as dry feed or the peas can be threshed and sold, last but equally, perhaps MORE IMPORTANT STILL, AS A KENOVATOR OF THE SOIL THEY RANK NEXT TU CI.OVER and can be readily grown where clover will not thrive. Their MANURIAL $\nabla \triangle L O E$ is a point that should not be lost sight of, particularly by thosewho have grown wheat year after year and upon ground no longer producing large crops. The reason is plain. The nitrogen is exhausted from the soil. Peas are great absorbers of Nitrogen from the atmosphere and land upon which they are allowed to grow and the crop plowed under will the next year show plainly the great benefit; even if the crop is harvested and the stubble only turned under, the improvement will be very marked. Farmer 列

FIELD PEAS can be sown alone or with Oats. If alone, about 3 bushels are required to the acre. If with oats, $1 \frac{1}{2}$ bushels of Peas and 2 bushels of oats. The lat ter is a favorite and profitable method, and one that we strongly endorse, as in this way a double crop can be secured. They can be threshed at one time, and readily separated in cleaning. Do not sow Peas on too rich ground, as they run to vine instead of pod.

N. B. G. CO.'S CHANCELLOR FIELD PEA. white. Height of vine $31 / 2$ to $4 \mathrm{ft}$. We wish to cal especial atteation to this Pea as being ${ }^{2}$ portant considcration, not only with peas, but with other farm crops, providing that the yield of the early sort chosen is as great as the late, for it is a self evident fact that the risk is decreased by as much as the growing can be reduced. The pea in question is not only earlier, but we beleve, more productive than any of hnr sort. Quart. 35 cts., postpaid. By

CANADA FIELD PEAS. White. Height of vine $3 \frac{1}{2}$ to $4 \mathrm{ft}$. This is

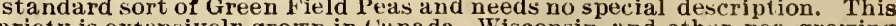
ariety is extensively grown in C'anada, Wisconsin and other pea growing use in soups. Qunrt $30 \mathrm{cts}$. post paid. By express or freight, quart, 15 cts.; CANADA FIELD PEAS. Green. Height of vlne $3 \frac{1}{2}$ to $4 \mathrm{mt}$. Of the

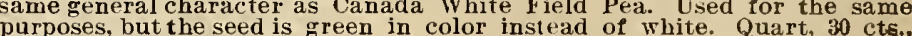
purposes, but the seed is green in color instead of white. Quart, 30 cts., postpald. By express or treight, quart, 15 cts.; peck,

Thertion of withered or shrunken kernels, causing considerable loss when it is giound or niarketed. The Amber Rye to which our attention was called by a Minnesota farmer this characteristic, which saves easlly from two to five pounds to the bushel, but that whenever it has been sown it has invariably and large-

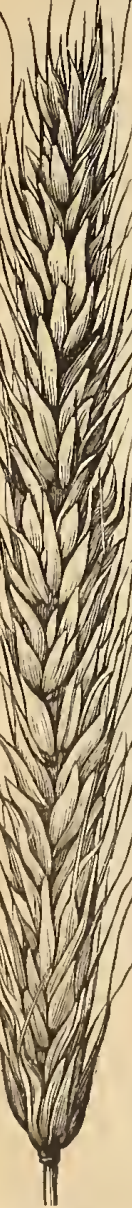
grown grain. Rye growers should seize this oppoltunity to secure this improved stock at the very reasonable price we attach. paid for itself several times over. Peck $50 \mathrm{cts}$.; bush., $\$ 1.45$; 2 bush., 52.75 ; 10 bush., $\$ 11.00$. Bags included.

WINTER RYE

SPRING RYE.

Peck, is cts. ; bush. $\$ 1.25 ; 2$ bush., $\$ 2.10$; 10 bush. $\$ 9.00$.

Peck, 40 cts.; bushel, $\$ 1.40 ; 2$ bushel, $\$ 2 . \% ; 10$ bushel $\$ 11.00$

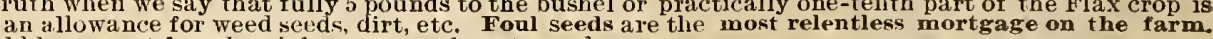

NEW BELGIAN. Peck 50 cts; bushel, 2.00 ; 2 bushels, 3.50 Bags included

IMPROVED RUSSIAN.

JAPANESE BUCKWHEAT. Entirely distinct from all other varieties, the kernels a re at least double the size of does not need to be sown as thickly as the other kinds. On account of its earliness it can be grown further north than any SILVER-HULL BUCKWHEAT. This vauable variety originated abroad, and is a decided improvement on the continues longer in bloom and yields double the quantity. Makes the finest flour. Large pkt., $10 \mathrm{cts}$.; 1 b., 25 cts., postpaid. COMMON BUCKWHEAT. Selected. By express or freight, bushel, \$1.00. Write for special prices on large lots. NEW EVERGREEN BROOM CORN. The best variety for general cultivation on account of color and quality a most desirable point to broom corn raisers and manutacturers. Large pkt., $10 \mathrm{cts}$; ; 1b., 25 cts., postpaid. By express or NEW JAPANESE BROOM CORN

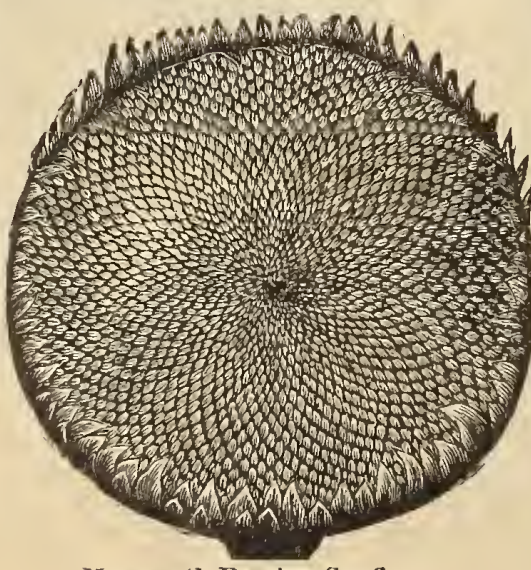
planted late, has been planted on July 17 and ready to cut 0 ct. 1 . luarge pkt., MAMMOTH RUSSIAN SUNFLOWER. Single heads measure rom 12 to 2 inches in diameter, and contain an immense quantity of feed, which is highly valued by all farmers and poultry breeders who have tried lt,

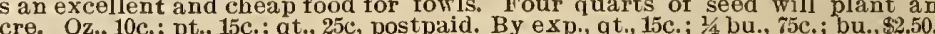
IVERSONS IMPROVED PEANUT. A new kind, combines earliness,

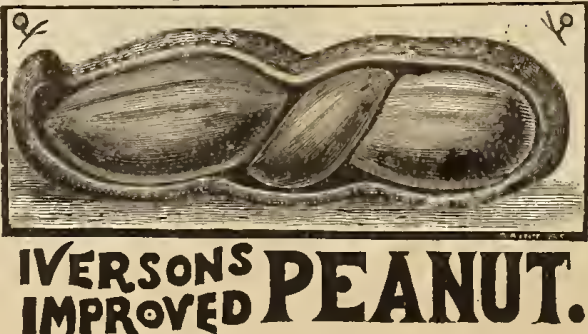
valuable forage for stock. SPANISH PEANUT. The Spanish Peanut is the earliest variety grown; pods and altogether consldered of superior quality. For an nothing better, although the Iverson's Improved are more prolific, while the Spanish are easiest to gath-

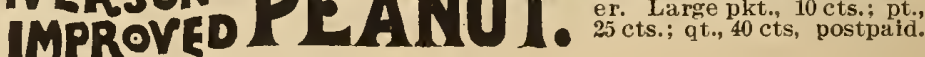


The statements we have made about the advantages to be gained in using NORTHERN GROWN SEED of OATS, CORN, etc., apply with equal force to POTATOES. The importance, and in very many sections the ab= solute necessity of using northern grown stocks is so generally recognized by all intelligent planters that to dilate on the subject would be about as profitable as to argue that 2 and 2 make 4 . It will be observed that we list but a few varieties, and to these we wish to draw the special attention of our customers, as being varieties that are calculated to fill every requirement for early, smooth, productive, healthy, good eating, good keeping sorts. We can usually supply any variety wanted and will at all times be glad to quote them.

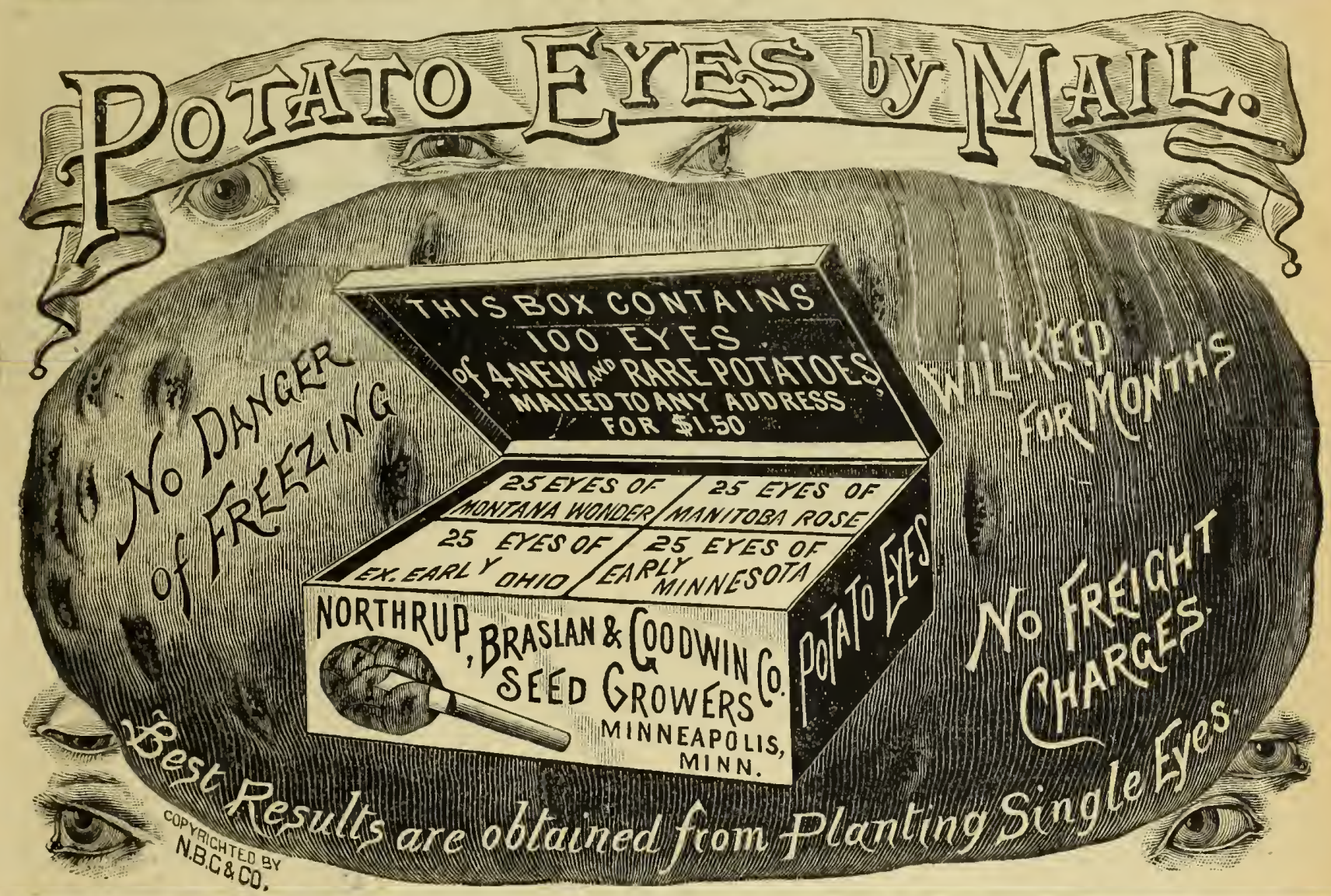

POTATO COLLECTION. This splendid collection consists of 25 eyes each of EARLY MINNEOHIO, and will be sent by mail to any address on recelpt of \$1.50. Safe Arrival in Good Condlton for Growing is GUARANTEED. Thls offer should attract the favorable attention of all who wish a START on good varleties.

POTATO EYES. We believe that we are the originators of the system of sending potato eyes by mail.

First - It has been conclusively proven that potatoes cut to single eyes give the largest yields and best results generally.

Second - No freight charges to pay.

Third-They can be sent without danger af treezing. A customer can secure them in ample time for planting without incurring this risk.

Fourth - By our improved method of preparing the eyes for solpment, they will keep in good condition for months.

POTATO SEED. A very interesting employment is that of growing new sorts of Potatoes from the seed. A small package of the true hybridized seed will produce a number of seedlings differing diameter the fist cor nother gencral characteristics. The tubers rarely grow to be more than half an inch in that their comparative worth ean be truly determined. At that time it will be strange indeed if among them is not found at least one or two thilt will well reward all the effort that his been expended on them. In this way have been obtained our choicest and rarest varietics. The seed should be planted in fairly rich soil about corn planting time. Keep clear of weeds and give good cultivation. Pkt., 20 cts.

PETER ETTER, Jr., Oidenburg, Ind., writes: "Am well satisfied with Potatoes you sent 3 years ago. Sold them for $\$ 3$ per bushel this year." GEO. M. PIERCE, West Baden, ind., writes: "The Seeds 1 got of you before did well and proved truo to description. therefore 1 send again." 


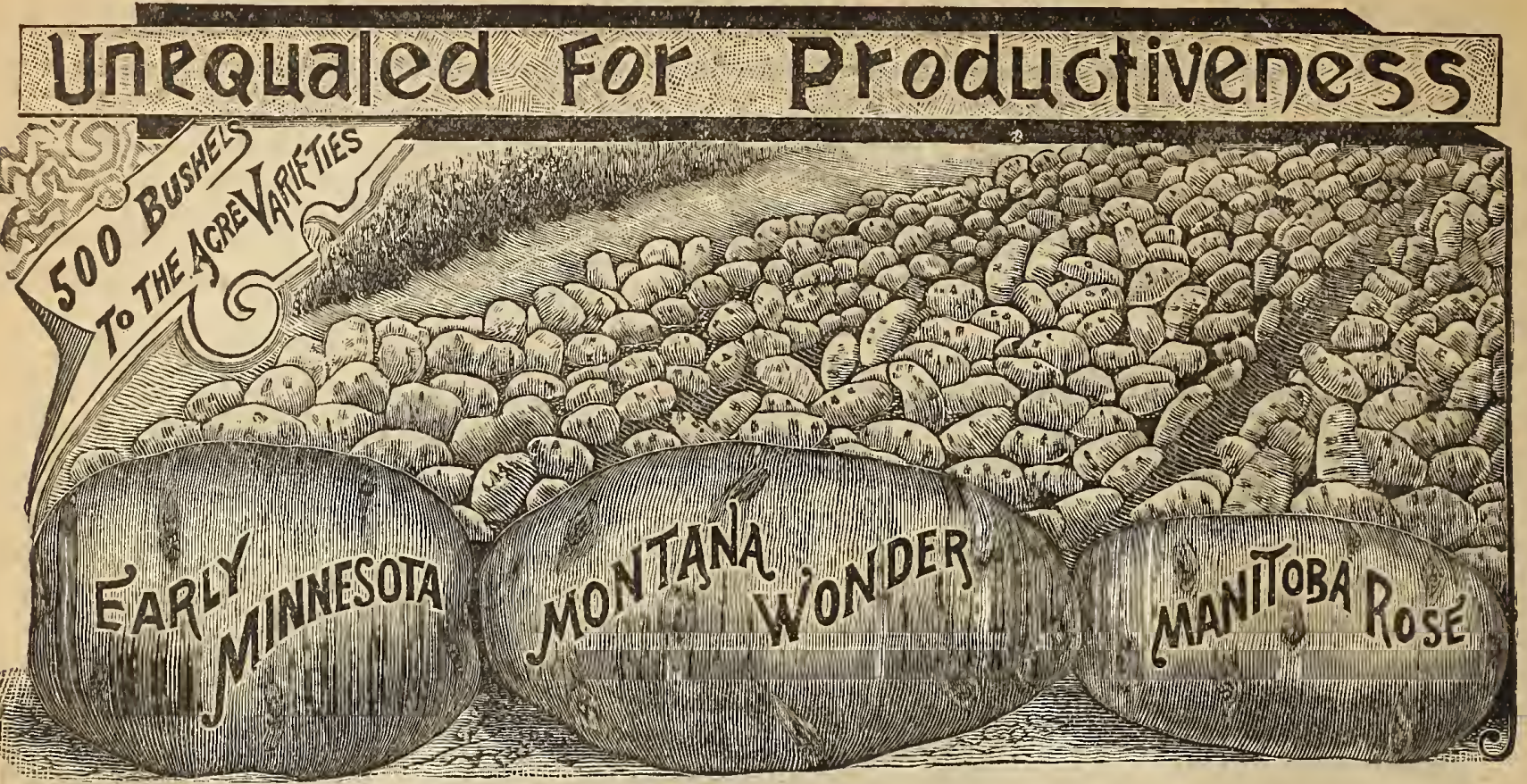

The remark of the toper who said that "all whiskey was good, but that some kinds were better than others," could be applied with a good deal more truth to Potatoes. All purchasers should be able to make a selection from the list we catalogue. All are good. The three varieties shown in the engraving are certainly calculated to satisfy those who want Early, Sound Potatoes, free from Disease, and possessing in the highest degree that vigor peculiar to potatoes grown in the Far North.

EARLY MINNESOTA, very early. The distinguishing characteristics of this potato, aside from its productiveness, are qualities. The flesh is of peculiar purity, and when boiled is almost as white as milk, As a baking sort it has no superior, if any we cail attention, viz: uniformity in size is growers, as a great difference exists in this particular among the various sorts. 100 eyes, $\$ 1.50$, postpaid, By exp. or
$50 \mathrm{c} ;$ bu., $\$ 1.50$; bbl, of 165 lbs., $\$ 3.75$.
MONTANA WONDER. Early, Large in size. Wonderfully productive. Those appreciate the beauty and solidity of this mon quality. Originally the Montana Wonder Their increase in this particular is no doubt due to their having been grown where they by neans of irrigation. The most critical could not ask for a better potato 100 eyes. 1.50, postpaid. By exp. or frt., peck, 50c;
MANITOBA ROSE. Extra oarly. Several years ago we bought several car toes, out of wlich we fild our orders for Early Rose. These brought us so niany expressions of satisfaction that we were induced to again offer thens. They are the finest, earliest and healthiest stock of Early Rose Potatoes extant, surpassing in ever respect the Maine grown Early Rose, wbich enjoyed such a wide reputation. This is strong praise, for the Farly kose in 1 th urpaid. By exp. or frt., peck, 50c; bu., \$1.50;

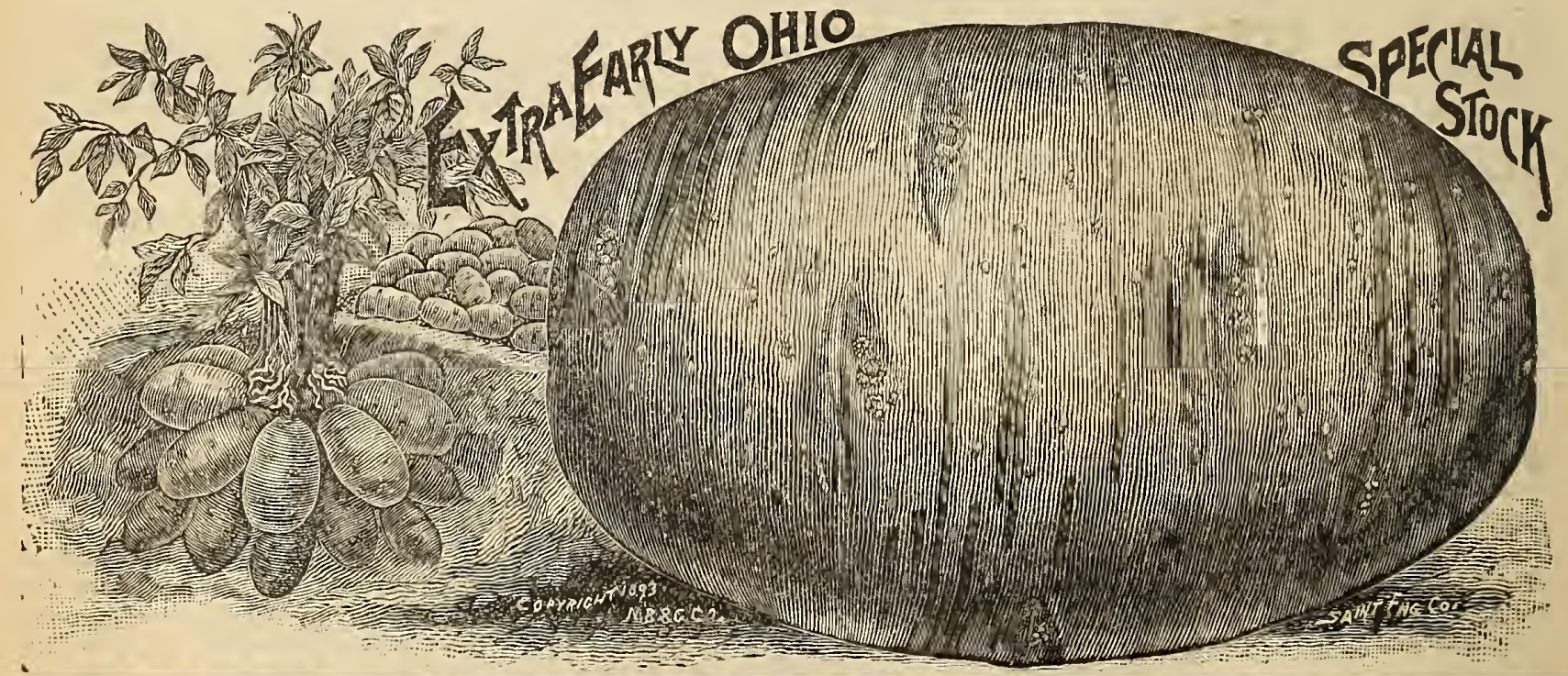

EXTRA EARLY OHIO. Last year we were able for the first time tc offer this special stock of Extra Early Ohio potatoes. Every one who secured them was delighted. Unfortunately we had but 400 bushels, and as they went like "hot calies," we could not fill but a small proportion of the orders we received. We have again had them glown in North Dakota, and although our stock is sonewhat larger than ohio Potatoes in existence should place their orders early. They will not be whipped until danger of frost is past. By express or freight,

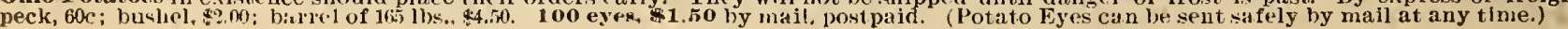




\section{GRASS SEED MIXTURES.}

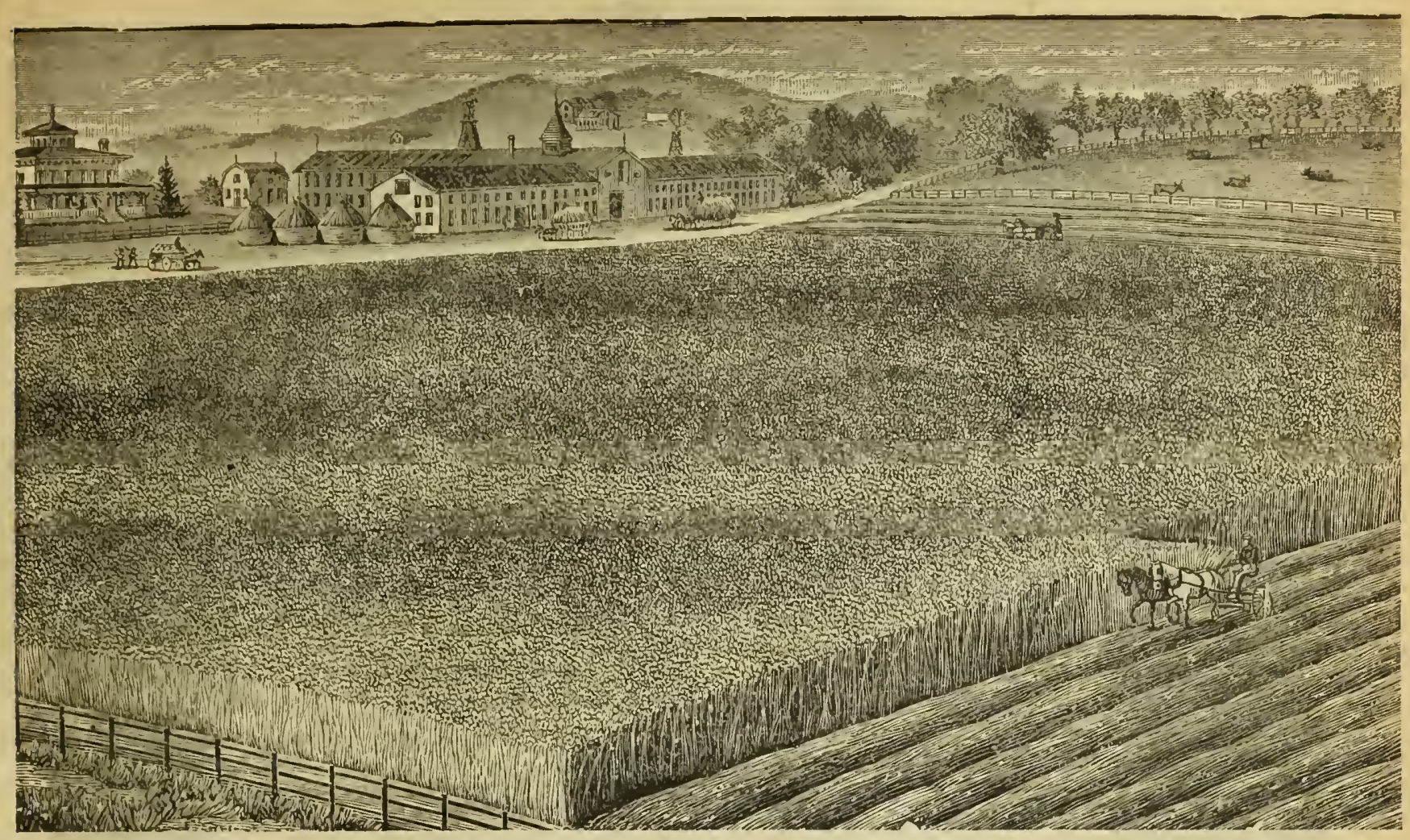

All authorities agree that for Pasture and Hay, best results are obtained from the use of grass seeds in mixture. The reasons are obvious. First-A number of species will insure a much denser growth than the same number of seeds of one or two species, and prove less exhausting to the soil, since they live to a large extent on different constituents. Second - Seasons that affect some grasses adversely are favorable to other sorts, so that with mixtures a failure is practically impossible, provided, of course, the seed is good. We take great pains in selecting grass seeds in order to secure the lighest germination, and mixtures are based on a full appreciation of the requirements of different soils for which they are intended.

N. B. G. CO.'S ROYAL GRASS MIXTURES. We ask purchasers to oherve the basis on which our prices on the following mixt tires are mades lirst. That the prices are vot for a bushiel, but on xufficient quantity for one acre. Siccond-That no ehanges can be made in these mixturets. We are able to offer at these very low figures only from the fact that we inalse up large quantities before the commencement of the seasoll, therefore notling call be taken out. We cannot afforld to add anything to the mixtures on account of the slight margin upon which we have figured. We shall be happy. however, to nake estilmates on any specilut mixtures desired by our patrons. Our price for an acre lo fixd on the lasis of a yood, fair seeding. The guantity can of course, be spread over more or less ground as the case may demand. It will bre noted thlat the cost for poor soils exceeds that for better land, as a larger cuantity of some of the more expensive grasses is necepsary in order to secure best results. N. B. G CO.'S ROYAL MIXTURES FOR PERMANENT PASTURES, These mixtures are made up for Light, Meblossow at dirferent perlodl.

Neadow Foxtall, flowering in May and June. Red Top, flowering in June and July. sweet Vernal true perennial i llowering in

A pril and Miry.

Timothy, flowering in June and July.

Kentucky Blue Grass, llowerinot in Mitiy and

Red Top, flowering in June and July.
Perennial Rye Glass, flowering in Iune.

Orchard Grass, flowering in Mlay and June.

Rhode Island Bent, flowering in Julle and

July.

Englisla Rye Grass, flowering in June and Mammoth or Perennial Clover, tlowering in June.

Such a combination insmres good focd, and a luxuliaut growli during the entire saason.

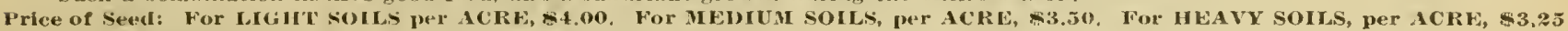
N. B. G. CO.'S ROYAL MIXTURES FOR HAY. These mixtures are finfinitely supertor to the ordinary mixtures of Tim-

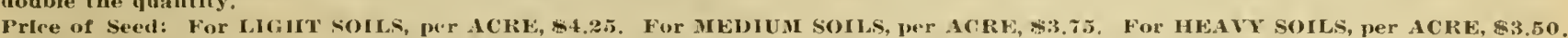

\section{N. B. G. CO.'S ROYAL MIXTURES FOR ORCHARDS AND SHADED PLACES.}

$$
\text { Por I'ASTUKE, per ACRE, \$4.00. For IIAY, per ACRW, \$4.25. }
$$

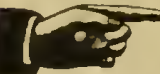

We ask our customers to particularly notice the very low prices we make on these mlxtures. They include bags and delivery on board cars. We will allow a discount of 5 per cent for five acre quantities. Write for best possible discount on larger quantities.

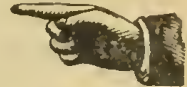

CHAS. WILEK, Sherwood, Mlich, writes: Last spring I sowed one bushel of LINCOLN OATS in weight, or three pecks in roeasure, on three-quarters of an acre of ground. We had a late, backward spring, wet at that, followed by extreme heat and drought. Nevertheless, I ralsed 30 bushels, machine measure, weighing out 36 bushels 18 pounds of the finest oats I ever raised. With a favorable season, I could have beaten thls one-half. I think the LINCOLN OATS are at the head of all other varieties.

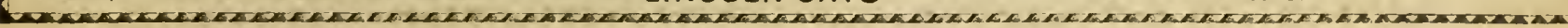


Owing to constant fluctuation in values of Grass Seeds, Clovers, Millets, Tree Seeds, etc., we are obliged to make the prices subject to mar= ket changes.

Write for samples and special prices.

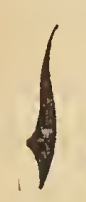

\section{ce} a $\operatorname{sics}$

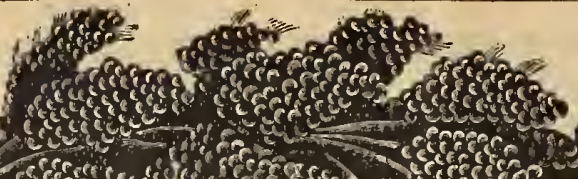
-

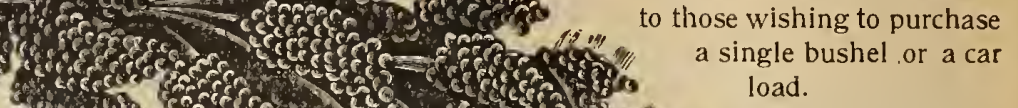
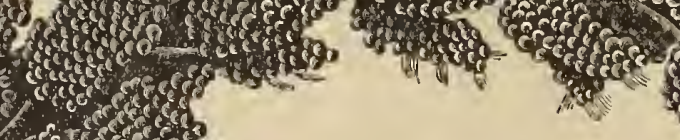

N. B. G. CO'S.

\section{GOLDEN WONDER MILLET.}

\section{Introduced by us in $\mathbf{1 8 8 8}$.}

Each Year Increases its Popularity.

We are always glad to send samples of Grass seeds, etc., free of charge and to make special quotations
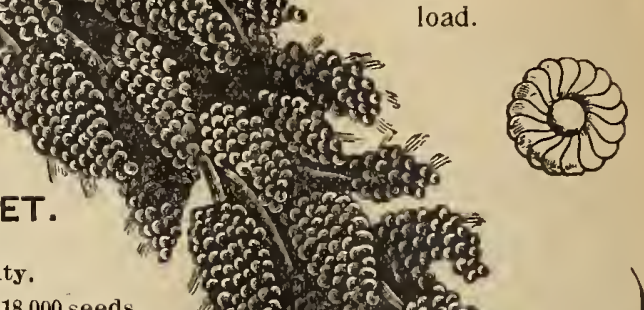

Heads eighteen inches $\ln l 9 n g$ th containing 18.000 seeds are not rare. The a verage length of head is about fifteen about one-fourth of an inch, full of broad leaves, resembling those of corn, yielding ten to twelve tons of fodder per acre. which is as easily cured as clover hay A splendid ensiluge plant the same as other millets-the advantage being that it will yield. under equil circumstances three tinies as much seed and twice as much fodder per acre. "Golden Wonder willet" tured in high lutitudes, where corn will not ripen. It should be sown or planted about June 1 st, and will then do to harvest after the wheat crop has been secured. To get the best results for fodder, sow on rich ground aud cut before the seed is ripe. One of the best crops known for cutting and feedlng green, since its yield is large, its leaves juicy and tender, and much relished by milch cows and other stock, making a palatable change from hay. No better food can be found for poultry and swine, but lt is not equally well regarded as food for horses, but like fax, fed in moderate quantities, gives good results. Ground and fed to stock lt is par excellence. Pkt., $10 \mathrm{cts}$.; $3 / 21 \mathrm{lb}$., $15 \mathrm{cts}$.; $1 \mathrm{~b}$., 40 cts.; postpaid. By express or frelght, peck, $\$ 1.50$; bushel, $\$ 4.00$.

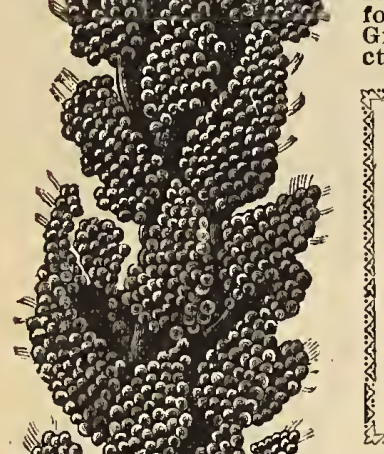
siseng

\section{— MILLET SEEDS. -}

7 HOSE who read our Catalogue will see that we believe that 4 Northern Grown Seeds are the Best. An exception, how. ever, to this rule, is Millet, where it is to be grown for Hay. Southern Grown seed is better for this purpose than Minnesota or Dakota grown, as it is more rank in growth, and consequently gives more tonnage to the acre.

Prices Include Bags. Add $10 \mathrm{cts}$. per $\mathrm{lb}$. if wanted by mall.

MILLET, German, Southern grown (50 lbs. bu.)........ bu. $\$ 1.10 \quad 1001 \mathrm{bs} . \$ 2.20$ Gelman, Dakota, glown, Common, Dakota grown, Hommon, D

bu. 900000

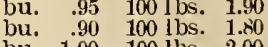

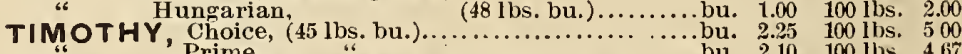

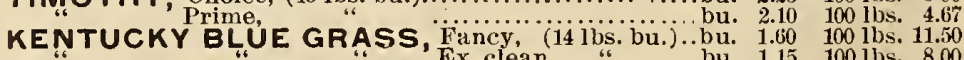

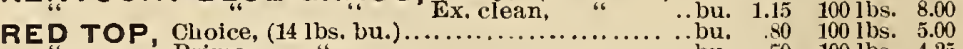

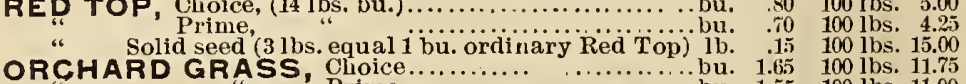
OR.

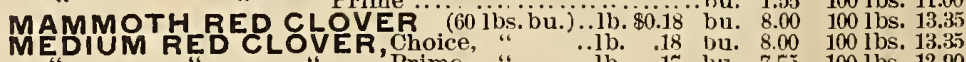

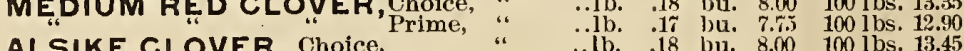

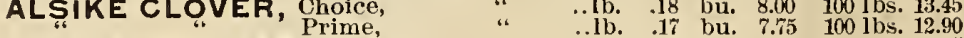
ALFALFA CLỌVER, Choice, WH!TE CLOVER, Choice, SCARLET CLOVER, lib. .17 bu. 7.75 100 lbs. 12.90 lb. .16 bu. 8.25 100 lbs. 13.15 lb. .25 bu. 11.50 100 lbs. 19.20 lb, .20 bu. 11.00 100 ]3s. 18.35

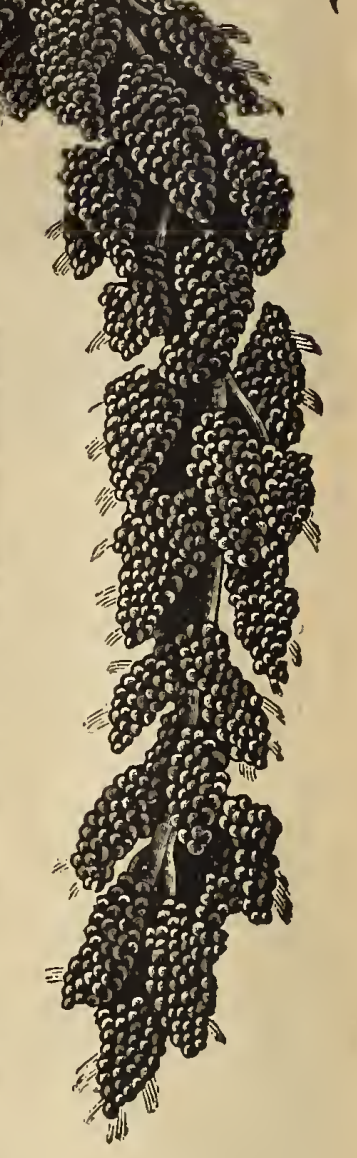

\section{IMPORTED AND FANCY GRASSES.}

Add ro cts, Ib. if Wanted by Mail.

CRESTED DOG'S TAIL. Used only in small quantity, for perREsture mixture.

CREEPING BENT GRASS. Succeeds well in moist meadows. ITAL-IAN RYE GRASS. Succeeds well ou moist and fertile
soils. Lb. 15 cents. PERENNIAL RYE GRASS, OI ENGLISH BLUE GRASS MEADOW FESCUE. An excellent pasture grass. It should be sown in mixture with other grasses. Lb., 20 cents.

TALL FESCUE, Grows naturally in shady places and moist soll, cattle are very fond of it. Lb., 30 cents.

HARD FESCUE. Lb., 25 cents.

SHEEP FESCUE. Excellent for dry soils as sheep pustureage. Lib., 25 cents.

RHODE ISLAND BENT. Lb., 25 cents; bushel, $\$ 2.50$.
Write for Prices on Larger Quantities.

TALL MEADOW OAT GRASS. A permanent pasture grass YELLOW OAT GRASS. Suitable for dry soils. succeeds best when sown with other grasses. Lb. äs cents.

MEADOW FOX TAIL. Valuable on account of its early and rapid growth. An excellent permanent pasture grass. Lb., 40 cents. FOWL MEADOW. Sultable for low, moist land. Excellent for cattle and sheep. Lb., 25 cents; bushel, $\$ 2.50$.

WATER MEADOW GRASS. Lb., 50 cent.

WOOD MEADOW GRASS. A good pasture grass for molst ROUGH STALKED MEADOW GRASS, Succeds well th moist, sheltered soils, and is relished by both cattle and horses. Lb., 45 cents.

DWARF WOOD GRASS. Lb., 45 cents.

SWEET VERNAL GRASS. Lb., 25 cants. 
LAWN GRASS, - How to make New Lawns. How to repair Old Lawns. How to keep Lawns Green, Etc.

(

BOSTON

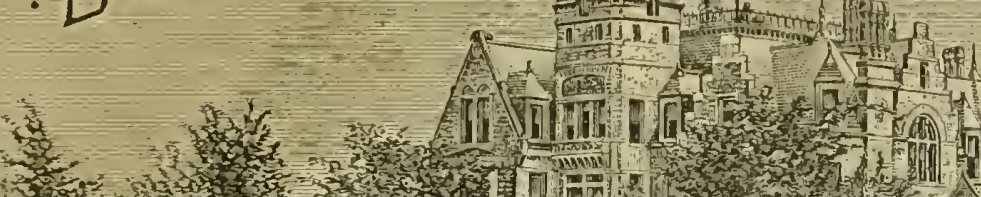

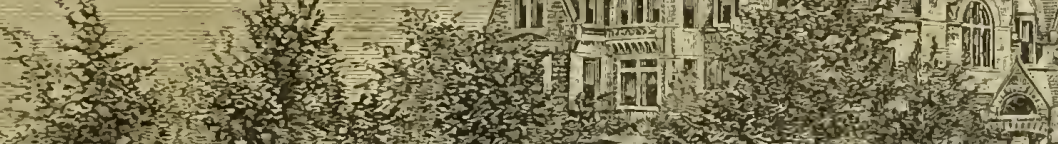

- $\mathrm{N} N \mathrm{~N}$

$6 \mathrm{~A} \rightarrow{ }^{\circ}$

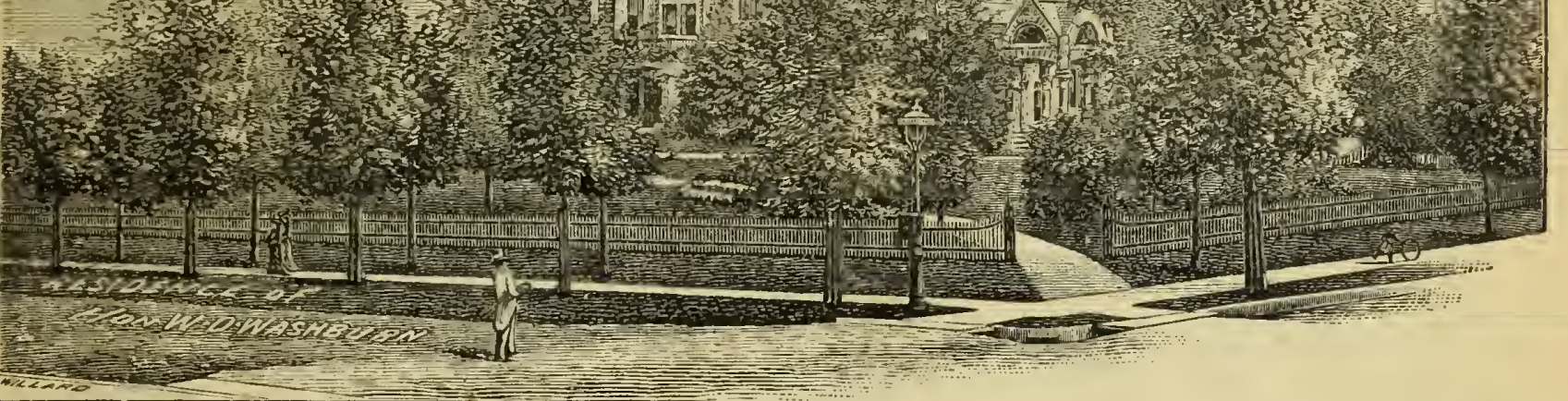

A BEAUTIFUL LAWN. No feature surroinding a home is of more importance than the taun. A beautiful lawn is so generally desired that and of the urticles in which we ace interested, but will bring relief and satisfaction to the thousands who have strinen, yet failed, lo secure proper returns.

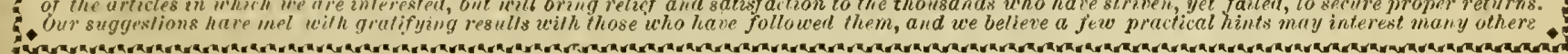

NEW LA WNS. HOW TO BULD THE.I.-After the Iawn is graded the first thing is to give the entire surface a thick coating of hlack earth. This is a prine r+quisite and should be done in all cares, where possible. A tuilding cannot stand, without a proper foundation; neither can a lawi. If the ground is sloping. $\Omega$ thicker dressiug is uecessary than where the ground is level, as heavy rains oftentimes will wish the top soil away, especially before the lawn lias per the surfnce should be made perfectly level. After this is done the seed may he sown, from four to eight binhels of seed sould he sown in one direction. After this is done, sow the other half at right ningles. In this way a more even distribution of the seed is ohtained, especially hy those not in the hubit of sowing grass peed. The seed should he sown hroadcast by hilld. After thus applying, rake the lawn over well, smoothing any inequalities of surfuce. Go over it then with a roller, if one can be obtained. This presses the seed into the ground at a nniform depth, and adds to the moothness of the lawn. If a garden roller is not easily ohtainahle and the lawn is not too large, press it down with a wide hoard, the ohject in all cases heing to mike the rurfaco us smooth as possible. Water shonld be used freely on lawns. Constaut watering gives that healthy appearance eo greatly adinired. After a lawn is in good condition, the grass should he cut every week or ten days during the geason. NoT ers have heen rimning a mower oser their lawn within six weeks after the seed was sown, the lawn showing every appearance of heing several years old. Ter carected, rake it over early in the sprinu with a short-toothed steel rake in order to clean off the dead leaves and twigs. Then spread over it a thin coating of rich loam flling np the low places and making the surface even. If it is very much below orade, the old turf may be removed and the low space filled np with loam, then replacing the turf and pntting g light coating of loam over it. We say, this may be done. It will answer well if the turf is of

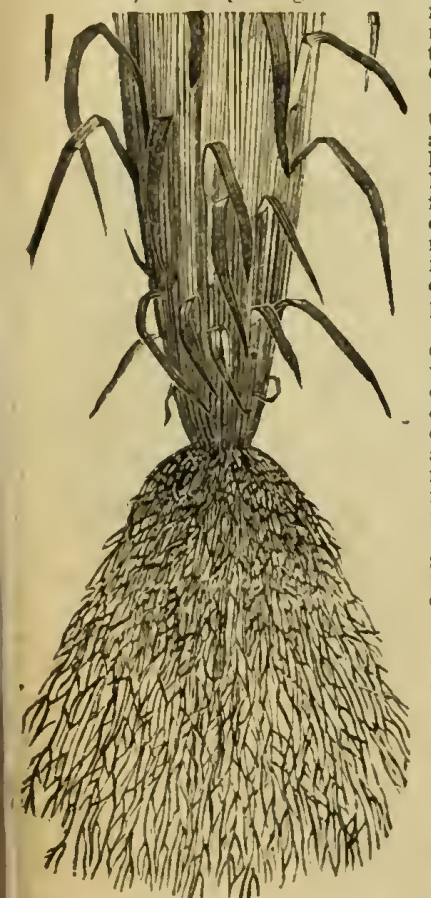

Root of Plant Showing the Effect of
Liging Excelsior Lawn Dresing. fine quality, hut if the grase is thin and turf poor, we would by all means recommend filling np the ground to the desired level and proceed as with a rew lawn, sowing the seed and ignoring Grass Seed liberally over the surface at the rate of one guart to every throe luandred square feet. HOW TO KEEP A LAWN GREEN, Lawn Grake is a voracions feeder and will not thrive and hold its color unlese it receives a sufficient supply of suitable food. The reason there awn is always " velve "lawn. There are two methods from which to choose hy which the lawn can be thus fed: First, by the nse of stable nanures; second, hy the nse or commercial ons. It cannot he eveuly distributed, the result heing that one spot is over-nourished, while the next is starved. There will alno come up a plentiful crop of weeds from weed seed contained in in: plant foods in the forms and proportions to suit the purposes for which they are intended. LA WN GRASS SEED.-We prepare three grades of Lawn Grass Seed, which are kept constantly in stock. The hest of these nixtures is the N., B. S G. Co.'s Boston Lawn Grass, which has heen uxed with the greatert success on thousands of lawns. This mixture is composed of a number of varieties hest adapted to the puipose. Some of the grasses are early, others mewhers are ready to take its place. Another important point is that hy the use of many grasses, a much heavier sward is ohtained than is possible with any two or three sorts. For example, no matter how much of one kind of seed may be sown on a given space, it will only support so many plauta. If another variety, however, is sown in connection with it, a largely additional number of plants can he maintained, as they thrive on different elements in the soil. In this as in other mixtures, we endeavor to enpply only the very highest quality of grusses, both as to tennis aud croquet grounds. N.. B. \& G. Co. 's Bonton Lawn Grass, qt., 3.5̃c., postpaid. By prese or freight, qt., 25c.; peck, $\$ 1.25$; $21, \$ 4.50$; hags included. In 5 bil. lot $\$$, $\$ 4.00$ per bu.

N., B. G. CO.'S PARK MIXTERE.-This is a fine mixtnre, the grasses nsed in its comhination heing equally as good as those in the Boston Lawn Mixture, bnt not containing as many varieties or some of the high priced sorts nsed in the Boston Mixture. It has given exPark matisfaction and we commend it to those not wishing as expensive a mixtnre as Bostom. N., B. \& G. Co.'s LAWN GRASS, Good Mixed.-Where \& fine lawn is wanted, we al
IV ways recommend that the best seed be ased. There are places, however, that are not conspicnons and where all that is desired is a good, healthy growth of grass, where a cheaper mixtnre will answer every pnrpose. No better Lawn Grass for the money can be ohtained than our Good SPECIAL MIXTURES. -We are at all times glad to make up spectal mixtures of Lawn Grass to meet the requirements of existing conditions. We have been very snccessful where combinations of grasses for terruces, shady places, exposed situatlons, etc., were wanted.

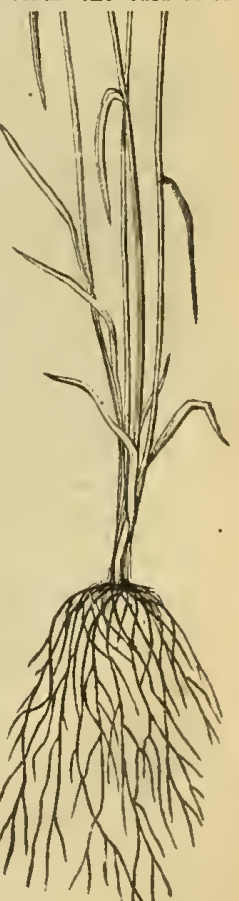

Root of Plant Shewing 


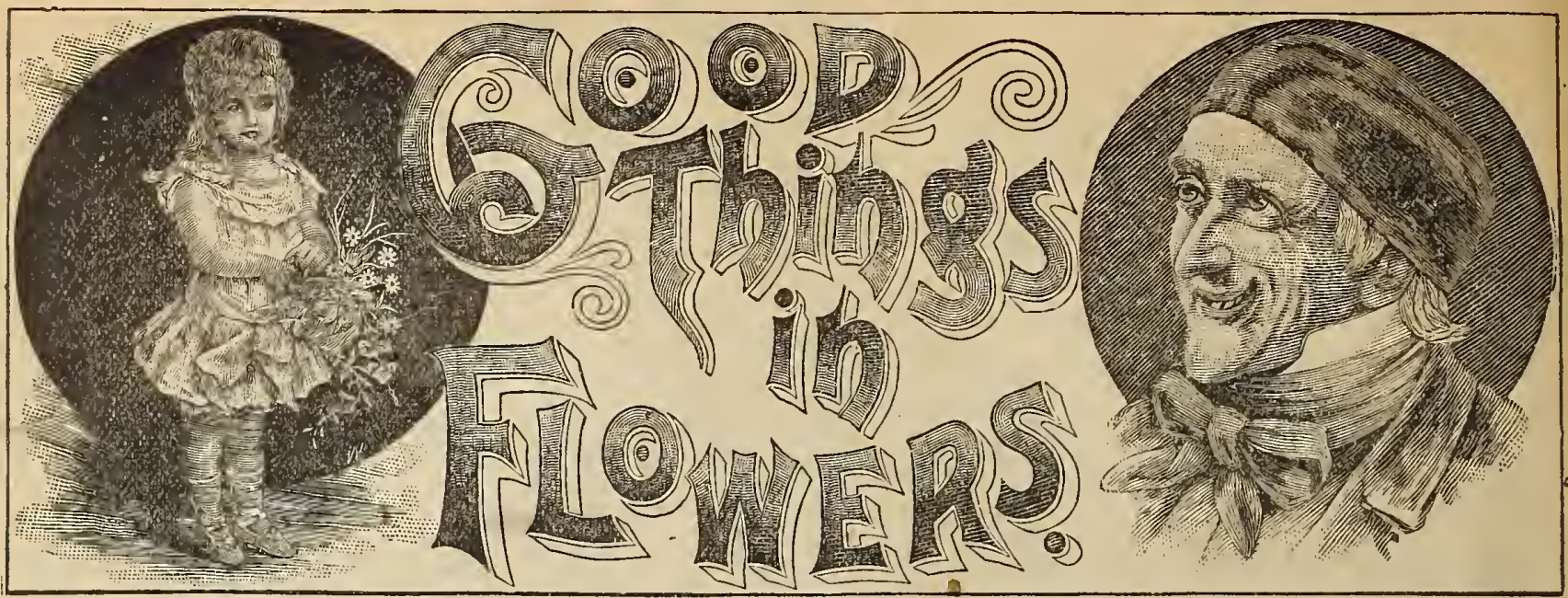

7577 E have endeavored to make our list of Flower Seeds a guide for the benefit of those desirous of growing only the

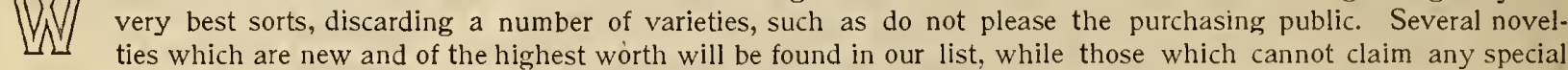
recognition on account of newness, are from first to last the very best, most showy and useful sorts, fresh, true to name and of good vitality. Everything offered is of unquestionable worth and deserves particular notice.

PREMUUMS. For each One Dollar sent us for Flower Seeds in Packets, the purchaser can select seeds in Packets to the
value of $\$ 1.30$. All flower seeds postpaid.
REMEMBER-Any Seeds in packets can be selected as premiums, but no Plants, Collections or Bulbs. 1. B. F. BO.'S IMPERIRL MIXTURES. We wish to call attention to our mixtures of important annual varieties, to which we have tended to embrace all of the very best and rarest colors, ard are made up really without regard to expense, our aim being to make them absolutely the best mixtures extant.

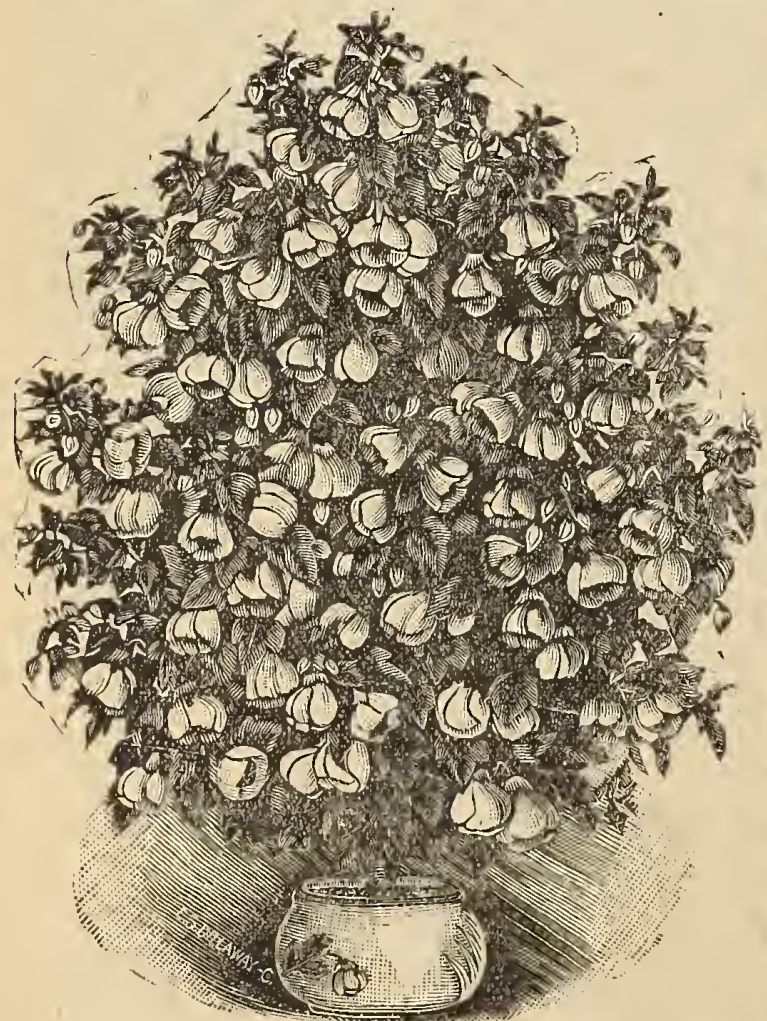

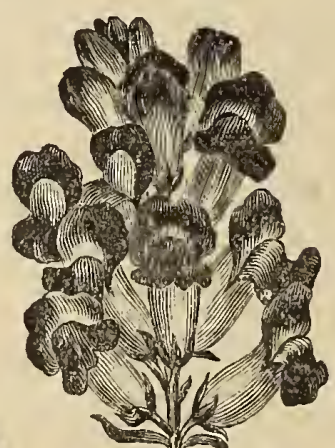

ANTIRKHINUM.

(Dwarf Snapdragon.

ANTIRRHINUM.

inapdragon. An old garden favorite with oddly shaped flowers, with pretty ly fragrant; one of the most sliowy and useful border plants. These are of every soil. and the tall sort yeld an abundingce of fine cut-flowers, while the dwarf sorts make the prettiest splendid mixture, pkt... $5 \mathrm{c}$. Dwarf sorts, finest nixture, pkt... 5 eents.

AGERATUM. 11ardy innual, desirable for eut flowers for boquets. bloomin the tarden. Blexieanum, packet, 5 cents.
ABUTILON (Chinese Bell Flower; also called Flowering Maple.) ABUTILON. This heautiful slirub, which is admirably adapted for winter house culture and for bedding out in summer, would undoubtedly be one of the most largely grown plants were it not for the impression that exists that it is difneult to raise. This is erroneous. The seeds, if started early in the house, under considerable warmth. Will thrive rapidly and the plants will bloom the first seasori. No plant better repays growth. It grows from is to 6 feet in height, and the fiowers, which are bellshaped and beautifully reined, are in eolor eacket, 10 cents; 3 packitis for 2 i cents.

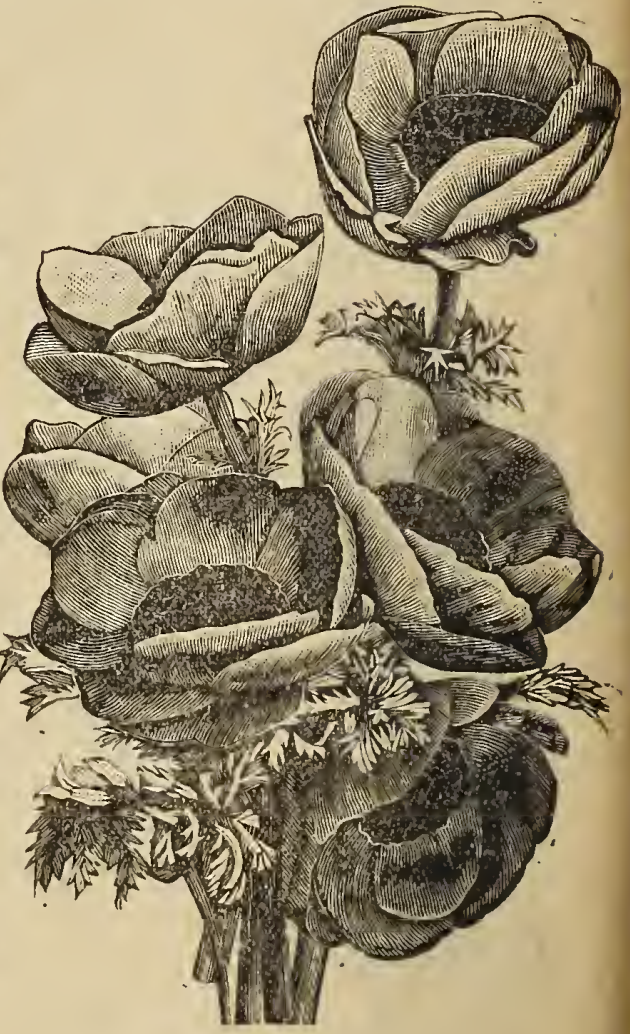

ANEMONE (Wind Flower.)

ANEMONE. (Wimd Flower.) These make very hardy, showy plants, about 1 foot high, with large saucer shaped fiowers of hundreds of shades of eolor, blooming early in the spring when few plants ean conpare with them in beauty and brillianey. Fine for bouquets. colors mixed. P'lit., 10 cents; ounee, 40 eents.

AMARANTHUS. (Love Lies Bleeding.) Valuable for its variety of handsone foliage. Tri-eolor splendens (the finest). Pkt., 10c- 


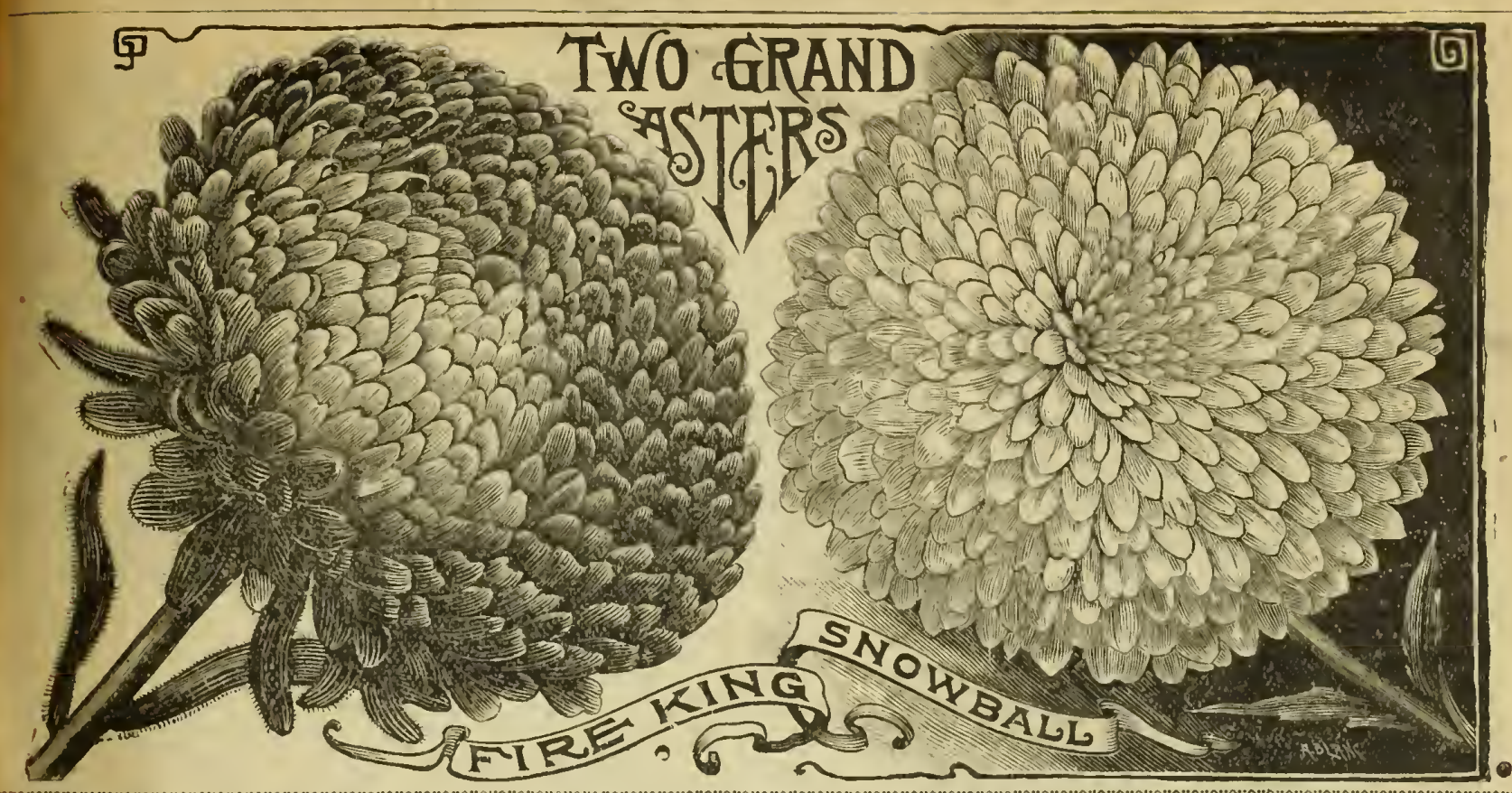

THESE two superb Asters, Fire King and Snowball, are decided acquisitions to the already large variety of these magnificent flowers, We offered them two years agro for the first time, and they have well maintained the right to first place this
season. The brilliancy of the Fire King and the purity of the Snowball are best enhanced when planted side by side, each developing the peculiar beauty of the other. Fire King grows about 12 inches in height with large, brilliant scarlet incurved flowers, completely covering the plant. Snowball is also a dwarf variety, of symmetrical habit, 10 to 12 inches in height, with pure snow white flowers, regular, imbricated, globular in form and of extraordinary size, the plants bearing from 10 to 20 flowers. Price per packet for either variety, 15 cents, or one packet of each for 25 cents.

N. B. G. GO,'S IMPERIAL ASTERS.

MIXED. Our Imperial Mixture comprises Ill of the best strains of Asters, selected with a vlew to yielding the best display of types and colors. IMPERIAL, GERTAN PANSIES and ITPERIAL. SWEET PEAS have won for themselves a name with thousands of flower lovers all over the United States as the best mixtures obtainable. We can assure our patrons that our IMPERIAL IIXTURE OF ASTERS is fully up to the standard attained by the specialties men sloned. Extra large pkt., 25c; large pkt. I5c; pkt., 10c.

GHRYSANTHEMUM FLOWEREO.

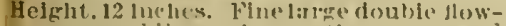
ers. lesembing chrysanthemums and erlng whe'tl ol hers are cione. All eolors. NEW VICTORIA.

Howers arere gant regular overlapping of the petalis The plituts lear from 10 to 20 llowers. Wlt Oultedistinet. NEW WASHINGTON.

geet. Without exception tine largen Aster in rillivation. flowers frequentis of perfect. form. All colors. mixiol. I'atek WHITE PLUME

ertily distluct form of these propular therers. being the intreduction of all fingiish long, fat and reflexed, as white own entras ing, greatly resent)ling a (chrysanthemum in appearinece. It is not only tIfnl. Plit... 15 cents.

\section{SPECIAL ASTER OFFER}

We will mail one packet each of the "Flre King," "Snowball," "N. B. G. Co.'s Imperial Mixed" and "White Plume" for 40 cents.
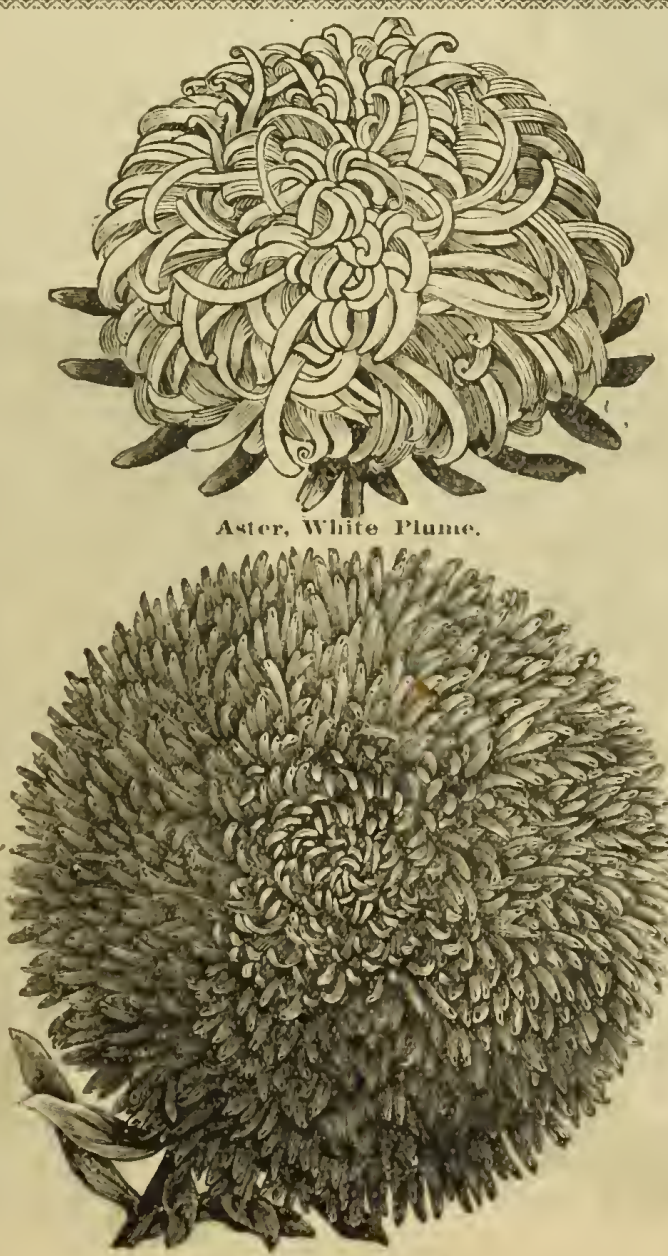

Washington Needle Aster.
SHAKESPEARE OR DWARF POMPOK.

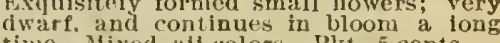
COCARDEAU OR CROWN.

Meight, 1/2 leet. A very showy variety. centre petals being pure white, and outLARGE ROSE FLOWERED.

Tentury

COMET. 1leight. 12 to 15 inches. Suite nistinet flom other sorts in shape lowers 3 to t luches weross their long wavy ind t.wisted petals forming a louse
yet denso hat giobe, resembling is largefowered Japanese c hrysanthemun, each petal a delleate pink, margined with PEONY PERFEGTION DWARF,

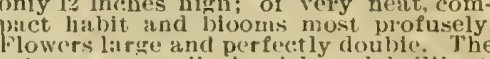
colors are peculiariy rich and briliant. trongly recormmended for planting eith-
ar In beds or masses. Mll colors, wixed. DWARF QUEEN. The pluest dwarf bustiy plants alout 10 inclies ligh, of compace habit of growth, produceing : Aster. It is excellent for bedding and pot Quicen, plit., 10e; gueen Aster, mlxed IMPROVED QUILLED GERMAN. Einest GHOICE YARIETIES MIXED.

\section{ASTER COLLECTION}

For 60 CTS. we will mail one packet each of the 15 varleties Asters offered on this page. TE:S IS OSIL 46 PEZ PET. 


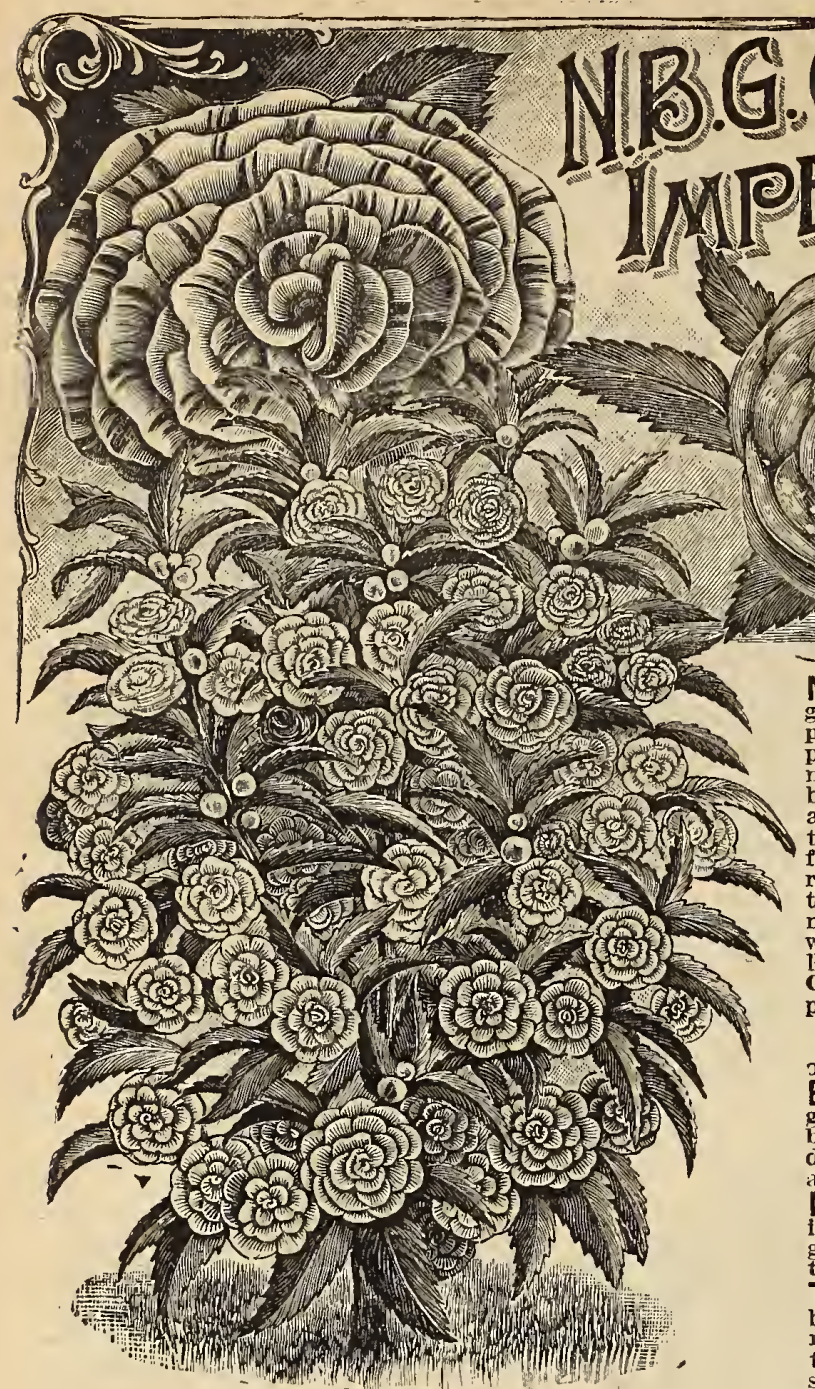

N. B. G. CO.'S IMPERIAL BALSAMS. (DGuble.) Unrivalled IS reat variety of color and size of thower. Under the old names, "Lady Slip
per" and Touch-me-Not," Balsams have always been popular, but a new in
petus has been given to their culture by the improvements thut have bee een greatly yereased. While showy ln growtl, and forming one of the na the nowne otted, Blue, Purple and many other tints and varieties. Carnation Striped, pkt., 10 cts.; Camelia Flowered, pkt., 10cts.; Rose Flowcred, We wlll mail 1 packet each of the four last named sorts for $25 \mathrm{cts}$.
ats mitted from any garden. The newer double sorts will prove a surprise.

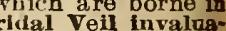

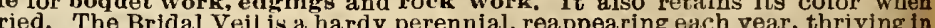
NEW BECONronounced a are of a brilliant orange carnine color and the foliage a glossy red whlch chroumbout thense with the advancing season. It blooms with great profusion TUBEROUS ROOTED BEGONIAS, Mammoth Flowered, Far brillancy and variety of colors there is nothing to equal these flowers whicu umn. From one packeues af seed, bulos by the hungred can be raised in oue

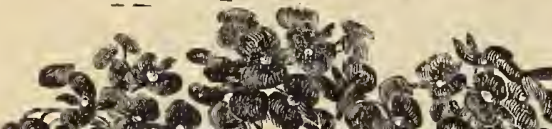

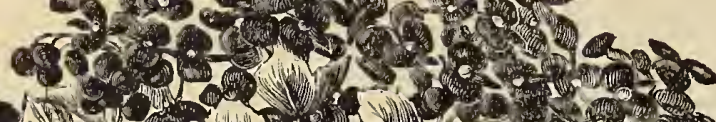
C. Th

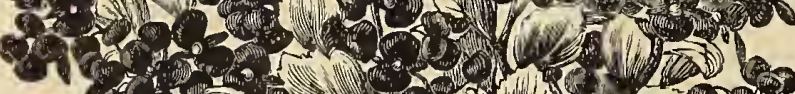
9.6.

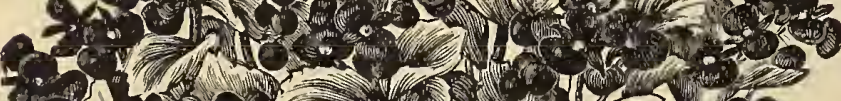
6.7. $\Rightarrow$. c.

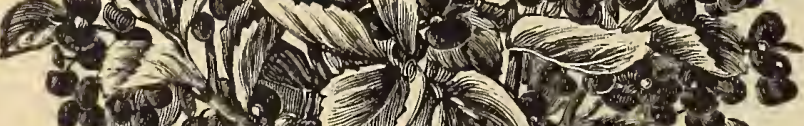
V.x.s.

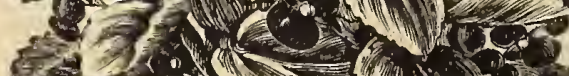
E. 1) D) Ans mormo r.

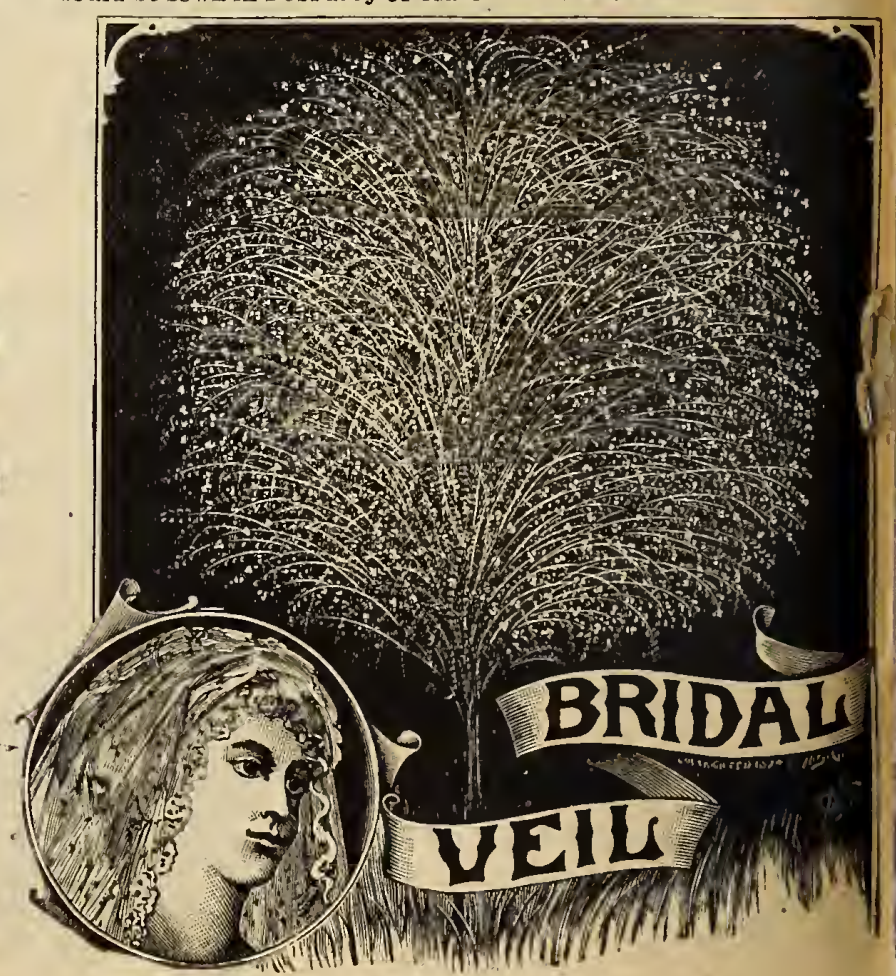




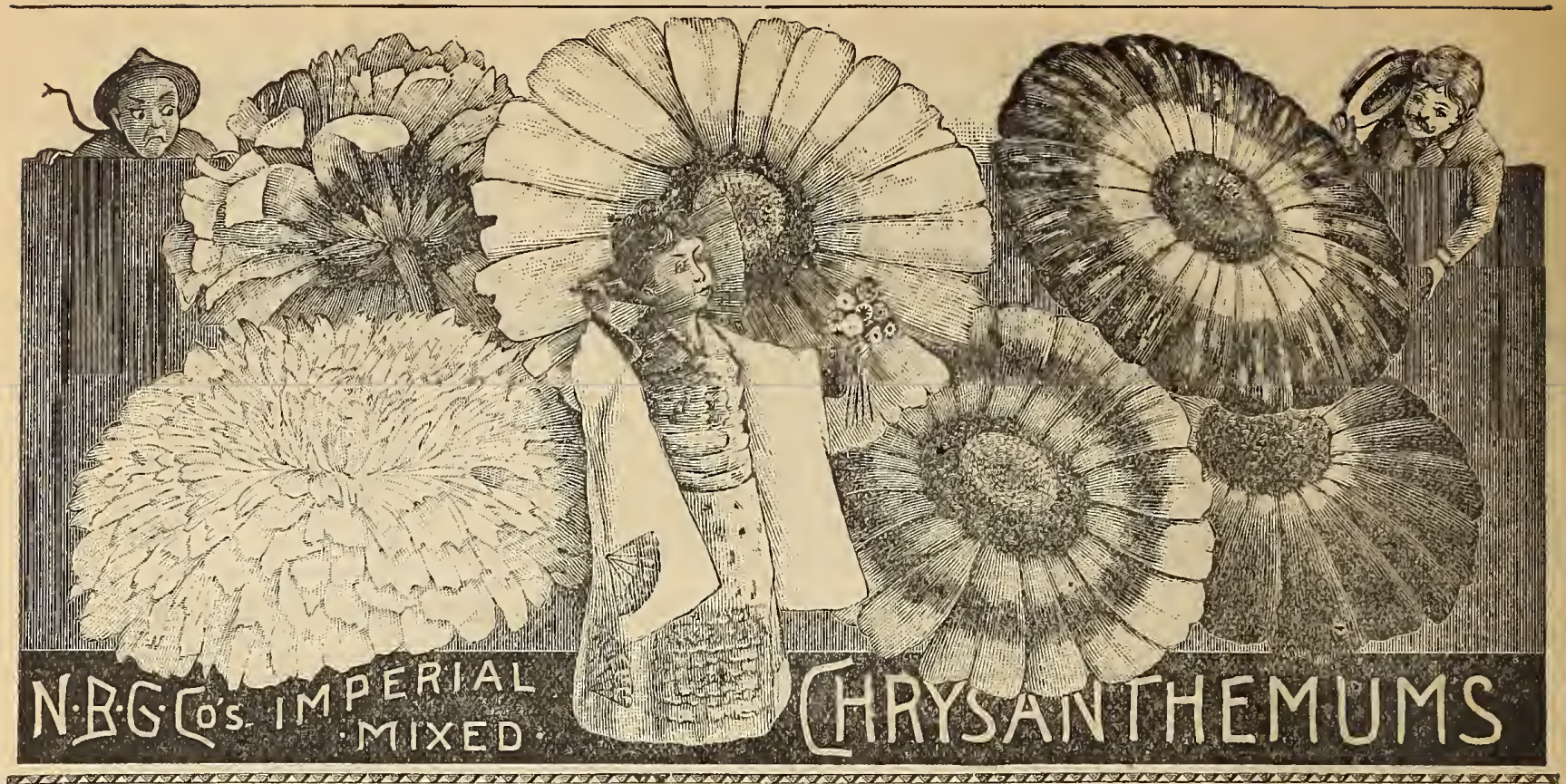

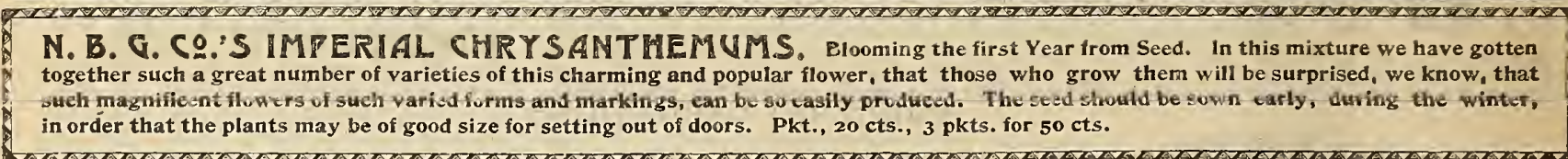

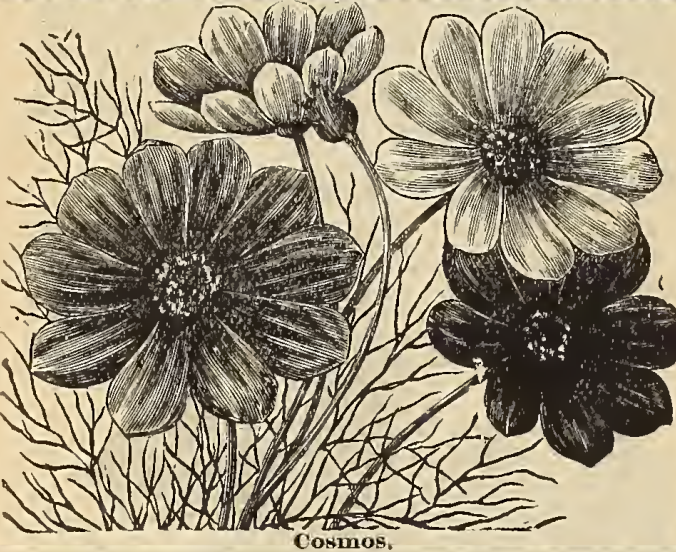

COSMOS. This plant is of strong growth, having elegant foliage, and for fall blooming has no May and trausplanted to open six feet high by Sept. and from then till November will be covered inches across, resembling single brought inside to flower, like chrysare of various shades from pure foliage and flowers are unsurpassed of the most beautiful of tall flowHybrids, all colors. Pkt., $10 \mathrm{cts}$; 3 for 25 cts. Pure white "Pearl," Pkt., 10 cts.; 3 1or 25 cts.

CINERARIA. These are usually considered greenhouso plants from seed sown indoors. and will repay any labor expended upon them. These and Primulas are, perhaps, the most satisfactory of all house plants, not only on account of the extreme beauty of the flowers, but by reason of the long duration of bloom. These flowers measure 2 to 3 inches across, and are white, blue, violet and crimson in shade. One peculiarity of the Cineraria which impresses

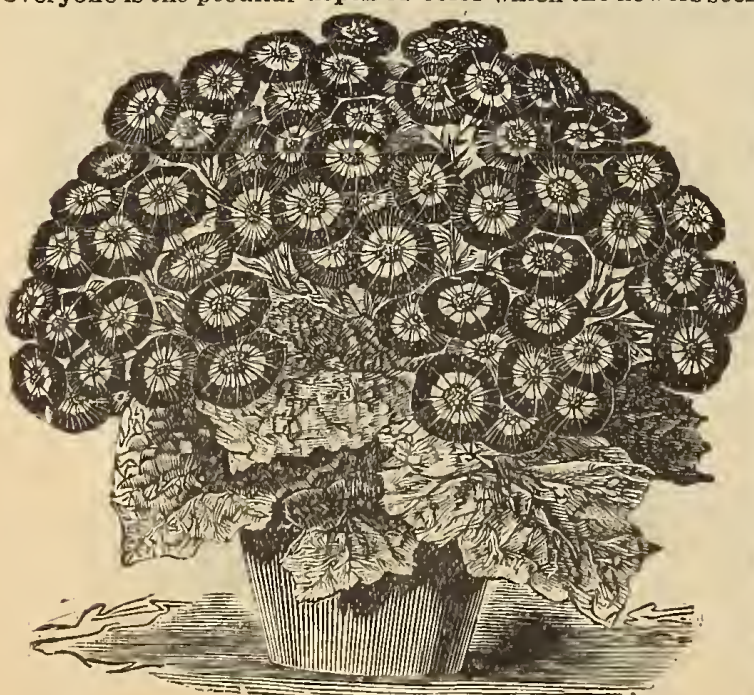
Hkt., 25 cents.

COXCOMB. (CELOSIA.) QUEEN OF THE DWARFS. This is certainly the finest Coxcomb. It grows only about 8 inches in height: the combs are from 6 to 10 inches across, of perfect form and of brilliantdarkscarFEATHERED OR PLUMED.(Celosia Plumosa.) Handsome pyramidal plants, 2 to 3 feet high, producing at the summit of plumes of graceful character. finestmixed.Pkt.10c;3 pkts 25c. CANDYTUFT. (Snow Queen.) A new annual variety from Southern Europe, growremapidy, blooms early and threers in tul Tower for about grows very regularly-ach plant being almost an exact and shows of every otherbridizcd. It is invaluable fo ribbon beds or borde
$10 \mathrm{cts} . \mathrm{i}^{3} \mathrm{pkts} .25 \mathrm{cts}$.

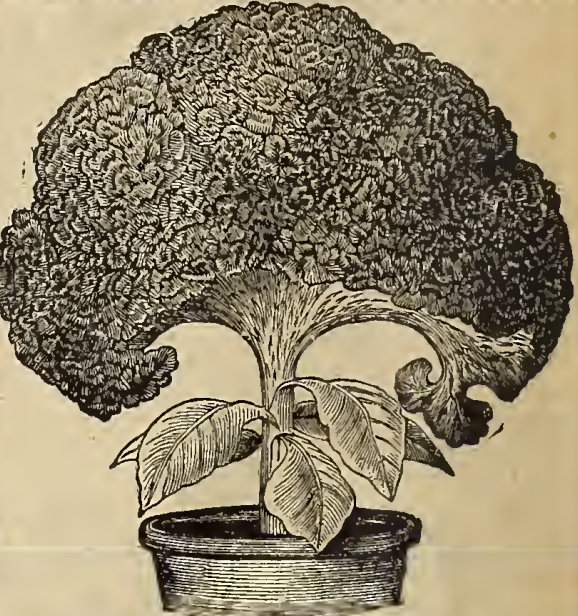

Coxcomb, Queen of the Dwarfs.
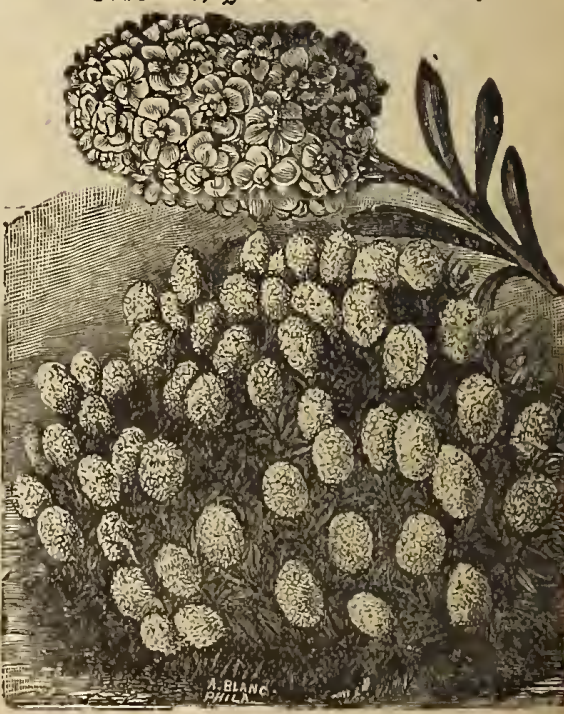


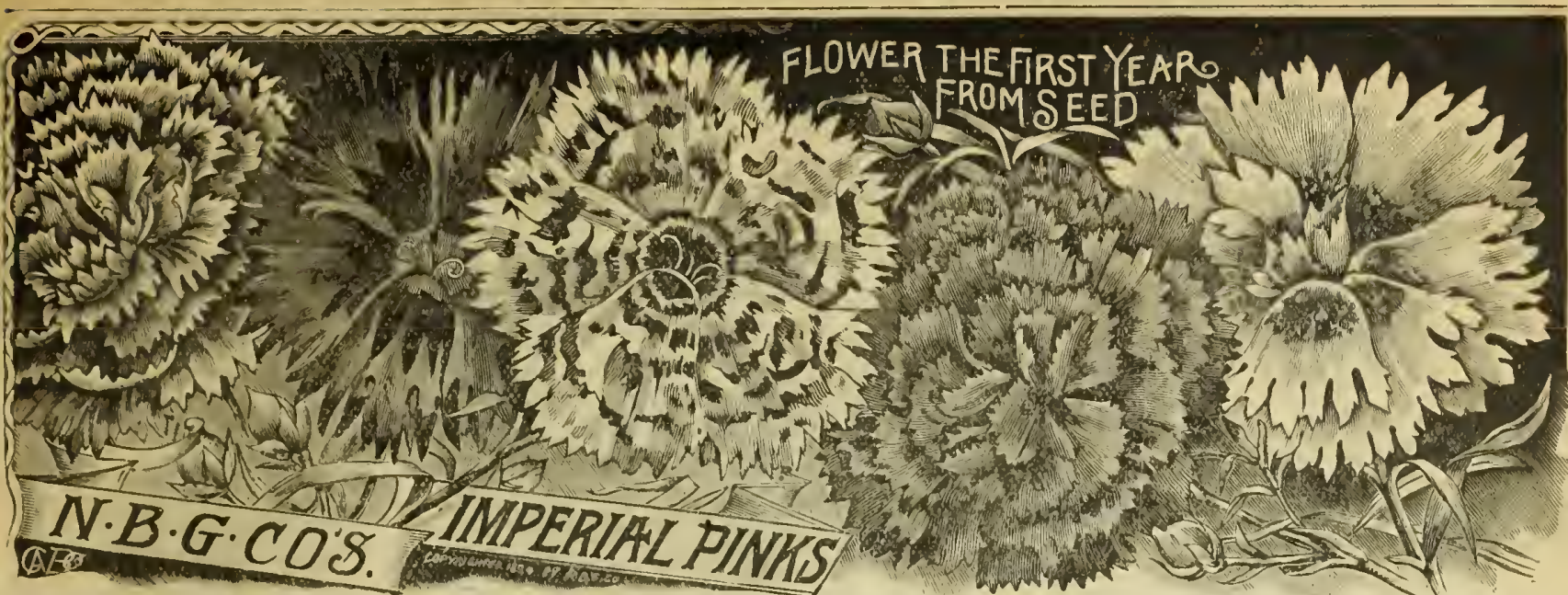

DIANTHUS. (Chinese Pinks.) BLOOMING THE FIRST SEASON. Certainly these are among the most useful and desirable plants. For beauty and variety of colors and markings, they cannot be surpassed, ranging from pure white to the most delicate pink and glowing deep crimson.
The mixture we ofier is a selection from over $z 0$ different strains, and cannot fail to give entire satisfaction. To be properly appreciated they should be seen growing, as it is impossible, in our limited space, for description to convey in words any idea of their beauty; and in large beds you can hardly ind two alike. A bed of these in the

\section{DAISY. (BELLIS PERENINIS.)}

Daisies can be easily raised from seed sown in the Spring.

SNOWBALL. Is a large and very double pure white; cutting. Plt 10 che 3 plits

DOUBLE QUILLED DAISIES.

as the

bel

a loamyer cool border

Qulled" is a new straln, the flowers of which are eomposed of petals as round as a knitting

\section{DAHLIAS.}

It is strange how few people know that Dahlias can be raised from seed and BLOOM THE FIRST YEAR. A packet of seeds will produce
not less than fifteen plants which will cost if purchased as bulbs, over \$1.00. The seed we offer is saved from the cholcest varieties only. BEST MIXTURE OF DOUBLE DAHLIAS. mlxture of the best large flowering, Pompone and Lllllput Dahlias, partly from separate

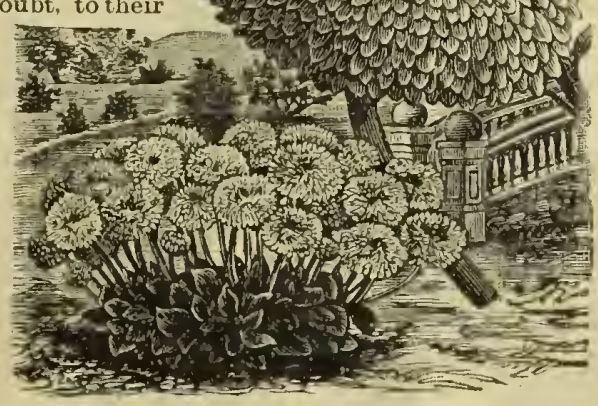

Snowball Daisy.
NEW SINGLE DAHLIAS.

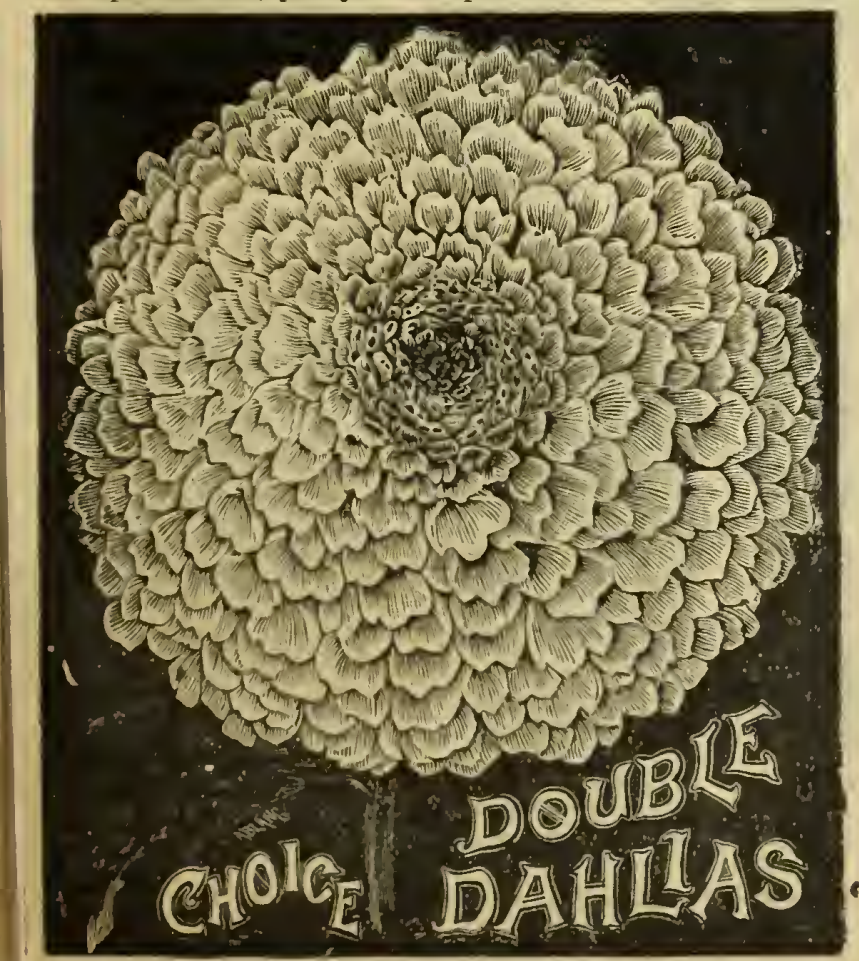

ROSE CARDINAL. Very pretty deep carmine, Pkt., 5 cts.

N. B. G. CO.'S special mixture California Poppies includes Nil B. G. CO. S Special mixture California Poppies includes

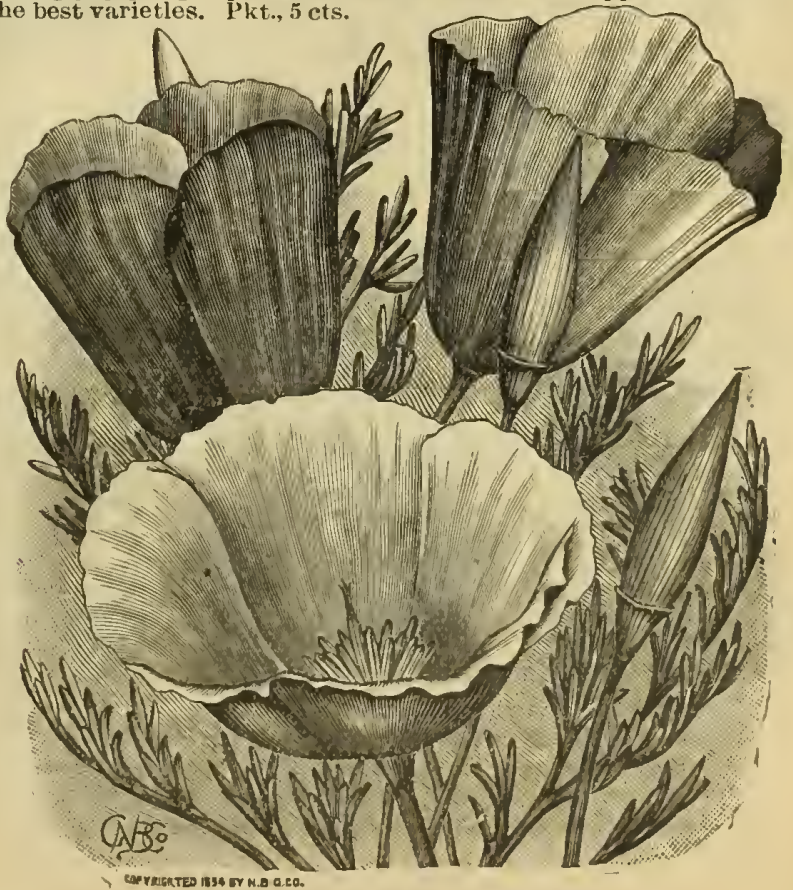



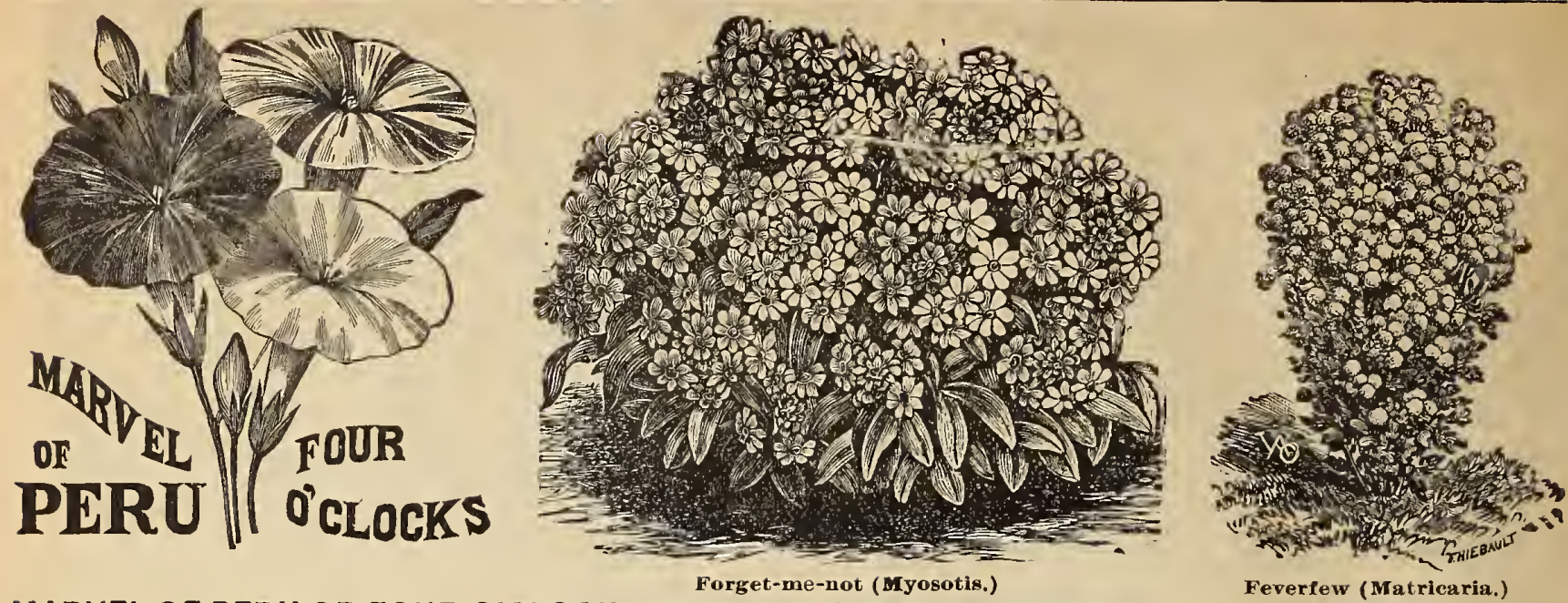

MARVEL OF PERU OR FOUR O'CLOCK. For beauty of foliage and flower combined, this handsome plant lias few compeers; their colors are vivid and of great variety; one of tho most The flowers open in the afternoon. Pkt., $5 \mathrm{cts}$.

FORGET-ME-NOT. (Myosotis.) Bushy plants, 6 to 12 inches high, bearing clusters of lovely smail flowers. They are perennials and hardy enough to remain in the open ground, excepting in very cold latitudes, where they should be well protected; but they are generally sown in the fall and wintered over in cold frames, when they will flower early in the spring; if sown early in house will flower (

GERANIUM. These favorite plants are easily raised from seed, which will frequently reward the cultivator with charming new varieties; in fact propagation by seed is the only sure way to obtain new varieties. Extra

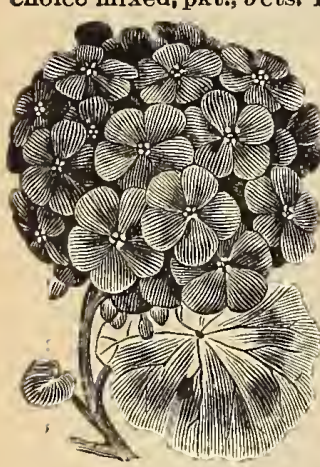

Geranium. pkt., $25 \mathrm{cts}$. GAILLARDIA. (or Blanket Flower) This now wellknown flower is undoubtedly one of the most valuhave for cut flowers. Our seed ment on the older sorts, producing very round as a perfect ball in the most varied and pleasing colors. The on long, slender stems and when over a week. Pkt, 5 cents.

GODETIA. Beautiful hardy annuals, remarkable for their very fine large blossoms. mine crimson, lilac with purple and rich satiny white. Pkt., 5 cts.

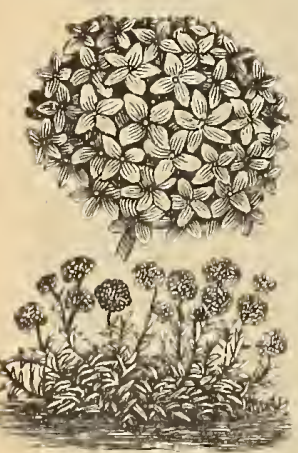

Gaillardia,

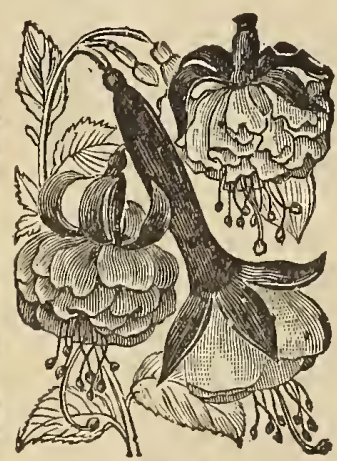

Fuchsia.

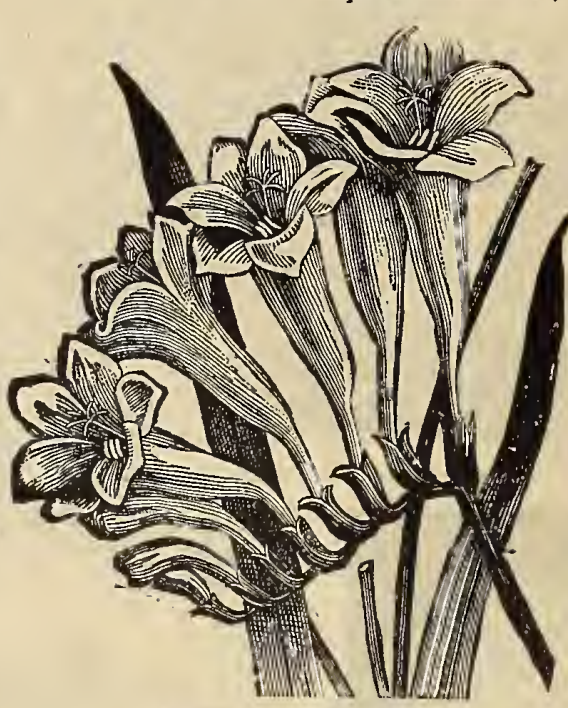

Freesia Refracta Alba.

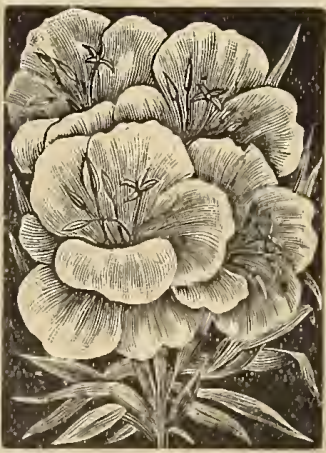

Godetia.

DOUBLE FEVERFEW, (Matricaria Eximia.) Handsome as desirable as a ood Aster, very trea flowering or for pot culture; FRE

FREESIAS. These pretty bulbous plants, with their sprays of very fracrant and pure white flowers can be raised from seed and made to bloom the first year. The beauty and delicate fragrance of GOURDS. Tender annual climbers, with curiously shaped fruit in various colors, many of which are peculiarly niarked. The foliage quite ornamental, and many of the fluits being hard shelled can be kept for years. Fine mixed, pkt., 5 cts. FUCHSIA. Fuchsias are as easily grown from seed as cuttings, and from seed many new varieties are obtained. They will flower the plants can be taken in the house in the. winwill flower still more freely. Pkt. $25 \mathrm{cts}$

GLORY PEA OFAUSTRALI (Clianthus, Although this is ennial greenwouse shrub, it first season from seed sown in the open ground in the spring. The plant attains a feot, bearing

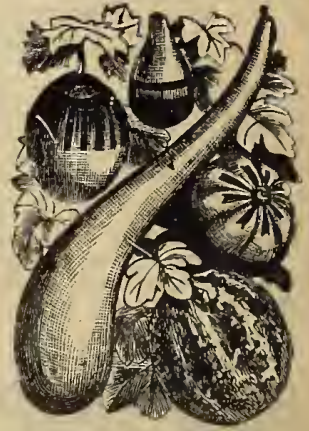

Ornamental Gourds. clusters of drooping, brilliant, rich scarlet, pea-shaped flowers, three inches in length, each flower picturesquely marked with a large black blotch in the center. Pkt. $10 \mathrm{cts.:}$ GLOXINIAS are grown readily from seed. and, in this way produced at nominal variety and brilliancy of bloom. Seed pkt. $25 \mathrm{c}$.

Clyde Dean, Portland, N. Y., writes: "The Aster Seed we bought of you proved a brilliant success as to number and quality of Plants and Flowers; also the Gladiolus Collection was a decided success."

Ella Drager, Medford, N. D., writes: "I am very much pleased with the flower seeds which 1 got from you Iast spring. They all came up very nicely." 
HOLLYHOCK, MARIGOLD, HELIOTROPE, HIBISCUS.

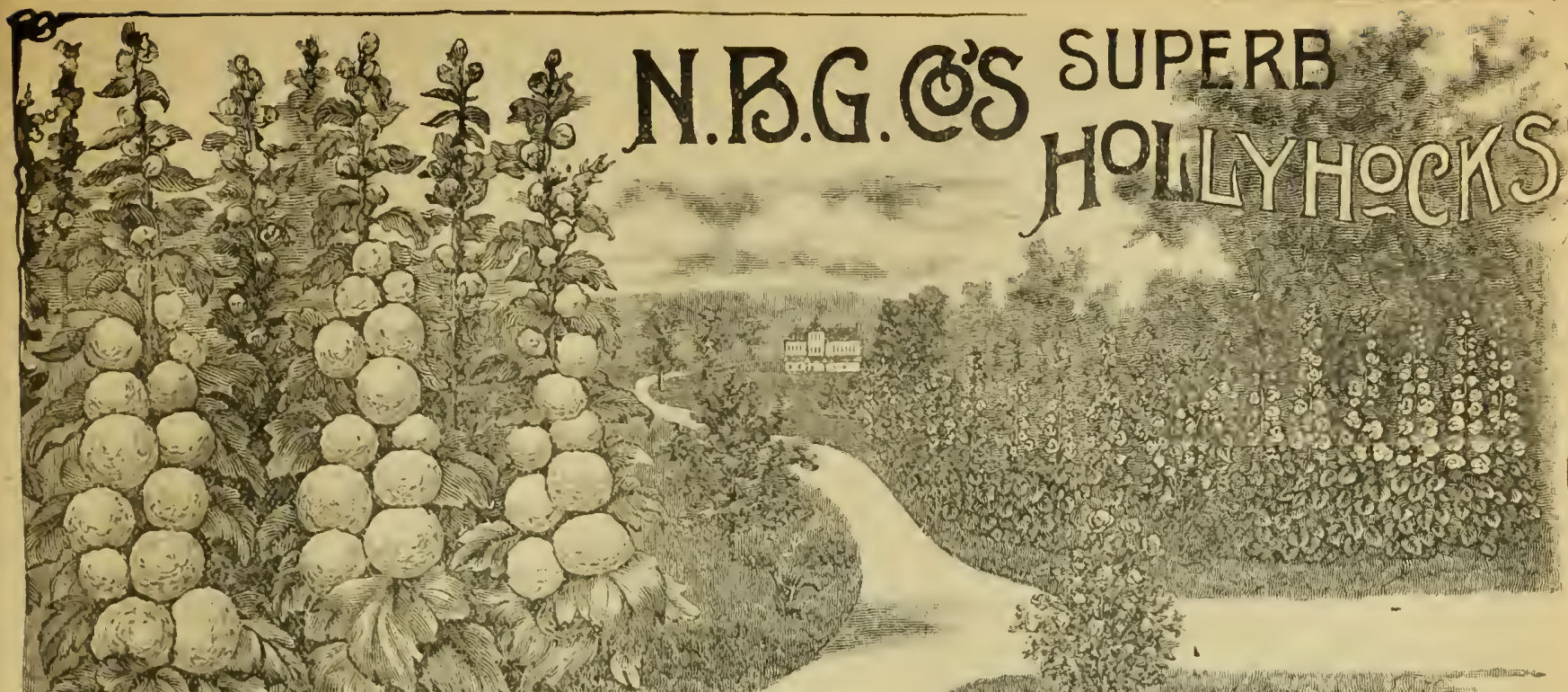

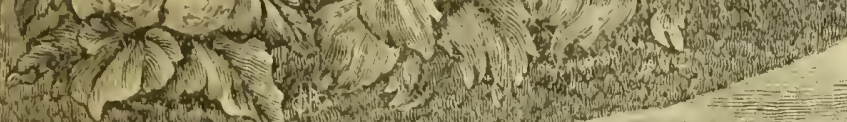

HOLLYHOCKS

whinch are inlinis

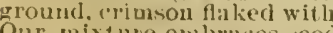

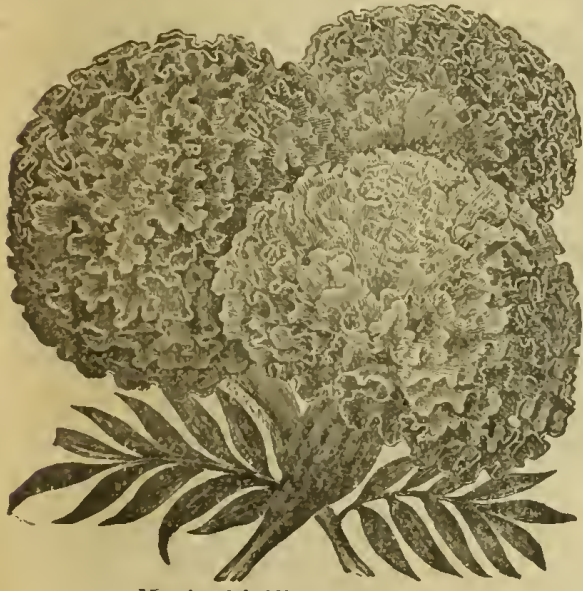

Marigold, The Eldorado.

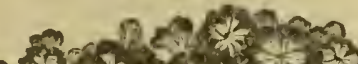

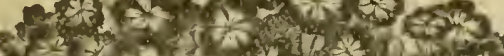

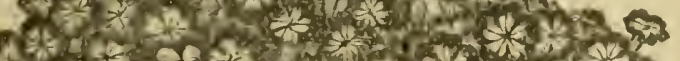

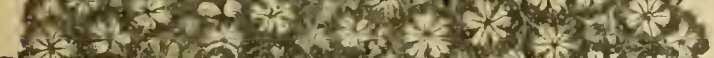

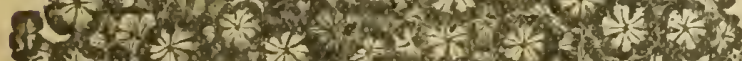

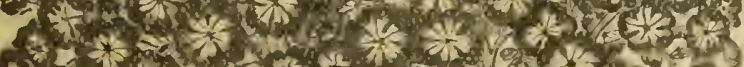

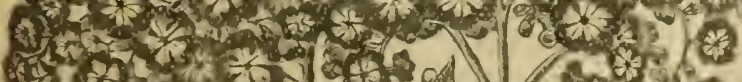

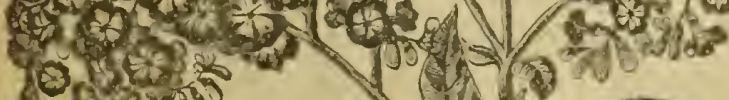
Yorojosts

ogsen

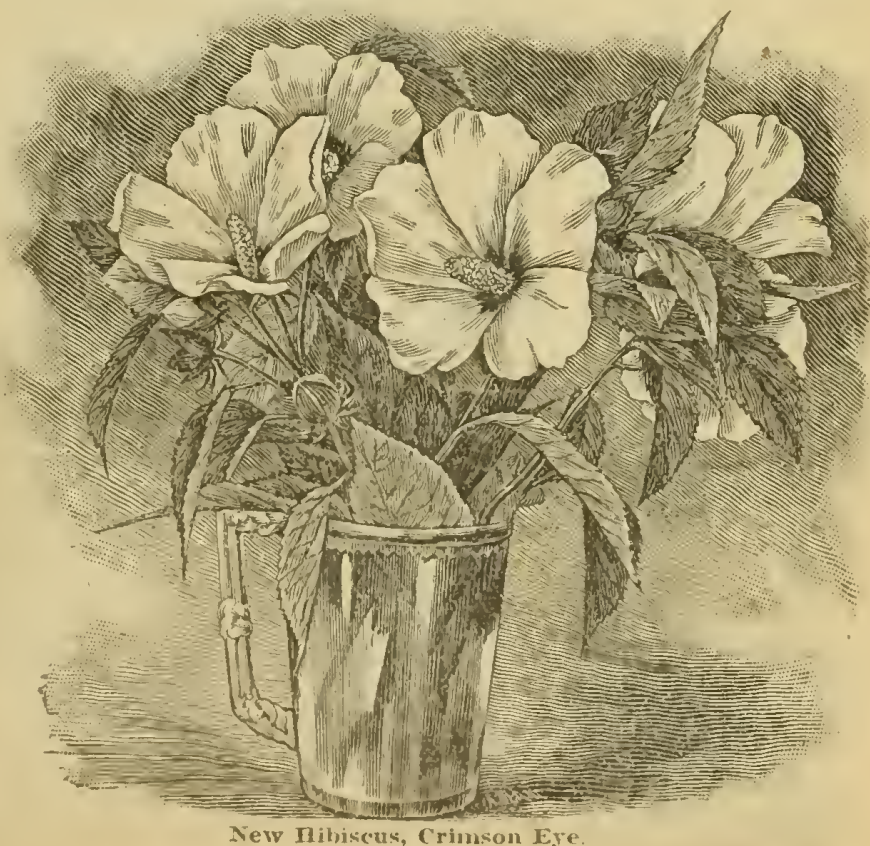



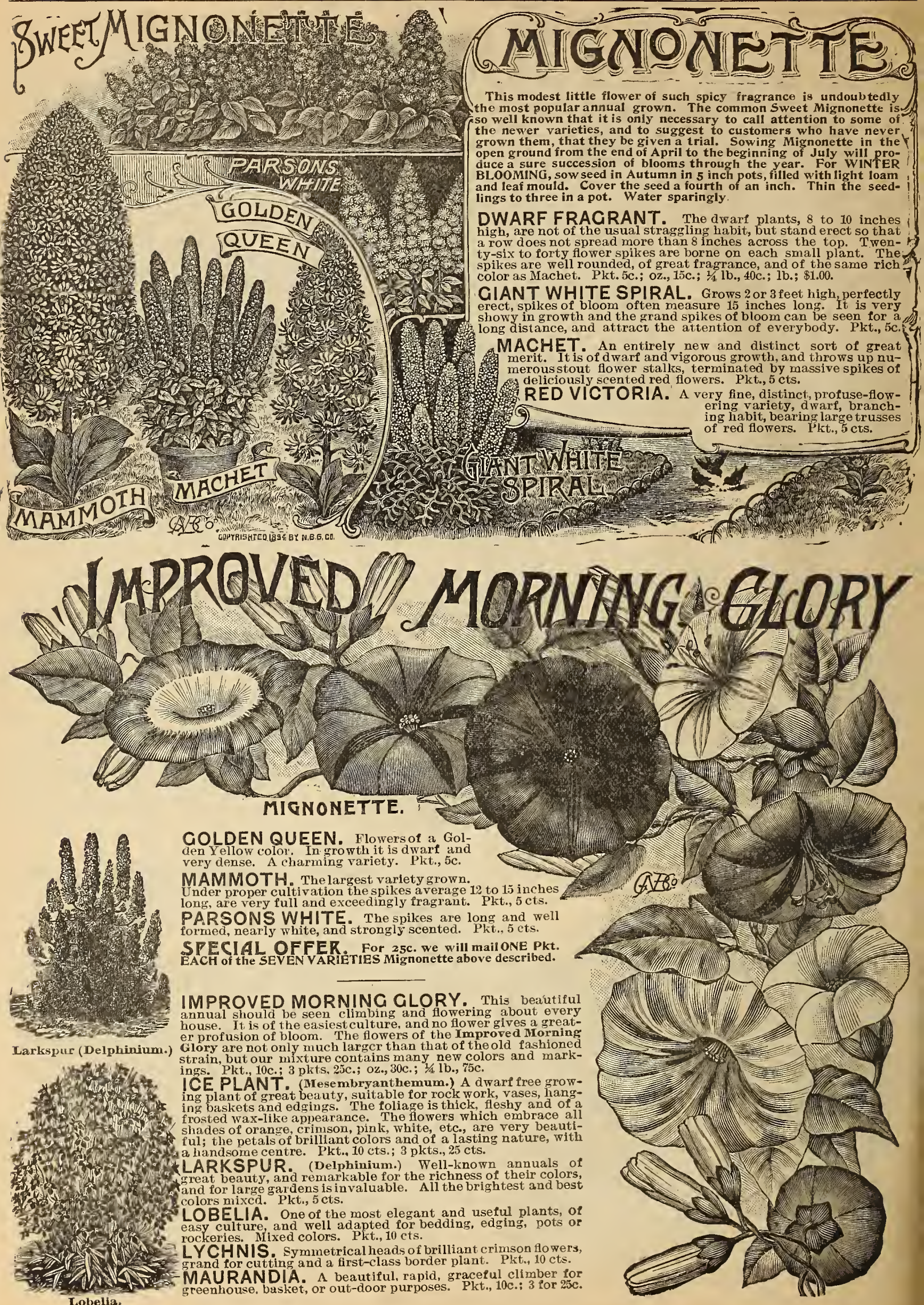
NASTURTIUM, NICOTIANA AFFINIS, NIGELLA, NEMOPHILA, PETUNIA,

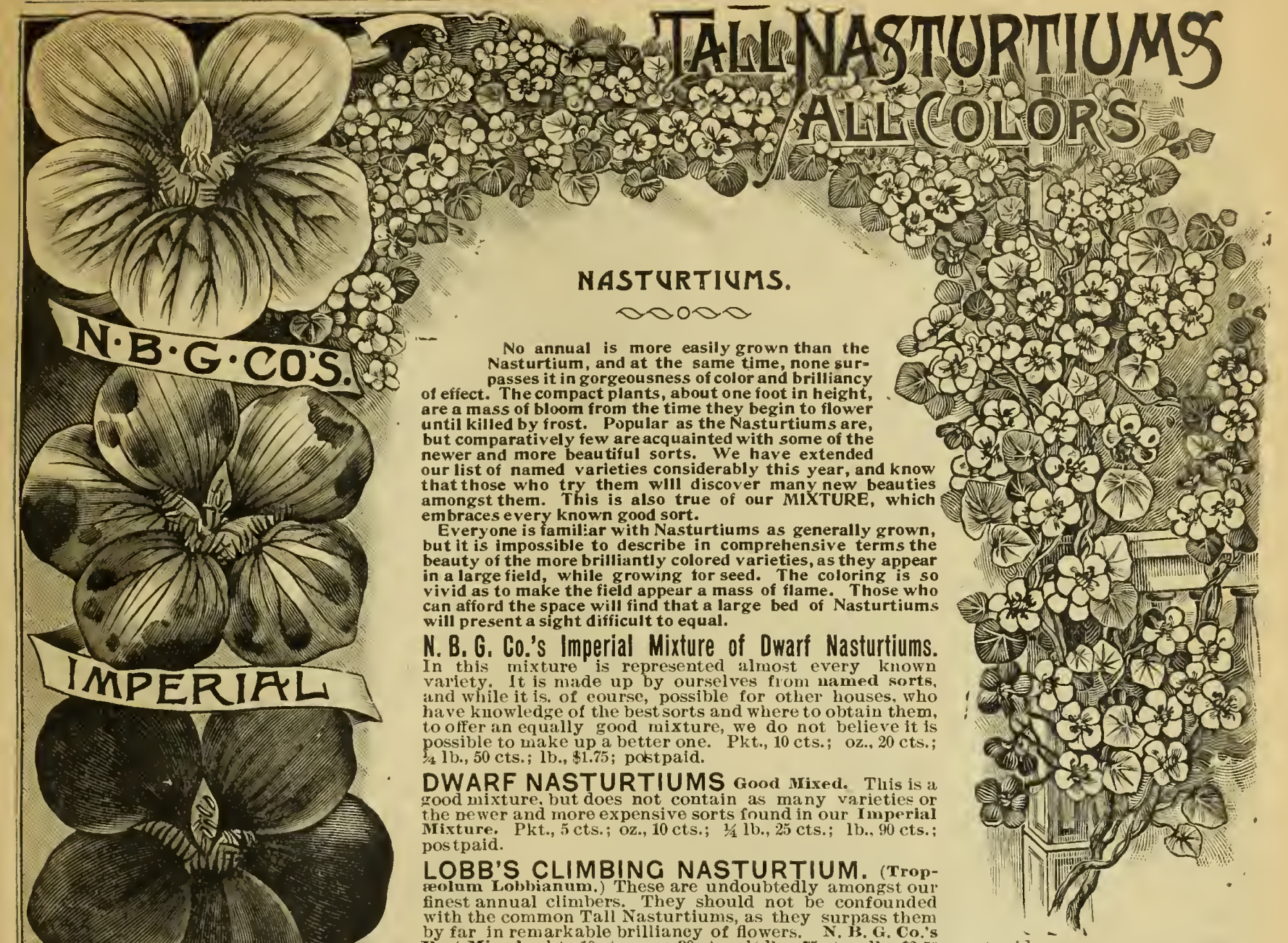

IN SEPAR ATE COCORS: J3rilliant (vi id ; (beautiful pure yellow), Cardinal (bright), Chestnut Brown (very rich) Spitfire (brightest scarlb., \$2.50. Canary, plit., 10 cts.; oz., 35 cts.; 1/4 1b., $\$ 1,00$; lb., $\$ 3.00$.

TALL NASTURTIUMS. This is a capital mixture, but the flowers do not possess the NICOTIANA AFFINIS. The Nicotiana Affinis is another reliable white flower for the garden. It is a robust grower, blooms most profusely hroughout the season, being one of the list to go down beneath the touch of the Frost King. Its beautiful silvery stars open out toward perfume and close acain when the sun

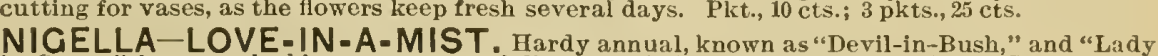
NEMOPHILA-LOVE GROVE. For ribbon borders and garden decoration. Pkt, 5 ct

PETUNIAS.

DOUBLE FLOWERING SORTS Frlnged. This extra choice strain produces about 30 per cent. o Pkt., 25 cts. Exira Large FlowerLake." "This seed will produce about $30 \mathrm{per}$ cent. of double whit N. B. G. CO.'S DOUBLE PETUNIAS Consists of a mixture of the best cluding the fringed varieties. The seed we offer is saved from plants and will produce someextra choice N. B.G.CO.'S MIXTURE of Large Floweriug Petunias. This ing ture embodies all the best varieties and will prove a pleasant surprise great deal. It contains all the od and notable kinds. Black, crimson. Ge. NASTURTIUMS: variegated etc 50 cent

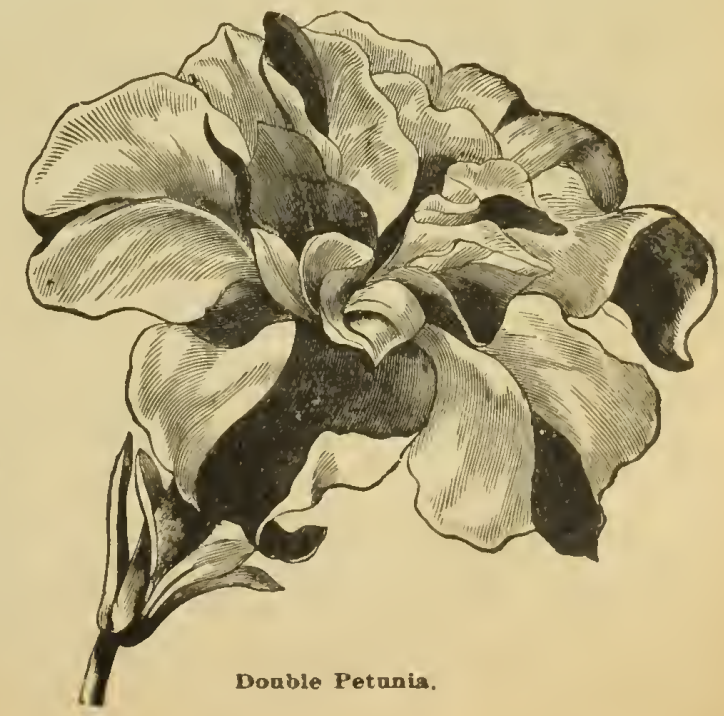




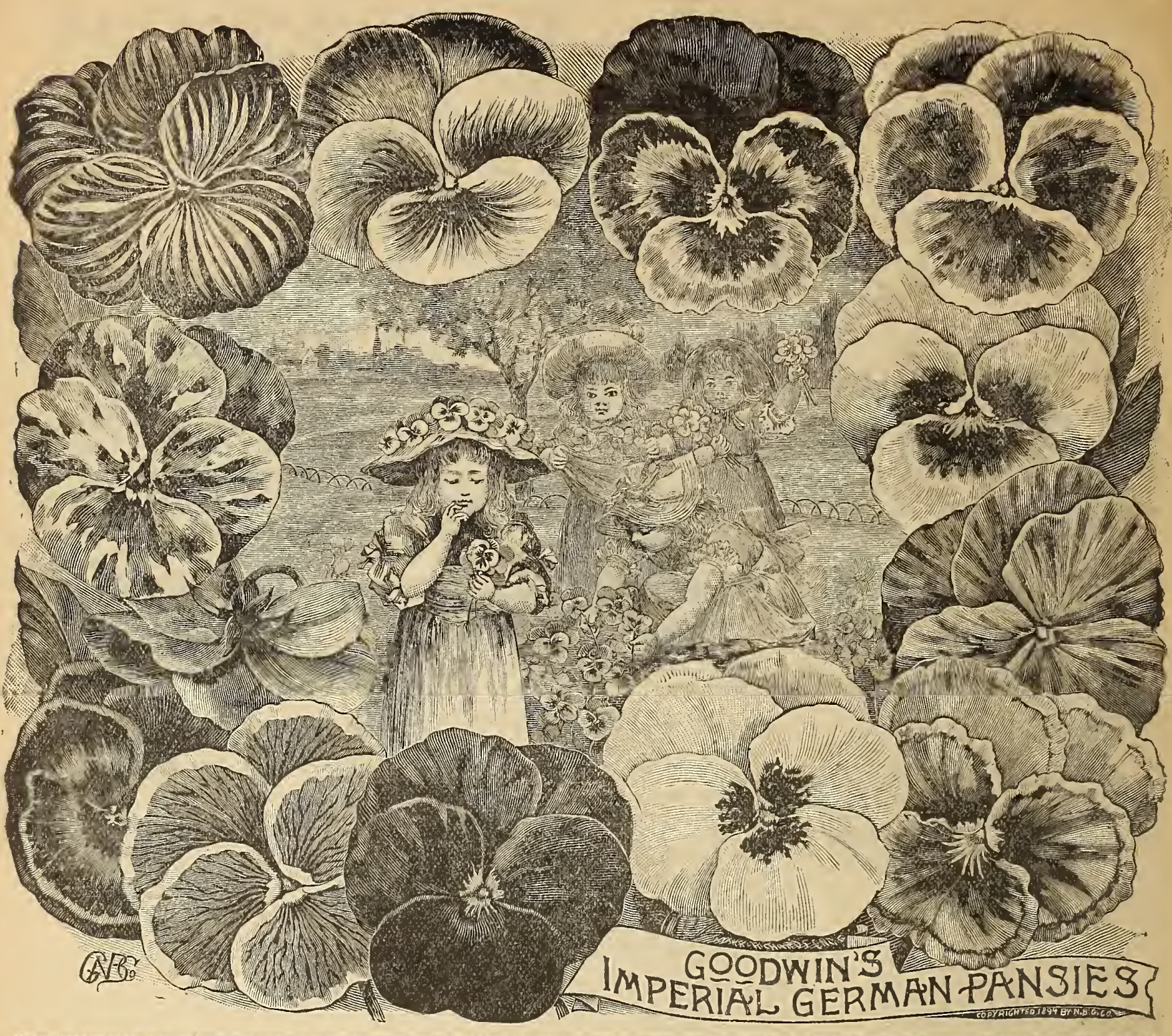

Unrivalled for Size, Diversity of Coloring and Mlarking, Beauty of Form, Satiny Texture and Free Flowering Character.

While we claim GOODWIN'S IMPERIAL GERMAN MIXTURE of Pansy is UNRIVALLED, we can also say that we have never seen its equal. It embraces all the solid or self colors, and contains those with ground color, light yellow; the lower petals blotched violet, the upper petals carmine, edged with white; others with clear, cistinct eyes, dark and light marbled varieties, large spotted, blotched, mottled, striped, chocolate, lilac, white borders, and an almost endless variety of charming shades of color that cannot be procured in any other mixed strain of Pansies (over sixty colors and markings) including several new and grand sorts secured this season. We assure our patrons that we will spare no effort nor expense to maintain the superiority of our "IMPERIAL GERMAN" mixed Pansy Seed in the future as we have done in the past, as the FINEST IN EXISTENCE. The method we pursue In making this mixture is to use only the RAREST and BEST SORTS, REGARDLESS OF EXPENSE, and then establish a price as reasonable as we can afiord. Packet containing 50 seeds, $15 \mathrm{cts}$; 100 seeds, $20 \mathrm{cts}$.; 600 seeds, \$1.00; 1,000 seeds, \$1.25; 1/80z., \$2.25; 1/4 0z., \$3.50; 1/2 oz., \$5.50; oz., \$10.00.

MARKET GARDENERS and FLORISTS are finding that the sale of Pansy Plants is one of the most profitable items of their trade. The flowers of our Imperial German Mixture are so large and the colors so varied and beautiful that they outsell by far any strain with which they have ever come in contact. Our customers always come to us again for their Pansy Seed.

We assure our patrons that it is no exaggeration to say that we could fill a book the size of this Catalogue with testimonials we have received from thousands who have bought and grown this strain of Pansy. So sure are we of the superiority of our German Imperial Pansy Mixture, that we wish to say right here that we will refund money to any who may buy it, and not be entirely satisfied with it.

John H. Watson. Perry, N. Y., writes: "The Pansy seed I received from you two years ago proved very fine, and the flowers were adBertha E. Lee, Clyde, N. Y., writes: "We have ordered seeds from your firm for some time and are pleased to say that your seeds have s,given the best sittisfaction. P'ansies were magnificent." Lola Grigsby, Calistoga, Cal.. Writes: "All the seeds I have ever bought of your firm have given splendid satisfaetion, espeeially Pansy
eeds. The flower's from the Pansy plants were betutiful, and the plants so strong and healthy." 


\title{
THE PEACOCK.
}

\author{
A NEW PANSY.
}

This fine variety has been named THE PEACOCK because the upper petals of the flower most nearly resemble, in color, the peculiar shade seen only in the feather of the peacock, A BEAUTIFUL ULTRA-MARINE HLUE. The petals are edged with a THIN WHITE LINE, within which is a space of PURPLISH CRIMSON, passing into a rich central blotch of DEEP BLUE, shading to black. The "Gar= deners" Magazine" (London, Eng.) say s: "The coloring is truly delicious" We are sure this most recent and most charming addition to the interesting family of Pansies will be hailed with pleasure by the many admirers of this lovely flower. Pkt., IOc.; 3 pkts., 25c. ECKFORD'S PRIZE PANSY.
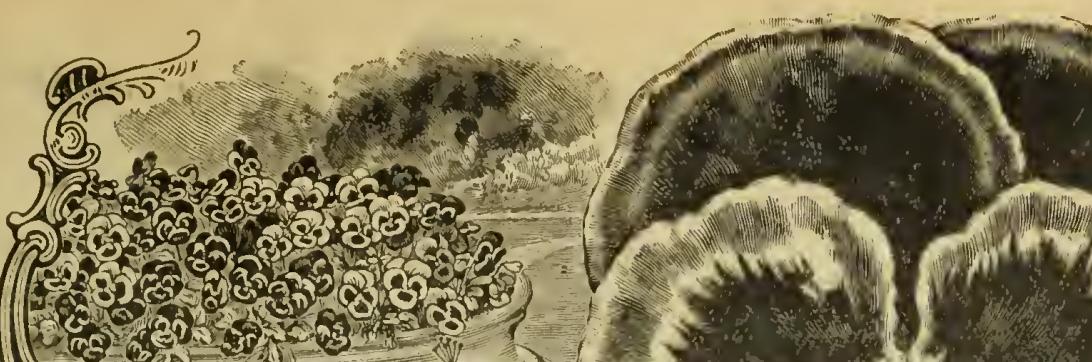

PRIZE PANSY. Mr. Eckford to

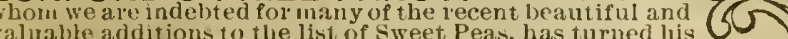
attention to Pansies with equal success. Eakford'- P'rizt Pansy ls a superb cross-fertilized mixture of superior excellence, comprlsing some of the most lovely varieties of this farorite flower. The colors are brllliant and novel, dark violet, gold, blue strlped. blotelied or flushed with red and bronze. It is also recommended for size and beauty of form. Pkt., 20c. GIANT WHITE SPOTTED PANSY.

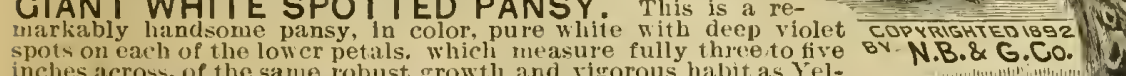

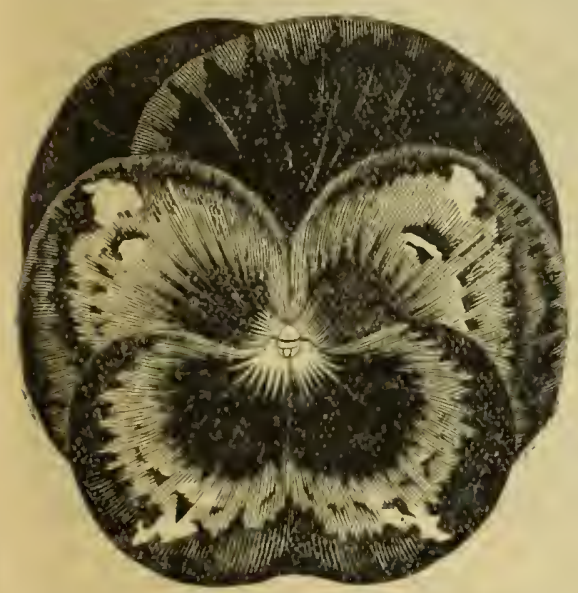

Eckforcl Prize Pansy

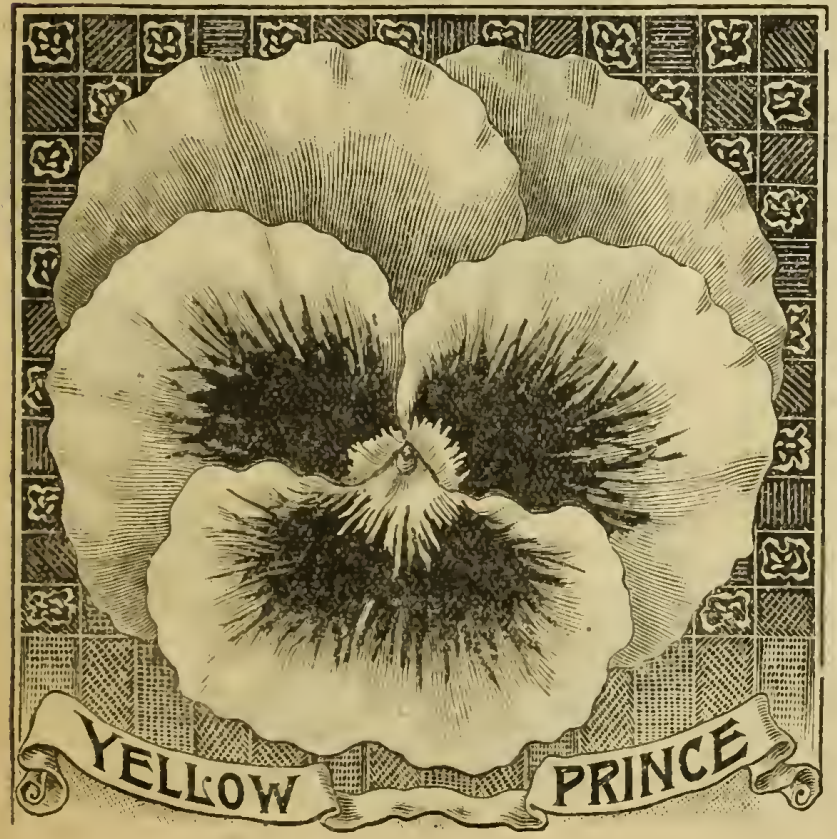

cow friends of the pansy will

be pleased with this new va-

rety, and it will undoubtediy

as the Yellow Prince. Pkt., 10c.; 3 for $25 \mathrm{c}$.

BLACK PRINCE. A distinct pansy

siderably larger in size than king of the

The rich, glossy black has a peculiarly

soft, velvety apprarance hitherto un-

of fine circular form and carried uprlght wel

compact, bushy habit, and flower so pro-

fusely that a bed of the Rlack Pince makes

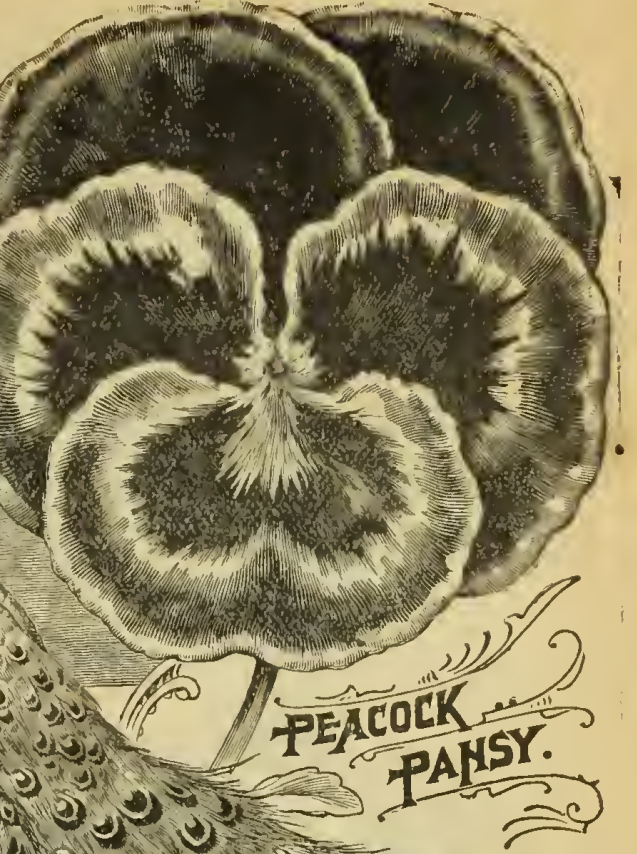
PEACOCK

IMPROVED SNOW QUEEN. Pure satiny white with characteristic yellow dot in center of flowcl, sometimes marked ncar center with faint blue or purple lines, and is especenticlasses, they are yet very highly prized by a great many Pansy lovers for just that reason.

PRINCE. It is impossible to reproduce by means of the printers' art the grand depth of brilliant color presented by this beautiful new Pansy when in full growth conditions: of perfect form and in color. pure golden yellow; with the three lower petals contincons; of perfert form and. in color. pure golden yellow; with the three lower petals re so perfert that it is certain to become in favorite variety and ashy growtll, and free flowering GIANT PANSIES. The Giant. or Trimardean Pansies have been very greatly imploved sinces theil' introduction, some ten or twelve years ago. At that time. although they proved very popular since then by consiant calin the aldization and selection they have been so greatly inproved as to be no longer recognizable under the name of Trimardeau. Not only have they been bettered as regards coloring.

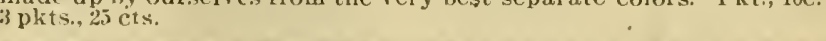

Mrs. L. S. Hoge, of Morris, Ill., writes: "Last spring,
among other things. I got three plants of the Minneapolis
Climber. They grew to be very, very handsome vines."
Jennie O. Dye, Boston, Erie Co., N. Y., wites: "I gut
Your Snowball and Fire King Asters were grand. No one
can describe them in words and do them justice. They were
the handsomest I ever saw."
Peter Nelson, of Alhia, lowa, writes: "The Seeds pur-
chased of you pleased me very highly. A finer flower bed
pecially pleased with the Sweet Mignonette, which was
very fragrant." 


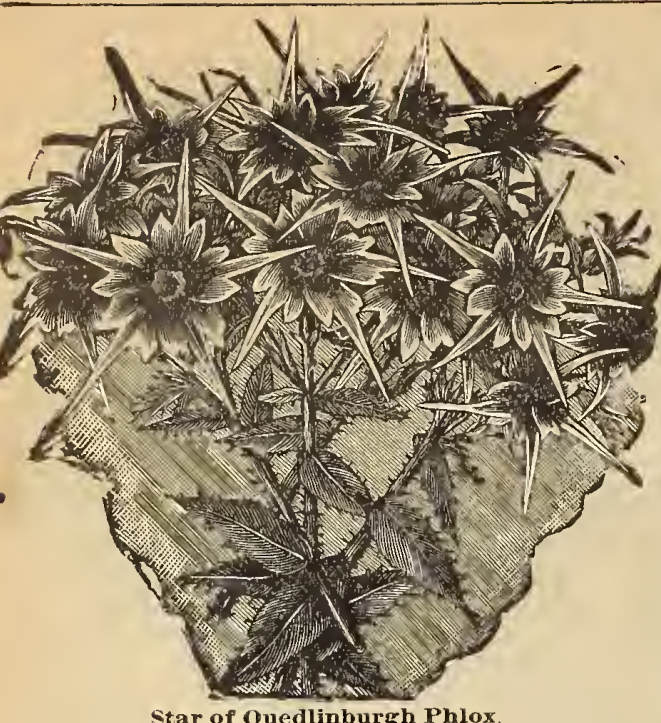

Star of Quedlinburgh Phlox.

MNA S

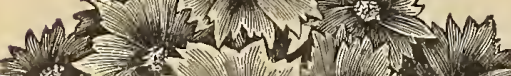

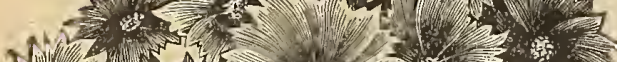
Int (5) 3.1.

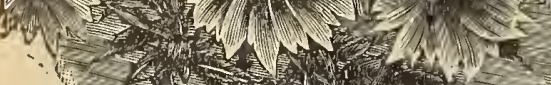

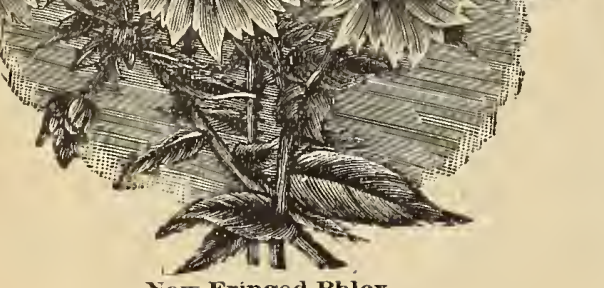

New Fringed Phlox.

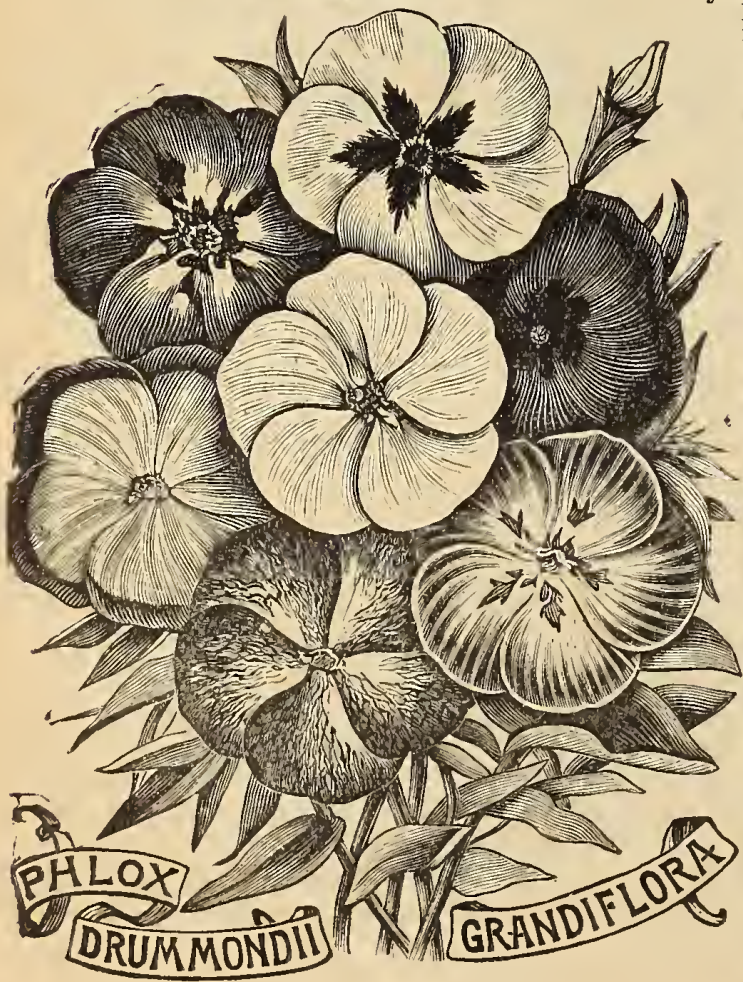

PHLOX, Star of Quedlinextraordinary character. The growth is dwarf, and the habit very compact. The pointed in number) are four or five

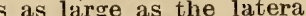
ones and project beyond them
like little spines. The flowers appear to have a star-like form, effect. Finest mixture of o ver PHLOX. New Fringed. The New Fringed Phlox, the compurg," is not only unique in shape, but of great beauty, con-
sisting of more than twenty distinct shades, while many of the flowers are as large as the tinct variety and partly three-toothed, all distinctly together with the bright eye of the center, picturesquely conrast with the magniticent velPhlox Drummondii Grandiflora. N. B. G. Co.'s Superb Mixed. A magnificent class with flowers large as those of the Perennial
Phloxes. The colors we offer in our "Superb Mixture" are very positive and perfectly Their long duration in bloom. combined with their almost col richness of color rendics them of invaluable For massing in groups or arranging in ribbon lines, there little care and expense, the
colorsranging in every conceivable shade. Plkt. 10c: 3 for $25 \mathrm{c}$.
Our mixture of the above cannot be surpassed. This is an entirely new sort and only recently offered. From a idere clescilption no adequate by a bed or mass when the plants are in full bloom, the eye and perfectly resembling the well known Scarlet Duc Van Thol or Vermilion Tulip. in June and flowers abundantly for a period of 6 to 8 weeks. in color and broadly pinnate or lobed. The plant inches a helght of 12 to 1 above the foliage 50 to 60 large and splendid flowers inaginable. When the floweirs begin to fade two black spots appear at the base of THE SHIRLEY POPPY.

It is perfectly hardy, and flowers the firstseason from exceedingly graceful and soft and varied, and rang
from bluish white, rose delicate pink and carmine
tlirough innumerable tints " "WHITE SWAN", POPPY The plant grows from $1 \frac{1}{2}$ t 2 feethigh, forming a dense
richly branching bush above which are elevated very large flowers
b!ossoms are of fibulous
size, very double, laciniated
and fringed, beautifully and fringed, beautifully
shaped and of the purest
snow white. Packet, $10 \mathrm{cts}$ : Gackets, $25 \mathrm{cts}$. White Poppy Great California White Poppy
A fine perennial varlety of
treat beauty, resembling 1arge single white Preonies,
both in foliage and fowers. The flowers are 4 to 5 inches
ar: rocs. The plant is 6 to 8 areross. The plant is 6
feet high. Pkt., 10 cts.

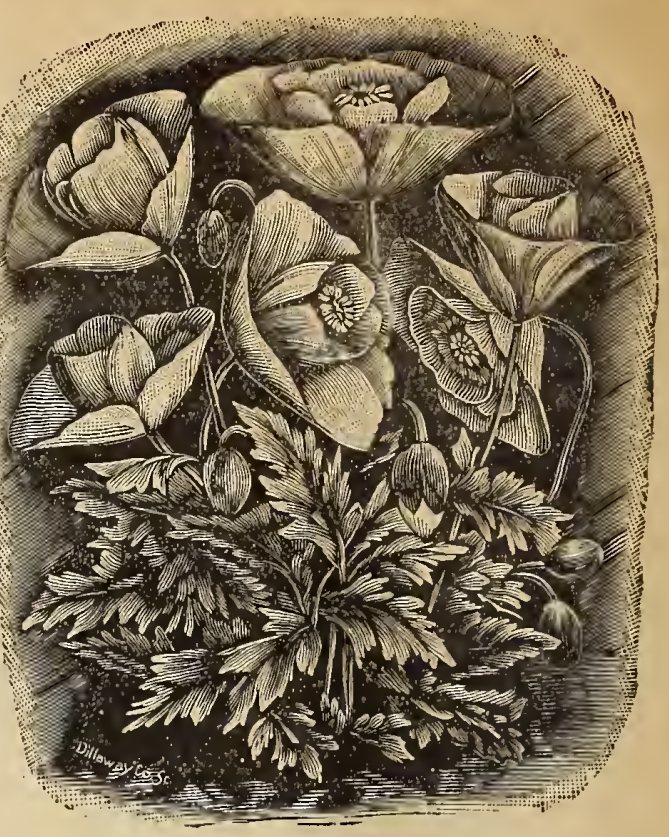

Tulip Poppy.

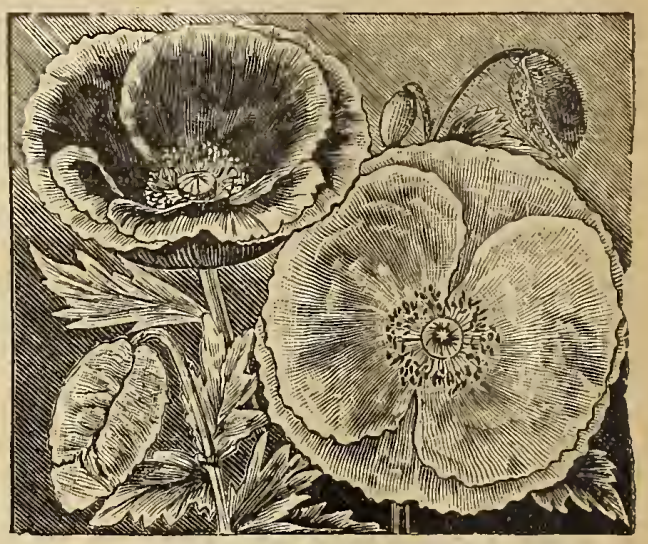

Shirley Poppy.

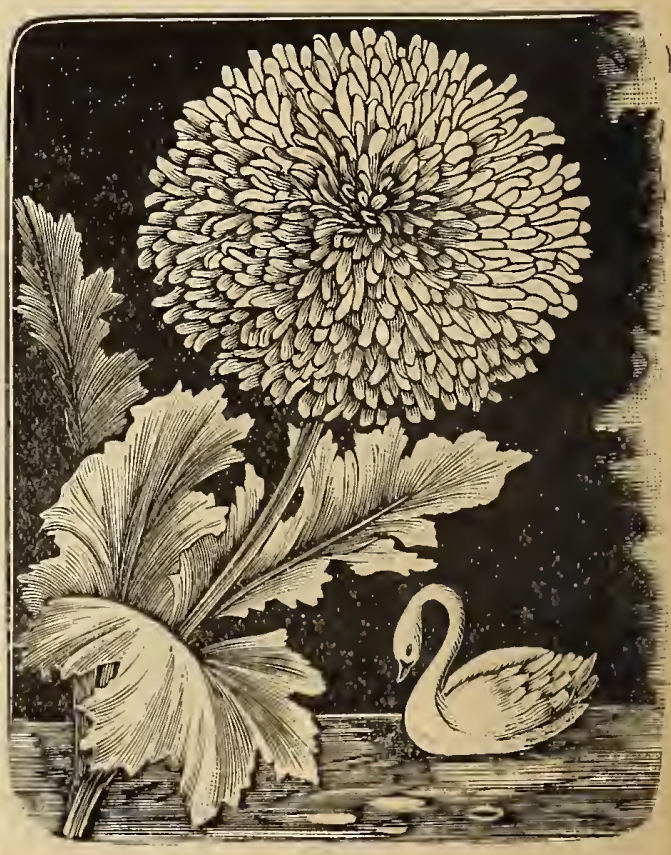

White swan Poppy. 
72 SWEET PEAS.-N. B. G. Co.'s Imperial German. Choice Named Varieties.

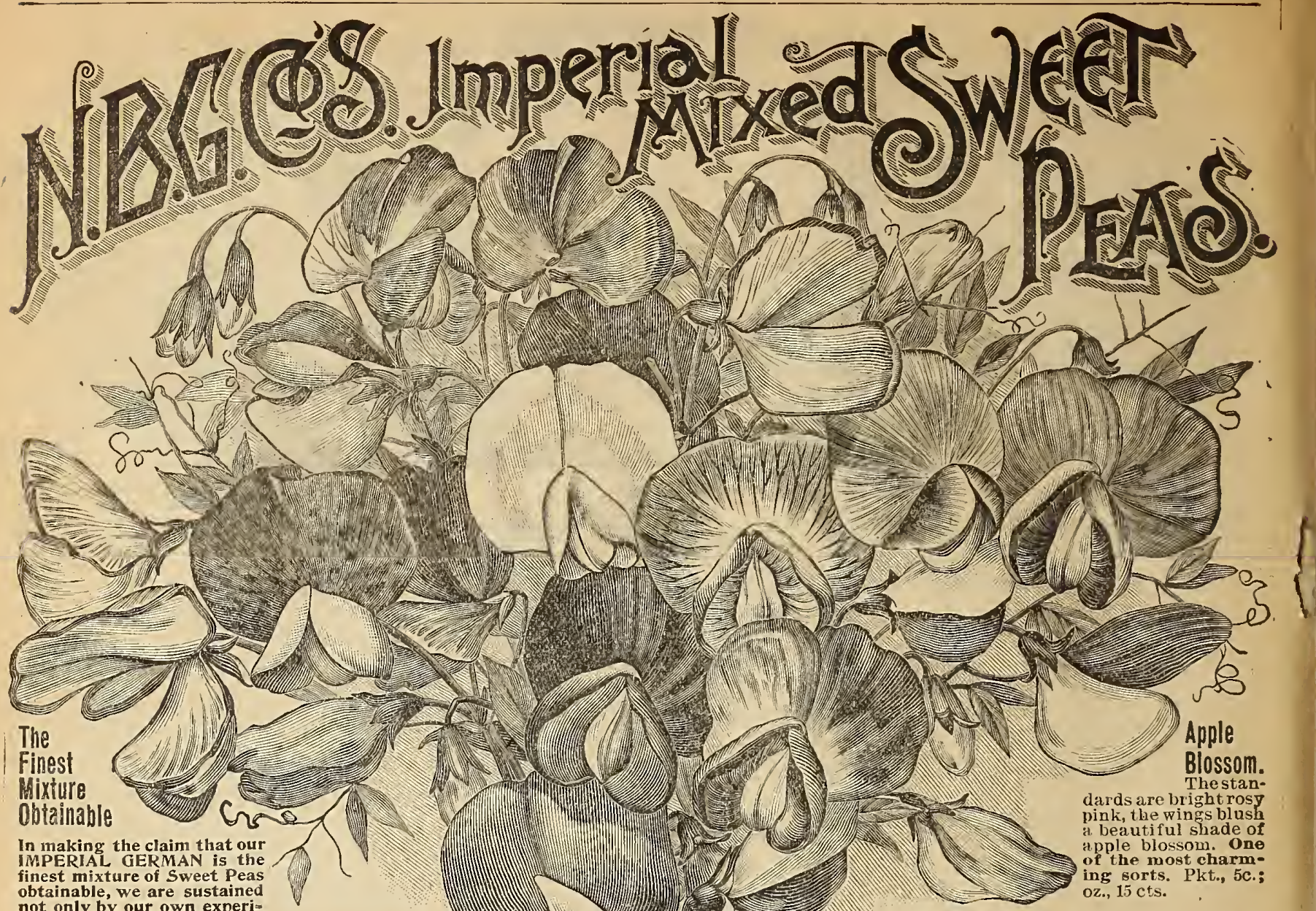

not

not only by whe

ence, but by the testimony of customers who

have bought this Mixture for years. With old

patrons no recommendation is necessary. To

those who have never used this special mixture

grown, you should give the IMPERIAL MIXED a trial, and be convinced of their wonderful beauty; the flowers are of large size, and in colors surpass any other mixture of
known to us, being rich and gorgeous, ranging from bright known to us, being rich and gorgeous, ranging from bright
scarlet, carmine, maroon, rosy pink, purple, indigo blue, scarlet, carmine, maroon, rosy pink, purple, indigo blue,
pure white, black, striped, laced and shaded, many of them soft and charming shades, suffused with an entirely differsoft and charming shades, sufused with an entirely differ

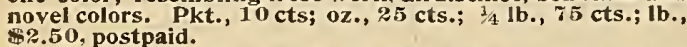
N.B. G. C.CO.'S GOOD MIXED.

Those living in cities or large towns can often add acceptably to their pocket money by making up, each morning, a stores. We know of one lady who received over FORTY DOLLARS in this way, from a
Sweet Peas, forty feet in length.

SWEET PEAS IN SEPARATE COLORS. MISS BLANCHE FERRY.

perfect forme, which possess deeper, riclier folluring

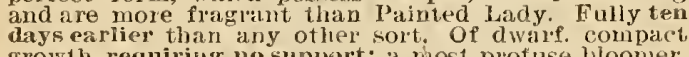

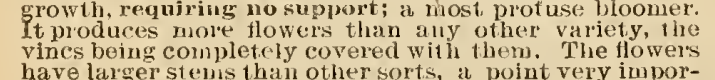

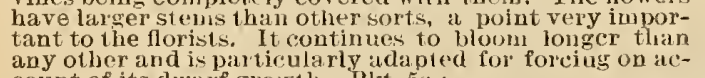
BOREATTON. cribur winc of beustiful crimsont purple, shaded with rose. A distinct
and beautifut sort. The darkest
sort in cultivation. Plt. Sc.; Oz. 15e. DUCHESS OF EDINBURGH.

splashed with crimson, edge crean

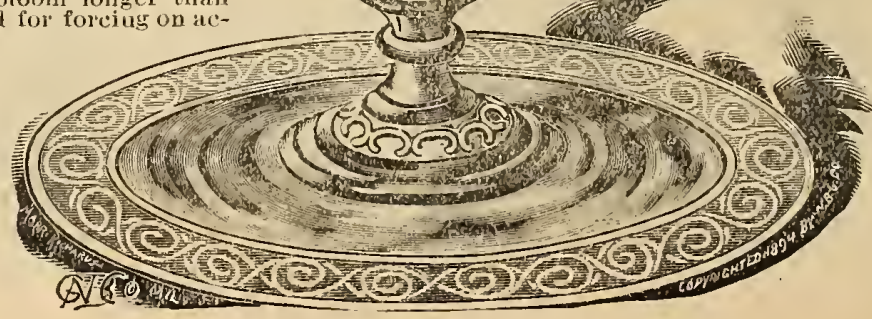

SPLENDOR. Flowers very large; The most brilliant red sort. Pkt., $10 \mathrm{cts}$. PRINCESS OF WALES. A verr 010
very large, of great substance and perfect form. Non Nand Nen 2. $N(1)$ EMILY HENDERSON. This grand new varlety originated as a sport in a tity which has given the Blanche Ferry its distinetive valte, has been re. produced in the Emily henderis pule as the nriven snow It

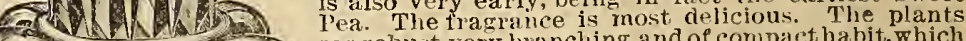

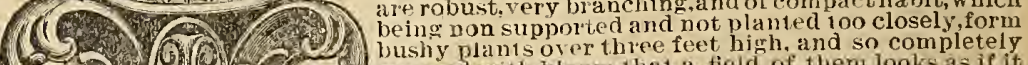
3) (C) (c)

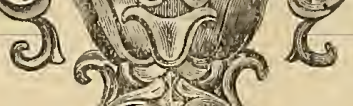

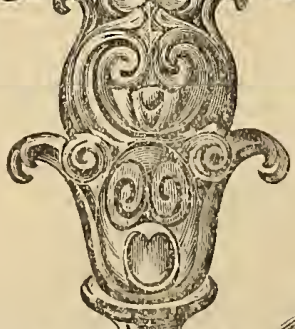

INDIGO KING. Dark nimoon purple with inMRS. SANKEY. Nex. The flowers of this grand purte white variety are of enorrous size and GRAND BLUE. (Imperial Bane) The wings

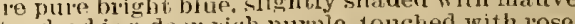
standind is al derprich purple, touched with rose A very halldone and effective variety. The best blue ORANGE PRINCE. Brighit orange-pink. flushed carlet, wings bricht rose, QUEEN OF ENGLAND. whice, wings rose tipued

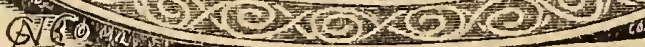
QUEEN OF THE ISLES. A very Landsome sort. The large flowers are scarlet, mottled
and flaked with white and purple. PIKA 10c. 
VERBENA, VIOLET, SWEET WILLIAM, ZINNIA, STOCK.

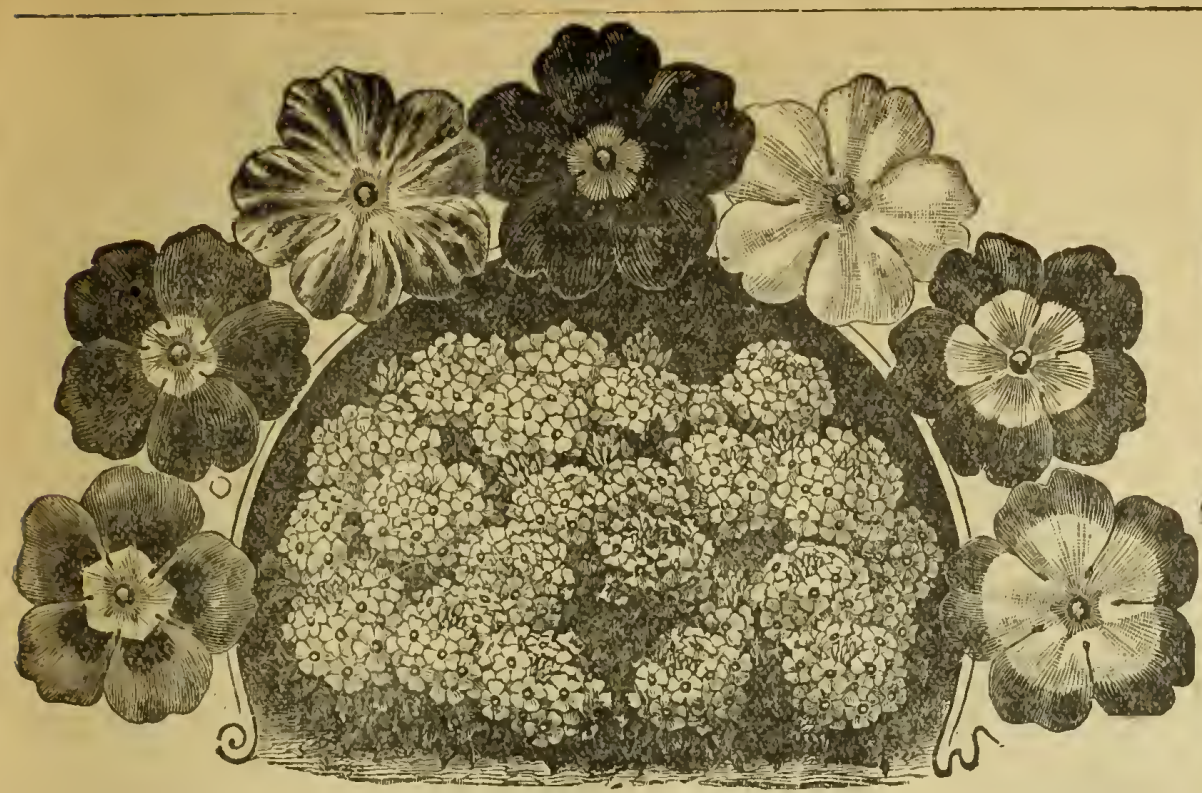

Verbena, Mammoth Flowering.

VERBENA. Large llowering Maumoth. If the Rose is the queen of flowers, the Verbena is certainly a princess in the royal fantlily. The purest, nost vivid color borne by any petal ts the eye." The presence of this flower in the garden, therefore, is a desirable accession of sunny color, like a "stained window in a clinch." The flowers of the New Mammoth are of gigantie while the clusters of bloom are niagniticent and the range of color more varied than in any ot her mixt ure. Without donlt this is the finest and best cuttlngs, and tio plantistence. Yerbenas in quant tity arr more easily obtained from seed than gated from cuttings. Hence the labor and cost of the old method of obtaining in supply of

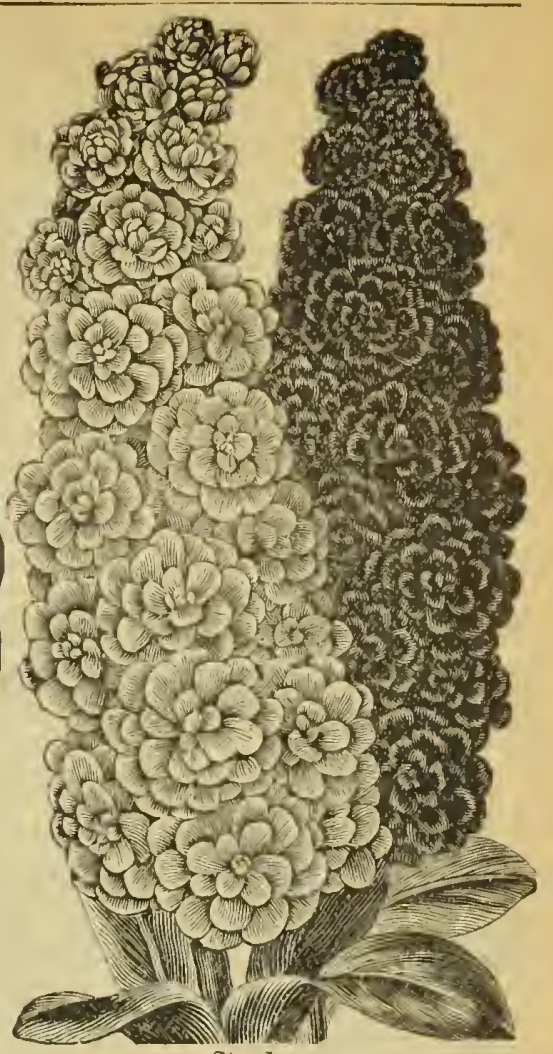
have plenty of brilliant flowers untit kilfed by rost. Packet, $S T O C K S$, TEN WEEKS.

VERBENA HYBRIDA. (Importedsed.) Fine mixed. Pkt.

VIOLET

( and can be easily incte sivest

SWEET WILLIAM. Dianthus Barbatus. Matcliless as border plants; flowers of nany briglit color's and varied markings, including the fines

ZINNIAS.

ZINNIAS. giant in slze and perfectly double flower's of richest and most varied a long period. making it particularly valuable for large group. choicest Hixcd.jets.

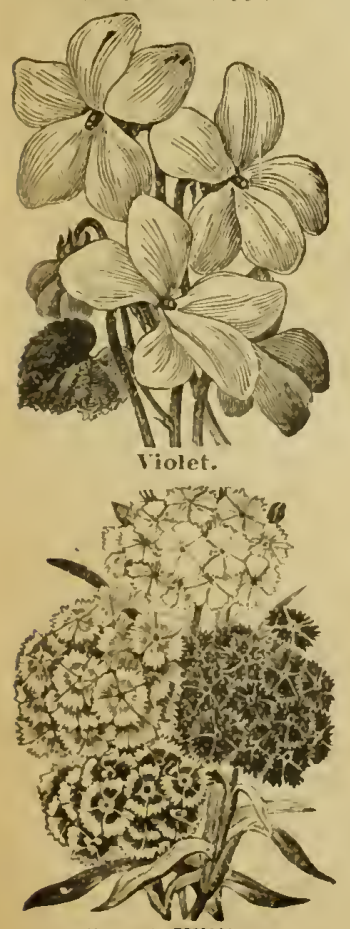

(Dianthus tharliatus.)
STOCKS, TEN WEEKS. New Largest Flowering Glohe in shape, the individual blooms frequently measuring from 2 to $21 / 2$ EVENING SCENTED STOCK.

No annual in cultivaperfume of its flowers. The pink and lilac blossonis are partially evening. It should be sown from March to June in any good garden
soil. Our friends may be very sure this will give them every satisLEMON VERBENA. The botanical nane of this variety is Aloysia, named in honor of Maria Louisa, Queen of Spain. It is 


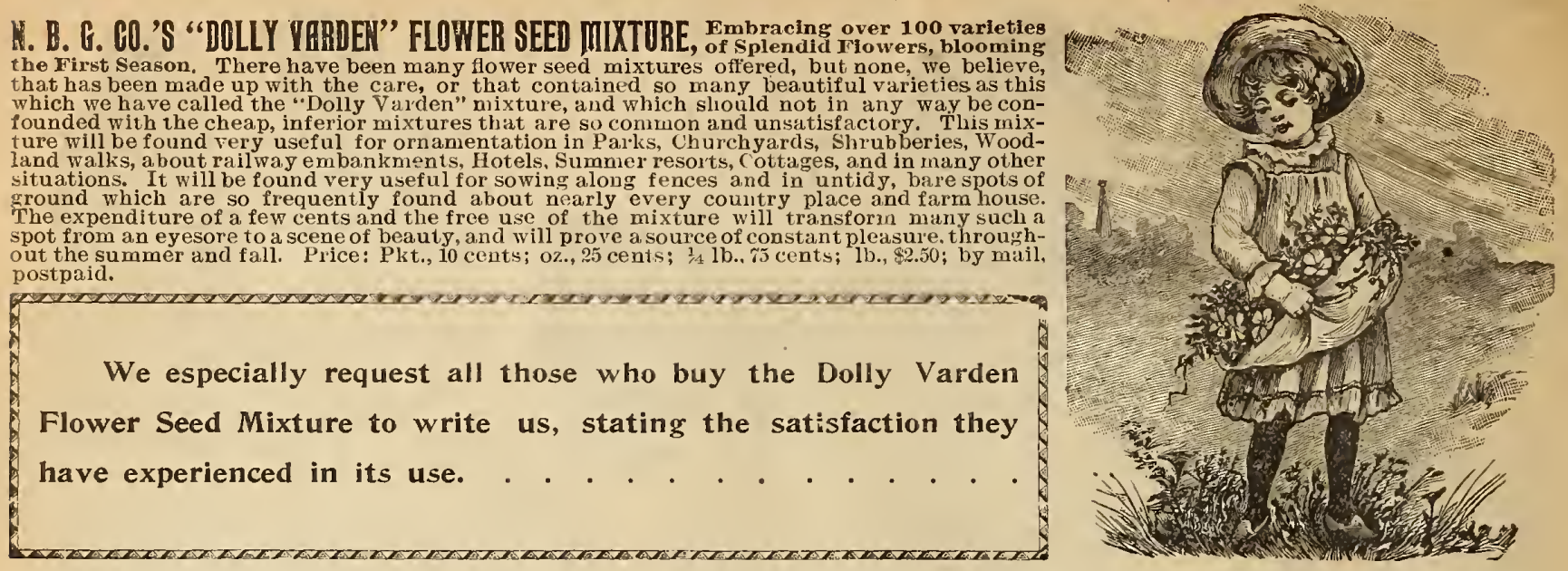

\section{EVERLASTING FLOWERS}

are a treasure in the winter, when it is desirable to decorate church, school-room or home. Retain form and color for years. Our own mixture of the fol-
lowing five sorts, including other desirable varieties. Large pkt., $10 \mathrm{c}$, 3 pkts., $25 \mathrm{c}$.

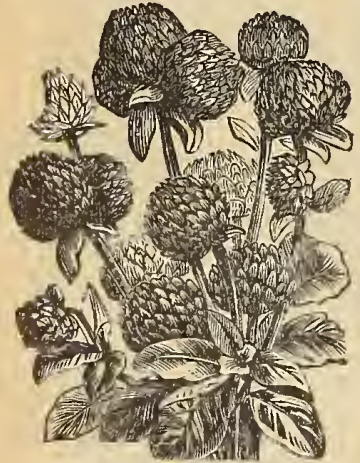

GLOBE AMARANTH.

Gomphrena.

Valued for its handsome, globular heads of thowers, tored, will retain their beanty for years. Mixed Colors.

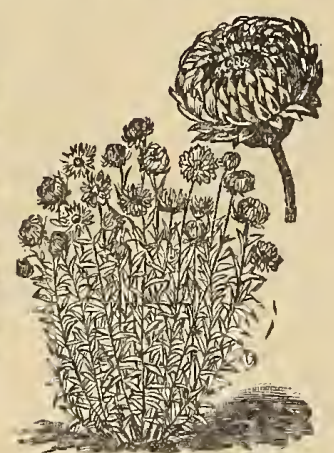

ACROCLINIUN.
Everlasting. Everlasting.

hiche are "Immortelles" Large, fuli, double flowers of Theom in August and various colors, from bright

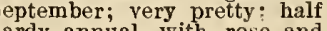
white daisy-like flowers.

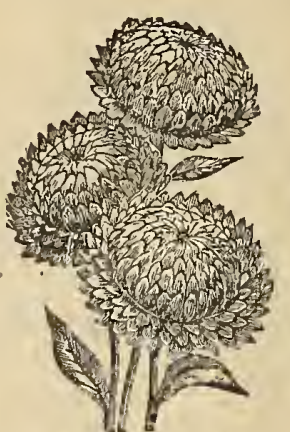

HELICHRYSUM

The flowers are of various yellow to scarlet; shaded and colors, pure silvery white with tipped. The most beautiful bright purple, etc. Tender
of the everlastings. Mixed. annual everlasting. Mixed. Pkt, 5 cts.

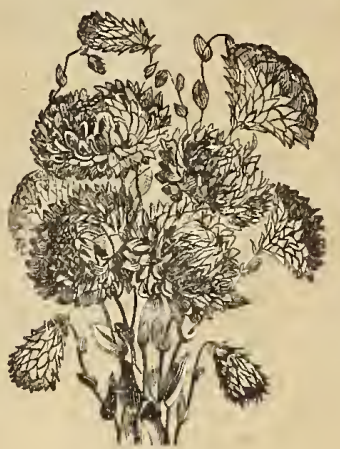

RHODANTHE.

Everlasting. are not only pleasing and attractive to the flower garden, but also indispensable
for winter bonquets, if cut while green and dried in the shade. To induce our customers to plant them nore largely, we have prepared a mixture of the ORNAMENTAL GRASSES

\section{ARUNDO DONAX.}

Variegatus Aureus.

Golden yellow, striped leaves; grows six feet high
perennial. Pkt., $5 \mathrm{cts}$.

\section{BRIZA MAXIMA.}

Quaking Grass.

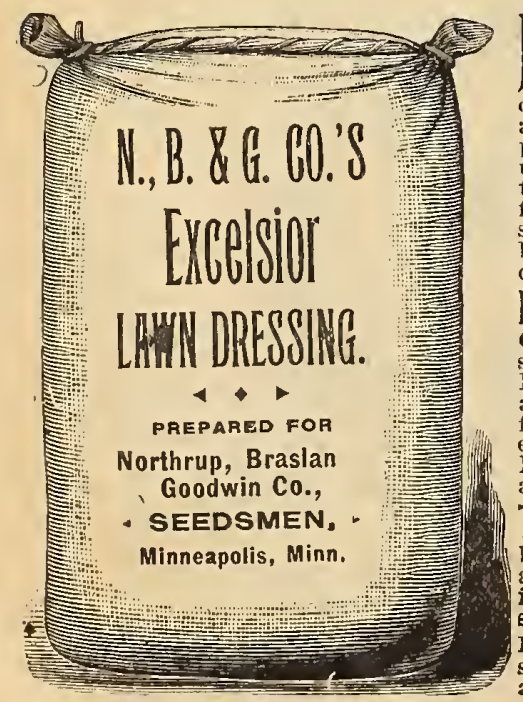

\section{COIX LACHRYMA.}

Job's Tears.

Broad, corn-like leaves; curious ornamental grase from
the East Indies; hardy annual. the East Ind
Pkt., 5 cts.
GYNERIUM.

Produces elegant silver
HORDEUM JUBATUM.

Squirrel Tail Grass.

Squirrel Tail Grass. plumes 18 to 20 inches in ley, having heavy bearded length; very beantifn!; half heads. It is very hardy. Pkt., hardy perennial. Pkt., ioc. 5 cts.

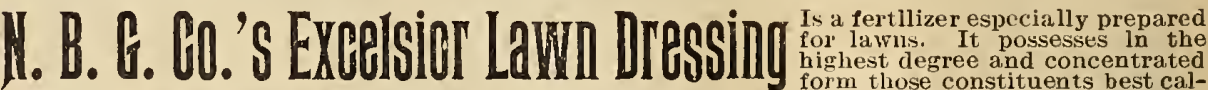
admired. It is not only the, promote ics luxuriant grow b, and sie dark green color so greatly pleasint to landle, being non-odorous, so that its liberal use on a lawn cannot be detected by any ampleasant odor. Being d'y and tine it is very easy to apply, and imparts such a vlgorous growth to the grass that two or three applications during the season at the rate of one pound to each 100 square feet of lawn keeps the grass in flourishing condition throughout the season, and enables it to withstand the effec't of the hot summer sun. We prepare but gae kind of Lawn Dressing. This we do not believe can be excelled. It is put up only in bags containing our brand. By express or frelght, bag How to foply the Excelsior LaWn Bressing. The first application should be made early in the Care should be taken to scarter it evenly over the lawn, sowing it hy hand. The first application should be inade at the rate of 10 to 15 pounds of fertilizer to every 1.000 sfuare feet of lawn surface. If at any tine af terwards it be noticed that the lib $n$ is thin and limht colored in spots, a further application of firetilizer will speedily restore its color. The fertilizer works best if applied just before a rain. If applied, however, when the weather is hot and dry, the application should be made arly in the morning or late in the evening, and the lawn wet down freely immediately afterwards. In seeding down a new litw a pply, broarleast, double the anount of lel'tilizer above mentloned. in thoroughly bufore sowing the seed,

The Use of Excelsior Lawn Dressing on Flowers. By its judicious use the health, vigor and be be greatly enhanced. The result of its use on flower beds is quickly seen by the dark green leaves ing to the size of the plant, in to the soil about each plant, and repeat two or three times during the ing to the size of the plant, into the soil about each plant, and
season. After the Fertilizer is used, water the plants freely.

FOR HOUSt: PLANTS dissolve one teaspoonful of Fertilizer ln one quart of water, and use the solution freely around the plants, stirring the solution while appiying. $1 \mathrm{t}$ may be applied as often as the plants seem to require it; once every week or ten days until they are in the desired condition. 


\section{OUR FLㅇWER SEED CoLLECTIONS}

(For Vegetable Collection see page 37.) We are able to offer especially liberal terms on collections, owing to the

fact that they are put up in large quantities and made ready for sending out before our heavy trade opens. They have also served to introduce our seeds favorably to thousands of flower lovers.

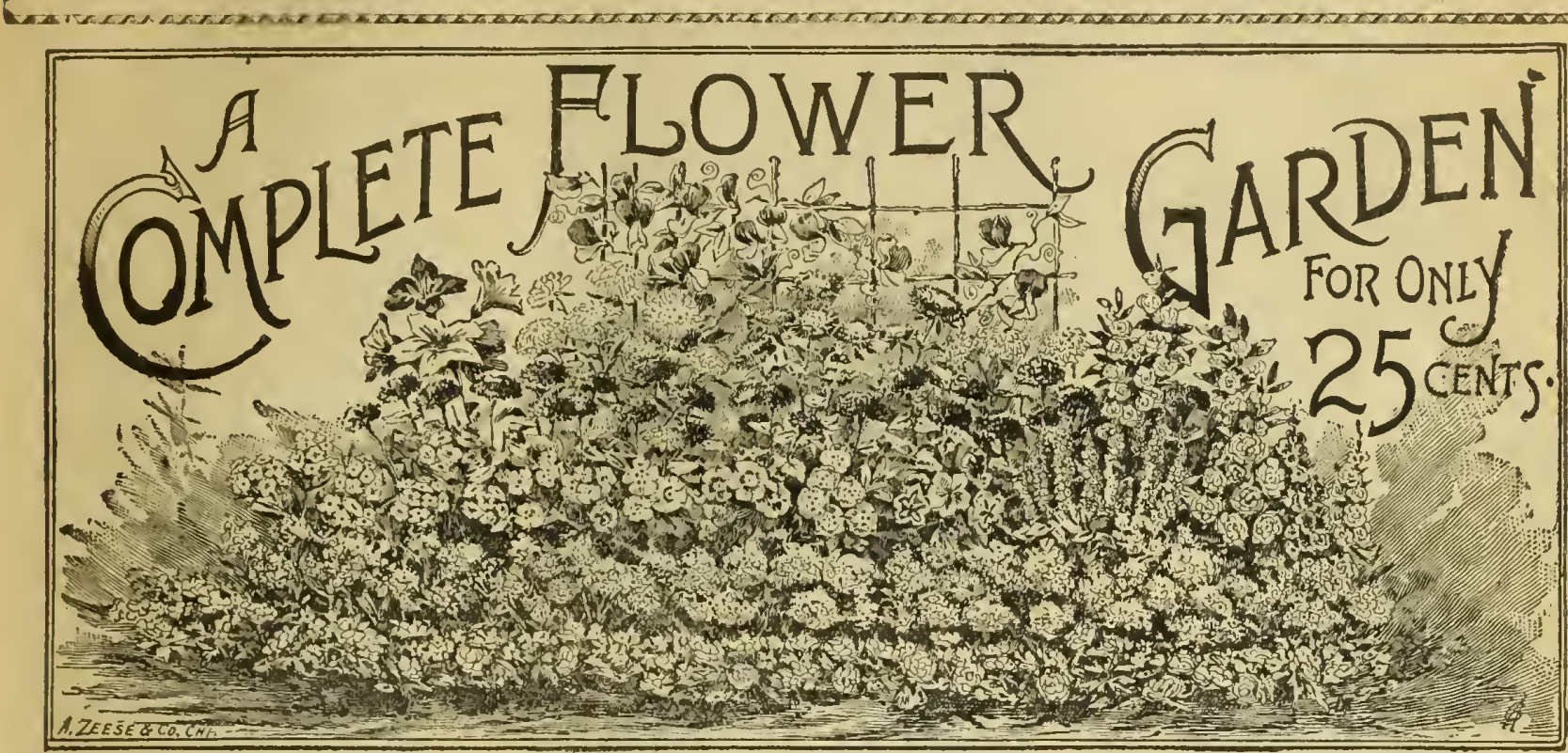

$\frac{7}{2}$

$7 \mathrm{O}$ meet the demands of those who wish a neat display of Flowers at a small expenditure, we have selected twelve of the most beautiful and showy annuals, that will bloom the first year, from which the effect shown in the above illustration can be produced. This flower seed collection, comprising twelve choice sorts, viz: Portulaca, Sweet Alyssum, Verbena Hybrida Mixed, Sweet Mignonette, Phlox Drummondii, Ten Weeks Stocks, Petunia Hybrida, Zinnia, choice mixed; Aster, German Quilled; Balsam,Camelia Flowered; Salpiglossis, best mixed, and Sweet Peas, good mixed, will be mailed free to any address for 25 cents; five collections for $\$ 1.00$. We have sold this same collection for three years and have received hundreds of letters expressing the wide satisfaction it has afforded.

N. B. CO'S 50 C FLOWER SEED COLLECTION. The great success we have experienced with our 25 cent flower collection has encouraged us to form another group of varieties that will bloom the same season they are sown. It will be observed that this collection embraces the very cream of the flower seeds we list, and we feel perfectly warranted in saying, that never before has such real value in flower seeds been offered for so small a sum. We are aware that such an offer really diminishes our receipts for the time being, but we know that it will prove a favorable introduction of our seeds into those gardens where they have not yet been used. This collection, made up of one packet each of the following varieties will be mailed to any address on receipt of 50 cents; seven collections for $\$ \mathbf{3 . 0 0}$.

It will be noted that at our regular catalogue prices these seeds would cost the purchaser \$1.35. The packages are the same in size and all other respects as if purchased outside the collection.

1 pkt. Aster, N. B. G. Co.'s Imperial

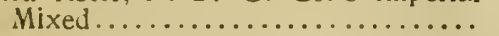
1 pkt. Balsam, N. B. G. Co.'s Imperial Mixed..................... 15

1 pkt. Carnations, Dwarf Margaret...... 10 pkt. Chrysanthemum, N. B. G. Co.'s Imperial Mixed................ 10

1 pkt. Mignonette, Machet........... 5

1 pkt. Petunia, Double, Large Flowering, Nixed....

1 pkt. Pansy, Goodwin's Imperial Ger man.................

1 pkt. Phlox, All Varieties Mixed....... 10

1 pkt. Sweet Peas, N. B. G. Co.'s 1mperial Mixed................. 10

1 pkt. Verbena, Mammoth Flowered.... 15

1 pkt. Zinnias, Mammoth Mixed....... 10

\section{5}

\section{5} 5 
HE CULTIVATION of Summer Flowering Bulbs is steadily increasing year by year, for the reason that their culture is easier and simpler than from seed, as they require less care in starting,grow rapidly, and Flower the first Summer, and bloom and multiply season after season. They are moreover, so beautiful, so bright, graceful and fragrant. that they are now considered indispensable by plant lovers for pot culture in parlor or conservatory, and for outdoor decoration.
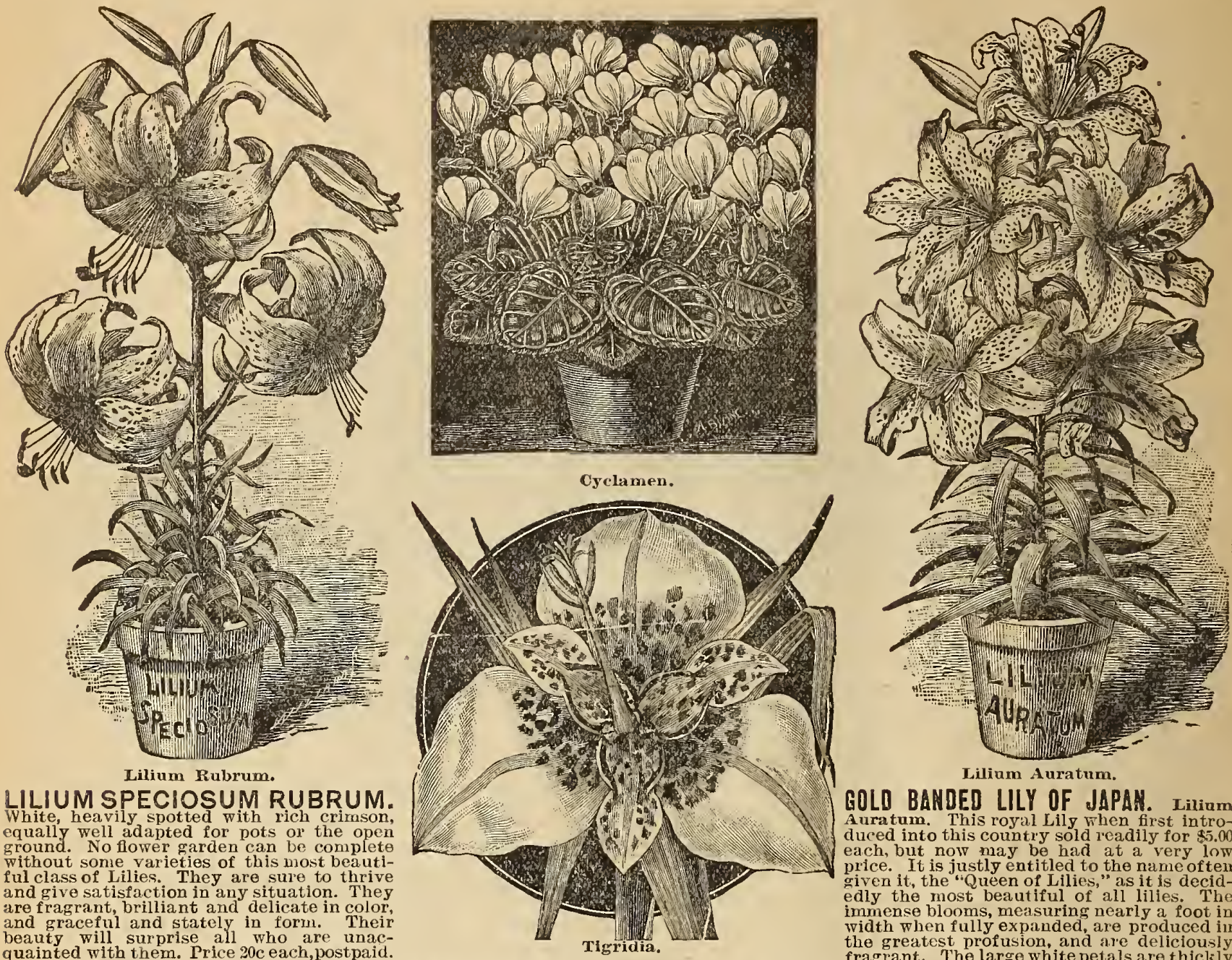

LILIUM SPECIOSUM RUBRUM. White heavily spotted with rich equally well adapted for pots or the open wround. No flower garden can be complete ful class of Lilies. They are sure to thrive and give satisfaction in any situation. They and graceful and stately in form. Their beauty will surprise all who are unacCYCLAMENS. Certainly most interesting and beautiful win-
ter and spring flowering bulbs. Not only are the flowers of striking beauty, but the foliage is also highly ornamental being handsonely marked with various shades of green, gray and white. The sorts
offered here are considered hardy, and would. no doubt, prove so in ony but the coldest locality,
ant it would seem wasteful to
but plant them out, when their ex-
treme beauty can be employed indoors durting summer and
winter. They bcrin to bloon as soon as planted, and then produce their fine foliage in
abundance. The bulbs are excellent kcepers. 1'emaining solWhen not planted. Hardy in the garden, if planted
4 inches deep. Rosy pink tlowers in autumn; beautiful fol-
age. $25 \mathrm{c}$ each; three for $60 \mathrm{c}$. CYCLAMEN NEAPOLITANUPI. Hardy and charming species;
leaves finely variegated, flowleaves finely variegated, flow-
ers white and roso with purple throat: blooms in September
or October. 25c each; 3 for 600 . CYCLAMEN REPANDUM. Early spring flowering; deep reddish crimson; leaves marked white;

each; 3 for 60 cts. Cyclamens for 50c, postpaid.

Gussie Arnold, Brewton. Ala., writes: "I had the loveliest seen, grown from your seeds."

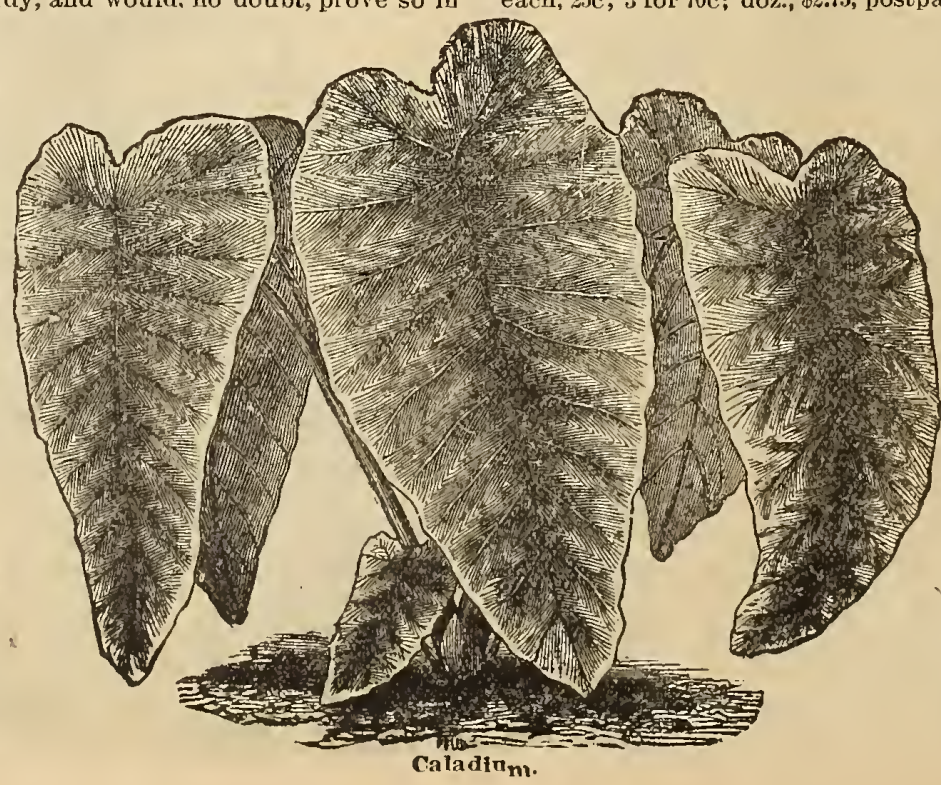

GOLD BANDED LILY OF JAPAR. Lilium Auratum. This royal Lily when first introduced into this country sold readily for $\$ 5.00$ price. It is justly entitled to the name often given it, the "Queen of Lilies," as it is decidedly the most beautiful of all lilies. The immense blooms, measuring nearly a foot in width when fully expinded, are produced in the greatest profusion, and are celiciously
fragrant. The large white petals are thickily spotterl with rich chocolate band through the center of each. The plants sometimes produce a. (1) This magnificent plant for $\$ 1.25$; doz., $\$ 4.50$ postpaid. TIGRIDIA GRANDIFLORA ALBA. Its flowers a re lurge, of a clear. pearly white color, marked at the base of each dirision with largo spots of a reddish brown on a yellowish ground, forming petal. 7c each; 4 for 25 c, postp'd. TIGRIDIA CONCHIFLORA. FINA yellow, spottcd crimson. ic $^{-}$ TIGRIDIA GRANDIFLORA. Very liarge, bright crimson, center variegated with yellow. $i \mathrm{cts}$. One Bumb of each variety for $18 \mathrm{c}$, or 6 bulbs of each variety for $\$ 1.00$, postpaid.

\section{CALADIUM ESCULENTUM.}

(Elephants' Ears.) These showy plants are a splendic They are among the largest of ornamental foliage plants: grow in any garden soil, and when full size stand 4 to 5 feet high, with immense leaves of ten measuring 4 feet in length bulbs, $50 \mathrm{c}$ each: first size bulbs $40 \mathrm{c}$ each; second size bulbs, $20 \mathrm{c}$ each; postpald. 
TUBFROSE, GIANT FAIRY LILY, CALLA LILY, LILY OF THE VALLEY, GLOXINIA.

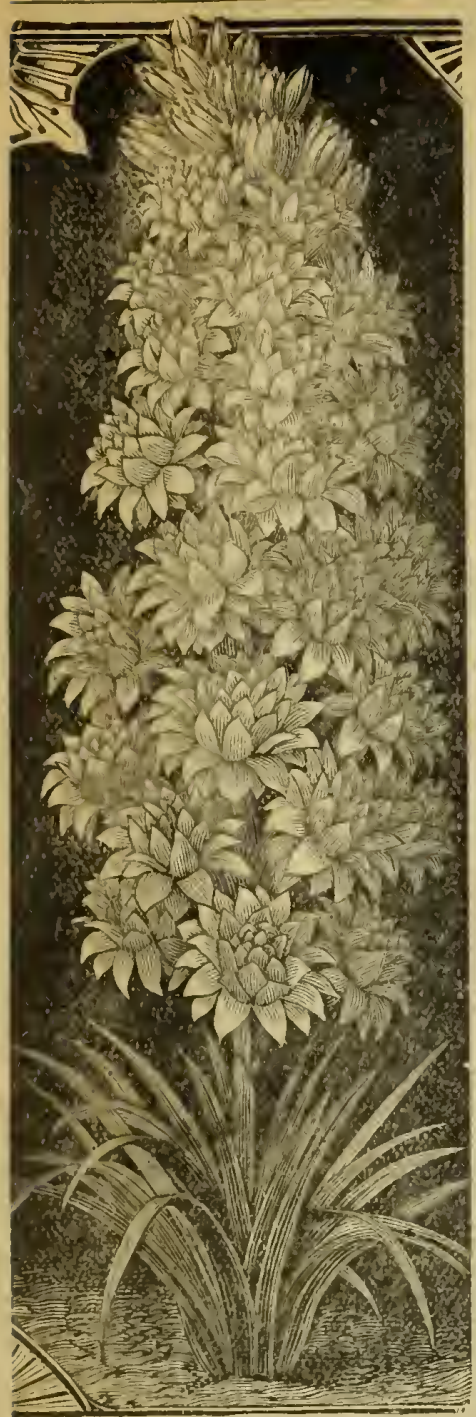

\section{TUBEROSES.}

The Tuberose is pre-eminently a plant for pra. grant that a few "pips" will periume a room, or a single plant a greenhouse, but eops supply of of valt in furnishing a coners, or for ladies' blooms tor bouquet, coat llowers, or for ladies hair. The "pips" may be taken off as they expand, and as they do this gradually
plants will provide for a long period.

EXCELSIOR PEABL. TUBEROSE.

EXCLSIOR PEARL TUBEROSE, An improv-

lieary spikes of larger

press, at purchaser's expense, $\$ 2,50$ per 100.

VARIEGATEO LEAVFI TUBEROSE. The leaves

of this varicty are bordered with creany
white: flowers single but very liarge and of exyuisite fragrance. Bulbs continue to grow

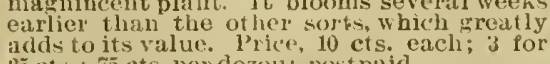

THE GIANT FAIRY LILY, (Cooperia Drummondii.) This is a member of the $A$ ularyllis
fantily, the bulbs being as liurge and solid as a nedium sized onion, and should he planted in the spring, either in the open ground or in
pots (they do as well one way as the other)

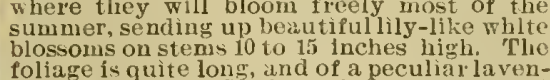
foliage is quite lon and of a pecular laven-

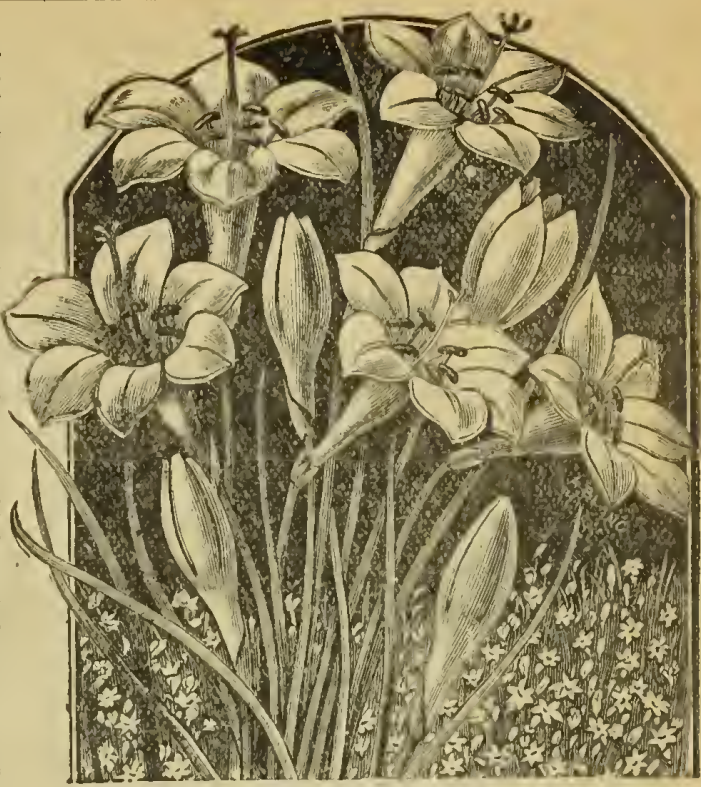
be lifterl and kept diy over winter, like gladiol us. It

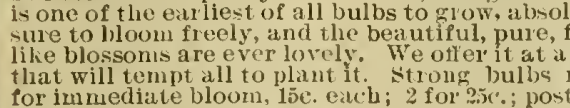
GALLA, OR LILY OF THE HILE. Richardia EthiopCalla. We offer dry bulbs, as they are superior for into bioom quickly and require less room-making pots that have becen licpt glowing or only semi-dol-
mant. Price of Dry isubs-first size, $25 \mathrm{c}$; ; post paid. DWAKF GALLA, "UITTLE GEM."

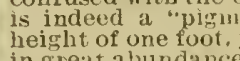

\section{GLOXINIAS.}

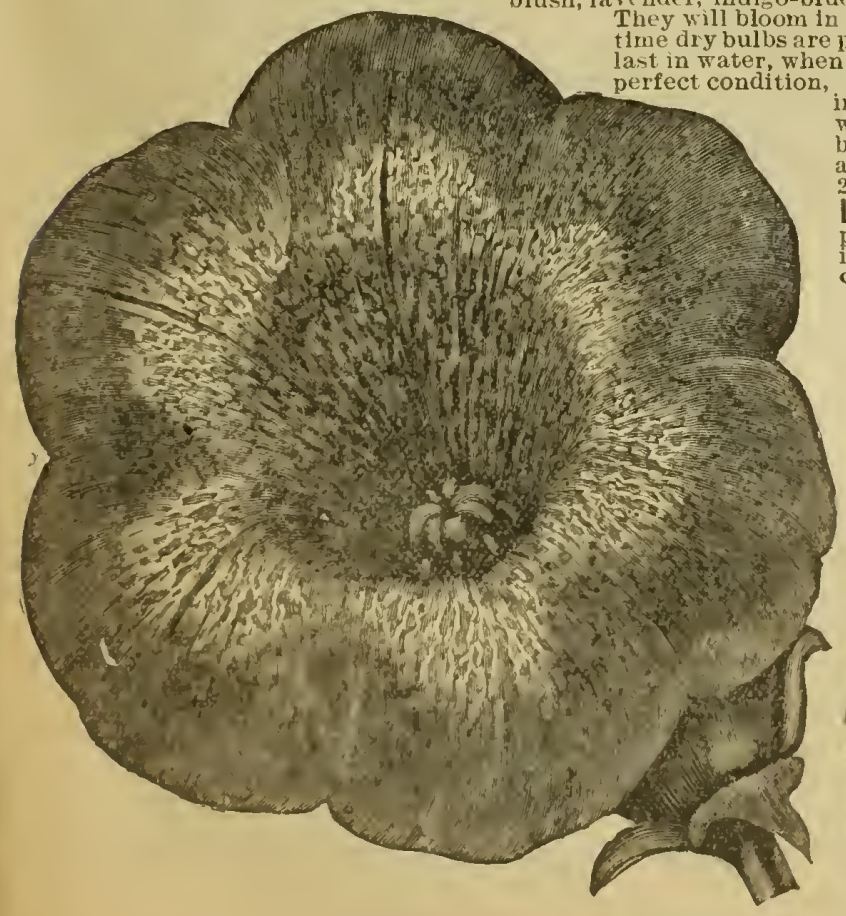

with each order, Strong

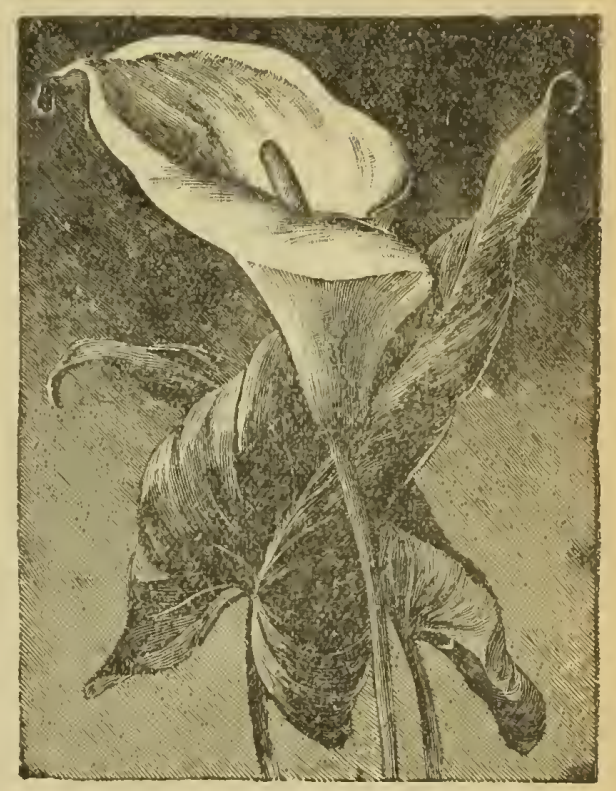

Calla Lily.

LILY OF THE VALLEY. For Winter or spring Blooming. The pins ing. Six for $25 \mathrm{c}$. 12 for $40 \mathrm{c}$; 100 for $\$ 2.00$; postpaid. Write for special prices $m=1$

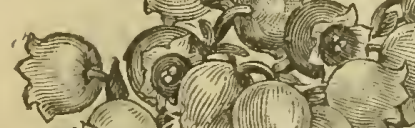

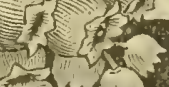

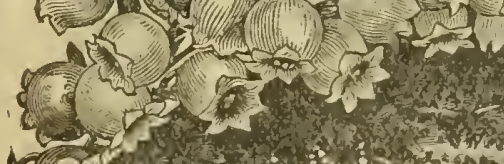

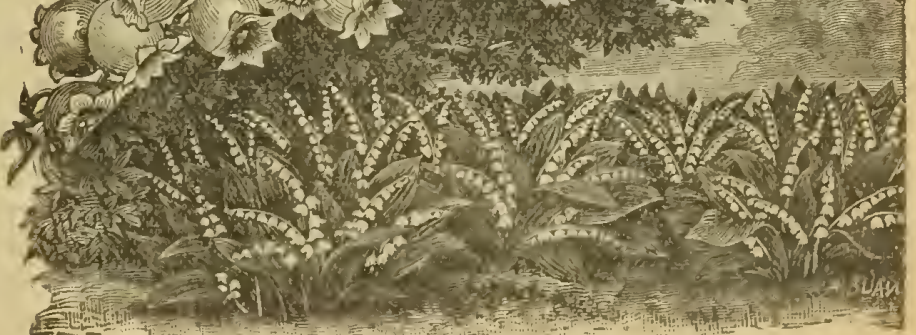


GLADIOLI. TUBEROUS=ROOTED BEGONIAS.

\section{The Most Satisfactory of all Summer Flowering Bulbs.}

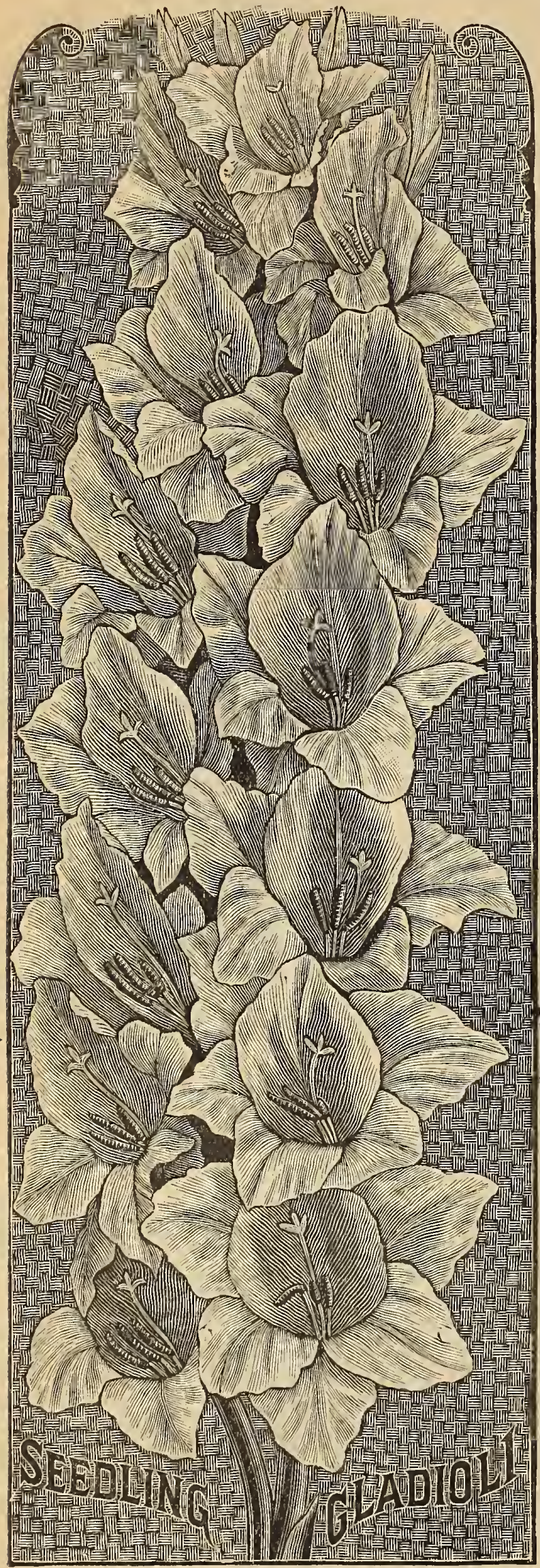

\section{GLADIOLI.}

As stated above, we consider the Gladiolus the most satisfactory of all he summer flowering bulbs, for not only are they the most brilliant and spikes of gorgeous bloom comprise in color all shades from pure white, yellow, orange, cherry, lilac, brilliant scarlet, striped and blotched, and some have the edges of the petals penciled like a fine picotee pink. The individand from 18 to 25 flowers grow on a single spike. The lowest flower on the spike opens first, and when in full bloom, from six to ten are expanded at a time. As soon as the first two flowers are open, the spike may be cut and placed in water where it will bloom for ten days or more, until the last
flower expands. Their culture is of the simplest, as they will grow in any ood garden soil. The popularity of the Gladiolus has now reached such a height that there are in this country and Europe, several growers devoting each a number of acres or land to thelr exclusive production, their list of ly listed some of the newer and more fashionable introductions in separate colors but inasmuch as they are much more expensive, and our space does not permit of a large list, and too, as the trade a ppear justly satisfied with iolus Bulbs and offer them at prices that will prove very attractive. This mixture includes nearly every color, marking and shade inıaginable, embricing the most fashionable strains, and will satisfy, we know, the most Gladioli it may be well to sta te that the bulbs may be planted from A pril until the middle of June. They should be set 4 inches deep and eight or ten inches apart. For a long succession of bloom, plant at intervals of ten or in a dry place, away from frost, during the winter. The numerous little bulblets that will be found at the base of the bulb can be removed, and also planted in the spring. They will bloom and form large bulbs the second superb miyed Gladioli the stock can be rapialy increased, Price for our By exp. or frgt. purchaser paying charges; hundred $\$ 1.25$; thousand, $\$ 10.00$.

GLADIOLUS SEED. One of the most interesting branches of Gladiolus culture is the growing of bulbs from the seed. No skill or special care is required, and in the course of two to three years flowering bulbs will be a fine stock of bulbs, but there is almost sure to be found new sorts that other way. Our seed is from the finest flowers and embrace hundreds of markings and colors. Gladiolus seed, per pkt., $10 \mathrm{cts}$.; $0 z . .25$ cts., postpaid.

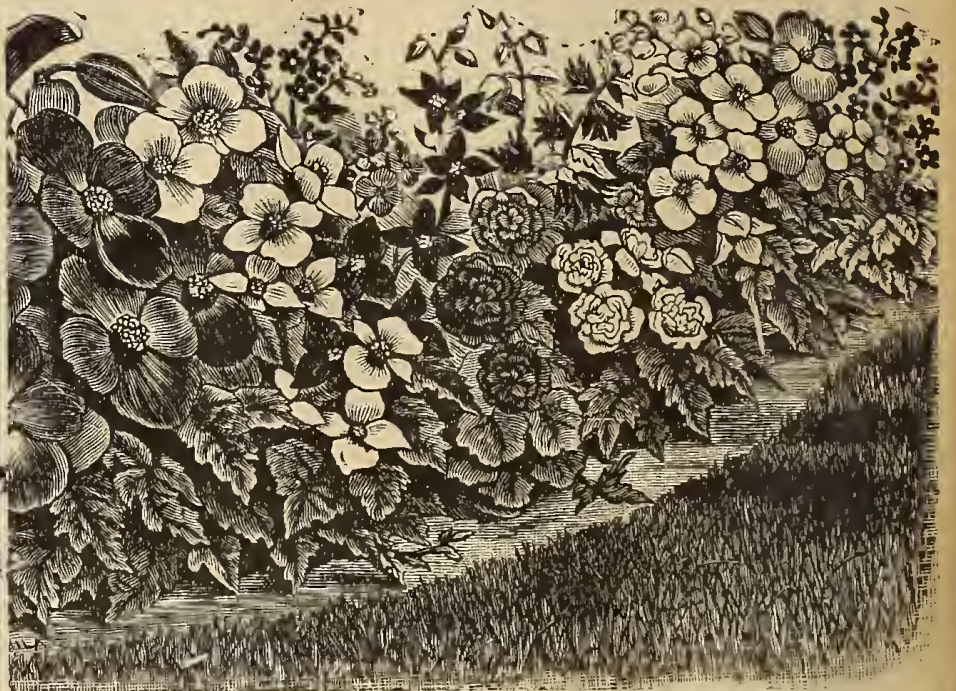

TUBEROUS-ROOTED BEGONIAS. For bedding and pot plants, the Tuberous-Rooted Begonias are among the handsomest of our ummer-fiowering bulbs. They ar Goraniums, have as fine a range of color, and will bloom continuously throughout the summer, even when Geraniums droop through lack or moisture and rail to unfold the Geraniums with their rich and varied colors, ranging from the most delicate shade of yellow and

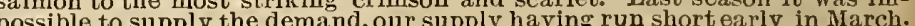
We have this year a large and magnificent collection, composed only of the new large flowering sorts, and trust we shall be able to fill aink, white yellow; $15 \mathrm{cts}$. each, or $\$ 1.50$ per dozen, postpaid; double finest mixed, 25 yellow; $15 \mathrm{cts}$. each, or $\$ 1.50$ per
tts. each; seed, $15 \mathrm{cts}$. per packet.

Clyde Dean, Portland, N. I. writes:

The Aster seed we bought of you proved a brilliant success as to number and quality of plants and flowers; also the Gladioli collection was a decided success. 

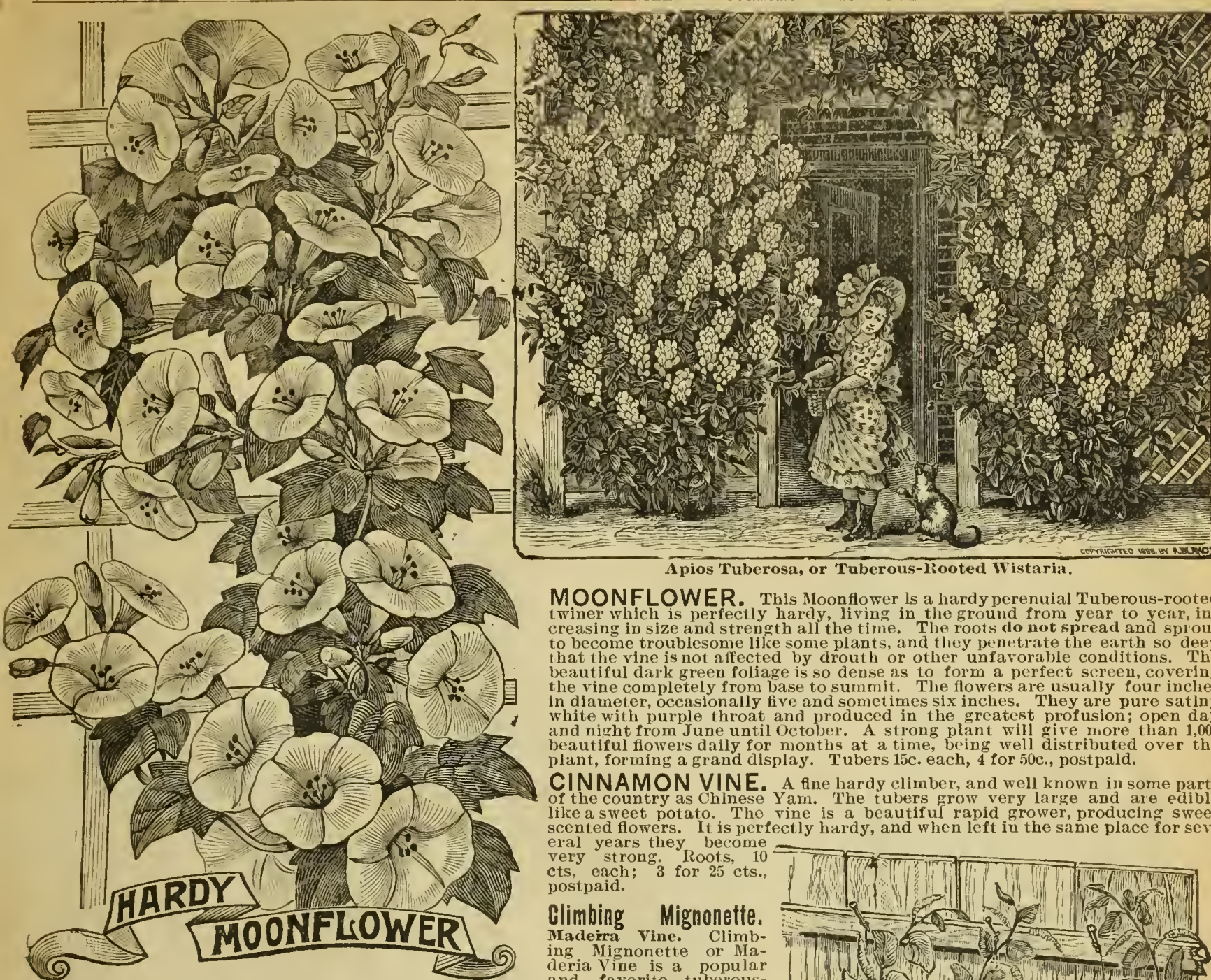

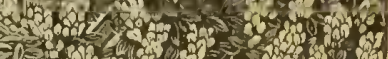

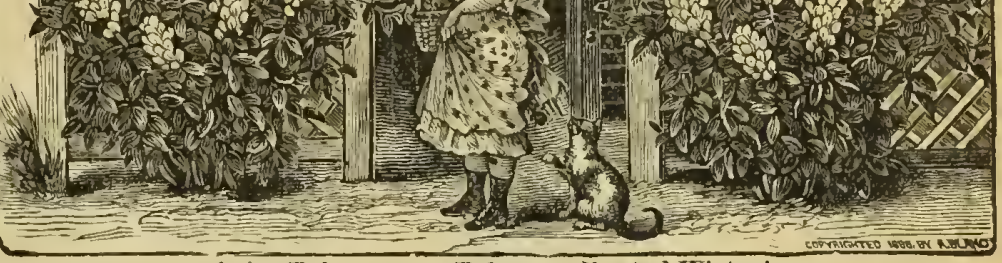

MOONFLOWER.

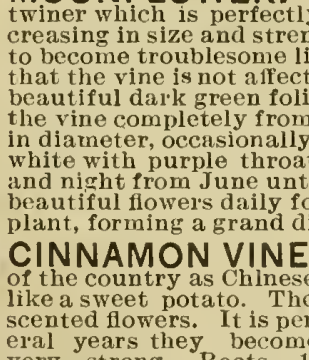

cts, each; 3 for 25 cts.,
postpaid.
Climbing Mignonette.

rooted cllmblng plant, witl dense and beautiful climbing foliage, and o rapld browt twlning on strings to a miteat leicht, or forming tarlands int

autuinn it

nonette. It will grow anywh

APIOS TUBEROSA

TUBEROUS-ROOTED WISTARIA. We hav

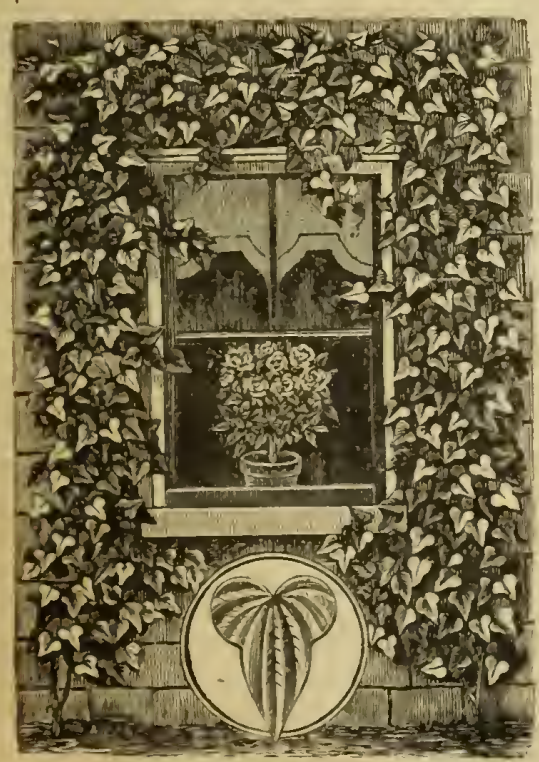

Cinnamor. Vine.

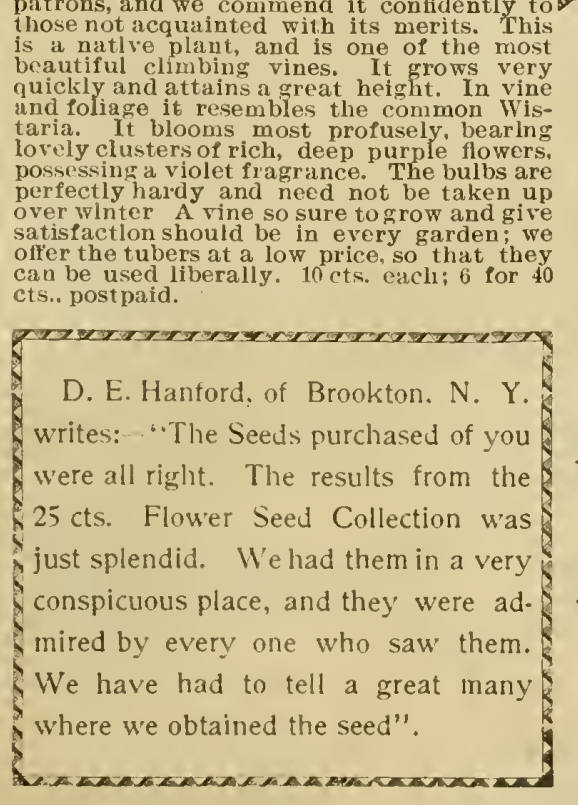

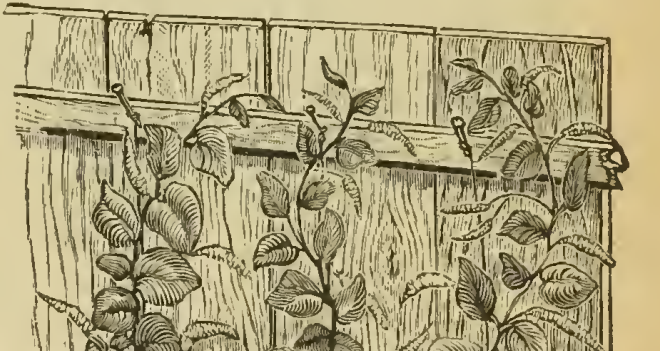

$12=1-1,10$

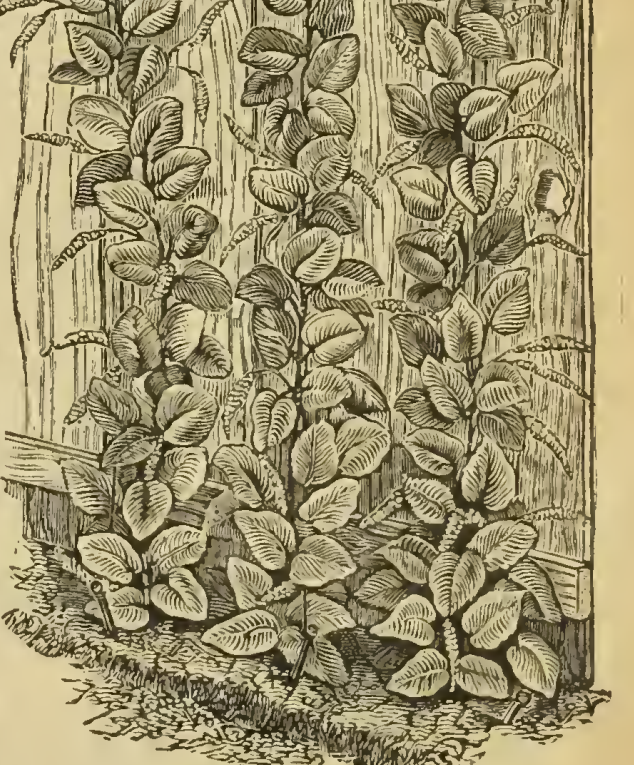

Climblng Mignonette. 


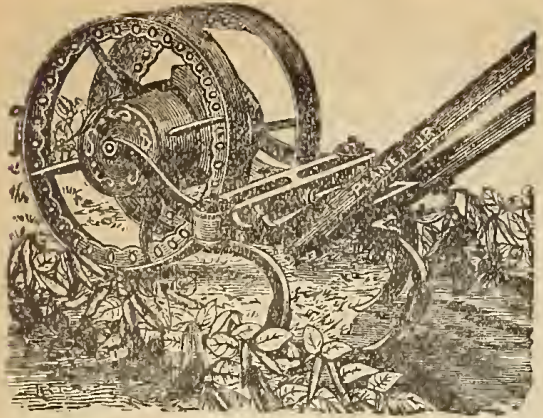

The "Planet Jr" Combined Dxill and Wheel Hoe, as a Cultivator.

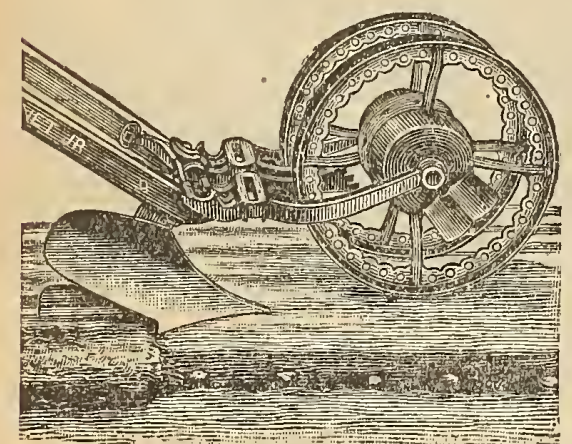

The "Planet Jr." Combined Drill and Wheel

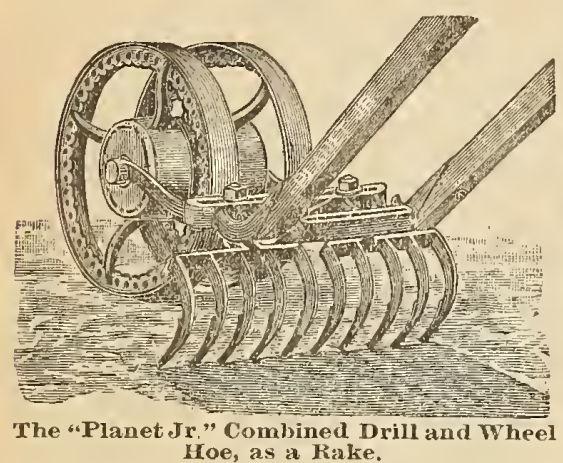

The "Planet Jr." Combined Drill and Wheel

Yoe, as a R.

The Planet Jr. Hill Dropping Garden Drill...

The Planet Jr. Combined Hill Dropping in The Planet Jr. No.2 Drili

The Planet Jr. Combined Drili, Wheel Hoe, oui

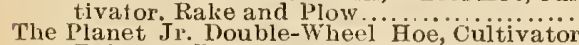
Rake and Plow.

The Planet Jr. Plain Double-ivheel Hoe, no ä The Planet Jr. Single-Wheel Hoe, Cultivator Rake and Plow .....
The Fire-Fiy Hand Plow

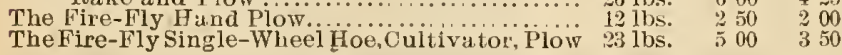

Packed List our

$\begin{array}{rrr}40 \mathrm{lbs} . & 900 \quad 650 \\ 40 \mathrm{lbs} . & 1200 \quad 825\end{array}$

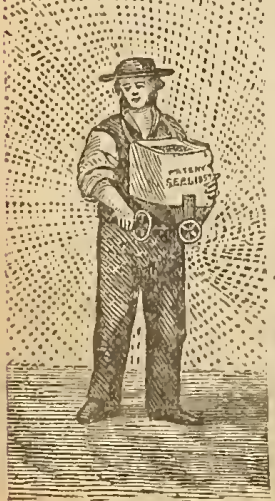

Cahoon seeder.
Cahoon Broadcast Hand Seed Sower. Sows on an average six acres per hour at a with perfect suceess, and do much better as the seed is distributed so much more evenly in hand-sowing. The machine is simple, substantial, not likely to get out of order, and any one can operate it with perfect

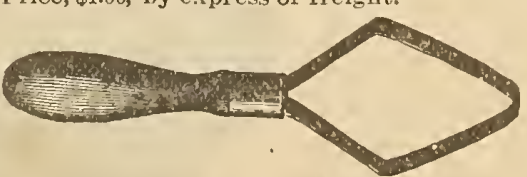

NOYES UAND WEEDER. A convenient, cheap and useful tool, mude of stuel, well tempered. Net price, 25 cents; used to sowing by hand can use this machine by their use, asiving iseffected of four-fith

They are Low, and

To any Railroad either at

MINNEAPOLIS OR CHICAGO.

The "PLANET JR." Tools have atSpace does not admit illustrating and o these Implements, but we wishing further particulars an illustrated catalogue of the "Planet Jr." Tools, Please note our very low prices, and that we deliver them to any or Express Company in MINNEAPOLIS or CHICAGO with= out charge for boxing or cartage.

\section{PRIOE LIST.}

$60 \mathrm{lbs} . \quad 1800 \quad 1350$

BURLINGTON ROUTE.

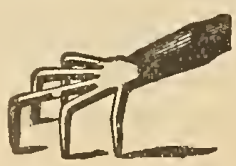

Fxcelsior IIand Weeder. Useful for stirring soil in c. Net price 25 cents; 30

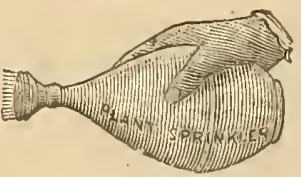

RUBBER SPRINKLER. For sprinkling cut flowlothes, etc. Price, $\$ 1.00$,

The Planet.J1. No.6 All Steel Horse Hoe and Cul- Weight Price Price tivator Combined, with lever wheel....... 70 lbs. \$12 $00 \$ 700$ tive

The Planet Jr. No. 4 All steel Horse Hoe and

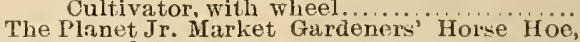

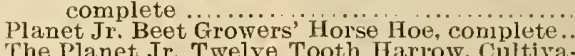
The Planet Jr. Twelve Tooth Harrow, CultivaThe Planet Jr. Furrower, Marker, Hiller and 65 lbs. $1125 \quad 625$ 60 lbs. $\quad 1025 \quad 600$ 75 lbs. $\quad 1250 \quad 800$ $1200 \quad 800$ 70 lbs. $1250 \quad 775$ 5 lbs. $\quad 1600 \quad 1100$

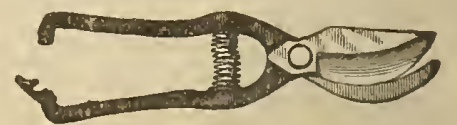

PRUNING SHEARS.-Constructed with powerful druw-cut blade; spiral splings, tion, strong cutting power. l'ostpaid, $\$ 1.00$.

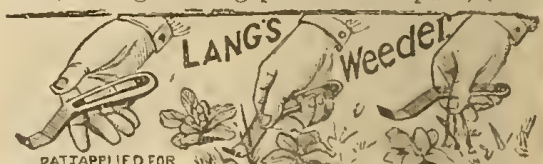

LANG'S WFEDIGR. - This effective weeder is becoming mole populitr each year among tic gardeners, florists, small fruit growers and amateurs. It is vely convenientily used, and are entirely free for use whenever necessary.
Net price, 25 cents; postpaid for 30 cents. 


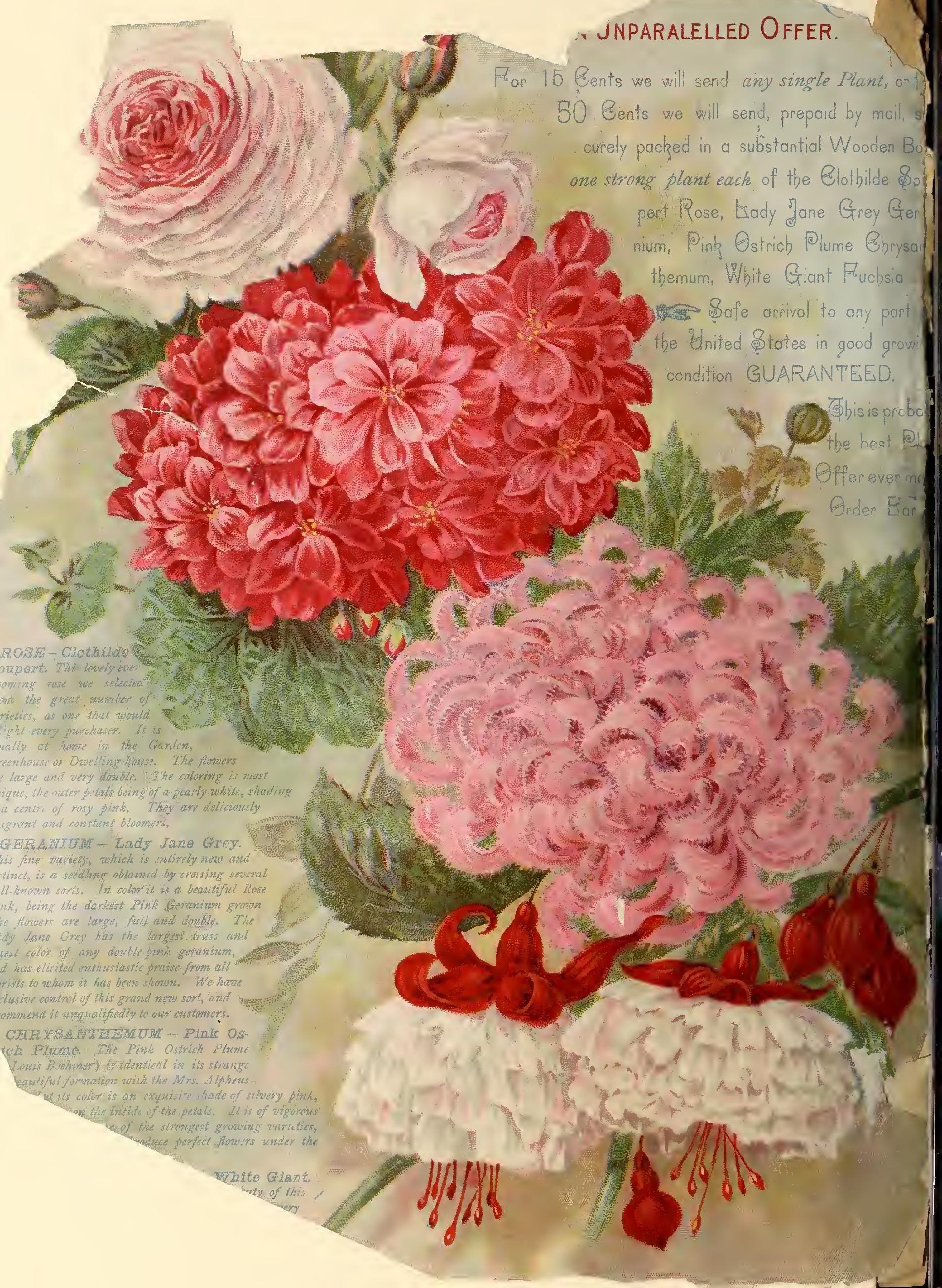

